UICH SCHOOL COURSE IN

LATN COMPOSITION

\title{
BAKER AND INGLIS
}



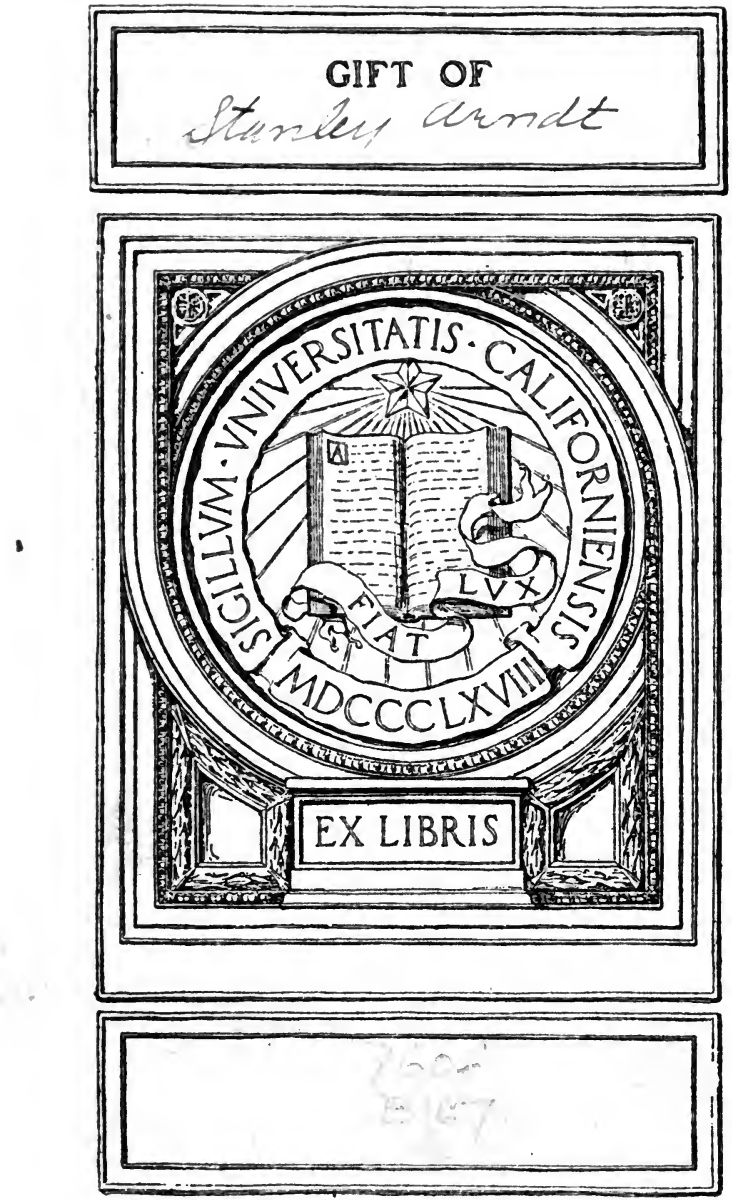



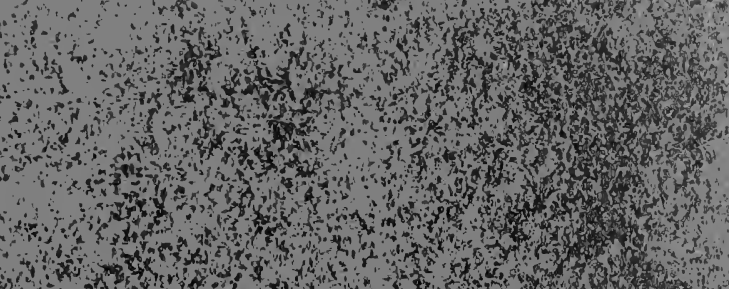

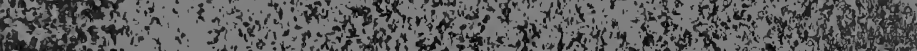

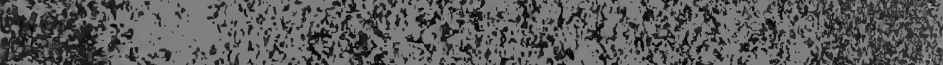

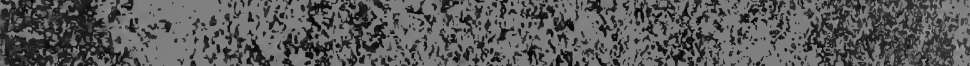

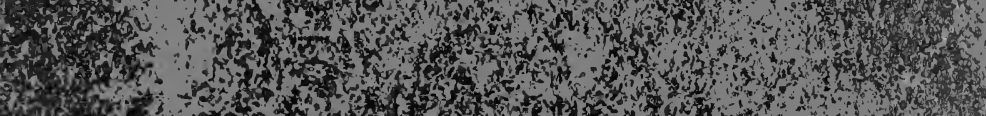

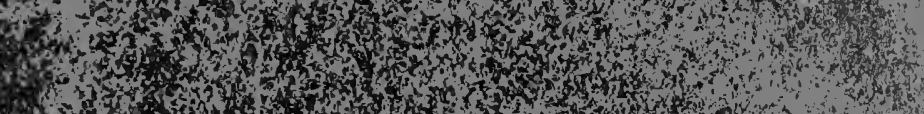

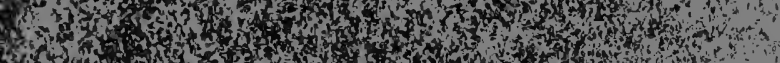

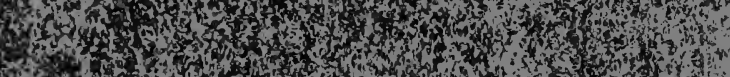
30.

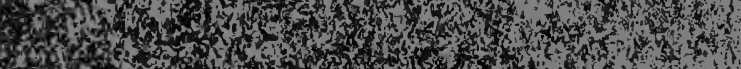

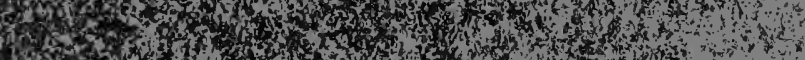

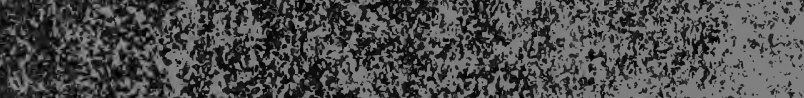

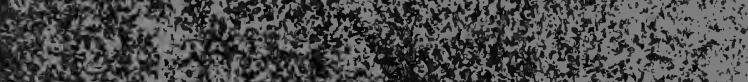
and

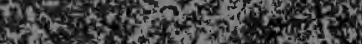

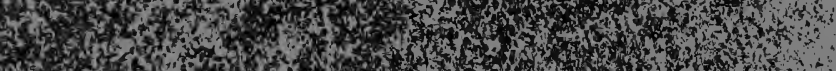




\section{HIGH SCHOOL COURSE IN LATIN COMPOSITION}




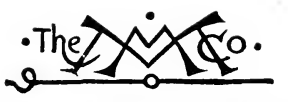

THE MACMILLAN COMPANY NEW YORK - BOSTON - CHICAGO ATLANTA - SAN FRANCISCO

MACMILLAN \& CO., Limited

LONDON - BOMBAY - CALCUTTA MELBOURNE

THE MACMILLAN CO. OF CANADA, LTd. TORONTO 


\section{HIGH SCHOOL COURSE}

IN

\section{LATIN COMPOSITION}

BY

CHARLES MCCOY BAKER

HORACE MANN HIGH SCHOOL, TEACHERS COLLEGE

AND

ALEXANDER JAMES INGLIS

HORACE MANN HIGH SCHOOL, TEACHERS COLLEGE

Yow 垃ark

THE MACMILLAN COMPANY

1909 


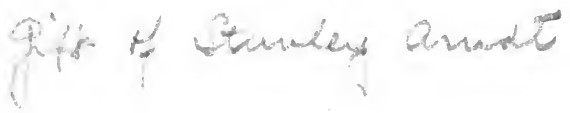

Copyright, 1909,

BY THE MACMILLAN COMPANY.

Set up and electrotyped. Published January, rgog.

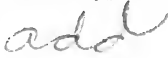

Norwood 租ress

J. S. Cushing Co. - Berwick \& Smith Co.

Norwood, Mass., U.S.A. 


\section{PREFACE}

The aim of this book is to provide a complete course in writing Latin for school use. The book consists of three parts arranged for practice in writing Latin during the last three years of school, and, in addition, a summary of the Elements of Syntax for reference.

Treatment. - In the lessons syntax is treated systematically by topics. For content and vocabulary the exercises are based on Caesar's Commentaries and on the Orations of Cicero which are usually read in our schools.

Summary of the Elements of Syntax. - The first portion of the book consists of a summary of the Elements of Syntax. This summary contains a statement and explanation of those principles of syntax which are essential for writing Latin in the school, so that in the lessons direct reference may be made to this summary instead of to the confusing mass of information given in the large grammars. References to the grammars are given, however, so that, if desired, they may be used instead of, or in addition to, those given in the summary. The illustrative examples are, for the most part, taken from Caesar or Cicero, that the student may the more easily interpret them.

Part I. - Part I consists of a series of twenty-eight lessons based for content and vocabulary on Caesar's Commentaries, Books I-IV. After Lesson X an attempt has been made in the first half of each exercise to give a 
series of sentences which are more or less connected in thought and narrative, thus avoiding the disadvantages of disconnected sentences.

Part II. - Part II consists of a series of twenty-six lessons based for content and vocabulary on the Orations of Cicero usually read in our schools. Here also an attempt has been made to secure continuity of thought in the successive sentences in the first half of each exercise. The lessons of Part II may be supplemented, if desired, by the exercises in writing connected prose (Lessons XXV-XL) of Part III.

In Parts I and II each lesson consists of: 1. a definite assignment of principles of syntax; 2. a definite special vocabulary; 3 . a series of twenty-four sentences for written translation ; 4. an exercise for oral translation. The exercises for written translation of Parts I and II have been so arranged as to permit the following method of procedure: sentences 1-12 to be assigned for written translation outside of the class; sentences 13-24 for unprepared written work in the classroom. To this end all the principles of grammar of a given lesson are developed in the first twelve sentences and are again developed in the last twelve sentences. Hence no attempt has been made to secure continuity of thought in the last twelve sentences. By this redevelopment in the classroom of the syntactical problems of the lesson the authors believe that better results can be gained and that dishonest work can be discouraged. The oral exercises are designed for rapid drill in syntax, and they may be employed either in anticipation of the written exercises or in review to clinch the main principles developed in the lessons. These exercises will also afford material for a quick general review of several lessons. 
Part III. - Part III is designed for the last year of the school and consists of a series of forty lessons, of which Lessons XXV-XL are entirely devoted to practice in writing connected Latin. Each lesson from I-XXIV consists of: 1. a definite assignment of syntax; 2. a definite special vocabulary; 3 . an exercise for written translation consisting of a series of fifteen sentences developing the assigned principles of grammar and the special vocabulary; 4. a short passage of connected prose; 5. an exercise for oral translation. Part III is intended to review entirely the principles of Parts I and II, to extend the application of those principles, and to afford practice in the writing of connected Latin. The sentences of any given lesson are based for content and vocabulary on a certain portion of Caesar or Cicero, the entire series of lessons giving a complete summary of the content of the portions of those authors usually read in our schools. They are, however, so arranged as not to permit the pupil to turn to any given passage of Latin in the attempt to get material for the sentences.

Vocabulary.-The systematic development of vocabulary has been strangely neglected in the study of Latin in our schools, and in this book an attempt has been made to remedy that defect by the preparation of a special vocabulary for each lesson and by a carefully prepared general vocabulary. The vocabulary employed is based on the analysis of the vocabulary of high school Latin made by Professor Lodge of Teachers College, ${ }^{1}$ and very few words have been admitted that are not found in his selected list, which is developed on the principle of the relative frequency of occurrence of words in the Latin read in

1 "Vocabulary of High School Latin," Gonzalez Lodge, Teachers College, Columbia University, 1907. 
high schools. The words peculiar to Caesar have been introduced and developed in Part I, those peculiar to Cicero in Part II, while the vocabulary of Part III supplements those of Parts I and II. 


\section{TABLE OF CONTENTS}

\section{ELEMENTS OF SYNTAX}

Agreement .

Pronouns

Syntax of Nouns

Nominative Case . $. \quad . \quad . \quad . \quad . \quad . \quad . \quad .10$

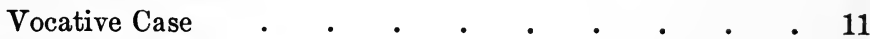

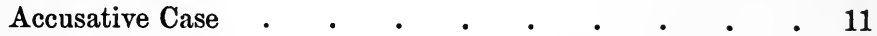

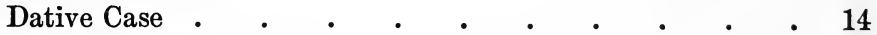

Genitive Case. $\quad . \quad$. $\quad . \quad$. $\quad . \quad$. $\quad . \quad 18$

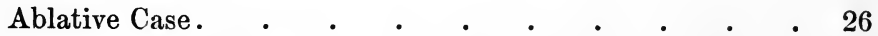

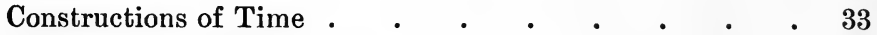

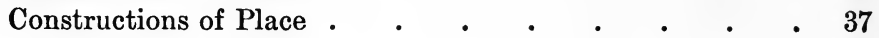

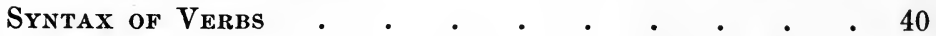

Tenses . . . . . . . . . . . . .

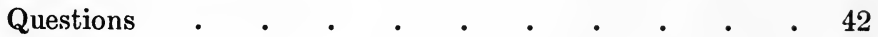

Wishes . . . . . . . . . . . . 44

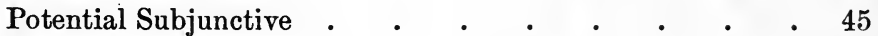

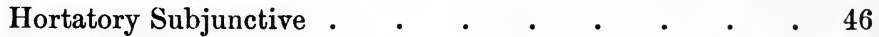

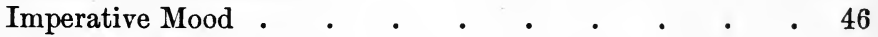

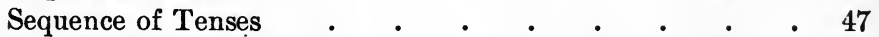

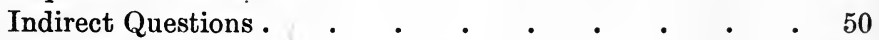

Purpose Clauses . $\quad . \quad$. $\quad . \quad$. $\quad . \quad$. $\quad$. 50

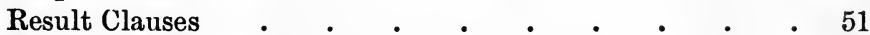

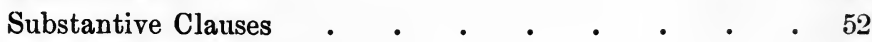

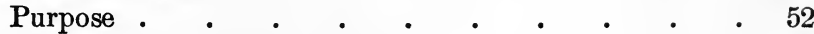

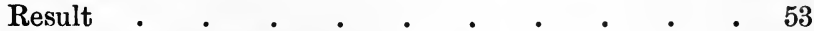

After Verbs of Fearing . $\quad . \quad$. $\quad$. $\quad$. $\quad$. $\quad$. 54

After Verbs of Preventing, etc. . . . . $\quad$. 54

After Verbs of Doubting . $\quad . \quad$. $\quad . \quad$ • 55

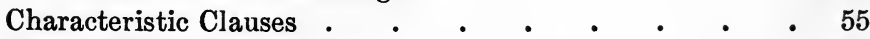

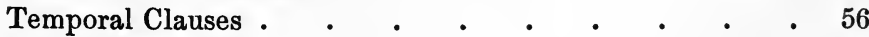

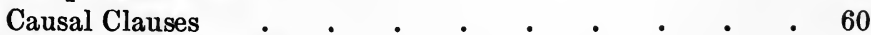

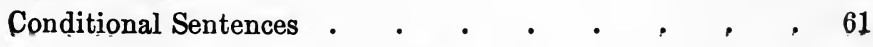




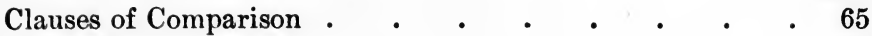

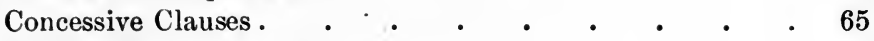

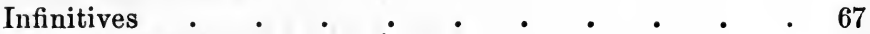

Indirect Discourse . $\quad . \quad$. $\quad . \quad$. $\quad . \quad$. $\quad . \quad 70$

Conditions in Indirect Discourse . $\quad$. $\quad . \quad$. $\quad 73$

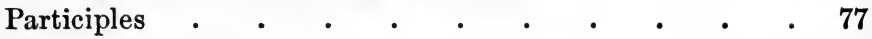

Ablative Absolute . $\quad . \quad$. $\quad . \quad$. $\quad$. $\quad$. 78

Gerund and Gerundive . $\quad . \quad$. $\quad . \quad$. 81

Passive Periphrastic Conjugation . . . . . $\quad$ • 83

Supines . . • • • • • • • • •

Conjunctions .

ORDER OF WORDS .

LESBON

\section{PART I. EXERCISES}

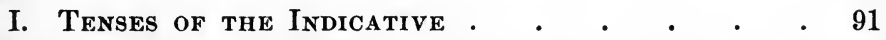

II. Apposition; Predicate Nouns and Adjectives; Verbs of Naming, Choosing, etc. . . . . 93

III. The Ablative Case: Means or Instrument; Agent; Specification; Accompaniment . . . . .

IV. Indirect Ob.ject; Place to Which; Place from Which; Place Where; the Relative. . . 98

V. Expressions of Place; Locative Case . . . 101

VI. Ablative and Genitive of Description; Vocative CASE

VII. Direct Questions; Indirect Questions; Sequence of Tenses . . . . . . . . . .

VIII. Time When; Time within Which; Duration of Time; Extent of.Space . . . . . .

IX. Comparison; Ablative of Comparison; Degree of DifFerence .

X. Adjectives as Substantives; Possessive Adjectives; Personal and Reflexive Pronouns. • 114

XI. Ablative Case: Manner; Cause; Accordance . $\quad 117$

XII. Indirect Discourse: Simple Sentences • $\quad . \quad 120$

XIII. Accusative with Compound Verbs; Inner ObJect 123

XIV. Dative with Special Verbs; Dative with Compound Verbs . . . . . . . . . . 126

XV. Purpose Clauses; Result Clauses . . . . . 129 
LFssoN

XVI. Dative Case: Reference; Purpose.

XVII. Substantive Clauses of Purpose and Result;

INDIRECT REFLEXIVE • • • • • • • 135

XVIII. INFINITIVES $\quad . \quad \cdot \quad \cdot \quad \cdot \quad \cdot \quad \cdot \quad \cdot \quad \cdot 137$

XiX. Partitive Genitive; Partitive Adjectives;

Alius AND Alter . . . . . . . 140

XX. Dative with Adjectives; Genitive with AdJECTIVES • • • • • • • • • • 143

XXI. Gerund; Gerundive; Supine in -um • • 145

XXII. Possessive Genitive; Predicate Genitive; Da-

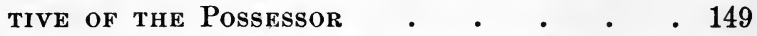

XXIII. Cum-Clauses: Temporal; Causal; Concessive . 151

XXIV. Participles • . • • • • • • . 154

XXV. Ablative Absolute • • : • • . 157

XXVi. Passive Periphrastic . • • • . $\quad$ • 160

XXVII. Complex Sentences in Indirect Discourse 163

XXVIII. Ablative with Uttor, etc.; Review of the Ab-

LAtive CASE . . . . . . • • 166

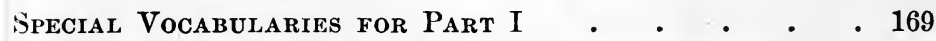

References to Grammars for Part I . . . . . 184

LESSON

\section{PART II. EXERCISES}

I. Questions: Direct and Indirect; Sequence of Tenses; Active Periphrastic . . . . 191

II. Genitive Case; Personal Pronouns; Direct Reflexives . . • • • • • • . . 194

III. Genitive with Verbs • • • • • • 197

IV. Infinitives: Substantive and Complementary $\quad 200$

V. Indirect Discourse: Simple Sentences . • . 202

VI. Indirect Discourse: Complex Sentences • . 205

VII. Conditions: Logical and Ideal. • • • . 208

VIII. Conditions: Unreal . • . . • • . 210

IX. Deliberative Questions; Rhetorical QuesTions; Double Questions . . . . . . 213

X. The Dative Case; Opus est and Ūsus est . . 215

XI. Purpose Clauses: Pure, Relative, and Substantive 218

XII. Result Clauses; Purpose and Result ConTRASTED . 
LEssoN

XIII. Commands; Prohibitions; Exhortations and ENTREATIES . . .

XIV. Characteristic Clauses; Clauses after Verbs of Fearing . . . . . . . . .

XV. Substantive Clauses after Verbs of Preventing, Doubting, etc.; Review of Substantive

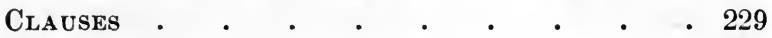

XVI. Wishes; Review of Conditions . . . . . 231 XVII. Conditional Clauses of Comparison; Potential Subunctive . $. \quad . \quad . \quad . \quad . \quad . \quad 234$

XVIII. Gerund; Gerundive; Supine . $\quad$ • . . $\quad$ • 236

XiX. Passive Periphrastic; Ought and Must . . 239

XX. Conditions in Indirect Discourse . • . 242

XXI. Causal Clauses . . . . . . . . . . 245

XXII. Concessive Clauses . . . . . . . . 248

XXIII. Temporal Clauses: Cum; Postquam, etc. • . 251

XXIV. Dum-Claduses; Priusquam and Antequam . 254

XXV. Participles • • • . . • • • • . 257

XXVi. Ablative Absolute • . . . . . . 260

Special Vocabularies for Part II . • • • • . 263

References to Grammars for Part II . $\quad . \quad$. 277

\section{PART III. EXERCISES}

LESSON

I. Pronouns; Adjectives; Agreement . $\quad . \quad 285$

II. Tenses of the Indicative . . . . . 287

III. The Accusative Case $\quad$ - $\quad . \quad$ - $\quad$ - 290

IV. Questions: Direct and Indirect; Sequence of Tenses . . . . . . . . . . 293

V. Purpose and Result Clauses . $\quad$. $\quad$. $\quad$. 296

VI. The Dative Case $\quad . \quad$. $\quad . \quad$. $\quad . \quad$ • 299

ViI. Clauses after Verbs of Fearing, Preventing,

Doubting, etc.; Characteristic Clauses . . 302

ViII. Gerund; Gerundive; Passive Periphrastic ConJugations; Supine . . . . . . . 304

IX. The Genitive Case . . . . • • 307

X. The Genitive Case (continued) . . . . 310

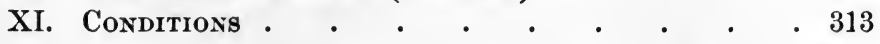


XII. Wishes ; Potential Subjunctive; Conditional Clauses of Comparison . . . . . . 316

XIII. Commands; Entreaties; Prohibitions • 319

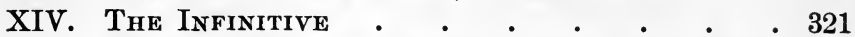

XV. The Infinitive (concluded); Indirect Discourse 324

XVI. The Ablative Case . . . • . . 327

XVII. The Ablative Case (continued) . . . 330

XVIII. Conditions in Indirect Discourse; Dependent Unreal Conditions . . . . . . 333

XIX. Temporal Clauses: Cum-Temporal; Postquam, etc. . . . . . . . . 335

XX. Temporal Clauses (continued): Dum-Clauses;

Priusquam and Antequam; Proviso . . 338

XXI. Participles; Ablative Absolute . . . 341

XXII. Expressions of Place . . . . . . 344

XXIII. Causal and Concessive Clauses • • $\quad$ • 347

XXIV. Expressions and Constructions of Time 350

XXV. Connected Prose . . . . . . . . 352

XXVi. Connected Prose. . . . . . . . 353

XXVII. Connected Prose . . . . . . . . 354

XXVIII. Connected Prose . . . . . . . 355

XXIX. Connected Prose. . . . . . . . . 356

XXX. Connected Prose . . . . . . . 357

XXXI. Connected Prose . . . . . . . . 358

XXXII. Connected Prose . . . . . . . . 359

XXXIII. Connected Prose . . . . . . . 360

XXXIV. Connected Prose. . . . • • . 361

XXXV. Connected Prose . . . . . . . . 362

XXXVI. Connected Prose . . . . . . . . 363

XXXVII. Connected Prose. . . . . . . 365

XXXVIII. Connected Prose . • . . . . . . 366

XXXIX. Connected Prose . . . . . . . . 367

Xl. Connected Prose . . . . . . . 369

Special Vocabularies for Part III . • • • . 371

References to Grammars for Part III • • • 390

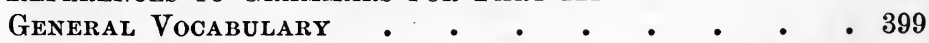

INDEX •. • • . . . • • • • • 451 



\section{HIGH SCHOOL COURSE IN LATIN COMPOSITION}

\section{ELEMENTS OF SYNTAX}

\section{AGREEMENT}

1. Adjectives. - When an adjective modifies two or more zouns of different gender, the agreement is as follows :

$a$. An attributive adjective agrees with the nearest noun.

Multae urbēs, oppida, vīīiue, many cities, towns, and villages.

$b$. A predicate adjective is plural, and when the subjects denote :

1. Living beings, the adjective is masculine.

Pater et māter salvī sunt, father and mother are safe.

2. Things, the adjective is neuter.

Urbēs, oppida, vicique $t \bar{u} t a$ sunt, the cities, towns, and villages are safe.

3. Living beings and things, the adjective agrees with the nearest.

Bona, fortūnae, coniugēs, lỉberīque salvī sunt, property, fortunes, wives, and children are safe.

2. An adjective modifying an infinitive or a clause is neuter.

Diffcile est hōc dè omnibus cōnfïrmâre (A. VII, 15), it is difficult to assert this of all.

3. Some adjectives are frequently used as substantives. 
The masculine denotes persons; the neuter, things. Some of the commonest are :

\section{omnēs, all (men), everybody} boni, the good, good people

māiōrēs, ancestors omnia, all (things), everything mali, the bad, bad people

$\rightarrow$ minōrēs, descendants

Likewise demonstrative, possessive, and proper adjectives. E.g.,

\section{nostrī, our (men)}

$\mathrm{hi}$, these (men) mea, my (property)

Rōmānī, the Romans

4. Nouns. - An appositive agrees with the noun with which it is in apposition in case, and, when possible, in gender and number.

Nerviī, gēens Galliae, the Nervii, a people of Gaul.

Gāia, serva, Gaia, a (female) slave.

5. A noun in apposition with two or more nouns is plural. Marius et Valerius, cōnsulēs, Marius and Valerius, the consuls.

6. An appositive is sometimes best translated by a clause of time, cause, etc.

Mihi cōnsulī dēsīgnātō insidiātus es (I Cat. V, 11), you plotted against me (when I was) the consul elect.

7. Predicate Noun. - A predicate noun follows the same rules as an appositive. Cf. 4-6.

Marius et Valerius cōnsulēs fuērunt, Marius and Valerius were consuls.

8. Verbs. - A verb agrees with its subject in number and person. In compound forms of the verb the participle agrees in gender and case.

Auđit cōpiās missāas esse, he hears that troops have been sent.

9. A collective noun regularly takes a verb in the singular; but a plural verb may be employed when the individuals are thought of. 
Multitūdō adest (IV Cat. VII, 16), a great number is present. Multitūdō lapidēs coniciēbant (B. G. II, 6), a great number were throwing stones.

10. Two or more singular subjects usually take a verb in the plural, but when connected by disjunctive conjunctions (aut ... aut, nec ... nec, etc.), or when considered as a whole, the verb is usually singular.

Marius et Valerius cōnsulēs sunt, Marius and Valerius are consuls. Nec pater nec filius vēnit, neither father nor son came.

Senātus populusque Rōmānus hōc iussit, the senate and the Roman people ordered this.

11. When the subjects are of different persons, the verb is regularly plural and the first person is preferred to the second or third, and the second person to the third.

Ego et tū et ille id facièmus, you, he, and I will do this.

Tũ et Märcus id fécistis, you and Marcus did this.

12. Relative Pronouns. - A relative pronoun agrees with its antecedent in gender, number, and person, but its case depends on its construction in its own clause.

Eörum qū̄s misimus (L. M. XXII, 65), of those whom we have sent. vōs quī ìgnōrātis (III Cat. I, 3), you who do not know.

13. When a relative has two or more antecedents it follows the rules for the agreement of the predicate adjective. Cf. $1 b$.

Puer et puella quōs vỉdimus, the boy and girl vohom we saw.

14. A relative usually agrees with an appositive in its own clause rather than with an antecedent of different gender or number.

Rhodanus quod est fiumen Galliae, the Rhone which is a river of Gaul. 
15. When the antecedent is a clause or a phrase, id quod, quod, or quae rēs is used.

Id quod stultissimum, est, certāre cum ūsūrīs (II Cat. VIII, 18), to struggle with the interest, which is very foolish.

\section{PRONOUNS}

16. Personal Pronouns. - The personal pronouns are not expressed as subjects except for emphasis or to avoid ambiguity.

Ego tibi crēdō, $t \bar{u}$ mihi nōn crēdis, I believe you, (but) you do not believe me.

Dīcō $m \bar{e}$ ventūrum esse, $I$ say that I will come.

17. Nostrī and vestrī are regularly used as objective genitives, nostrum and vestrum as partitive genitives.

Habētis ducem memorem vestrī (IV Cat. IX, 19), you have a leader mindful of you.

Ūnus quisque nostrum (I Cat. I, 2), each one of us.

18. The genitive of the personal or reflexive pronoun is never used to denote possession. The possessive adjectives meus, tuus, noster, vester, suus, must be used instead.

Pater meus, my father.

19. Reflexives. - Reflexive pronouns and adjectives are those which refer back to the subject. The reflexive pronouns of the first and second persons are the personal pronouns. The reflexive of the third person is sui. The corresponding possessive adjectives are meus, tuus, noster, vester, suus.

Mè meaque dēđō, I surrender myself and my (property). Té tuaque dèdis, you surrender yourself and your (property). Sē suaque dēdit, he surrenders himself and his (property). Nōs nostraque dēdimus, we surrender ourselvès and our (property). $\boldsymbol{V} \bar{o} \boldsymbol{s}$ vestraque dēditis, you surrender yourselves and your (property). Sé suaque dēdunt, they surrender themselves and their (property).

20. Pronouns of the Third Person. - Is, ea, id, is regu- 
larly used for the third personal pronoun when not reflexive. Likewise the possessive adjective suus is reflexive only, and in all other relations the possessive genitive of is is regularly employed; èius; his, her, its; eōrum (m. and n.), eārum (f.), their.

Filium suum sēcum dūxit, he took his (own) son with him. Fīilum èeius nōbissum dūximus, we took his son with us.

$\boldsymbol{S} \bar{e}$ dēfendit, he defends himself. Eum dēfendunt, they defend him. In sū̄s fin̄is sē cōnferunt, they betake themselves into their country.

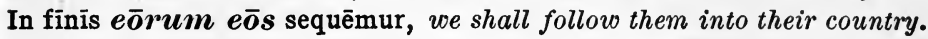

21. Direct and Indirect Reflexives. - In the subordinate clause of a complex sentence the reflexive may be direct or indirect.

22. When referring to the subject of its own clause it is called a "direct reflexive."

Eum ōrāvī ut sē suaque dēfenderet, I besought him to defend himself $\uparrow \quad$ and his (property).

23. When referring to the subject of the main verb it is called an "indirect reflexive." This indirect reflexive can be used only when the subordinate clause expresses the thought of the subject of the main verb and is, therefore, in general confined to clauses in indirect discourse, indirect questions, purpose clauses, after verbs of fearing, doubting, etc., and in subjunctive causal clauses. Otherwise is, ille, or ipse must be used.

Mē ōrāvit, ut se suaque dēfenderem, he besought me to defend him and $\uparrow$ his (property).

24. The reflexive must not be used in a main clause referring to the subject of the subordinate verb.

Quoniam sunt ita multī ut carcer $e \bar{e} s$ capere nōn possit (II Cat. X, 22), since they are so many that the prison cannot hold them. 
25. Ipse is sometimes used instead of a reflexive to avoid ambiguity.

Cūr dē suā virtūte aut dē ipsīus dîligentiā dēspērārent (B. G. I, 40), why should they despair of their own courage or of his care?

26. Reciprocal Pronouns. - The reciprocal relation (one. another, each other, together, etc.) is expressed by inter nōs, inter vōs, inter sè̀.

Hĩ omnēs inter sē differunt (B. G. I, 1), all these differ from each other (among themselves).

Cohortātī inter sēe (B. G. IV, 25), encouraging each other. Inter sē collocūtī (B. G. IV, 30), conferring together.

27. Possessives. - The possessive is frequently omitted when not necessary for clearness.

Filium misi, I have sent my son.

Fīlium tuum mīsī, I have sent your son.

28. The possessive adjectives are regularly used instead of the genitive of the personal and reflexive pronouns to express possession. Cf. 18.

29. Remember that the possessive adjective must agree in gender, number, and case with the noun modified and not with the noun or pronoun to which it refers.

30. Demonstrative Pronouns and Adjectives. - Hic, this, is used of that which is near the speaker in place, time, or thought, and hence is called the demonstrative of the first person.

$\boldsymbol{H} \bar{\imath} \boldsymbol{c}$ locus, this place (the place where the speaker is standing).

31. Iste, that (of yours), is used of that which concerns the person addressed, and hence is called the demonstrative of the second person.

Furor iste tuus (I Cat. I, 1), that madness of yours. 
32. Iste sometimes implies contempt or antagonism.

Sì istīius têla viteèmus (I Cat. I, 2), if we avoid the weapons of that scoundrel.

33. Ille, that, is used of that which is remote from the speaker, and is called the demonstrative of the third person. It is frequently used to denote a change of subject.

Cum illō rêge (L. M. III, 8), with that king.

34. Ille is frequently used to refer to that which is well known or to something or some person just mentioned. Māgnus ille Alexander (A. X, 24), that (famous) Alexander the Great.

35. Ille and hic are sometimes used in contrasts where ille $=$ the former and $\mathrm{hic}=$ the latter.

Caesar et Pompēius māgnī imperātōrēs fuērunt; ille hunc vīcit, Caesar and Pompey were great generals; the former conquered the latter.

36. Is, this, that, is not so definite as hic or ille, and is especially used : (1) to replace the missing third personal pronoun; and (2) as the antecedent of the relative pronoun. E.g., Is quī, a man who.

Eum interfēcērunt, they killed him.

Quị. cênset $\boldsymbol{e} \bar{o} s$ quī haec dēlēre cōnātī sunt (IV. Cat. IV, 7), who recommends that men who have attempted to destroy these (buildings).

37. $\overline{\mathrm{I} d e m}$, the same, frequently represents an English phrase; also, likewise, at the same time, etc.

Dixī ego ìdem (I Cat. III, 7), $I$ also said.

38. Ipse, self, frequently is best translated by even, very, mere, in person, of his own accord, etc.

Ipsī illi philosophī (A. XI, 26), even those (those very) philosophers. Illo ips $\bar{o}$ diè (I Cat. III, 7), on that very day.

Ipse adest, he is present in person.

Ipse id fêcit, he did this of his own accord. 
39. Relative Pronouns and Adjectives. - For the agreement of the relative, ef. 12-15.

40. The relative is never omitted in Latin as it often is . in English.

Epistulam quam scrīpsistī, the letter (which) you wrote.

41. The relative is frequently used for closer connection at the beginning of an independent clause where the English employs a demonstrative.

Quae cum ita sint, since these things are so.

42. A relative clause is sometimes used in Latin to express some other construction in English.

(Is) quĩ aquilam ferēbat (B. G. IV, 25), the standard bearer.

43. Note the correlatives:

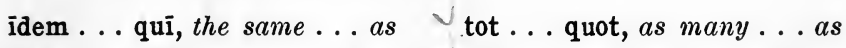
tālis ... quālis, such ...as totiēns ... quotiēns, as often ... as tantus ... quantus, as much ... as

44. Interrogative Pronouns and Adjectives. - Quis, quid, who? what? is the commonest interrogative pronoun. The corresponding adjective is quĩ, quae, quod (declined like the relative). Do not confuse the pronoun and adjective.

Quid vidēs, what do you see? (Pronoun.)

Quod oppidum vidēs, what town do you see? (Adjective.)

45. Uter, utra, utrum, which (of two)? is used only when two persons or things are considered.

Uter cōnsulum, which of the (two) consuls?

Quis civium, which of the citizens? (any number). 
46. Indefinite Pronouns and Adjectives. - The commonest indefinites are :

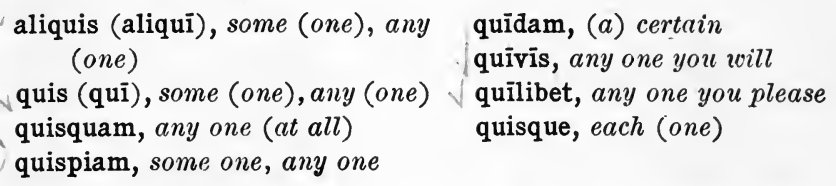

47. Aliquis, aliquid, are the pronoun forms; aliquī, aliqua, aliquod, the adjective forms.
aliquid, anything
aliquod oppidum, any town

48. Quis, quid, are pronoun forms; qui, qua, quod, adjective forms. The indefinite quis is used only after sī, nisi, nē, num, where it replaces aliquis.

Sĩ quis est (II Cat. II, 3), if there is any one.

49. Quisquam, quicquam, has no plural nor separate form for the feminine singular. It is used only in negative sentences or in sentences implying a negative. The corresponding adjective is $\bar{u} l l u s$.

Neque quicquam aliud adsecūtī sunt (L. M. XXIII, 67), nor did they accomplish anything else.

Quisquam dubitābit (L. M. XV, 45), will any one doubt? (implying that no one will doubt).

Neque $\bar{u} l l a$ vis reperiētur (IV Cat. X, 22), nor will any power be found.

50. Quispiam, some one, is rarer than aliquis, but has about the same meaning.

Quaeret quispiam (A. VII, 15), some one will ask.

51. Quīdam, (a) certain, indicates a person not named, but known to the speaker or writer. It is the most definite of all the indefinite pronouns.

Qū̃dam ex militibus (B. G. I, 42), a certain one of the soldiers. 
52. Quivis and quilibet are less common than some of the other indefinites and are used chiefly in affirmative clauses.

Quamvīs fortūnam patī (B. G. II, 31), to endure any fortune whatsoever.

53. Quisque, each, is not often used in the plural and is usually postpositive.

Ūnus quisque nostrum (I Cat I, 2), each one of us.

54. Quisque is frequently used with the superlative and is somewhat idiomatic in that use.

Optimus quisque maximē glōriā dūcitur (A. XI, 26), all good men are greatly influenced by glory; or, more idiomatically, the better a man is, the more he is infuenced by glory.

55. Quisque = each (of several), uterque = each (of two), both.

56. Note the following idiomatic uses of alius and alter :

alius ... alius, one ... another

alii . . . alii, some . . . others

$\left.\begin{array}{l}\text { unus } \\ \text { alter }\end{array}\right\}$... alter, the one... the other (of two)

alius ... aliud, one, one thing ... another, another

alii ... aliam in partem, some in one direction, others in another

Duae fìliae hārum (erant); altera occīsa, altera capta est (B. G. I, 53), there were two daughters of these women; one was killed, the other captured.

\section{SYNTAX OF NOUNS}

\section{Nominative Case}

57. The nominative case is used only as the subject of a finite verb, in apposition with the subject, or as a predicate noun. 
58. The nominative is used of the predicate noun after ome verbs, especially sum and passive verbs of naming, hoosing, etc. Cf. 67-69.

$\begin{array}{lll}\text { sum, be } & \text { fīo, become, be made } & \text { appellor, be called } \\ \text { videor, seem } & \text { creor, be elected } & \text { nōminor, be called } \\ \text { dicor, be said } & \text { habeor, be considered } & \text { maneō, remain }\end{array}$

dēligor, be chosen

Cicerō cōnsul creätus est, Cicero was elected consul.

\section{Vocative Case}

59. The vocative case is used only in addressing a person by name or title. It usually follows one or more words of the sentence.

Quō usque tandem abūtēre, Catilīna, patientiā nostrā (I Cat. I, 1), how long, pray, $(O)$ Catiline, will you abuse our patience?

$a$. The vocative of meus, mea, meum is $\mathrm{mi}, \mathrm{mea}$, meum.

\section{Accusative Case}

60. Direct Object. - Many verbs which in English appear intransitive and require a preposition, are transitive in Latin and take a direct object in the accusative. Some of the commonest are:

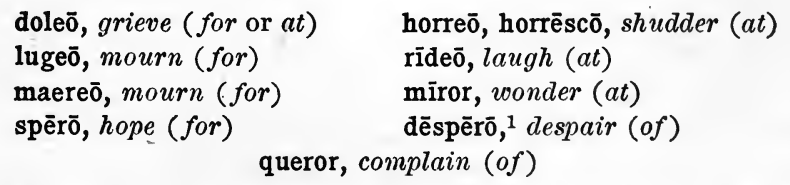

Ariovistī crūudelitātem horrent (B. G. I, 32), they shudder at the cruelty of Ariovistus.

Hon̄̄rēes dēspērant (II Cat. IX, 19), they despair of the honors.

61. Also such verbs as parō, prepare (for); quaerō, search $($ for $)=$ seek; exspectō, wait (for); etc.

Bellum parāre, to prepare (for) var.

${ }^{1}$ Dēspērō sometimes takes dē + ablative. 
62. With Compound Verbs. - Many verbs compounded with circum, trāns, per, praeter, and some with ad, in, and sub, take the accusative.

Flūmen trānsire, to cross the river.

Qui circumstant senātum (I Cat. VIII, 21), who surround the senate.

63. If the simple verb is transitive two accusatives may be found.

Exercitum (trāns) Alūmen trādūcere, to lead the army across the river.

Note. The preposition may be repeated. Cf. preceding example.

64. Cognate Accusative. - An intransitive verb sometimes takes the accusative of a noun which has the same general meaning as the verb. This is called the Cognate Accusative and is usually modified by an adjective.

Bonam vītam vīvere, to live a good life.

Malum somnium somniāre, to dream a bad dream.

65. Inner Object. - A neuter pronoun or adjective is frequently used to define or modify the noun idea implied in the verb.

Eōs hōc monēo (II Cat. IX, 20), I give them this advice (warn them this).

Quī omnia praeclāra atque ēgregia sentiunt (III Cat. II, 5), who entertain all the noble and excellent sentiments (who feel, etc.).

66. Note the phrases:

$\left.\begin{array}{l}\text { Multum } \\ \text { Plüs } \\ \text { Plürimum } \\ \text { Minus } \\ \text { Minimum }\end{array}\right\} \begin{gathered}\text { posse } \\ \text { or } \\ \text { valëre }\end{gathered}\left\{\begin{array}{l}\text { to have great power, to be very powerful, etc. } \\ \text { to have more power, to be more powerful, etc. } \\ \text { to have the most power, to be the most powerful, etc. } \\ \text { to have less power, to be less powerful, etc. } \\ \text { to have the least power, to be the least powerful, etc. }\end{array}\right.$

67. Verbs of naming, choosing, making, showing, appoint- 
i. $g$, and the like may take two accusatives of the same srson or thing.

Q vem Stātōrem nōmināmus (I Cat. XIII, 33), whom we call the Stayer.

68. Some of the most common of these are:

\begin{tabular}{|c|c|}
\hline $\begin{array}{l}\text { appellō, call, } \\
\text { n⿳亠̄minino, name, call } \\
\text { dīcō, appoint, call }\end{array}$ & $\begin{array}{ll}\text { creō, elect, create } & \text { putō, think } \\
\text { faciō, make } & \text { habeō, hold, consider } \\
\text { reddō, make, render } & \text { (passive supplied by fīo })\end{array}$ \\
\hline
\end{tabular}

69. With the passive of these verbs the double nomilative is used. Cf. 58.

70. Verbs of asking, demanding, teaching, and cēlō, conceal, may take two accusatives, one of the person, the other of the thing.

Hōs sententiam rogō (I Cat. IV, 9), I ask these men their opinion. Caesar Aeduōs frūinentum flagitābat (B. G. I, 16), Caesar kept demanding grain of the Aedui.

71. But instead of the accusative of the person, with verbs of asking and demanding, the ablative with a preposition is the common construction.

72. Learn carefully the following verbs with their meanings and constructions:

rogō, ask for, usually takes the accusative of the thing and ab with the ablative of the person. But two accusatives are regularly used when the thing is a neuter pronoun and in the phrase, aliquem sententiam rogāre, to ask any one for his opinion.

petō, ask for, seek, beg, always takes ab + ablative of the person postulo, demand, always takes ab + ablative of the person. pōscō, demand, usually takes ab + ablative of the person. $\bar{o}$ rō, beg, ask for, usually takes ab + ablative of the person. quaerō, $a s k$, inquire, always takes ab, ex, or dē + ablative of the person. doceō, teach and cềō, conceal, take two accusatives, or the accusative of the person and $\overline{d e}+$ ablative of the thing.

Auxilium a Crescure petere (B. G. I, 32), to beg aid of Caesar. Quaesivit $\overline{\boldsymbol{a}}$ Gallis (III Cat. V, 11), he inquired of the Gauls. 
73. Extent. - Extent of space and duration of time. Cf. 169, 199.

74. Extent in degree is expressed by the accusative of neuter pronouns and adjectives. Likewise partem may he so used. Here belong such adverbial accusatives as: nihil, not at all; multum, much, a great deal, etc.

Neque multum frūmentō sed maximam partem lacte et pecore vivunt (B. G. IV, 1), nor do they live much on grain but for the most part on milk and meat.

75. Limit of Motion. - Cf. 188, 190, 194, 195, 198.

76. Subject of an Infinitive. - Cf. $324-325,333 \mathrm{ff}$.

77. Exclamations. - The accusative is sometimes used in exclamations.

$\overline{0}$ fortūnātam rem pūblicam (II Cat. IV, 7), O fortunate republic!

\section{Dative Case}

78. Indirect Object. - The indirect object is put in the dative case.

Tibi librum dedi, $I$ gave the book to you, I gave you the book.

a. Some verbs, especially dōnō, present, and circumdō, surround, place around, take: (1) a direct object and an indirect object; or (2) a direct object and an ablative of means.

Praedam mīlitibus dōnat (B. G. VII, 11), he presents the booty to the soldiers.

Mìlitēs praedā dōnat, he presents the soldiers with the booty.

Castris valllum circumdat, he places a rampart around the camp. Cf. 83.

Castra valle $\overline{\boldsymbol{a}}$ circumdat, he surrounds the camp with a rampart.

79. Dative with Special Verbs. - The dative of the in- 
(irect object is used with most verbs and expressions $\therefore$ gnifying favor, help, please, trust, believe, persuade, coml and, obey, serve, resist, envy, threaten, pardon, spare, inculge, and the like.

80. Some of the most common of these verbs are :

\begin{tabular}{|c|c|}
\hline $\begin{array}{l}\text { faveō, favor } \\
\text { studē̄, desire } \\
\text { crēdō, believe } \\
\text { cōnsulō, consult for }{ }^{1} \\
\text { cēdō, concēdō, yield } \\
\text { imperō, command, order } \\
\text { minor, threaten } \\
\text { minitor, threaten } \\
\text { fīdō, trust } \\
\text { cōnfīdō, trust } \\
\text { diffídō, distrust }\end{array}$ & $\begin{array}{l}\text { persuādē̄, persuade } \\
\text { noceō, harm } \\
\text { parcō, spare } \\
\text { indulgeō, indulge } \\
\text { ìn̄scor, be angry at } \\
\text { pārēo, obey } \\
\text { serviō, serve } \\
\text { invideō, envy } \\
\text { resistō, resist } \\
\text { placeō, please } \\
\text { ignōscō, pardon }\end{array}$ \\
\hline
\end{tabular}

Mīlitēs imperātōrī pārent, the soldiers obey the general.

Quibus populus Rōmānus ignōvisset (B. G. I, 45), whom the Roman people had pardoned.

81. The following verbs are common exceptions to the rule in $79-80$, and take the accusative case :

iubeō, order, command dēlectō,please iuvō, adiuvō, help

Fortīs fortūna adiuvat, fortune favor's the brave.

82. In the passive of the verbs mentioned in 79-80 the verb must be used impersonally, the dative of the indirect object being retained, and the subject of the active becoming an ablative of agent or means.

Aст. Mihi persuādet, he is persuading me.

Pass. Mihi ab ē persuādētur, I am being persuaded by him (it is being persuaded to me by him).

Acr. Hae rês patriae nocent, these things harm the country.

Pass. Patriae his rēebus nocētur, the country is harmed by these things (it is harmed to the country by these things).

1 With the accusative cōnsulo $=I$ ask the advice of, $I$ consull. 
83. Dative with Compound Verbs. - The dative of the indirect object is used with many verbs compounded with ad, ante, con, in, inter, ob, post, prae, prō, sub, super, and sometimes circum.

Quī huic urbī praesident (IV Cat. II, 3), who guard this city.

Bellum hostibus inferre, to make var on the enemy.

84. When the verbs mentioned in 83 are transitive in Latin, a direct object in the accusative may also be found. Lègātum legī̄oñ praefēcit, he put a lieutenant in charge of the legion.

85. Dative of the Possessor. - The dative is used with esse and deesse to denote the possessor, the thing possessed being the subject.

Urb $\bar{\imath}$ satis praesidi est, the city has sufficient protection (to the city is sufficient protection $)=$ Urbs satis praesidi habet.

86. The dative of the possessor is used in a statement of possession, and is regularly equivalent to a construction with habeō. The genitive of possession shows incidentally the possessor. Note carefully the difference.

Gen. The boy's horse is black, Pueri equus est niger.

Dıт. The boy has a black horse, $\left\{\begin{array}{l}\text { Puerō equus niger est. } \\ \text { Puer equum nigrum habet. }\end{array}\right.$

87. Dative of Reference or Interest. - The dative is employed to denote the person interested.

Quid sibi vellet (B. G. I, 44), what did he want (for himself)?

Quibus locus sēdèsque parārentur (B. G. I, 31), for whom a place and dwellings were being prepared.

Tibi extorta est ista sīca dè manibus (I Cat. VI, 16), that dagger has been wrested from your hands (from the hands for you).

88. Dative of Agent. - The dative is regularly used 
with the passive periphrastic conjugation to denote the 1) 'rson upon whom the obligation rests. Cf. 384, 388.

Tibi id faciendum est, you must do this.

89. When the employment of the dative of agent would 1) ing two datives together in such a way as to cause : nbiguity the ablative of agent is used instead.

Q dibus est $\overline{\boldsymbol{a}} \boldsymbol{v} \overline{\boldsymbol{o}} b \bar{\imath} s$ cōnsulendum (L. M. II, 6), for whom you must consult.

90. Dative of Purpose or Service. - The dative may be used to denote that for which something serves.

Nostrī hunc locum castrīs dēlēgerant (B. G. II, 18), our men had chosen this place for a camp.

91. Frequently a dative of reference or interest accompanies the dative of purpose, forming a construction called "the double dative."

Gallīs māgnō impedīmentō erat (B. G. I, 25), it vaas a great hindrance to the Gauls.

92. Dative with Adjectives. - Many adjectives of nearness, fitness, likeness, friendliness, and their opposites take the dative. Some of the most common are:

Fitness :

idōneus, suitable for

aptus, suitable for

accommodātus, suited to

ūtilis, useful to

inūtilis, useless

Likeness :

similis, like

dissimilis, unlike

pār, equal to

aequus, equal to

iniquus, unequal to
Nearness :

proximus, next to, nearest

fīnitimus, neighboring to.

Friendliness, etc.:

amicus, friendly

inimicus, unfriendly, hostile

cārus, dear

infēstus, hostile to

grātus, pleasing

adversus, opposed to, facing

contrārius, opposed to, opposite

Castrīs idōneum locum dēlēgit (B. G. I, 49), he chose a place suitable for a camp.

Helvêtiès erat amicus (B. G. I, 9), he was friendly to the Helvetians. 
93. Aptus, accommodātus, ūtilis, and inūtilis commonly take ad with the accusative.

Ad pūgnam inūtilēs (B. G. II, 16), useless for battle.

Compare: Inūtilēs bellō (B. G. VII, 78), useless for war

94. Proprior and proximus sometimes take the accusative. Proximī Rhènum (B. G. I, 54), nearest the Rhine.

95. Many of these adjectives are sometimes used as substantives and are then construed with the genitive. So, especially, fīnitimi, neighbors; amīcus, friend; inimīcus, (a personal) enemy.

96. Similis usually takes the genitive of persons and regularly takes the genitive of personal pronouns and vērum.

Nèmōo tam tū̄ similis (I Cat. II, 5), no one so like you.

Catilīnae (Gen.) similēs, "the likes of Catiline," those like Catiline.

\section{Genitive Case}

97. Genitive of Possession. - The genitive of possession denotes the person to whom anything belongs or from whom it originates.

\section{Pueri equus, the boy's horse.}

Ōrātiōnēs Cicerōñis, Cicero's speeches.

98. Instead of the possessive genitive of the personal pronouns the corresponding possessive adjectives are always used. Sometimes other possessive genitives are replaced by derivative adjectives.

Pater meus, my father. Never Pater meī. Cf. 18, 28.

Virtūtēs imperātōriae (L. M. XI, 29), the qualities of a general = Virtūtēs imperātōris.

Ut potius in sū̄s quam in aliēnēs fīnibus dēcertārent (B. G. II, 10), that they might fight it out in their own land rather than in the land of others. 
99. In such expressions as the city of Rome, etc., the atin commonly uses an appositive instead of the genitive. Urbs R̄̄ma, the city (of) Rome.

100. A substantive infinitive or clause is sometimes nodified by a genitive of possession or a possessive adjecive.

Est igitur hümānitātis vestrae prohibëre (L. M. VII, 18), it is, therefore, (a requirement) of your kindness to protect.

Vestrumn est prōvidēre (III Cat. XII, 27), it is your (duty) to provide.

101. Genitive of Description or Quality. - The genitive is used for description or quality, but only when the noun of description is modified.

Hominēs māgnae virtūtis (B. G. II, 15), men of great bravery. But Fortis vir et sapiēns homō (L. M. VIII, 20), a man of bravery and (a man) of wisdom, a brave and wise man.

102. The genitive of description is regularly used with numerals as a genitive of measure, and in the phrases: èius modi, hūius modì, cūius modì, etc.

Mürus sēdecim pedum (B. G. I, 8), a sixteen-foot wall.

Ëius modì hominēs (L. M. V, 13), such men.

103. The ablative of description (140) is more common than the genitive except under the conditions mentioned in 102. In most cases either the genitive or the ablative may be used.

Vir māgnae virtūtis $=$ Vir $\operatorname{ma} \bar{a} n \bar{a}$ virtūte.

104. Partitive Genitive.- The genitive denoting the whole of which a part is considered is found with the following classes of words :

1. Nouns and pronouns denoting a part, including alius, alter, etc. 
2. Numerals, comparatives, and superlatives.

3. Neuter pronouns and adjectives when used as nouns.

4. Adverbs of quantity and place.

Pars urbis, $a$ part of the city.

Quārum ūnam (B. G. I, 1), one of which.

Plūs fïrmāmentī (L. M. IV, 10), more strength.

Hōrum fortissimĩ sunt Belgae (B. G. I, 1), of these the bravest' are the Belyians.

Quid mali aut sceleris (II Cat. IV, 7), what (of) evil or crime?

Ubinam gentium (I Cat. IV, 9), where in the world (= in what part of the world)?

105. The partitive genitive is especially common with the following :

multum, much tantum, so (as) much paulum, a little quid, what? plūs, more quantum, how (as) much minus, less aliquid, any (thing) satis, enough, sufficient nihil, nothing, no minimum, least quid, any (thing)

106. With cardinal numerals (especially ūnus), and with some other words, especially quidam and aliquis, the ablative with dē or ex is commonly used instead of the partitive genitive.

$\overline{\text { Ūnus }} \bar{e}$ fïliīs (B. G. I, 26), one of (his) sons.

Quidam ex militibus (B. G. I, 42), a certain one of the soldiers.

Pauci dè nostrìs (B. G. I, 15), a few of our men.

107. When the whole and not a part is considered, the partitive genitive must not be used.

Nōs omnēs, all of us, we all. Haec omnia, all (of) these things.

Id omne (L. M. XXIV, 71), all (of) that.

108. Some words, which in English are used as nouns with a partitive genitive, in Latin are employed as adjec- 
ives and agree with the noun. Some of the commonest of these are:

summus, the top of primus, the first part of medius, the middie of imus (infimus), the battom of extrēmus, the end of reliquus, the rest of

In colle medio (B. G. 1, 24), halfway up the hill (on the middle of the hill).

In summo colle (B. G. II, 20), on the top of the hill.

Extrēmā hieme . . mediā aestāte (L. M. XII, 35), at the end of the winter . . in the middle of sunmer.

Prima nocte (B. G. I, 27), during the first part of the night.

109. Predicate Genitive.-A genitive of possession, a possessive adjective, or a genitive of description may be used in the predicate.

Illae omnēs dissēnsiōnēs èius modī fuērunt (III Cat. X, 25), all those quarrels were such ...

Neque suum iūdicium sed imperātōris esse exīstimāvisse (B. G. I, 41), and (they said) they did not consider the decision theirs, but the general's.

110. Objective Genitive. - Note the connection of thought in the following:

Patriam amat, he loves his native land.

Amor patriae, love of his native land, patriotism.

Amantissimus patriae, very fond of his native land, patriotic.

Rēgnum cupit, he desires power.

Rēgnī cupiditās (B. G. I, 2), desire for power.

Rēgnī cupidus; desirous of power.

It will be noted that the direct object of the verb becomes a genitive when dependent on the cognate noun or adjective. The objective genitive is used of the person or thing toward which an action or feeling is directed. 
111. Objective Genitive with Nouns. - Nouns of action, agency, or feeling take the genitive case.

Amor rē püblicae (IV Cat. VII, 15), love of the state, patriotism. Évocător servōorum (I Cat. XI, 27), the summoner of slaves.

Patientia famis (I Cat. X, 26), endurance of hunger.

112. Sometimes a preposition, usually in or ergā, is used instead of the objective genitive.

Ergā v̄os amor (III Cat. I, 1), love toward (of) you.

Voluntās in sē (B. G. I, 19), good will toward him.

Voluntās $\operatorname{erg} \bar{a}$ me (IV Cat. I, 1), good will toward me.

113. Genitive with Adjectives. - Adjectives of desire, knowledge, memory, fullness, power, sharing, and their opposites, together with participles in -ns when used as adjectives, govern the genitive.

114. Some of the commonest are :

avidus, eager, greedy

cupidus, eager, desirous studiōsus, fond of, devoted to cōnscius, conscious, aware peritus, experienced, skilled imperitus, inexperienced, unskilled prūđēns, knowing, skilled memor, mindful, remembering immemor, forgetful, unmindful oblitus, forgetful

plënus, full

inops, destitute potēns, controlling, ruling particeps, sharing, participating socius, associating in, sharing expers, having no part in, free from

Appetentēs glōriae atque avidi laudis (L. M. III, 7), desirous for glory and eager for praise.

Rē̄ mīlitāris peritissimus (B. G. I, 21), well skilled in military affairs. Memorem vestrī, oblïtum suī (IV Cat. IX, 19), mindful of you, forgetful of himself.

Plēnissimum nāvium (L. M. XII, 33), very full of ships.

Amantissimōs rē pūblicae virōs (III Cat. II, 5), very patriotic men. Cf. Quī amāvit ūnicē patriam (III Cat. V, 10).

115. Refertus takes the genitive of persons, but the ablative of things.

Refertō praedōnum marī (L. M. XI, 31), on a sea full of pirates. Referta divitiīs (L. M. XVIII, 55), full of (filled with) riches. 
116. Genitive with Verbs of Memory, etc. - The contruction with verbs of remembering and forgetting is as ollows :

1. Memini, remember, be mindful of, be regarded of, akes the genitive.

Meminisse Elissae (Aen. IV, 335), to remember Elissa.

2. Memini, remember, keep in mind, recall, takes the iccusative, especially of neuter pronouns and adjectives.

Haec ōlim meminisse iuvābit (Aen. I, 203), some time it will give us pleasure to recall these things.

Praeterita meminisse (L. M. XVI, 47), to recall the past.

3. Reminisscor follows the same rules as memini, but is less common.

Reminīscerētur et veteris incommod̄̄ populī Rōmānī et prīstinae virtūtis Helvêtiōrum (B. G. I, 13), let him remember the former disaster of the Roman people and the previous valor of the Helvetians.

4. Recordor, recollect, recall, regularly takes the accusative of things and de with the ablative of persons.

Recordāminī omnīs dissēensiōnēes (III Cat. X, 24), recall all the quarrels.

$\bar{D} \bar{e} t \bar{e}$ recordor, $I$ remember about you.

5. Obliviscor, forget, usually takes the genitive, but of neuter pronouns and adjectives the accusative is regularly used.

Oblīisiscere caedis atque incendiōrum (I Cat. III, 6), forget slaughter and conflagrations.

Haec oblitus eram, I had forgotten those things.

117. Genitive with Verbs of Reminding. - Admoneō, commoneō, and commonefaciō sometimes take the genitive of the thing, but more commonly de with the ablative. The person reminded is put in the accusative. Moneō 
regularly takes dē with the ablative. With all of these verbs a neuter pronoun is used as an inner object. Cf. 65 .

Dē $\boldsymbol{q u} \bar{o}$ vōs admonuī (L. M. XV, 45), of which I reminded you.

Eōs hōc moneō (II Cat. IX, 20), I give them this advice.

118. Genitive with Verbs of Emotion. - The following impersonal verbs take the accusative of the person who feels, and the genitive of the object or cause of that feeling :

miseret, it pities

pudet, it shames

paenitet, it repents taedet, it tires, it disgusts

piget, it irks, it tires

pertaesum est, it tires

Mēe mē̄mem cōnsiliōrum nunquam paenitēbit (IV Cat. X, 20), $I$ shall never repent my plans (it will never repent me of my plans). $\boldsymbol{M} \overline{\boldsymbol{e}} \overline{\boldsymbol{e}} \boldsymbol{i u s}$ miseret, I pity him (it pities me of him).

119. An infinitive or substantive clause or a neuter pronoun may be used as the subject of these verbs.

Nōn pudēbat magistrātūs in hunc locum escendere (L. M. XVIII, 55), the officers were not ashamed to ascend to this place.

120. Misereor, pity, takes the genitive ; miseror and commiseror, the accusative.

Miserēre sorōris (Aen. IV, 435), have pity on your sister.

Sortem miserātus iñ̄guam (Aen. VI, 332), having pity on his unjust lot.

121. Genitive with Verbs of Accusing, etc. - Verbs of accusing, convicting, condemning, take the genitive of the charge or penalty.

Eum prōditiōnis accūsāvit, he accused him of treason.

Më inertiae nequitiaeque condemnō (I Cat. II, '4), I condemn myself for my inactivity and inefficiency.

a. Such verbs are : accūsō, accuse; 'damnō and condemnō, condemn.

122. Genitive of Indefinite Value. - Verbs of rating and 
i uying take the genitive of the indefinite value with the jollowing :

$\begin{array}{lll}\text { māgnī, much } & \text { plūris, more } & \text { plūrimī, maximī, most } \\ \text { parvī, little } & \text { minōris, less } & \text { minimī, least } \\ \text { tantī, so much } & \text { quantī, how much } & \text { nihilī, naught }\end{array}$

The commonest verbs used with this construction are :

$\begin{array}{lll}\text { aestimō, value } & \text { putō, reckon } & \text { habeō, hold, consider } \\ \text { dūcō, consider } & \text { faciō, make } & \text { sum, be (worth) }\end{array}$

Jmnia perīcula parvī esse dūcenda (A.VI, 14), (that) all dangers were to be considered of little importance.

Est mihi tantì (II Cat. VII, 15), it is well worth my while (it is to me of so much importance). Cf. Operae pretium est (IV Cat. VIII, 16), it is worth while.

123. Definite value or price is expressed by the ablative. Cf. 163.

124. Interest, it is to the interest of, takes the genitive of the person. Reefert is seldom used with this construction.

Re $\bar{u} \boldsymbol{p} \bar{u} b l i c a e$ interest (B. G. II, 5), it is to the interest of the state.

a. Instead of the genitive of the personal pronouns, the ablative singular feminine of the corresponding possessive adjective is regularly used with interest and rëfert.

Ego videō quid $m e \bar{a}$ intersit (IV Cat. V, 9), I see what is to my interest.

125. Potior, get possession of, regularly takes the genitive in the expression rērum potirī, become master of the situation. Otherwise the ablative is regularly used. Cf. 165-166.

Rērum potīi volunt (II Cat. IX, 19), they wish to get control of affairs.

But: Oppido potiuntur, they get possession of the town.

126. Causā and gratiā, for the sake of, for the purpose 
of, take the genitive case, which always precedes. This construction expresses purpose (not cause), and is especially common with the gerund or gerundive. Cf. 381 .

Rei frūmentāriae causā (B. G. I, 39), for the sake of the grain supply.

Bellandī causā (B. G. IV, 1), for the purpose of waging war.

\section{The Ablative Case}

127. Means. - The means or instrument of an action is expressed by the ablative without a preposition.

Litterīs certior factus est (B. G. II, 1), he was informed by dispatches. Gladī̄s māgnam partem eōrum interfēcērunt (B. G. II, 23), they killed a large part of them with swords.

128. Agency. - The personal agent with a passive verb is expressed by $\bar{a}$ or $\mathbf{a b}$ with the ablative.

Ab explōrātōribus certior factus est (B. G. I, 21), he was informed by scouts.

129. The ablative of agent is used only of persons or of something personified; the ablative of means is used only of things.

130. The person through whom is expressed by per with the accusative.

Per explōrātōre ess certior factus est (B. G. I, 12), he was informed through scouts.

Per explōrātōè ès cōgnōvit, he learned through scouts.

131. Manner. - Manner is expressed by the ablative with cum, but cum may be omitted if the noun is modified.

Cum dïligentiā, with care, carefully.

Māgnā (cum) diligentiā, with great care, very carefully.

Note. The position of cum is commonly between the adjective and its noun. 
132. The simple ablative of some nouns is regularly used to denote manner, and some of these are used as ıdverbs. Some of the commonest are: cāsū, by chance; dolō, deceitfully; iūre, justly; iniūriā, unjustly; lēge, legally; meritō, deservedly; ōrdine, duly; vī, forcibly; voluntāte, with the consent of; vulgō, commonly.

Merit̄o ac iūre laudantur (III Cat. VI, 14), they aré deservedly and justly praised.

133. Accompaniment. - Accompaniment is expressed by the ablative with cum.

Cum legiōne duodecimā (B. G. III, 1), with the twelfth legion.

Cum is sometimes omitted in military expressions, especially in the phrase, omnibus cōpiīs (B. G. II, 19). But the use of cum is always possible.

134. Words of participation and contention take the ablative of accompaniment.

Cum Germānins contendunt (B. G. I, 1), they contend with the Germans.

135. Cause. - Cause may be expressed by the ablative, with or without a preposition (ab, ex, dē).

Quā rē, wherefore (because of which thing).

Quā dè causā (B. G. I, 1), for which reason, therefore.

Virtūte sua laudātur, he is praised for his bravery.

136. Cause may also be expressed by propter or ob with the accusative.

Quam ob rem, wherefore. $\quad$ Propter hōc, because of this.

137. The ablative of cause is used with the adjectives laetus, glad; frētus, relying on; contentus, content with. Hūmānn̄s cōnnsiliēs frētus (II Cat. XIII, 29), depending. on human plans.

Nostrā caede contentus (I Cat. III, 7), content with our death. 
138. Accordance. - The ablative of accordance is used to denote that in accordance with which anything is done or is true.

Suīs mōribus (B. G. I, 4), in accordance with their customs.

Meā sententiā (L. M. XIX, 58), in ny opinion.

139. The following are some of the commonest words used in this construction. Each requires a modifier:

$\begin{array}{lll}\text { mōre } & \text { iussū } & \text { rogātū } \\ \text { mōribus } & \text { iniussū } & \text { hortātū } \\ \text { cōnsuētūdine } & \text { sententiā } & \text { cōnsiliō }\end{array}$

140. Description (Quality). - The ablative may be used to denote quality or for description when the describing noun is modified. Cf. 101-103.

Hominēs inimīcō anim̄̄ (B. G. I, 7), men of hostile intent.

Summā virtūte adulēscēns (B. G. I, 47), a young man of the greatest valor. But: A man of valor, vir fortis.

141. The ablative is more common than the genitive in this construction except as indicated in 101-103.

142. Specification. - The ablative without a preposition is used to denote that in respect to which something is true.

Helvētiī reliquōs Gallōs virtūte praecēdunt (B. G. I, 1), the Helvetians surpass the rest of the Gauls in bravery.

143. Note the following ablatives of specification which are very common: numerō, in number; nōmine, in name (by name); nātū, in birth (by birth).

144. Do not confuse the ablative of specification with the ablative of description or quality. (140.) 
Mōns māgnus altitūdine, a mountain great in height. (Specifica$\uparrow$ tion.)

Mōns mägn̄a altitūdine (B. G. I, 38), a mountain of great height.

(Description.)

145. Dignus and indignus take an ablative of specifica. tion.

Dignus cōgnitiōne (A. III, 5), worthy of acquaintance.

146. Separation. - Separation is commonly expressed by the ablative with $a b, e x, d \bar{e}$. So always of persons and where actual motion is involved.

Quī prōvinciam ab Helvètiīs dividit (B. G. I, 2), which separates the province from the Helvetians.

Egredere ex urbe (I Cat. V, 10), depart from the city.

147. But many verbs of abstaining, excluding, removing, relieving, etc., together with some compounds of $a b$, ex, and $\mathbf{d e}$, are used either with or without a preposition.

CHostēs $\overline{\boldsymbol{a}} \boldsymbol{p} \overline{\boldsymbol{u}} \boldsymbol{g n} \overline{\boldsymbol{a}}$ prohibēre (B. G. IV, 34), to keepp the enemy from battle.

Eōs $\boldsymbol{p} \bar{u} g n \bar{a}$ prohibēre (B. G. IV, 11), to keep them from battle.

(Proeliō excēdēbant (B. G. III, 4), they were withdrawing from battle. Ex proeliō excēdunt (B. G. IV, 33), they are withdrawing from battle.

148. Some of the commonest verbs which may be used without a preposition are:

abstineō, withhold from

ēgredior, depart from, go out expello, drive out moveō (locō, senātū), move, remove dēsistō, desist from excēdō, go out interclūdō, shut off prohibeō, prevent from, keep from
, release from, free from 
149. The following very commonly take the ablative without a preposition:

lỉberō, free from nūđō, bare prīvo, deprive of spoliō, strip of, rob mē abdicō, resign

And the adjectives:

lỉber, free from nūdus, stripped of $\quad$ vacuus, empty of, free from Ut Ubiōs obsidiōne lïberāret (B. G. IV, 19), that he might free the Boii from a siege.

Ubi mūrus dêfênsōoribus nūdātus est (B. G. II, 6), when the wall had been bared of defenders.

150. Origin. - Particles signifying birth and origin, especially nātus, born of, and ortus, descended from, take the ablative usually without a preposition.

Iove nātus et Māia (Aen. III, 56), the son of Jupiter and Maia.

151. But $a b$ or ex is frequently used of remote ancestors.

Ex Cimbrīs Teutonīsque prōgnātī (B. G. II, 29), descended from the Cimbri and Teutons.

152. Material. - The ablative is used with ex to denote the material.

Scūta ex cortice facta (B. G. II, 33), shields made (out) of bark. Nāvēs factae ex rōbore (B. G. III, 13), boats made (out) of oak.

153. With verbs of plenty and want the ablative is used. So particularly verbs of filling take the ablative of means.

$\boldsymbol{E} \overline{\boldsymbol{a}}$ (sīcā) carēre nōn potes (I Cat. VI, 16), you cannot do without that (dagger).

Multitū uine hostium castra complērī (B. G. II, 24), (that) the canp was filled with a multitude of the enemy. 
154. Egeō and indigeō may also take the genitive. Nê quis auxilī egeat (B. G. VI, 11), that no one might lack aid.

155. Opus est or ussus est, there is need, takes the dative of the person who wants and the ablative of the thing wanted. Neuter pronouns may be used as subjects. Üsus est is much rarer than opus est.

Mihi auxiliō tuō opus est, I need your aid.

Sī 'quid ipsī à Caesare opus esset (B. G. I, 34), if he himself wanted anything from Caesar.

156. Of verbs the infinitive or the ablative singular neuter of the perfect passive participle may be used.

Sì quid opus factō esset (B. G. I, 42), if there should be any need of action.

157. Comparison. - When quam is used after a comparative, the second noun takes the same case as the noun with which it is compared, that is, quam is followed by the same case as precedes it. But when quam would be followed by the nominative or accusative case, it may be omitted. Then the second noun is put in the ablative case. $\left.\begin{array}{l}\text { Hic mōns altior est quam ille, } \\ \text { Hīc mōns altior est illō, }\end{array}\right\}$ this mountain is higher than that.

158. But the ablative cannot replace quam with the genitive, dative, or ablative.

Exercitus Pompēīi māior fuit quam Caesaris, Pompey's army was larger than Caesar's. Here the ablative construction would mean that the army was larger than Caesar !

159. With plūs, minus, amplius, and longius, quam is often omitted without changing the construction.

Cum ipsī nōn amplius octingentōs equitēs habērent (B. G. IV, 12), although they themselves did not have more than eight hundred horsemen. 
160. Degree or Measure of Difference. - With comparatives and words implying comparison, the ablative is used to denote the measure or degree of difference.

Turris tribus pedibus altior est quam mürus, the tower is three feet higher than the wall.

Intellegēes multō mē vigilāre ācrius. (Cat I. IV, 8), you woill realize that I watch much more sharply (more sharply by much).

Mīlibus passuum quattuor et vīgintĩ abesse (B. G. I, 41), was twentyfour miles distant (distant by twenty-four miles).

Paucīs ante diēbus (B. G. I, 18), a few days before (before by a few days).

161. Some of the commonest words thus used are : multō, much; paulō, a little; eō, hōc, this much, so; and words of time and space.

162. Note especially the expressions :

$\left.\begin{array}{l}\text { Quantō ... tantōo } \\ \text { Qūo } \ldots \text { hōc }\end{array}\right\}$ with comparatives, the . . the . . .

$\boldsymbol{Q} u \bar{o}$ māior vīs aquae $\ldots h \bar{h} \bar{c}$ artius te.eērentur (B. G. IV, 17), (so that) the greater the force of the water... the more tightly they were held.

Quantō erat gravior oppūgnātiō, tantō crēbriōrēs litterae mittēbantur (B. G. V, 45), the more severe the siege was, the more numerous were the dispatches sent.

163. Price. - Definite price is expressed by the ablative. Domum sestertium tribus millibus èmit, he bought the house for three thousand sesterces.

164. Remember that indefinite value is expressed by the genitive. Cf. 122.

165. Ablative with $\bar{u} t o r$, etc. - The deponents ütor, fruor, fungor, potior, vēscor, and their compounds take the ablative.

Quō usque tandem abūtēre nostrā patienti $\bar{a}$ (I Cat. I, I), how long, pray, will you abuse our patience? 
166. Potior sometimes takes the genitive, regularly in he phrase, rērum potīin, to become master of the situation. Jf. 125 .

\section{Constructions of Time}

167. Time when is expressed by the ablative case. Diē quartō pervēnērunt (B. G. I, 26), on the fourth day they arrived.

168. Time within which is expressed by the ablative case.

Diēbus quīndecim pervēnit (B. G. II, 2), within fifteen days he arrived.

169. Time how long (extent of time) is expressed by the accusative case.

Dum paucōs diēs morātur (B. G. I, 39), while he delayed for a few days.

170. In some expressions where the English emphasizes the place, the Latin uses the ablative of time.

Omnibus Galliciss belliss (B. G. IV, 20), in all the Gallic wars.

Quỉ bellō Cassiānō dux fuerat (B. G. I, 13), who had been leader in the war with Cassius.

171. About, with words of time, may be expressed by dē.

Dē tertiā vigiliā (B. G. I, 12), about the third watch.

172. Toward, until, with words of time, may be expressed by ad or sub' with the accusative.

Ad multam noctem (B. G. I, 26), until late at night.

Sub vesperum (B. G. II, 33), toward evening.

Ad vesperum (B. G. I, 26), until evening.

173. Ago may be expressed by abhinc with the accusative. Cf. also 174 .

Abhinc multōs annōs, many years ago. 
174. Before and after are expressed by ante and post with an ablative of degree of difference.

Paucis ante annis or paucis annis ante, a fero years before (ago).

Paucis post annis or paucis annis post, a few years after. Also :

\section{Ante paucōs annōs. Post paucōs annōs.}

Note the change of construction when the ante or post precedes.

175. The Roman day was divided into twelve hours (hōrae) between sunrise and sunset. Thus, six to seven A.M. was approximately prima hōra, etc. The night was divided into four watches (vigiliae) of about three hours each, from approximately six P.M. to six A.M. Thus, six to seven P.M. was about prïma vigilia, etc.

176. The Roman Month. - The names of the Roman months are as follows :

Iānuārius, -a, -um ${ }^{1}$ Māius, -a, -um

Februārius, -a, -um Iūnius, -a, -um

Mārtius, -a, -um

Aprīlis, -e
Quintīlis, -e (Iūlius)

Sextīlis, -e (Augustus)
September, -bris, -bre Octōber, -bris, -bre November, -bris, -bre December, -bris, -bre

Previous to 46 B.c., March, May, July, and October had 31 days, February 28, and the others 29. In that year Julius Caesar reformed the calendar, giving each month the number of days which it has at present. Shortly afterward the name for July was changed from Quintilis to Jūlius, and later that of August from Sextilis to Augustus.

177. The Roman month had three separate points from which all other days were reckoned.

${ }^{1}$ The abbreviations are underlined. The names of the months are all adjectives. 
The Calends, Kalendae, the first of the month.

The Nones, Nōnae, the fifth or seventh of the month.

The Ides, İdus, the thirteenth or fifteenth of the month.

In March, May, July, and October, the Nones fell on tre seventh and the Ides on the fifteenth; in all other r conths the Nones on the fifth and the Ides on the thirteenth.

178. From these points all other dates were reckoned hackward, counting the day from which and the day to which the reckoning is made. Thus, two days before the Nones according to our reckoning would be three days before the Nones according to the Roman reckoning.

179. The formulae for expressing Roman dates are:

1. On the Calends, Nones, or Ides - ablative plural. E.g., Nōnīs Septembribus, on the Nones of September (September 5th).

2. On the day before the Calends, Nones, or Ides:

Prīidèe $\left\{\begin{array}{l}\text { Kalendās } \\ \text { Nōnnās } \\ \text { İdūs }\end{array}\right\}$ (Acc. pl. fem. of the name of the month.)

E.g., Prīdiē Īdūs Februāriās, February 12th.

3. For all other dates:

Ante diem (ordinal modifying diem) $\left\{\begin{array}{l}\text { Kalendās } \\ \text { Nōnās } \\ \bar{I} \text { Iūs }\end{array}\right\}$ (Acc. pl. fem. of month.)

E.g., Ante diem quīntum Kalenđās Novembrīs, October $28 t h$.

180. To change English dates into Roman :

1. Between the first of the month and the Nones, or between the Nones and the Ides, add one to the date of the Nones or Ides and subtract the English day of the month. E.g., 
Nov. 2: The Nones of November fall on the 5th. $5+1-2=4$. Ante diem quārtum Nōnās Novembrīs.

Nov. 8 : The Ides of November fall on the 13th. $13+1-8=6$. Ante diem sextum Īdūs Novembrīs.

2. Between the Ides and the Calends, add two to the number of days in the month and subtract the English date. Of course the Calends will be those of the following month. E.g.,

Oct. 28 : In October there are 31 days. $31+2-28=5$.

Ante diem quīntum Kalendās Novembrīs.

181. 'The phrases prīie and ante diem, etc., may be used after a preposition without any change taking place in the phrases. Ex, from; in or usque ad, until.

In ante diem quīntum Kalendās Novembrīs (I Cat. III, 7), until October 28 th.

Ex ante diem tertium Nōnās Iūniās usque ad Prīdie Kalendās Septem- bris, from June $3 d$ until August 31st.

182. The Roman year is commonly expressed by the names of the consuls in the ablative absolute.

M. Messāāā et M. Pìsōne cōnsulibus (B. G. I, 2), (Marcus Messala and Marcus Piso being consuls) in the consulship of Marcus Messala and Marcus Piso, 61, B.C.

183. The year may also be reckoned from the year 753 B.C., the legendary date of the founding of Rome. For any date B.C., subtract the English date from 754; for any date A.D., add the English date to 753. The formula is : Annō urbis conditae (ordinal numeral modifying annō) = A, U. C. 154 в.c. $=$ Annō urbis conditae sēscentēsimō. $\quad 754-154=600$. 47 A.D. = Annō urbis conditae octingentēsimō. $753+47=800$.

184. The year may also be expressed according to the following formulae: 
Annō ante Chrīstum nātum (ordinal numeral modifying annō) $=$ B.c.

Annō Dominī (ordinal numeral modifying annō) $=$ A.D.

63 в.c. = Annō ante Chrīstum nātum sexāgēsimō tertiō.

1900 A.D. = Annō Dominī mīlēsimō nōngentēsimı̄o.

185. Caesar (B. G. I, 6) gives us a complete date as follows:

Is diēs erat ante diem quīntum Kalendās Aprīlīs Lūciō Pīsōne Aulō Gabiniō cōnsulibus, March 27th, 58 B.C. But he abbreviates the date as follows : a. đ. V. Kal. Apr. L. Pìsōne, A. Gabīniō cōnsulibus.

\section{Constructions of Place}

186. Place where is expressed by the ablative with in or some other preposition.

187. Place to which is expressed by the accusative with ad or in.

188. Place from which is expressed by the ablative with $a b$, ex, or dē.

189. Place Where. - Exceptions : locō, locīs, parte, partibus, castrīs, dextrā (parte), sinistrā, laevā, terrā marīque, castrīs, may omit in. Likewise nouns of place when modified by tōtus, cūnctus, or omnis.

Multīs locīs (B. G. III, 21), in many places. Tōtīs castrīs (B. G. I, 39), in the whole camp.

190. Place to Which. - In with the accusative implies actual entrance into a town, city, etc. Ad is more general and may signify general direction toward, to the borders of, etc.

In urbem, into the city (actual entrance implied).

Ad urbem, to the city (actual entrance not necessarily implied).

191. The construction of place-to-which regularly oc- 
curs with verbs of motion; but verbs of placing, pōnō, locō, conlocō, statuō, cōnstitūo, take in with the ablative. Caesar exercitum in hībernīs conlocāvit, Caesar stationed the army in winter quarters.

192. Place from Which. - Note the difference in meaning of the prepositions :
ab, from, away from
$\bar{a}$ flūmine, away from the river
ex, from, out of ex urbe, out of the city
dè, from, down from, away from dē mūrō, down from the wall

For the omission of the preposition with some verbs of abstaining, etc., cf. 147-149.

193. The endings of the locative case are as follows:

$\begin{array}{lll} & \text { SiNG. } & \text { Plur. } \\ \text { DeCL. I } & -a e & -i \bar{s} \\ \text { DeCL. II } & -\overline{1} & -i \bar{s} \\ \text { DeCL. III } & -\overline{1}(-e) & \text {-ibus }\end{array}$

194. With names of towns and small islands and with domus and rūs.

a. Place where is expressed by the locative case.

$b$. Place to which is expressed by the accusative without a preposition.

c. Place from which is expressed by the ablative without a preposition.

$\begin{array}{ll}\text { Rōmae, at Rome } & \text { Pompēīis, at Pompeii } \\ \text { Rōmam, to Rome } & \text { Pompēiōs, to Pompeii } \\ \text { Rōmā, from Rome } & \text { Pompēiīs, from Pompeii } \\ \text { domī, at home } & \text { rūrī, in the country } \\ \text { domum, home } & \text { rūs, into the country } \\ \text { domō, from home } & \text { rūre, from the country }\end{array}$

195. The general words, urbs, oppidum, insula, etc., require a preposition. Compare the following expressions : in urbe, in the city in urbe Rōmā, in the city Rōmae, in Rome of Rome 
in urbem, into the city in urbem Rōmam, into the Rōmam, to Rome city of Rome

ex urbe, out of the city ex urbe Rōmā, out of the Rōmā, from Rome city of Rome

196. The following locatives are also used to express place where:

humi, on the ground foris, out of doors militiae, abroad, in the field of war belli, in war

a. Domī, locative case, may be modified by a possessive adjective in -ae.

domī meae, at my house

197. At the home (house) of may be expressed by apud. Cf. French chez.

Fuistī apud Laecam (I Cat. IV, 9), you were at the house of Laeca.

198. General direction to or from the neighborhood of a city, etc., may be expressed by ad, near, toward, to the neighborhood of, and ab, from the neighborhood of.

Ad Rōmam, near or toward Rome, to the neighborhood of Rome.

$\overline{\mathbf{A}} \mathbf{R o ̄} \mathbf{m} \bar{a}$, from the vicinity of Rome.

199. Extent of Space. - Extent of space is expressed by the accusative case.

Mürus decem pedès altus, $a$ wall sixteen feet high.

The adjectives most commonly used with the accusative of extent of space are: altus, high, deep; lātus, broad, wide; longus, long.

200. Distance may be expressed by the accusative of extent, or, with absum, distō, etc., by the ablative of measure of difference.

Ab hīs castrīs oppidum aberat mīlia passuum octō (B. G. II, 6), the town was eight miles distant from this camp.

$\bar{A}$ nostris mālibus passuum XXIV abesse (B. G. I. 41), were twenty-four miles from our troops. 


\section{SYNTAX OF VERBS}

\section{Tenses}

201. Present Tense. - The present tense is used of actions going on in present time and in statements which are universally true.

202. The present tense modified by iam diū, iam prīdem, iam dūdum, iam multōs annōs, or iam with any expression of duration of time, is used of actions begun in the past but still continuing. In this use the Latin present tense is translated by the English present perfect tense.

Quod tē iam dūdum hortor (I Cat. V, 12), as I for a long time have been urging (and still do urge) you (to do).

203. Imperfect Tense. - The imperfect tense is used to express repeated, continued, or customary acts in past time, or to describe a state of affairs in past time.

Hōc faciēbam, I was doing this, I used to do this.

Hōc cotīdiē faciēbat, every day he did this - used to do this.

204. However, the imperfect tense is not used to express a single completed act merely because duration of time is involved.

Diū pūgnātum est, the battle lasted a long time.

Similarly, expressions containing definite numbers are used with the perfect instead of the imperfect.

Vixit centum annōs, he lived a hundred years.

205. The imperfect tense modified by iam diū, etc. (202), is used of actions begun in the more remote past and continuing into the nearer past. It is translated by the English progressive pluperfect.

Quoniam iam multōs annōs Rōmae habitäbat, since he had now for many years been living at Rome (and still lived there). 
206. Perfect Tense. - The perfect is used of an act which took place at some point in past time.

Diē quārtō pervēnērunt (B. G. I, 26), on the fourth day they arrived.

207. The historical perfect is used in narrative writing and is frequently used side by side with the imperfect and pluperfect; the imperfect and pluperfect describing the circumstances attending the act, while the perfect relates the act itself.

Id (flumen) Helvētiī trānnsībant: . . C Caesar ad eam partem pervēnit quae nōndum flūmen tränsierat (B. G. I, 12), this river the Helvetians were (in the act of) crossing: ... Caesar came up to that part which had not yet crossed the river.

208. The pure perfect emphasizes the present result of a past action and is equivalent to the English present perfect in has and have.

Tandem aliquandō L. Catilinam ex urbe èiēecimus (II Cat. I, 1), at last we have driven Lucius Catiline out of the city.

209. The following verb forms are pure perfect tenses in which the present result of the action is so prominent as to make the perfects equivalent to present tenses :

cōgnōvī and nōvī, I have learned =I know

cōnsuēvī, I have become accustoned =I am accustomed

memini, $I$ have recalled $=I$ remember

odi, I have come to hate $=I$ hate

210. In the same way the pluperfect of the above verbs is used as the equivalent of the imperfect or perfect tenses. cōgnōveram, I had learned $=I$ knew

211. Pluperfect Tense. - The pluperfect is used to express an action completed in past time before some other past action.

Caesar ad eam partem pervēnit quae nōndum flūmen trānsierat (B. G. I, 12), Caesar came to that part which had not yet crossed the river. 
212. Future Tense. - The future tense is used of an action which is about to take place. To represent future time the Latin does not employ the present as the English frequently does, but the future, or even the future perfect.

Cum veniet (vēnerit), when he comes (will have come).

213. Future Perfect Tense. - The future perfect tense is used of a future action which will be completed before some other future action, and is especially common in subordinate clauses to express action prior to a future main. verb.

Quod sī fêcerit, comprehendētur, if he does this, he will be arrested. (He will not be arrested until after he has done it.)

\section{Questions}

214. Ordinary questions in Latin take the indicative mood. When a question is not introduced by an interrogative pronoun, adjective, or adverb, one of the words indicated in 215-217 may be used.

215. Nonne may introduce the question when the speaker or writer wishes to show that an affirmative answer is anticipated.

Nōnne eum interfici iubēbis, will you not order him to be put to death? (The answer yes is anticipated.)

216. Num may introduce the question when one wishes to show that a negative answer is anticipated.

Num eum interfici iubēbis, you will not order him to be put to death, will you? (The answer no is anticipated.)

217. The enclitic -ne may introduce the question when one merely asks for information without indicating what 
: nswer is anticipated. The enclitic is attached to the ' mphatic word (usually the verb), which is then placed irst.

Iubēbisne eum interfici, will you order him to be put to death?

218. Deliberative or Dubitative Questions. - Questions which indicate doubt or hesitation on the part of the ;peaker are put in the subjunctive, the present subjuncjive for present time and the imperfect for past time.

Ėloquar an sileam (Aen. III, 39), shall I speak or keep silence?

219. Rhetorical Questions. - Questions which are asked for rhetorical effect, expressing the speaker's feeling of indignation, impossibility, absurdity, or emotion, are put in the subjunctive, the present for present time and the imperfect for past time. The implied answer to such questions is a negative statement.

Hōc vêrō quis ferre possit, èbriōsōs sobriīs insidiārī (II Cat. V, 10), but who can endure this, that drunken men should plot against the sober?

Hōc tantum bellum quis umquam arbitrāêêtur ab ūnō imperātōre cōnfici posse (L. M. XI, 31), who would ever have supposed that so great a war could be completed by one general?

220. Questions asked only for rhetorical effect sometimes have the indicative.

Quid ego hōsce hominēs commemor̄̄ (IV Cat. VIII, 16), why am I mentioning these men? (Cf. IV Cat. VII, 15.)

221. Double Questions. - Double questions are introduced as follows:

(whether) $\ldots$ or $\left\{\begin{array}{l}\text { utrum } \ldots \text { an } \\ \text {-ne } \ldots \text { an } \\ -\quad \ldots \text { an } \ldots \text { an }\end{array}\right.$

222. In double direct questions or not is expressed by 
annōn. In double indirect questions, or not is expressed by necne.

Quaero utrum is clēmēns an inhūmānissimus esse videātur (IV Cat. VI, 12), I ask whether he would seem merciful or most inhuman.

Fuistī in nocturnō conventū annōn, were you present at that night meeting or not?

Quaesīì ā Catilīnā in nocturnō conventū fuisset necne (II Cat. VI, 13),

I asked Catiline whether he had been present at that night meeting or not.

223. Answers. - The Latin has no exact equivalent for the English yes or no.

224. For yes the Latin repeats the emphatic word or words of the question, or uses one of the following expressions :

vērō, truly; sānē, surely; etiam, even so ; ita (est), so it is

225. For no the Latin negatives the emphatic word or words of the question, or uses :

nōn, no; nōn ita, not so; minimēe (vērō), by no means, not at all

\section{Wishes}

226. Wishes are expressed by the subjunctive and are usually introduced by utinam, would that $O$ that! etc. The negative is ne.

227. Wishes referring to the future which are possible of fulfillment take the present subjunctive. Utinam is not always necessary.

Utinam tibi istam mentem dī duint (= dent) (I Cat. IX, 22), would that the gods would give you that intention!

228. Unfulfilled wishes referring to present time take the imperfect subjunctive and are regularly introduced by utinam. 
Ut nam virōrum fortium cōpiam tantam habērētis (L. M. X, 27), would that you had so great a number of brave nen!

229. Unfulfilled wishes referring to past time take the i uperfect subjunctive and are regularly introduced by u. inam.

Ư inam ille omnīs sēcum suās cōpiās èd $\bar{x} x i s s e t$ (II Cat. II, 4), would that he had taken out with him all his forces!

230. Velim, I would that! or mālim, I should prefer that! may replace utinam in wishes referring to the finture.

I'elim hōs sēcum èd̄icat, I wish that he would take out these men with him!

231. Vellem, I would that! or māllem, I should prefer that! may replace utinam in wishes referring to present or past time.

Vellem hōs sēcum ēduceret, I would that he were taking these men out with him!

Māllem hōs sēcum èdūxisset (II Cat. III, 5), I should prefer that he had taken out these men with him!

\section{Potential Subjunctive}

232. The potential subjunctive may be used to indicate an action as possible, the present tense representing present or future time, the imperfect representing past time. This kind of subjunctive is restricted to the usages mentioned in 233 and 234. The negative is nōn.

233. The potential subjunctive may be used in a few phrases like the following:

Quaerat quispiam, some one may ask.

Dīcat quispiam, some one may say.

234. The potential subjunctive may be used in sentences 
which may be regarded as the apodoses of ideal or unreal conditions. Cf. 303, 306-307.

Libenter haec cōram cum Q. Catulō disputārem (L. M. XXII, 66), gladly would I discuss this face to face with Quintus Catulus (if it were possible). Apodosis of a present unreal condition.

This is the commonest use of the potential subjunctive and includes :

a. The subjunctive of the indefinite second person singular, translated : you, one, any one.

Migrantēs cernās (Aen. IV, 401), you (= any one) might see them moving about.

$b$. The guarded form of statement in the subjunctives: velim, I should like; nōlim, I should not be willing; mālim, I should prefer.

235. Rhetorical questions may be classed as potential subjunctives. Cf. 219.

\section{Hortatory Subjunctive}

236. Entreaties and mild commands in the first and third persons are expressed by the present subjunctive. The negative is ne. This is sometimes called the "imperative subjunctive" and in the third person the "jussive subjunctive."

Exeant; proficiscantur (II Cat. IV, 6), let them go away; let them depart. Optēmus ... quam querāmur (II Cat. VII, 16), let us hope rather than complain.

\section{Imperative Mood}

237. Commands are expressed by the imperative mood.

238. Ordinary commands such as look to immediate fulfillment are expressed by the first (present) imperative. This is the common form. 
I $\bar{u} t \bar{a}$ iam istam mentem ; mihi crēele; obliviscere caedis et incendiōrum (I Cat. III, 6), change that intention of yours; believe me; forget about murder and burning.

239. The second (future) imperative is used in such 8 sneral and standing orders and directions as appear in li,ws, precepts, and prophecies. But the following verbs I gularly use the second (future) imperative instead of 1. 1e first (present).

st:iō, know

neminī, remember scītō, know (sing.) mementō, remember (sing.) scitōte, know (plur.) mementōte, remember (plur.)

240. Prohibitions (Negative Commands). - Prohibitions are regularly expressed by nōlī (sing.), or nōlīte (plur.), be unwilling, do not, with the present infinitive. Negative commands are not expressed by nē or nōn with the imperative in classical prose.

Quā rē nōlīte dubitāre (L. M. XXIII, 68), therefore do not hesitate.

\section{TABLE OF IMPERATIVE CONSTRUCTIONS}

\section{AFFIRMATIVE}

\section{SinguLAR}

1. laudem, let me praise

2. laudā, praise (thou)

3. laudet, let him praise
Plural

lauđēmus, let us praise

laudāte, praise (ye)

laudent, let them praise

\section{NEGATIVE - .}

1. nē laudem, let me not praise

2. nōlī laudāre, do not praise

3. nē laudet, let him not praise nē laudēmus, let us not praise nōlīte laudāre, do not praise $\mathrm{ne}$ laudent, let them not praise

\section{Sequence of Tenses}

242. In the subordinate clause of a complex sentence the tense of a subjunctive is governed by the following rule, called the "sequence of tenses": 
1. If the main verb expresses present or future time, the subordinate subjunctive is in the present or perfect. These tenses are called "primary" or "principal" tenses.

2. If the main verb expresses past time, the subordinate subjunctive is in the imperfect or pluperfect. These tenses are called "secondary" or "historical" tenses.

\section{PRIMARY (PRINCIPAL) TENSES}

\section{INDICATIVE}

Present

Future

Future Perfect
SubJunctive

Present

Perfect

\begin{tabular}{lc}
\multicolumn{1}{c}{ SECONDARY (HISTORICAL) TENSES } \\
Imperfect & Imperfect \\
Perfect & Pluperfect \\
Pluperfect &
\end{tabular}

243. How to apply the Rule of Tense Sequence. - In primary sequence the present subjunctive is used to express action going on at the same time as the action of the main verb, or to express action which will happen after the time of the main verb.

Sciō quid faciās, I know what you are doing.

244. In primary sequence the perfect subjunctive is used to express action which is completed at the time of the action of the main verb.

Sciō quid fièceris, I know what you have done (did).

245. In secondary sequence the imperfect subjunctive is used to express an action going on at the same time as the action of the main verb, or which was to happen after the time of the main verb.

Sciēbam quid facerēs, I knew what you were doing. 
246. In secondary sequence the pluperfect subjunctive is used to express an action completed at the time when tl e action of the main verb took place.

Sciēbam quid fēcissēs, I knew what you had done.

247. Exceptional Sequence. - The perfect tense is reguIirly a secondary tense and takes secondary sequence, yet sometimes primary sequence is used, especially in l'ssult clauses. Cf. 260.

Viāiōrēs nostrī tam fortiter pūgnāvērunt ut hodiē līberī sīmus, our ancestors fought so bravely that to-day we are free.

248. A perfect infinitive or a dependent perfect subjunctive requires secondary sequence even when the main rerb is primary.

Inicit illās gentēs veritās esse nē Caesar venīret, he says that those tribes feared that Caesar would come.

$\mathrm{Ab}$ eō quaeram cūr mē monuerit ut manēerem, I shall ask him why he advised me to stay.

249. A subjunctive dependent on an imperfect or pluperfect subjunctive follows secondary sequence. So especially in unreal conditions.

Sì ipsī haec neque attingere . . possēmus, tamen ea mīrārī dēbērēmus, etiam cum in aliis vidèèemus (A. VII, 17), if we were not able to attain to these ourselves, still we ought to admire them when we see them in others.

250. When a future perfect indicative or a perfect subjunctive is made a dependent subjunctive, it becomes :

1. In primary sequence a perfect subjunctive.

2. In secondary sequence a pluperfect subjunctive.

Lentulus, cum sē praetūrā abdicāverit, in cūstōdiam trādātur, let Lentulus be consigned to prison when he has resigned his praetorship. Cènsēbunt ut Lentulus, cum sē praetūrā abdicāererit, in cūstōdiam trādātur.

Cênsuērunt ut Lentulus, cum sē praetūra abdicāsset, in cūstōdiam trāderetur (III Cat. VI, 14). 


\section{Indirect Questions}

251. Indirect questions include all subordinate clauses introduced by an interrogative word. The mood is subjunctive and the tense is governed by the rule for sequence of tenses.

Quis sim sciēs; . . cōgitā quem in locum sīs prōgressus (III Cat.

$\mathrm{V}, 12)$, who I am you will know; . . . consider how far you have gone.

For the particles used in double questions, see 221-222.

252. When a subordinate clause in the subjunctive is to express time clearly future with reference to the main verb, the active periphrastic is used. This is particularly common in indirect questions.

Dicam quid factūrus sit, I shall tell what he is going to do, is about to do, intends to do.

Dixi quid factūrus esset, I told what he was going to do, was about to do, intended to do.

\section{Purpose (Final) Clauses}

253. Purpose (final) clauses are clauses which express the purpose of the action of the main verb. The mood is subjunctive and the tense present or imperfect, according to the rule for the sequence of tenses.

254. Pure purpose clauses are introduced by ut, that, or nē, that . . not.

Lēgātōs mittunt ut pācem petant, they send ambassadors to beg peace. Hôc fêcit $n \bar{e}$ urbs dêlêrêtur, he did this that the city might not be destroyed.

255. Relative clauses of purpose are introduced by a relative pronoun, adjective, or adverb. 
J ēgātōs mittunt qū̄ (=utīi) pācem petant, they send anbassadors to (who may, that they may) beg peace.

] 'eliquī neque quō sē reciperent neque quem ad modum sē deffenderent habēbant (B. G. IV, 26), the rest had neither any place to retreat to, nor any way to defend themselves.

256. Quō is regularly used to introduce a purpose clause which contains a comparative.

Yñlitēs manipulōs laxāre iussit $q u \bar{o}$ facilius glađiīs ūtī possent (B. G. II, 25), he ordered the soldiers to open out the ranks so that they might be able to use their swords more easily.

\section{VARIOUS WAYS OF EXPRESSING PURPOSE}

(1) Lēgātōs mīsit ut pācem peterent (254)

(2) Lēgātōs mìsit quī pācem peterent (255)

(3) Lēgātōs pācis petenđae causā mīsit (381)

(4) Lēgātōs ad pācem petenđam mīsit (381)

(5) Lēgātōs pācem petītum mīsit (390)

(6) Explōrātōrēs speculanđī causā mīsit (381)

(7) Explōrātōrēs ad speculanđum mīsit (381)

(8) Equitātum suīs auxiliō mīsit (90-91)

$\left\{\begin{array}{l}\text { he sent ambassadors to } \\ \text { seek peace. }\end{array}\right.$
$\left\{\begin{array}{l}\text { he sent scouts to spy. } \\ \text { aid his men (B. G. } \\ \text { IV, 37). }\end{array}\right.$

N.B. Purpose must not be expressed by the infinitive in Latin.

\section{Result (Consecutive Clauses)}

258. Result (consecutive) clauses are subordinate clauses which express the result of the action of the main verb. The subjunctive mood is used.

259. Result clauses are introduced by ut, that, ut . . nōn, that . . not, or a relative. Frequently some correlative is found in the main clause, such as tam, sicc, ita, tantus, tot, etc.

Tanta erat hörum celeritäs ut equōrum cursum adaequārent (B. G. I, 48), so great was their swiftness that they equaled the speed of the horses. 
Quoniam sunt ita multī $u t$ carcer eōs capere $n \bar{o} n$ possit (II Cat. X, $22)$, since they are so many that the prison cannot hold them.

Quae insula tam parva fuit quae (=ut ea) nōn portūs suōs dēfenderet (L. M. XVIII, 54), what island was so small that it did not defend its own harbors?

a. Without governing a gerund in English may sometimes be translated by ut ... nōn and a result clause in Latin.

Nōn possunt multī fortūnās āmittere $u t \boldsymbol{n o ̄ n}$ plūrēs sēcum in eanđem trahant calamitātem (L. M. VII, 19), many men cannot lose their fortunes without involving ( = so that they do not involve) many others with them in the same misfortune.

260. In result clauses the following exception to the rule for sequence of tenses is to be noted. The perfect subjunctive (more rarely the present) may be used after a main verb in a secondary tense to emphasize the present result of a past action. Cf. 247.

\section{Substantive Clauses}

261. A substantive clause is a clause which is used as a substantive; that is, as the subject or object of some verb, or in apposition with a noun or pronoun.

262. Substantive Purpose Clauses. - Substantive clauses introduced by ut or nē are used after many verbs and expressions of command, entreaty, request, and exhortation. Some of the commonest verbs taking this construction are:

rogō, ask

petō, ask, beg

postulō, demand

pōscō, demand

ōrō, beg

optō, wish, beg

concēdō, permit imperō, command, order

mandō, instruct, command

praecipiō, instruct

cēnseō, decree

dēcernō, decree

persuāđeō, persuacie ${ }^{1}$

hortor, urge cūrō, take care

videō, see to it 1

prōvideō, see to it ${ }^{1}$ negōtium dō, employ permittō, allow moneō, advise ${ }^{1}$ admoneō, advise, varn ${ }^{1}$

1 With a different meaning many of these verbs take indirect discourse. 
( ivitātī persuāsit $u t$ dē fïnibus exīrent (B. G. I, 2), he persuaded (the citizens of) the state to emigrate from their country. I ostulāvit $n \bar{e}$ aut Aeduīs aut eōrum sociīs bellum inferret (B. G. I, 43), he demanded that he should not make war on the Aedui or their allies.

263. Iubeō, order ; vetō, forbid ; sinō, permit; cupiō, deire, are exceptions and take the infinitive only. Cf. 331-332.

264. Substantive Result Clauses. - Substantive clauses introduced by ut or ut . . . nōn are used after many verbs and expressions to denote the accomplishment of some result. Some of the commonest of the verbs are:

$\left.\begin{array}{l}\text { faciō, } \\ \text { efficiō, } \\ \text { perficiō, }\end{array}\right\}$ bring it about, make

fit, it happens, the result is

accidit, it happens

contingit, it happens

attingit, it happens

èvenit, the outcome is

additur, added to this is the fact accēdit, there is the additional fact, added to this is the fact

sequitur, it follows

cōnsequitur, it follows

restat, it remains

reliquum est, it remains

mōs est, it is the custom

iūs est, it is right, it is the law

Fēcērunt $u t$ cōnsimilis fugae profectiō vidēerètur (B. G. II, 11), they made their departure seem like flight.

Accēdēbat ut . . nihil saxa timèrent (B. G. III, 13), added to this was the fact that they feared the rocks not at all.

265. Negative result clauses and negative purpose clauses differ greatly in the use of introductory particles. Study the following table:

Negative Purpose

that... not

that ... no one

that . . . nothing

that ... no (Adj.)

that... never nē

nể quis

nē quid

nē quī (qua, quod)

nē umquam
Negative Result

ut . . . nōn

ut . . . nēmō

ut . . . nihil

ut . . nūllus, $-a$, -um

ut ... numquam 
Dēcrēvit senātus ut cōnsul vidēret $n \bar{e}$ quid rēs pūblica dētrīmentī caperet (I Cat. II, 4), the senate decreed that the consul should see to it that the state suffered no harm. (Purpose.)

Cōnsul effēcit ut nihil rēs pūblica dētrīmentī caperet, the consul brought it to pass that the state suffered no harm. (Result.)

266. Substantive Clauses with Verbs of Fearing. - Substantive clauses used with verbs and other expressions of fearing take the subjunctive introduced by nē, that, or ut, that ... not.

Quod verērentur $n \bar{e}$ ad eōs exercitus noster addūcerètur (B. G. II, 1), because they feared that our army would be led against them. Quī verērī videntur ut habeam satis praesidī (IV Cat. VII, 14), who seem to fear that I shall not have sufficient forces.

267. Nē . . . nōn replaces ut when :

a. The verb of fearing is negatived.

$b$. The negative goes with some particular word.

Nōn verentur $\boldsymbol{n} \overline{\boldsymbol{e}}$ id facere $\boldsymbol{n} \overline{\boldsymbol{o}} \boldsymbol{n}$ possit, they do not fear that he will be unable to do this.

268. Verbs of fearing when meaning afraid to take the infinitive. Cf. 329.

Verētur Rōmae manēre, he is afraid to stay in Rome.

269. Clauses Dependent on Verbs of Hindering, etc. Verbs and expressions of hindering, preventing, and refusing govern subordinate clauses in the subjunctive. The subordinate clauses are introduced:

a. By nē or quōminus when the main verb is in the affirmative.

b. By quin or quōminus when the main verb is negative. Hōs multitūdinem dēterrēre ne erūmentum cōnferant (B. G. I, 17), (that) these men prevent the people from getting the grain together. Germānī retinērī nōon poterant quīn tẹla in nostrōs conicerent (B. G. I, 47), the Germans could not be restrained from hurling javelins at our men. 
( Nāvēs) quae ventō tenēbantur quōminus in eundem portum venīre possent (B. G. IV, 22), which were prevented by the wind from being able to reach the same harbor.

خ Teque recūsātūrōs quōminus sub illōrum imperiō essent (B. G. I, $31)$, nor would they refuse to be under their power.

270. Some of the commonest verbs thus used are :

\begin{tabular}{|c|c|c|}
\hline $\begin{array}{l}\text { impediō, } \\
\text { dēterreō, } \\
\text { obstō, }\end{array}$ & hinder, prevent, deter & $\begin{array}{l}\text { tenē̄, keep (from) } \\
\text { retineō, restrain } \\
\text { recūsō, refuse }\end{array}$ \\
\hline
\end{tabular}

271. But prohibeō regularly takes the present infinitive. 'Quī Teutonōs intrā fīnēs ingredī prohibuerint (B. G. II, 4), who prevented the Teutons from entering their country.

272. Clauses Dependent on Verbs of Doubting. - Negative verbs and expressions of doubting are followed by the subjunctive introduced by quin.

Nōn dubium erat quīn Helvētiī plūrimum possent (B. G. I, 3), there was no doubt that the Helvetians were the most powerful.

273. When dubitō means hesitate, it is followed by the infinitive.

Dubitās, Catilīna, abīre (I Cat. VIII, 20), do you hesitate, Catiline, to go away?

\section{Characteristic Clauses (Clauses of Tendency)}

274. Relative clauses which express some characteristic of the antecedent of the relative are called "characteristic clauses" and have their verbs in the subjunctive. Characteristic clauses tell not what thing, but what kind of thing, is meant.

Tempestās coörta est quae nostrās nāvēs frangeret, a storm came up which (such as) wrecked our ships.

275. Characteristic clauses are especially common after the following expressions : 
1. Dignus est qui ..., he is worthy to ...; indignus est qui ...., he is unworthy to ...; idōneus est quĩ...., he is suitable to ...

2. Ünus est quĩ . . ., he is the only one who ...; sōlus est quī ...., he is the only one who...

3. Phrases where the relative's antecedent is indefinite : e.g.,

Sunt quī ..., there are some who...

Est quī..., there is some one who...

Quis est quī..., who is there who...

Nēmō est quī ..., there is no one who...

Nihil est quod..., there is nothing which...

4. Ëius modi quī ..., of such a sort as to ...; is est qui . . . , he is such a man as to ...

Nōn erit idōneus quī ad bellum Asiāticum mittātur (L. M. XXIII, 66), he will not be a suitable man to be sent to the war in Asia.

$\bar{U} n u s$ erat $q u \bar{\imath}$ addūcī nōn posset (B. G. I, 31), he was the only one who could not be persuaded.

Sunt quī diccant (II Cat. VI, 12), there are some who say.

Quid est quod in hāc urbe tē dēlectāre possit (I Cat. VI, 13), what is there which can please you in this city?

Illae đissēnsiōnēs erant êeius modĩ quae ad commutandem rem pūblicam pertinēent (III Cat. X, 25), those disturbances were of such a character as to aim at a revolution.

276. Frequently relative clauses of characteristic are hardly to be distinguished from relative result clauses. Compare the last example above with the following:

Illae dissēnsiōnēs èius mod̄̄ fuērunt $u t$ interneciōne cīvium $d \bar{i} i \bar{u} d i$ cātae sint (III Cat. X, 25), those disturbances were of such a character that they were settled by a slaughter of citizens.

\section{Temporal Clauses}

277. Cum temporal clauses referring to present or future time are regularly in the indicative. 
( uibus gaudiīs exsultābis cum nōn audiēs ... (I Cat. X, 26), in what joy you will exult when you will not hear...

278. The imperfect and pluperfect subjunctive are 1. sed with cum temporal to describe the situation or cir( umstances of an action.

('um ā mē quoque id respōnsum tulissēe (I Cat. VIII, 19), when you had received this answer from me also. (Uum haesitāret, quaesīì (II Cat. VI, 13), when he hesitated, I asked.

279. But cum temporal is used with past tenses of the ndicative, especially the perfect, to define or date the iime when an action occurred.

Cēpit māgnum virtūtis frūctum cum omnēs dīxistis (L. M. XX, 59), he received a great tribute to his ability, when you all said...

280. If the cum clause is preceded in the main clause by tum, eō tempore, or some other expression of definite time, the time of the action is thereby definitely indicated and the cum clause takes the indicative, according to 279 . Nam tum cum in Asiā rēs māgnās permultī ämīserant (L. M. VII, 19), for at the time when very many men had lost great fortunes in Asia.

Note. Do not confuse this use of tum ... . cum with cum ... tum, not only... but also.

Dīviciācus quī cum māgnae partis hārum regiōnum tum etiam Brittaniae imperium obtinuit (B. G. II, 4), Diviciacus who had pover not only over a large part of these regions but also over Britain.

281. When the cum clause contains the main idea or principal event of the sentence, while the main clause merely describes the attendant circumstance, the verb of the cum clause is in the indicative. This is called "cum inversum."

Vix ea fātus eram, gemitū cum tālia reddit (Aen. II, 323), scarce had I said this when, with a groan he spoke as follows. 
282. When the cum clause is used to express past action repeated or recurring, the indicative is used.

Neque, cum aliquid mandārat, cōnfectum putābat (III Cat. VII, 16), nor when he had given an order did he consider it carried out.

283. Clauses introduced by postquam (post . . . quam), after; ut, when; ubi, when; simulatque (simulac), as soon as, etc.

In narrative writing, clauses introduced by these conjunctions commonly take the perfect indicative. Such clauses are usually translated in English by the pluperfect.

Postquam L. Lucullus vēnit (L. M. IX, 23), after L. Lucullus had come.

Simulatque iussus est, pāruit (II Cat. VI, 12), as soon as he was ordered, he obeyed.

Ut prīmum ex puerīs excessit Archiās (A. III, 4), as soon as Archias had grown up from boyhood.

284. With the future or future perfect cum replaces postquam, after.

Cum eum vīder⿳亠口冋, Rōmam ređībō, after I see him, I shall return to Rome.

285. Dum, quoad, quamdiū, meaning while, as long as, introduce temporal clauses which express action extending over a period of time. If the main clause represents action extending over the whole period of time represented by the dum clause, the dum clause takes any tense of the indicative which the sense demands. This use of a dum clause is called "complete coextension."

Dum canēbat, audientēs loquēbantur, while (= all the while that) he was singing, the audience was talking.

Quam diū erit quisquam quī tē dēfendere audeat, vìvēs (I Cat. II, 6), as long as there will be any one who dares defend you, you will live.

Quoad potuit restitit (B. G. IV, 12), he held out as long as he could. 
286. Dum, while (=within the period that), represents $\mathrm{n}$ action extending over a period of time. If the main - erb represents action occurring at some point of time vithin that period or breaking into it, the dum clause lakes the present indicative. This use of a dum-clause is (alled "partial coextension."

Jum canit quidam exiit, while he was singing a certain man went out. Jum haec geruntur, Sabinus pervēnit (B. G. III, 17), while these things were going on Sabinus arrived.

287. Even in indirect discourse the dum clause of partial coextension resists attraction and remains in the present indicative.

288. Dum, dōnec, quoad, until, take the indicative of a fact of actual occurrence, but the subjunctive when an action is anticipated, desired, or intended.

Fūi in litterīs scrībendīs occupātus, itaque intrā moenia mānsī dum dìlücesscēbat, I was busy. writing letters and so I stayed in the city until it was growing light. (The staying in the city was accidental because he was preoccupied in writing.)

Timuit latrōnēs, itaque intrā moenia morātus est $\mathbf{d u m}$ dīlūcēsceret, he was afraid of robbers and so waited inside the city until it should grow light. (He wanted to avoid the robbers.)

Dum reliquae nāvēs eō convenīrent, ad hōram nōnam exspectāvit (B. G. IV. 23), he waited up to the ninth hour until the rest of the ships should assemble there. (His intention in waiting was to meet the other ships.)

289. Priusquam (prius ... quam), and antequam (ante . . quam), before, take the indicative of a fact of actual occurrence, but the subjunctive of an act anticipated, forestalled, or intended. With the indicative the tenses commonly employed are the perfect or future perfect, sometimes the present. 
Foedus ictum est, priusquam proelium commisērunt, a treaty was made before they began battle. (The battle actually took place.)

Foedus ictum est, priusquam proelium committerent, a treaty was made before the battle should be begun. (The purpose in making the treaty was to prevent a battle.)

Caesar priusquam sē hostēs ex terrōre reciperent in fīnīs Suessiōnum exercitum dūxit (B. G. II, 12), Caesar led his army into the territory of the Suessiones before the enemy should recover from fear. (Caesar did not wish the enemy to get any chance to recover.)

Note. Priusquam is more common than antequam.

\section{Clauses of Proviso}

290. Dum, dummodo, modo, provided that, take the subjunctive. The negative is ne.

Māgnō mē metū līberābis, dum modo inter mē atque tē mūrus intersit

(I Cat. V, 10), you will free me from great fear provided that there is a wall between you and me.

\section{Causal Clauses}

291. Causal clauses are introduced by cum, quod, quia, quoniam, quandō, or a relative.

292. Causal clauses introduced by cum always take the subjunctive.

Quae cum ita sint (I Cat. V, 10), since this is the case.

293. Causal clauses introduced by a relative take the subjunctive.

$\overline{0}$ fortūnāte adulēscēns $q u \bar{\imath}$ tuae virtūtis Homērum praecōnem invēneris (A. X, 24), O fortunate youth who have (to have, since you have), had a Homer to herald your glory. (quī= cum tū.)

294. Causal clauses introduced by quod, quia, quoniam, or quando take the indicative when they give a reason which the speaker or writer accepts as a fact and will vouch for. 
E elvētiī quoque reliquōs Gallōs virtūte praecēdunt, quod ferē cotīđiānīs proeliis contendunt (B. G. I, 1), the Helvetians also surpass the rest of the Gauls in bravery because they fight in almost daily battles. (The reason is bere stated as a well-known and accepted fact; hence the indicative mood.)

295. Causal clauses introduced by quod, quia, quoniam, (¿uandō, take the subjunctive when the reason is one which , he writer or speaker quotes on the authority of another, jut which he himself may not be able to vouch for.

Yihi grātiae aguntur (ā senātū), quod prōvidentiā meā rēs pūblica sit līberāta (III Cat. VI, 14), I was thanked (by the senate) because by my foresight the state was freed. (The quod clause gives the senate's reason for the vote of thanks.)

296. Causal clauses dependent on verbs of emotion, such as queror, complain; laetor, rejoice ; doleō, grieve, etc., are regularly introduced by quod, and frequently take the subjunctive to indicate the grounds of the emotion.

Haeduī vēnērunt questum quod Harūdēs fīnīs eōrum populārentur (B. G. I, 37), the Haedui came to complain because the Harudes were ravaging their territory.

297. Quoniam usually introduces a self-evident or wellknown fact, and hence commonly takes the indicative.

Quoniam iam nox est (III Cat. XII, 29), since it is now night.

\section{Conditional Sentences}

298. Conditional sentences are complex sentences. The subordinate clause is called the protasis and contains the condition; the main clause is called the apodosis and contains the conclusion.

299. Words used to introduce the Conditional Clause:

1. Si, if', is the common introductory word.

Sī ille adest, manēbō, if he is here, I will stay. 
2. Nisi, unless, if . . not, commonly introduces a negative protasis.

Nisi ille vēnerit, nōn manēbō, if he doesn't come, I will not stay.

Sì . . nōn is used in place of nisi to introduce a negative protasis.

a. When some particular word is negatived.

$\boldsymbol{S} \overline{\boldsymbol{z}}$ id facere $\boldsymbol{n} \overline{\boldsymbol{o}} \boldsymbol{n}$ potest, if he is unable to do this.

$b$. When the negative protasis has been preceded by an affirmative protasis with the same idea involved.

Sì vēnerit manēbō; sī nōn vēnerit discēdam, if he comes, I will stay; if he does not come, I will leave.

3. Sin, but if, is used for an adversative protasis.

Sīn autem servīre meae laudì māvis (I Cat. IX, 23), but if you prefer to add to my praise.

300. Types of Conditional Sentences. - Conditional sentences are of three types: (1) logical conditions; (2) ideal conditions; (3) unreal conditions. ${ }^{1}$

301. Type I. - Logical conditions are conditions so stated as to imply nothing as to the truth of the condition. The indicative is used in both clauses in any tense which the sense demands. They may refer to present, past, or future time.

Present : Caesar si pūgnat, vincit, if Caesar is fighting, he is conquering.

PAsT: Caesar, sī pūgnāvit, vīcit, if Caesar fought, he conquered. Future: Caesar, sī pūgnābit, vincet, if Caesar fights, he will conquer.

Caesar, si pūgnāverit, vincet, if Caesar fights, he will conquer.

${ }^{1}$ Logical $=$ simple $=$ real. $\quad$ Ideal $=$ future less vivid. $\quad$ Unreal $=$ con trary to fact. 
302. Note that the Latin employs the future or even $i$ le future perfect in the protasis of a future condition where t te English usually uses the present tense. Cf. 212-213.

303. Type II. - Ideal conditions refer to future time. ?he supposed case is assumed as possible of fulfillment. 'he present subjunctive is employed in both clauses. sometimes the perfect subjunctive is used to represent the cction as completed, especially in the protasis.

Caesar, sī pügnet, vincat, if Caesar should fight, he would conquer.

304. Note the auxiliaries used in English in the future logical and future ideal conditions.

\begin{tabular}{lll}
\multicolumn{2}{c}{ Future logical } & Future Ideal \\
Protasis: & shall, will & should, were to \\
Apodosis : & shall, will & would, should
\end{tabular}

Future Logical: Sī hōc faciet, eum laudãbimus, if he does (will do) this, we shall praise him.

Future Ideal: Sì hōc faciat, eum laudèmus, if he should do this, (were to do this), we should praise him.

305. Type III. - Unreal conditions are conditions in which the supposed case is so stated as to imply by the form of the condition that the case is unreal or impossible of fulfillment. The subjunctive is used in both clauses, and the time may be present or past.

306. Present Time. - Unreal conditions have the imperfect subjunctive in both clauses to express unreality or non-fulfillment in present time.

Caesar, sī pügnāret, vinceret, if Caesar were fighting, he would be conquering.

Sì tē parentēs timèrent, aliquō concēederēe (I Cat. VII, 17), if your parents feared you, you would go off somewhere.

307. Past Time. - Unreal conditions use the pluperfect 
subjunctive in both clauses to express unreality or nonfulfillment in past time.

Caesar, si pügnāvisset, viccisset, if Caesar had fought, he would have conquered.

Sī hōc idem Mārcō Mārcellō dīxissem, iam mihi cōnsulī senātus vim et manūs intulisset (I Cat. VIII, 21), if I had said the same thing to Marcus Marcellus, the senate would have laid violent hands on me though I am the consul.

308. Mixed Conditions. - Sometimes the protasis of an unreal condition is in past time (pluperfect subjunctive), while the apodosis is in present time (imperfect subjunctive) or vice versa.

Tum sī plūs apud populum Rōmānum auctōritās tua quam populī Rōmānī vēra causa valuisset, hodiē hōc orbis terrae imperium tenērēemus? (L. M. XVII, 53), if your influence had then had more weight than the true interests of the Roman people, should we to-day be holding supremacy over all the world?

309. Verbs of possibility and power, obligation and necessity, and verbs in the active or passive periphrastic conjugation usually employ the imperfect or perfect indicative instead of the imperfect or pluperfect subjunctive - in the apodoses of unreal conditions.

Quod sī Rōmae Pompēius prīvātus esset hōc tempore, tamen ad tartum bellum erat mittendus (L.' M. XVII, 50), but if Pompey were a private citizen at Rome at the present time, still he ought to be sent to so great a war.

Itaque, crề̄ō, sī cīvis Rōmānus Archiās lēgibus nōn esset, ut cīvitāte dōnārētur perficere nōn potuit (A. X, 25), and so, I suppose, if Archias were not legally a Roman citizen, he couldn't manage to be presented with citizenship.

310. This use of the indicative in unreal conditions occurs most frequently with the following verbs:

possum, be able licet, may oportet, ought dēbeō, ought necesse est, must, and with the periphrastic conjugations. 
311. In logical conditions or (sometimes) in ideal con(1) tions the apodosis may assume any form which the s nse demands, especially an imperative or hortatory subji nctive.

S: mihi cōnflāre vīs invidiam, rēctā perge in exsilium (I Cat. IX, 23), if you want to stir up hatred against me, go straight into exile.

312. The protasis of a conditional sentence is fre( uently expressed by a participle, an ablative absolute, or $\therefore 1$ adjective.

Q aid tandem (tabernīs) incēnsīs futūrum fuit? (IV Cat. VII, 17), what, pray, would have happened if their shops had been burned?

313. Conditional clauses of comparison are introduced by velutsī, tamquam sĩ, acsī, quāsī, ut sī, as if. The verb is in the subjunctive, the tense being determined by the rule for sequence of tenses, though the English translation would seem to place them among unreal conditions.

Absentis Ariovistī crūđēlitātem, velutsī cōram adesset, horruērunt (B. G. I, 32), they shuddered at the cruetty of Ariovistus in his absence just as if he were present in person.

Ab urbe fugit veluts $\bar{\imath}$ in exsilium ire iussus sit, he is fleeing from the city as if he had been ordered to go into exile.

\section{Concessive Clauses}

314. Concessive clauses are commonly introduced by cum; quī; quamquam; etsī, etiamsī, tametsī; quamvīs; licet; ut; nè.

315. Cum, although, introducing concessive clauses, takes the subjunctive.

Cum ad vesperum pāgnātum sit āversum hostem vidère nēmō potuit (B. G. I, 26), though the battle lasted until evening, no one could see an enemy in fight. 
316. $\mathrm{Qu} \overline{\mathrm{i}}=\mathrm{cum}$ is, etc., introducing concessive clauses, takes the subjunctive.

Praesertim qū̄ nōs nōn pūgnandō sed tacendō superāre potuerint (III Cat. IX, 22), especially since they could have conquered us not by fighting but by keeping silent.

317. Quamquam, although, introducing concessive clauses, takes the indicative.

Nam P. Lentulus, quamquam iūs praetōis $\bar{a} m \imath \bar{s} e r a t$, tamen sē magistrātū abdicāvit (III Cat. VI, 15), for Publius Lentulus, although he had lost the rights of a praetor, resigned his office.

318. Quamquam is frequently used to introduce the main clause, in such cases being equivalent to the English, and yet ...

Quamquam mihi nihil ab istīs iam nocērī potest (III Cat. XII, 27), and yet no harm can be done to me now by those (scoundrels).

319. Quamvis, however much you please, although, introduces concessive clauses in the subjunctive.

Quamvīs increpitent socii (Aen. III, 454), however much your followers find fault with you.

320. Licet, although, takes the subjunctive. In this use licet retains its verbal nature, and therefore, since licet is a primary tense, the verb dependent on it must be present or perfect.

Licet ille sit fortis, tamen sē dēdet, brave though he be, still he will surrender.

321. Ut, granted that, and nē, granted that . . . not, introduce a statement conceded or granted for the sake of argument. The verb is in the subjunctive, and the main clause often contains some correlative to the ut or nē, such as tamen. 
Tt omnia contrā opīniōnem acciderent, tamen sē plūrimum nāvibus posse (B. G. III, 9), though everything turned out contrary to their expectation, still they were best provided with ships.

322. Etsī, etiamsī, tametsī, even if, although, introduce ioncessive clauses. The mood is determined by the priniples which govern the mood of conditional clauses.

Ets $\bar{\imath}$ dux ipse mihi imperet, nōn pāream, even if the conmander himself should command me, I would not obey.

\section{Infinitives}

323. The Infinitive as Subject. - The infinitive is a verbal noun and as such may be the subject of a verb. When so used its gender is neuter, and any predicate adjective which modifies it will be neuter.

Hūius ōrātiōnis difficilius est exitium quam prīncipium invenīre (L. M. I, 3), it is harder to find a conclusion to this speech than a beginning.

324. The subjective infinitive may itself take an accusative subject.

Cōnstituērunt optimum esse domum suam quemque revertī (B. G. II, 10), they decided that it was best for each one to return to his own home.

325. Note the construction with the following impersonal verbs :

1. Placet, it pleases, and videtur, it seems best, take the dative of the person and an infinitive subject.

$\boldsymbol{L} \overline{\boldsymbol{e}} \boldsymbol{g} \overline{\boldsymbol{a}} \boldsymbol{t} \overline{\boldsymbol{o}}$ placuit mīlitēs castrīs continēere, it pleased the lieutenant (the lieutenant thought it best) to keep the soldiers in camp. Visum est Caesari in Galliam contendere, it seemed best to Caesar to hasten into Gaul.

2. Oportet, it is fitting, it is proper, ought, takes (a) the 
accusative and the infinitive, or (b) the subjunctive without ut.

$\left.\begin{array}{l}\text { Eum interficī oportet, } \\ \text { Interficiātur oportet, }\end{array}\right\}$ he ought to be put to death.

3. Licet, it is permitted, may; necesse est, it is necessary, must, take (a) the accusative and infinitive, (b) the dative and infinitive, (c) the subjunctive without ut.

Nōn licet mē manēre, Nōn licet mihi manēre, I am not allowed to stay, I may not stay. Nōn licet maneam, Necesse est $m \bar{e}$ discēdere, $\left.\begin{array}{l}\text { Necesse est mihi discēdere, } \\ \text { Necesse est } \text { discēdam, }\end{array}\right\}$ must depart.

326. For the expression of past time with such verbs as licet, oportet, etc., the Latin employs a present infinitive and a past tense of the auxiliary verb where the English employs a perfect infinitive with a present or past auxiliary.
Mè venire oportuit, I ought to have come.
Venìre dēbuī, I ought to have come.
Venire potui, $I$ could have come.
Mihi venire licuit, I might have come.

327. A predicate noun or adjective in the above constructions (325) is put in the same case as the noun which it defines.

Nōn licuit Gracchum iterum esse tribūnum, Gracchus was not permitted Nōn licuit Gracchō iterum esse tribūnō, $\}$ to be tribune again.

328. Complementary Infinitives. - Infinitives without subjects expressed may depend on and complete the meaning of certain other verbs. Infinitives thus used are called "complementary infinitives." 
329. The following verbs may take complementary nfinitives :

\begin{tabular}{|c|c|c|c|}
\hline \multirow{2}{*}{\multicolumn{2}{|c|}{$\begin{array}{l}\text { rolō, wish, be willing } \\
\text { 1ōlō, be unwilling } \\
\text { nā̄o, prefer } \\
\text { upiō, desire } \\
\text { studeō, desire }\end{array}$}} & $\begin{array}{l}\text { nesciō, } n \\
\text { dubitō, } h \\
\text { moror, } d\end{array}$ & \multirow{2}{*}{$\begin{array}{l}\text { cōnsuēscō, become ac- } \\
\quad \text { customed } \\
\text { audeō, dare } \\
\text { dēbeō, ought } \\
\text { statuōo, } \\
\text { cōnstituō, }\} \begin{array}{l}\text { decide, de- } \\
\text { termine }\end{array}\end{array}$} \\
\hline & & & \\
\hline $\left.\begin{array}{l}\text { aetuō, } \\
\text { ereor, } \\
\text { imeō, }\end{array}\right\}$ & $\begin{array}{l}\text { be afraid }(t o) \text {. } \\
\text { Cf. } 268\end{array}$ & $\begin{array}{l}\text { mātūrō, hasten } \\
\text { coepīi, began } \\
\text { incipiō, begin } \\
\text { cōnor, try, attempt } \\
\text { temptōo, try, attempt } \\
\text { possum, be able, can } \\
\text { soleō, be accustomed }\end{array}$ & $\begin{array}{l}\text { cōnstituō, \} termine } \\
\text { parō, prepare } \\
\text { dēsistō, cease } \\
\text { dicor, be said } \\
\text { videor, seém }\end{array}$ \\
\hline
\end{tabular}

Quō facilius, sī trānssìre cōnārentur, prohibēere posset (B. G. I, 8), that he might the more easily be able to prevent them if they should attempt to cross.

330. Predicate nouns or adjectives following complementary infinitives agree with the subject of the main verb.

Neque potest imperātor sevērus esse (L. M. XIII, 38), nor can a general be severe.

331. Objective Infinitive. - An infinitive may be used as the object of another verb. So with many of the above verbs (329), when the subject of the infinitive is not the same as the subject of the verb on which it depends, and therefore must be expressed.

332. The following verbs very frequently take an objective infinitive :

volō, nōlō, mālō, cupīō, prohibeō, iubeō, vetō, sinō, cōgō, patior Orgetorīgem ex vinculīs causam dīcere coēgērunt (B. G. I, 4), they forced Orgetorix to plead his cause in chains.

Ille vōs omnēs salvōs esse voluit (III Cat. IX, 22), he wished all of you to be safe. 
333. Infinitive in Indirect Discourse. - Statements dependent on some verb of saying, thinking, knowing, perceiving, etc., take the infinitive with subject accusative.

Direct Statement: Belgae sunt fortēs, the Belgians are brave. Indirect Statement : Caesar dīcit Belgās esse fortīs, Caesar says that the Belgians are brave. Here the sunt in direct statement has become esse in the indirect, and its subject Belgae has become Belgās.

334. Verbs of hoping and promising in English frequently have the construction of complementary infinitive. In Latin they regularly take a future infinitive with the subject accusative expressed. Such verbs are : spērō, hope; prōmittō and polliceor, promise.

Quĩ sêsē mē in meō lectulō interfectūrōos esse pollicērentur (I Cat. IV, 9), who promised to kill me in my bed (promised that they would kill me).

335. Negō, deny, say . . not, is regularly used in Latin instead of dīcō ... nōn, etc.

(Caesar) negat sē posse iter üllī per prōvinciam dare (B. G. I, 8), (Caesar) said that he could not grant a passage through the province to any one.

336. Verbs of emotion sometimes take the construction of indirect discourse. Such verbs are: gaudeō and laetor, rejoice; doleō and lūgeō, mourn, grieve; mïror, wonder; queror, complain.

Urbem è suīs faucibus èreptam esse lūget (II Cat. I, 2), he grieves that the city has been snatched from his jaws.

337. Tenses of the Infinitive in Indirect Discourse. - The infinitive has three tenses, - present, perfect, and future. Deponent verbs have future active infinitives. 
338. The present infinitive in indirect discourse repre,ents action going on at the time of the verb of saying, and llways stands for a present tense of the direct statement.

Jirect Statement : Caesar vincit, Caesar is conquering. indiRECT Discourse : Dícit Caesarem vincere, he says that Caesar is conquering.

Dixit Caesarem vincere, he said that Caesar was conquering.

339. The perfect infinitive in indirect discourse represents action completed before the time of the action of the verb of saying, and may stand for an imperfect, perfect, or pluperfect of the direct statement.

Direct Statement : Caesar vincēbat (vīcit, vīcerat), Caesar was conquering, conquered, had conquered.

Indirect Discounse : Dīcit Caesarem vicisse, he says that Caesar was conquering (conquered, had conquered).

Dixit Caesarem vicisse, he said that Caesar conquered (had conquered).

340. The future infinitive in indirect discourse represents action as future with reference to the time of the main verb of saying, and stands for a future tense of the direct statement.

Direct Statement : Caesar vincet, Caesar will conquer.

Indrect Discourse : Dicit Caesarem victūrum esse, he says that Caesar will conquer.

Dixit Caesarem victūrum esse, he said that Caesar would conquer.

341. When a future passive infinitive is required in indirect discourse, the expressions fore ut, futūrum esse ut, with the subjunctive (whose tense depends on the verb of saying), are generally used instead of the forms of the future passive found in the grammars, - amātum irī, etc. 
(Dīviciācus dixit) quā ex rē futūrum esse utī tōtīus Galliae animī à sē äverterentur (B. G. I, 20), Diviciacus said that, as a result of this, the allegiance of all Gaul would be turned from him. Fut $\bar{u}$ -

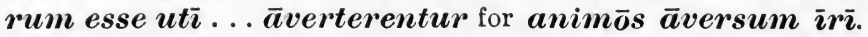

342. So also a verb which has no future participle can have no future active infinitive and must employ the same circumlocution, futūrum esse ut.

Māgnam in spem veniēbat fore ut pertināciā dēsisteret (B. G. I, 42), he was beginning to have great hopes that he would desist from his obstinacy. Here fore ut . . . dēsisteret replaces the missing future infinitive of dēsistō.

343. Since possum has no future infinitive, its present infinitive is used instead.

Tōtīus Galliae sēsē potīī posse spērant (B. G. I, 3), they hope that they will be able to gain possession of all Gaul.

344. Personal and Impersonal Constructions with Verbs of Saying, etc. - Passive verbs of saying, etc., in the simple tenses (present, imperfect, future), are followed by a complementary infinitive instead of the infinitive with subject accusative. This. is called the "personal construction." Mulierēs ex urbe profectae esse dicuntur, the women are said to have set forth from the city.

Not:

Dicitur mulierēs ex urbe profectās esse, it is said that the women set forth from the city.

345. Passive verbs of saying, etc., in the compound tenses (perfect, pluperfect, future perfect), are used impersonally with the infinitive and subject accusative. This is called the "impersonal construction."

Dictum est Méedèam ex Pontō profūgisse, it is said tr. Medea fled from Pontus. 


\section{Indirect Discourse}

346. When a sentence of the direct discourse is changed nto indirect discourse, the following changes take place.

347. The main verb becomes an infinitive with subject accusative, and all subordinate clauses become subjunctive.

348. The tense of the infinitive is determined by the rules given in 337-343. The tense of the subjunctive is determined by the rule of sequence 242-250.

Eōs quĩ restitissent infīirmōs sine illō fore putābam (III Cat. II, 3), I thought that those who had remained behind would be weak without him.

349. When a command (237-239) or an entreaty (236) is put into indirect discourse, it is put in the subjunctive, the tense being determined by the verb of saying according to the rule for the sequence of tenses.

Sì quid vultis, ad İdūs Aprīlis revertiminī, if you want anything, return on the Ides of April.

Caesar respondit sī quid vellent, ad İdūs Aprïlis reverterentur (B. G. I, 7), Caesar answered that if they wanted anything, they should return on the Ides of April. Note that vultis becomes subjunctive because it is a subordinate clause in indirect discourse, and revertimini (imperative) becomes reverterentur according to 349 .

350. Subordinate clauses which are purely parenthetioal or explanatory on the part of the writer or speaker are not properly a part of the indirect discourse and therefore remain indicative if they would be so in direct discourse.

Equitēs Rōōmānī dētulērunt Bïthȳniae, quae nunc vestra prōvincia est, vĩcōs exūstōs esse complūrēs (L. M. II, 5), Roman knights have report th that many villages of Bithynia, which is now our province, have $t, n$ burned. Cicero is quoting a message from the Roman knighr ss qut the clause quae . . . est is his own statement and not a part is the message. 


\section{Conditional Sentences in Indirect Discourse. - A} conditional sentence is a complex sentence; hence when changed into indirect discourse its main verb (of the apodosis) becomes infinitive and its subordinate verb (of the protasis) becomes subjunctive.

352. Logical Conditions in Indirect Discourse - These conditions follow the rules laid down in 347-348. For examples, see 355 .

353. Ideal Conditions in Indirect Discourse. - Ideal cónditions represent future time, and therefore when an ideal condition is transformed into indirect discourse, the apodosis becomes a future infinitive and the protasis becomes subjunctive, the tense being determined by the rule for the sequence of tenses. Cf. 355 .

Notz. Future logical and ideal conditions have the same form in indirect discourse. Cf. 355.

354. Unreal Conditions in Indirect Discourse. - When unreal conditions are transformed into indirect discourse, they follow the rules of 347 . The following peculiarities are to be noted, however:

1. The tense of the protasis remains unchanged, being unaffected by the rule for the sequence of tenses.

- 2. An active apodosis becomes the perfect infinitive of the active periphrastic conjugation, -ürus fuisse.

3. When the verb of the apodosis is passive or has no future participle, the circumlocution, futūrum fuisse ut (with the imperfectsubjunctive), is used. Cf. 355.

Note. The apodoses of present and past unreal conditions have the same form in indirect discuurse. 
358. Apodoses of present unreal conditions and all pi ssive apodoses of unreal conditions are unchanged when di pendent on such constructions as are mentioned in 357 .

\section{Participles}

359. Participles are verb forms used as adjectives.

360. Transitive verbs have three participles as follows:

Present

ACTIVE: laudāns, praising

l'ISSIVE :
Perfect

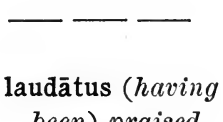

FUTURE laudātūrus, about to praise been) praised

361. Deponent verbs have all three participles. cōnāns, trying cōnātus, having tried cōnātūrus, about to try

362. Tenses. - The tense of the participles represents time only with reference to the verb of the clause in which they stand.

363. The present participle represents action taking place at the same time as the action of the clause in which it stands.

Mithridātēs fugiēns maximam vim aurī in Pontō relīquit (L. M. IX, 22), Mithridates while fleeing ( = in his flight) left a great amount of gold in Pontus.

364. The perfect passive participle represents action completed before the action of the verb of its clause.

Id calamitāte doctī memoriā tenēre đēbēmus (L. M. VII, 19), we (who have been) taught by disaster ought to remember this.

365. The future participle represents action which is or was to take place after the action of the verb of its clause.

Moritūrì tê salütāmus, we (who are) about to die salute you. 
366. Participles as Adjectives. - Participles may be used purely as adjectives.

audācia effrēnāta, unbridled boldness poena dēbita, deserved punishment

367. Participles as Nouns. - The following participles are frequently used as nouns:

sapiēns, philosopher amāns, a lover victī, the conquered audientês, the audience doctī, the wise, wise men, learned men Itaque mortem sapientēs numquam invītī oppetīērunt (IV Cat. IV,

7), and so philosopher's have never met death reluctantly.

368. Frequently a perfect passive participle modifying a noun is itself equivalent to an English abstract noun. $\mathrm{Ab}$ urbe conditā, from the founding of the city (from the city founded). Ante Christum nātum, before the birth of Christ (before Christ born). Post cīvitātem datam, after the bestowal of citizenship (after citizenship bestowed).

369. Ablative Absolute. - A noun and a participle (present or perfect) may be used together in the ablative case to form an ablative absolute, the combination being equivalent to a clause. Cf. 371.

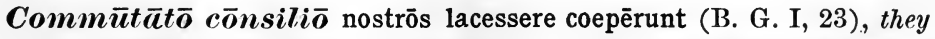
changed their plan and began to harass our men (their plan having been changed, they began, etc.).

370. The Latin has no present participle for the verb sum; hence two nouns or a noun and an adjective may form an ablative absolute where the present participle of sum (English being) is understood.

Messālā et Pīsōne cōnsulibus (B. G. I, 2), in the consulship of Messala and Piso (Messala and Piso being consuls).

Quā Sêquanīs invītìs ire nōn poterant (B. G. I, 9), and by this (road) they could not go if the Sequani were unwilling (the Sequani being unwilling). 
371. An ablative absolute may be equivalent to various $k$ nds of clauses, the translation to be adopted in any $\because$ ven case depending on the context. Thus the sentence, c ppid̄o incēnsō hostēs discēdent, may be variously transanslated as follows :

I he enemy will withdraw when the town has been burned. (Time.) The enemy will withdraw if the town is burned. (Condition.) The enemy will withdraw because the town has been hurned. (Cause.) i'he enemy will withdraw though the town has been burned. (Concession.) ithe enemy will burn the town and withdraw. (Coördinate clause.)

372. The ablative absolute construction with a perfect passive participle is in most cases a substitute for a lacking perfect active participle with a direct object. Thus, in the sentence,

The enemy having seized the heights began battle,

having seized is a perfect active participle and has no Latin equivalent. Before being translated into Latin, therefore, the English must be changed into the passive form.

The enemy, the heights having been seized, began battle, hostēs, superiōribus locīs occupātīs, proelium commisērunt.

373. Deponent verbs, however, take the active construction and follow the English exactly. Note the use of participles in the following:

Itaque apud oppidum morātī agrōsque dêpopulātī vīcisque incēnsīs ad castra Caesaris contendērunt (B. G. II, 7), accordingly having tarried near the town, having laid waste the fields, and having burned the villages, they hastened to Caesar's camp.

374. When not to use the Ablative Absolute. - A noun or pronoun may not be used in the ablative absolute construction except when it refers to a person or thing different from any noun or pronoun of the clause in which it 
stands. Therefore when the noun or pronoun to be modified by the participle can have any grammatical relation, as subject, object, etc., with any other part of the sentence, no ablative absolute is possible.

Hostēs suās cōpiās ex castrīs êd luctās instrūxērunt (B. G. II, 8), the enemy having led forth their troops from the camp drew them up. Here the ablative absolute is impossible.

375. Participles as Clauses. - A participle is frequently used in Latin where the English employs a clause.

1. Participle for a relative clause.

Quod Aeduōs frātrēs saepe numerō ā senātū appellātōs in servitūte vidēbat tenērī (B. G. I, 33), Because he saw that the Aedui, who had often been called brothers by the senate, were held in slavery.

2. Participle for a causal clause.

Trānsīsse Rhēnum sēsē nōn suā sponte sed rogātum ā Gallīs (B. G. I, 44), (he said) that he had crossed the Rhine not of his own accord, but because he had been asked oy the Gauls.

3. Participle for a temporal clause.

Cónantēes dicere prohibuit (B. G. I, 47), when they tried to speak, he prevented them.

4. Participle for a concessive clause.

Ut ille paulsus superātus que rēgnāret (L. M. III, 8), so that, although he had been defeated and conquered, he continued to reign.

5. Participle for a conditional clause.

Damnātum poenam sequī oportēbat (B. G. I, 4), if condemned, punishment must overtake him.

6. Participle equivalent to a verb correlative with the main verb.

Reliquōs omnēs $c_{\bar{o}}$ nsecūtē equitēs nostrī interfēcērunt (B. G. I, 53), our cavalry overtook all the rest and killed them. 


\section{Gerund and Gerundive}

376. The gerund is a verbal noun which is used in t) e genitive, dative, accusative, and ablative singular o1.ly. The accusative gerund is used only with the peposition ad. The infinitive takes the place of the 1) () minative of the gerund and the gerund as direct object. The dative of the gerund is rare.

N )M. Laudāre est facile, praising is easy. Cf. $376,323$.

(ren. Studium bellandi, a desire of making war.

J) AT. Locus pūgnandō iđōneus, a spot suitable for fighting. Cf. 376 .

¿ cc. Parātus ad pügnandum, prepared for fighting.

A BL. Nōn pūgnandō sed tacenđō, not by fighting, but by keeping silent.

377. Gerundive. - The gerundive is a verbal adjective used in all genders, numbers, and cases. The dative case is not often used, being replaced by ad with the accusative. Nov. Vir laudandus, a man to be praised.

Gev. Studium urbis capiendae, a desire of captur ing the city.

DAT. Locus castrīs pōnendīs idōneus, a spot suitable for pitching camp.

Acc. Parātus ad urbem capiendam, prepared for capturing the city.

AвL. Discimus bonis librīs legendis, we learn by reading good books.

378. Gerund vs. Gerundive. - The English possesses no gerundive, but the gerund construction in English may stand for a gerund or a gerundive construction in Latin. If the English gerund takes an object, the gerundive construction is commonly employed in Latin. If the English gerund has no object, the gerund is employed in Latin. Thus:

A plan of withdrawing, cōnsilium discēdendī. In this . phrase the English gerund has no object. Hence the gerund is employed in Latin.

379. A plan of destroying the state, cōnsilium dēlendae 
reì pūblicae. In this phrase the English gerund has an object, and therefore in Latin the gerundive construction is used. Since the gerundive is merely an adjective, the Latin makes the reī pūblicae genitive depending on cōnsilium, though the English puts the gerund in the genitive. The gerundive, dēlendae, of course, modifies reî pūblicae.

380. The reflexive pronoun suī may be singular or plural. When it is used with the gerundive, it is treated as singular even though its meaning is plural.

Multī civitātis prīncipēs sū̄ conservandī causā profūgērunt (I Cat. III, 7), many of the leading men of the state fled to save themselves.

381. The accusative of the gerund or gerundive with ad, for, or the genitive followed by causā, for the purpose $o f$, may be used to express purpose.

Urbis capiendae causā, for the purpose of capturing the city, to capture the city.

Pūgnandī causā, for the purpose of fighting, to fight.

Ad urbem capiendam, for capturing the city, to capture the city.

Ad pügnandum, for fighting, to fight.

382. The gerundive modifying the object may be used to express purpose or in place of an object clause. Some of the commonest verbs so used are :

$\begin{array}{ll}\text { cūrō, provide for, attend to } & \text { attribūō, assign } \\ \text { concē̄ō, intrust, hand over } & \text { d̄o, give } \\ \text { relinquō, leave } & \text { trādō, give over }\end{array}$

Pontem faciendum cūrat (B. G. I, 13), he provides for the construction of a bridge $=$ he has a bridge built.

Attribuit nōs trucīdandōs Cethēgō, et cēterōs cīvìs interficiendōs Gabiniō, urbem inflammandam Cassiō, tōtam İtaliam vāstandam diripiendamque Catilīnae (IV Cat. VI, 13), he assigned the murder of us to Cethegus and the slaughter of the rest of the citizens to Gabinius, the burning of the city to Cassius, and the devastation and plundering of all Italy to Catiline. 


\section{Passive Periphrastic Conjugation}

383. The passive (second) periphrastic conjugation is a co nbination of the gerundive and the various forms of the ve b sum. There is alway's some idea of necessity or o) igation involved, which may be translated in various wiys.

Catilina interficiendus est, $\left\{\begin{array}{l}\text { Catiline must be killed. } \\ \text { Catiline ought to be killed. } \\ \text { Catiline is to be killed. }\end{array}\right.$

384. With the passive periphrastic the agent or doer, the person on whom the necessity rests, is expressed by the dative.

Catilīna $\boldsymbol{n \overline { o }} \overline{\boldsymbol{u}} \boldsymbol{s}$ interficiendus est, $\left\{\begin{array}{l}\text { Catiline must be killed by us. } \\ \text { We must kill Catiline. } \\ \text { We ought to kill Catiline. }\end{array}\right.$

385. When the passive periphrastic is to be used, all active sentences in English must be changed into the passive.

We must kill Catiline =Catiline must be killed by us, Catilina nōbis interficiendus est.

386. When an intransitive verb is to be used in the passive periphrastic, it must be put in the impersonal form.

We must set out $=$ it must be set out by us, nōbīs proficīscendum est.

387. The verbs mentioned in 79-80 are used impersonally in the passive (cf. 82), and therefore must be so used in the passive periphrastic.

They must be persuaded = it must be persuaded to them, persuādendum est illis. 
388. If this construction would bring two datives together in such a way as to cause ambiguity, instead of the dative of agent, the ablative of agent is employed.

We must persuade them, illīs $\overline{\boldsymbol{a}} \boldsymbol{n o} \bar{b} \boldsymbol{b} s$ persuādendum est.

389. For the passive periphrastic forms in unreal conditions, cf. 309-310.

\section{Supine}

390. Supine in -um. - The accusative supine in -um may be used with verbs of motion to express purpose. Cf. 257. It may take an object.

Lègātōs ad Caesarem mittunt rogātum auxilium (B. G. I, 11), they send ambassadors to Caesar to ask for aid.

391. Supine in $-\overline{\boldsymbol{u}}$. - The ablative supine in $-\overline{\mathbf{u}}$ is used with certain adjectives as an ablative of specification. The following supines are most common:

$$
\text { dictū, to say factū, to do visū, to see, to behold }
$$

392. The supine in $-\overline{\mathrm{u}}$ is most frequently used with the following adjectives :
facilis, easy
horribilis, horrible
optimus, best
difficilis, difficult
mīrābilis, wonderful
incrēdibilis, incredible
Optimum factū, the best thing to do.
Facile factū, easy to do.
Mīrābile dictū, wonderful to say.

393. The supine in $-\overline{\mathrm{u}}$ never takes an object.

\section{CONJUNCTIONS}

394. Copulative conjunctions are those which merely connect affirmatively or negatively two words, phrases, or clauses.

et, and, is the simplest connective and is colorless.

-que, and (enclitic), connects words, etc., which are closely related to each other. Pater māterque. 
atque (ac), and, and also, and especially, emphasizes the second word connected.

)is immortālibus atque Iovī Stātōrī (I Cat. V, 11), to the immortal gods and especially to Jupiter Stator.

quoque, also, too, emphasizes the word to which it belongs.

Tũ quoque, you also.

neque (nec), nor, and . . . not, is regularly used in place of et . . . nōn. Nec tamen ego sum ille ferreus (IV Cat. II, 3), and yet I am not such a hard-hearted man. . .

395. When three or more words are to be connected by and, (1) omit all conjunctions; (2) connect all with et; or (3) unite the last two by -que (not et).

$\left.\begin{array}{l}\text { Hominēs, mulierēs, puerī, } \\ (\boldsymbol{E} t) \text { hominēs et mulierēs et puerī, } \\ \text { Hominēs mulierēs pueríque, }\end{array}\right\}$ the men, women, and children.

396. When a noun is modified by two adjectives, the adjectives should be connected by a conjunction.

Multī et summī virī, many very great men.

397. Adversative conjunctions are those which denote opposition.

sed, $b u t$, the common word.

autem, but, on the other hand, however, is the weakest adversative and frequently $=$ moreover, furthermore. It is always postpositive. vērum, but, is like sed, but is not so common. It is usually first. vē̄ō, truly, indeed, always postpositive.

at, $b u t$, introduces an objection or contrast and is very strong. tamen, nevertheless, however, still, yet, is really concessive.

398. Disjunctive conjunctions indicate an alternative. aut, or, permits no choice and excludes one of the alternatives.

Ut aut oderint aut ament (L. M. XV, 43), so that they either hate or love.

vel, or, permits a choice of the alternatives. It frequently introduces a correction. So also with -ve, which is less common.

sive, or, allows a choice and is used much as vel.

an, or, is used particularly in questions. Cf. 221. 
399. Correlative conjunctions are those conjunctions which occur in pairs.

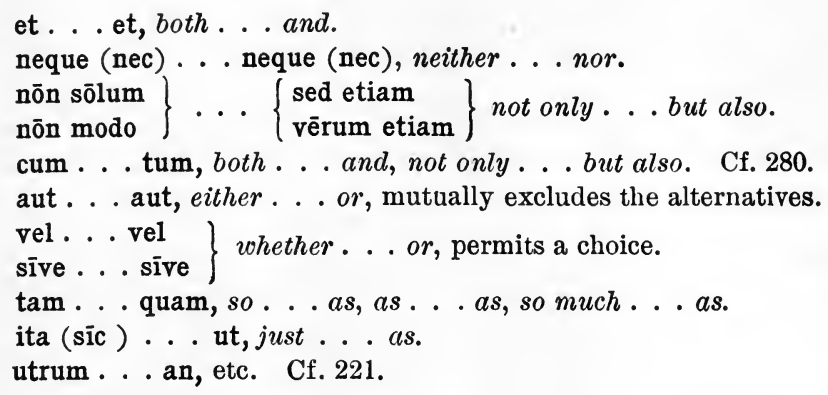

\section{ORDER OF WORDS}

400. In a Latin sentence the subject normally stands first and the verb last, with the direct and indirect objects between. The modifiers of the nouns follow the rules given below. Cf. 402-410. The modifiers of the verb precede the verb.

Hīc imperātor equitibus Gallōrum lēgātum cuī cōnfĩdēbat statim praefēcit, this general immediately placed a lieutenant whom he trusted in charge of the cavalry of the Gauls.

401. But the order of words usually varies from this regularity to emphasize some word or phrase, or to connect the sentence more closely with what precedes or follows. Cf. 41.

Tibi hunc librum dō, I give you this book, it is to you that I give this book.

Ego tibi hunc librum dō, it is I who am giving you this book.

Hunc librum tibi dō, this is the book which I give you.

$\boldsymbol{D} \bar{o}$ tibi hunc librum, I give you this book.

\section{Modifiers of the Noun}

402. If an adjective is emphatic, it usually precedes its noun. Otherwise the noun commonly precedes, 
403. Demonstrative, relative, and interrogative adjecives regularly precede their nouns.

404. Possessive adjectives usually follow their nouns unless emphatic.

405. Adjectives of quantity, as well as the commoner adjectives like bonus, etc., usually precede their nouns.

406. Cardinal numerals regularly precede their nouns, while ordinals regularly follow.

Duae cohortēs legiōnis septimae.

407. Many adjectives have a fixed position.

Populus Rōmānus, the Roman people. Rēs pūblica, the state.

Lingua Lātīna, the Latin language. Rēs frūmentāria, the grain supply. Dì immortālēs, the immortal gods. Novae rês, a revolution.

Patrēs cōnscriptī, the senators.

Cōnsul dēsignnātus, the consul elect.

408. Appositives regularly follow the nouns with which they are in apposition.

409. Dependent genitives, except when relative or interrogative, commonly follow their nouns unless emphatic. Some genitive phrases have a fixed order.

Senātūs cōnsultum, a decree of the senate.

410. When a noun is limited by an adjective and a dependent genitive, a common order is, - adjective, genitive, noun.

Multae Galliae gentēs, many races of Gaul.

411. Adverbs and adverbial phrases regularly precede the word modified. But ferē, paene, prope, usually follow.

412. Postpositives. - 1. Autem, enim, quidem, quoque, 
vērō, can never come first in the clause. So commonly with igitur.

2. Nè . . quidem incloses the emphasized word. Nē Rōmānì quidem, not even the Romans.

3. Inquam, $I$ say, etc., always comes after one or more words of a direct quotation.

413. Enclitics. - The enclitics -que, -ne, -ve, are appended to the first word connected; or, when connecting clauses, to the first word of the connected clause.

414. Prepositions. - Prepositions regularly precede their nouns, but a monosyllabic preposition is often placed between the adjective and its noun. So regularly when the adjective is a relative or interrogative, and in the ablative of manner when cum is used.

Quā dē causā, for which reason, for this reason, therefore. Māgnā cum virtūte, with great courage.

\section{Order of Words in Simple Sentences and Clauses}

415. Interrogatives and relatives regularly placed first in the clause.

416. Words or phrases which serve to connect a clause or sentence with what precedes regularly come first.

Haec cum animadvertisset (B. G. I, 40), when he had noticed this.

417. In questions, when -ne is appended to the verb, the verb is placed first.

418. The verb sum may be placed wherever convenient, much as in English. But when meaning exist, it regularly comes first. 
419. A complementary infinitive regularly precedes the verb on which it depends, but a negative may intervene. Dīcere nōn possum, I cannot tell.

\section{Order of Words in Compound and Complex Sentences}

420. When the same verb would be required in both clauses of a compound or complex sentence, it is commonly expressed but once, unless ambiguity would result. Quārum ūnam incolunt Belgae, aliam Aquītān̄i, tertiam quī ipsōrum linguã Celtae, nostrā Gallī appellantur (B. G. I, 1), of these (parts) the Belgians inhabit one, the Aquitanians (inhabit) another, (and) the third (those inhabit) who in their own language are called Celts (and) in our (language are called) Gauls.

421. When the subject or object (direct or indirect) of the subordinate verb refers to the same person or thing as that of the main verb, it regularly stands first, followed by the subordinate clause.

Caesar, cum vēnisset, haec dixit, when Caesar came, he spoke thus.

422. Temporal, conditional, and concessive clauses commonly precede the main clause.

423. Indirect questions, purpose clauses, and result clauses, commonly follow the main verb.

424. When there are several subordinate clauses, they should be so arranged as to avoid a succession of verbs.

425. A succession of clauses connected by et, etc., is to be avoided, and when possible a compound clause should be made a complex sentence by subordinating one or more of the correlative clauses.

Caesar removed the horses of all, addressed his men, and began battle, Caesar omnium remōtîs equīs cohortātus suōs proelium commissit. (B. G. I, 25.) 


\section{EXPLANATIONS AND SUGGESTIONS}

The references given at the beginning of each lesson are to the sections of the Elements of Syntax, which forms the first part of this book. On pages 184, 277, 390 will be found a corresponding set of references to the grammars of Harkness, Allen and Greenough, Bennett, Gildersleeve and Lodge. These references may be used separately, or in connection with the references to the Elements of Syntax.

A special vocabulary for each lesson will be found on pages 169,263 , 371. These vocabularies should be carefully learned.

Words which are inclosed in parentheses in the exercises should be omitted in translation.

In preparing a lesson, the references and special vocabulary should be thoroughly mastered before any attempt is made to write the exercise. 


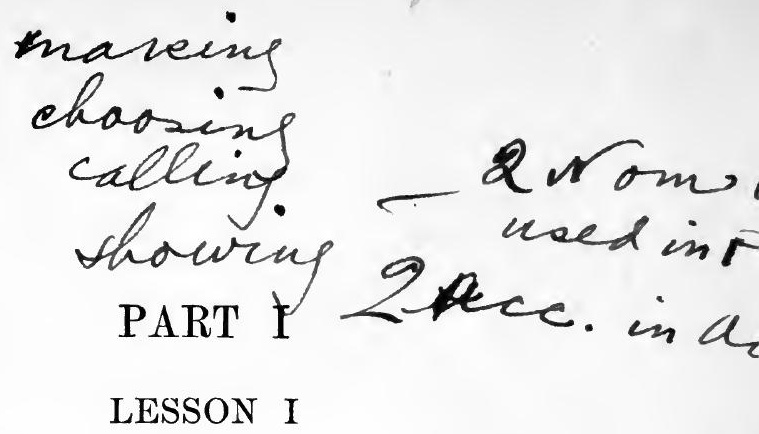

\section{TENSES OF THE INDICATIVE}

426. References :

1. Present Tense : 201.

2. Imperfect Tense : 203.

3. Future Tense : 212.
4. Perfect Tense : 206-208.

5. Pluperfect Tense : 211.

6. Future Perfect Tense : 213.

\section{EXERCISE FOR WRITTEN TRANSLATION}

1. We have conquered the Gauls and are leading our troops into Italy.

2. Many states had been conquered, and we were waging war with the Germans.

3. One part we did not conquer, for a deep river separated that part from us.

4. A deep river separates the Helvetians from the province.

5. Merchants used to bring many things from the province into Gaul.

6. Rivers and high mountains separate the fields of the Helvetians from Gaul.

7. If we conquer ${ }^{1}$ the Gauls, we shall have their broad fields.

8. Rivers and mountains shut in the narrow territories of the Helvetians. 
9. Many states of Gaul formed conspiracies against the Roman people.

10. One part of the Helvetians was easily conquered.

11. We used to inhabit this part of Gaul, but now live in Belgium.

12. If we form ${ }^{1}$ a conspiracy, the Roman forces will be led into our territory.

13. All things have been prepared; now we are awaiting our leader.

14. War had been waged with many states, and now our troops were being led into the province.

15. But they did not remain in the province, for conspiracies were being formed in Gaul.

16. Rivers and mountains separate the territories of the Aeduans from other states.

17. The states of Gaul used to form conspiracies.

18. The greatest states often do not have the bravest forces.

19. If the Helvetians come ${ }^{1}$ into these territories, they will have broad fields.

20. The bravest Gauls inhabited Belgium.

21. The Helvetians often fought with the Germans and Aeduans.

22. Caesar conquered Gaul and waged war with the Germans.

23. This state used to wage war with the greatest states of Gaul.

24. If war is waged, ${ }^{1}$ the Germans will be conquered. 


\section{EXERCISE FOR ORAL TRANSLATION}

1. I am waging war in Gaul.

2. War is being waged in this state.

3. Merchants import these things.

4. These things are imported.

5. You (plur.) inhabit the province.

6. You (sing.) are doing this.

7. A broad river separates these fields.

8. A conspiracy is being formed.

Give these sentences with the verb in each tense of the indicative in the person, number and voice indicated.

$\left.\begin{array}{l}\text { 9. I was forming a conspiracy. } \\ \text { 10. I have broad fields. }\end{array}\right\} \begin{aligned} & \text { Give these sentences, } \\ & \text { conjugating the verb in } \\ & \text { the tense indicated. }\end{aligned}$

\section{LESSON II}

APPOSITION - PREDICATE NOUNS AND ADJECTIVESVERBS OF NAMING, CHOOSING, ETC.

429. REFERENCES:

1. Apposition : 4-5.

2. Predicate Nomịnative : 7.
3. Two Accusatives with Verbs of Naming, etc.: $67-68$.

4. Two Nominatives with Verbs of Naming, etc. : 58, 69 .

430. Explanations :

1. A predicate adjective follows the same rule as any other adjective, and agrees with its noun, the subject, in gender, number, and case.

Orgetorix nōbilissimus fuit et dītissimus, Orgetorix was the noblest and richest.

2. When a verb of naming, choosing, etc., has two accusatives, one of these is really in apposition with the other. Hence, when 'such a verb is used in the passive, 
one of these accusatives becomes the subject nominative, the other a predicate nominative.

They elected Caesar consul, Caesarem cōnsulem creāvērunt.

Caesar was elected consul, Caesar cōnsul creātus est.

3. Remember that esse cannot take an object because it is intransitive. So with all passive verbs except deponents.

\section{EXERCISE FOR WRITTEN TRANSLATION}

1. The Helvetians were neighbors of the Aeduans.

2. We consider the Belgians the bravest of the Gauls.

3. The Belgians were considered the bravest of the Gauls.

4. Orgetorix was thought (to be) the noblest in this state.

5. Therefore they chose him (as) ambassador to the neighboring states.

6. This man is.called a friend of the state, but he will seize the royal power.

7. He has become the most powerful man in Gaul.

8. Our army seems the most powerful because our soldiers are brave.

9. The soldiers will inform the general concerning this thing.

10. He has been chosen the leader of these troops, but he is not brave.

11. Dumnorix, the brother of Diviciacus, was a chief of the Aeduans.

12. Casticus was a chief of the Sequanians, neighbors of the Helvetians.

13. The Sequanians, our neighbors, have been informed concerning this conspiracy. 
14. The one route, through the province, seemed very e: sy.

15. Caesar will be informed concerning the march of i ie Helvetians.

16. The magistrates have chosen these men (as) soldiers.

17. These men we shall choose (as) magistrates.

18. They have called us (their) allies. We have been alled (their) allies.

19. Caesar is thought the most powerful general in Italy.

20. Caesar has become the most powerful general hecause his soldiers are brave.

21. Diviciacus will remain our friend because we call him our friend.

22. He is called a general because the senate has chosen him (as) general.

23. The father of Casticus, the Sequanian, was king in his state.

24. Orgetorix, the leader, chose this people (as) allies.

432. EXERCISE FOR ORAL TRANSLATION

1. Dumnorix, the brother of Diviciacus.

2. The Helvetians, a people of Gaul.

3. Our neighbors, the Belgians.

Decline in

4. I am being chosen consul.

Conjugate in the present.

5. I called him my friend. Conjugate in the perfect.

6. I shall be called your friend. Conjugate in the future.

7. I am informing the soldiers.

8. The soldiers are being informed.

9. He seems to be a powerful chief.

Give a syn10. We choose this man (as) our leader. opsis in the indicative. 


\section{LESSON III}

\section{THE ABLATIVE CASE - MEANS OR INSTRUMENT -} AGENT - SPECIFICATION - ACCOMPANIMENT

\section{REFERENCES:}
1. Means or Instrument: 127.
3. Specification : 142-143.
2. Agent : $128-129$.
4. Accompaniment : 133-134.

\section{EXERCISE FOR WRITTEN TRANSLATION}

1. The Helvetians will set out with all their forces.

2. The same plan was adopted by the neighbors of the Helvetians.

3. These men often contend with the Germans in 1 battle.

4. The royal power was seized by Orgetorix and other chiefs.

5. The Belgians surpass the Celts in courage and prestige.

6. All the states of Gaul differ from the Romans in language and laws.

7. The Helvetians were influenced by the speech of their chief, Orgetorix.

8. A leader of the Aeduans, Dumnorix by name, seized the royal power of his state.

9. We shall go forth with our friends into the territory of the Sequani.

10. The Celts fought with their enemies with swords and javelins.

11. A conspiracy has been formed by these men and war will be waged. 
12. This town was assailed by the Helvetians with ll their forces.

13. Caesar will hasten to that town with his army.

14. The Helvetians will be conquered by Caesar and lis army.

15. A conspiracy is being formed by the Gauls and we shall wage war with them.

16. These things have often been imported into Gaul by the merchants.

17. The enemy excelled us in number of men, but they were excelled by us in courage.

18. In breadth of territory we excel the Romans, but in prestige we are excelled by them.

19. Orgetorix was chosen chief by the Helvetians, and he influenced them by his speeches.

20. The royal power was being seized by a chief of the Aeduans, Dumnorix by name.

21. They had hastened with their troops into Gaul and were waging war with the Belgians.

22. With our arms we overcame the enemy, and with all their men they fled.

23. War will be waged by all these states, for a conspiracy is being formed by the chiefs.

24. With a multitude of men they have set out, and the town will be attacked by them.

\section{EXERCISE FOR ORAL TRANSLATION}

1. With Caesar; with the chief; with me; with you (sing.); with him (reflex.); with him (not reflex.); with us; peace (be) with you (plur.); with them (reflex.); with them (not reflex.). 
2. They excel us in prestige; in valor; in number of men.

3. We have been conquered by the Gauls; by the Helvetians; by arms.

4. We set out with all his troops. He fought with the enemy. He fought with a sword.

5. You (plur.) differ from us in language and laws.

6. 'This man, Diviciacus by name, has been called friend by the Romans.

7. The Romans were influenced by Caesar; by Caesar's speech.

8. Caesar is being chosen leader. Give all the tenses of the indicative.

9. We have informed Caesar. Caesar has been informed.

10. Diviciacus, the chief. Decline in all cases.

\section{LESSON IV}

\section{INDIRECT OBJECT-PLACE TO WHICH-PLACE FROM WHICH - PLACE WHERE - RELATIVE}

436. References:

1. Indirect Object : 78 .

4. Place Where: 186.

2. Place to Which : 187, 190, 191. 5. Relative Pronoun: 12, 39, 40.

3. Place from Which : $188,192$.

437. Explanations :

1. Do not confuse the indirect object with place to which. The English has the same expression for both, but whenever the English "to" is used with a verb of motion, the accusative with a preposition must be used in Latin.

He gives a book to the boy, librum puer $\bar{o}$ dat.

(Indirect Object.) He sends a book to the boy, librum ad puerum mittit. (Place to Which.) 
2. Such sentences as "I am given a book" and "I am sent a book" must be changed to the equivalent form indicated in the following examples:

$I$ an given a book $=a$ book is given to me, mihi liber datur. I am sent a book $=a$ book is sent to me, ad mé liber mittitur.

3. Sometimes in English the preposition "to" is omitted.

He gave me a book = he gave a book to me, mihi librum dedit.

He sent me a book = he sent a book to me, ad mê librum misit.

4. Be careful to use the accusative when "in" is employed with a verb of motion.

\section{EXERCISE FOR WRITTEN TRANSLATION}

1. I have given him a letter which he will send to the consul.

2. The army which is now in Gaul will be led back into Italy.

3. I have already told this to the general by whom the troops will be led to the mountains.

4. We who have formed this conspiracy will hasten out of our territory.

5. From the river by which the Sequani are separated from the Aedui we were led to that town.

6. The arms with which we fought were sent to us by the centurion.

7. We were driven down from the mountains to the city in which the general had encamped.

8. The Helvetians whose chief had formed a conspiracy were going out of their territory. -

9. The men with whom we were fighting had come out of the forest. 
10. The soldiers to whom I gave the shields will carry them to the tribune.

11. The enemy were hurling javelins down from the wall upon our (soldiers).

12. You (plur.) who have been sent into the province will assemble at ${ }^{1}$ the bank of the Rhone.

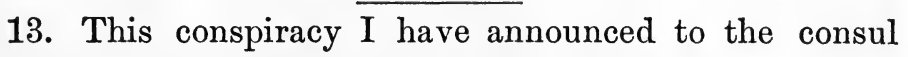
who will immediately lead his army to that place.

14. The city to which the soldiers were sent is in the province.

15. He has given the general the letter which was sent to him by the consul.

16. This was done by you who went forth from that city.

17. The mountains which separate the Helvetians from their neighbors are very high.

18. I killed him with the sword which you had given me.

19. Caesar led his army down from the hill to the bank of the river.

20. Orgetorix, by whose speech the Helvetians had been influenced, had formed a conspiracy.

21. With that legion which he had with him he hastened from the province into the territory of the Celts.

22. The man to whom I had reported this conspiracy sent a messenger to the magistrates.

23. Our (men) hastened down from the mountains into the city which the enemy had attacked.

24. We who have been appointed your chiefs will lead you into the territory of the enemy. 


\section{EXERCISE FOR ORAL TRANSLATION}

1. In Gaul. Into Gaul. Out of Gaul. Away from Gaul.

2. He gave me a horse. He sent me a horse.

3. A sword was given to me. I was given a sword.

4. You were sent a message. A message was sent you.

5. You who say this. Give in all persons in the present.

6. I who have been called a friend of the Roman people. Give in all persons of the perfect.

7. I gave the soldier a sword. I gave a sword to the soldier.

8. With the general. With swords. With us.

9. By a speech. By the general. By the soldiers.

10. Caesar, the Roman general. Decline in all cases.

\section{LESSON V}

\section{EXPRESSIONS OF PLACE-LOCATIVE CASE}

440. References :

1. Place Where : $186,189,191$.

2. Locative Case : $193,194, a, 195$,

3. Place to Which : 187, 194, $b, 195$, examples, 198.

4. Place from Which : 188, 194, c, 195, 198.

\section{EXERCISE FOR WRITTEN TRANSLATION}

1. In our camp is that embassy which has come from Geneva.

2. He set out from home and hastened by forced marches to Vesontio.

3. In these places the Helvetians often fought in battle with the Germans. 
4. In this territory our soldiers will try the fortune of war.

5. We have conquered our enemies on land and sea, and our forces are now being led home.

6. My father was in Vesontio, but I was at home.

7. They have hastened from-the-vicinity-of Geneva, and have fought in battle with us near Vesontio.

8. The army remained in camp in Gaul, but the general returned to Italy.

9. In many parts of their territories the Helvetians have burned almost all their villages.

10. In the whole camp there remained not ten soldiers.

11. He will lead forth the troops which have been stationed in winter quarters.

12. From the city of Rome the Romans often used to go to Cumae.

13. In these villages are many things which merchants have brought from the city of Tarentum.

14. He has gone from the country to the city of Rome.

15. In all Asia, Pompey was thought to be the greatest general.

16. The enemy will attack the town in which we have stationed all our forces.

17. He is now in the city of Syracuse, ${ }^{1}$ but he will return to the country.

18. All our enemies have been conquered on land and sea. Therefore our troops will remain at home.

19. It is a long journey from-the-vicinity-of Rome tothe-vicinity-of Geneva. 
20. The forces which are now in Germany will be led into the province.

21. At this place the river Rhone was not very deep.

22. At Rome and in all Italy the Celts were called Gauls.

23. The garrison which was stationed in this town has been thoroughly frightened.

24. From the town of Vesontio they will hasten by forced marches to the camp of the Germans.

\section{EXERCISE FOR ORAL TRANSLATION}

1. We are going into the country; from the country; from the country of the Helvetians.

2. We were at home. We were in the country. We were in the city.

3. From Rome. From-the-vicinity-of Rome. From the city of Rome.

4. To Vesontio. To-the-vicinity-of Vesontio. To the town of Vesontio.

5. In Vesontio. In the town of Vesontio. In the city of Athens.

6. In this part of Italy. In these places. In all Italy.

7. He went home. He went away from home. From this town. To that river.

8. Express in Latin "in" the places mentioned in the vocabulary given in 443.

9. Express in Latin "from" the places mentioned in the vocabulary given in 443.

10. Express in Latin "to" the places mentioned in the vocabulary given in 443 . 
443. VOCABULARY (for reference only)

Capua, -ae, f., Capua, a city of Italy Belgium, -ī, n., Belgium Atlanta, -ae, f., Atlanta, a city of Novum Eborācum, Novī Eborācī, n., Georgia

Alabāma, -ae, f., Alabama America, -ae, f., America Philadelphia, -ae, f., Philadelphia Virginia, -ae, f., Virginia Athēnae, -ārum, f. plur., Athens Syrācūsae, -ārum, f. plur., Syracuse Cūmae, -ärum, f. plur., Cumae, a city of Italy

Corinthus, -ì, f., Corinth, a city of Calēs, -ium, f. plur., Cales, a city Greece

New York

Delphī, -ōrum, m. plur., Delphi, a city of Greece

Cincinnātī, -ōrum, m. plur., Cincinnati

Mississippī, -ōrum, m. plur., Mississippi

Carthāgō, -ginis, f., Carthage, a city of Africa

\section{LESSON VI}

\section{ABLATIVE AND GENITIVE OF DESCRIPTION-VOCA- TIVE CASE}

444. REFERENCES:

1. Ablative of Description (Quality): 140-141. Cf. 144 .

2. Genitive of Description (Quality): 101-103.

3. Vocative Case : $59, a$.

445. EXERCISE FOR WRITTEN TRANSLATION

1. Orgetorix was (a man) of the greatest influence in his state.

2. Men of this kind were not often well disposed toward ${ }^{1}$ the Romans.

3. These territories were shut in by mountains of great height; . . by mountains great in height.

4. Those who went forth from home took with them a hundred days' grain.

5. A ten-foot wall was made by the soldiers who were in the city.

1 In with the accusative. 
6. The Roman soldiers easily moved (up) to the town a tower of great weight.

7. This Gaul was (a man) of huge $\operatorname{size}^{1}$ and great bravery.

8. You, Diviciacus, are (a man) of the highest honor.

9. But we consider your brother, Dumnorix, (a man) of very great influence; . . . very great in influence.

10. The enemy, Cassius, will be informed of all plans of this kind.

11. A twelve-mile wall separates this state from our province.

12. The Romans used to make hundred-foot towers.

13. Dumnorix was (a man) of great popularity and ill disposed toward ${ }^{2}$ the Romans.

14. Diviciacus, the brother of Dumnorix, was better disposed toward ${ }^{2}$ them.

15. These soldiers were (capable) of the greatest labor.

16. All Aeduans of all classes called Dumnorix their friend.

17. It is a three days' journey from this city to the town of Geneva.

18. From this wall stones of great weight were hurled by our soldiers.

19. In this place, my son, there was a ten days' delay.

20. The Germans were thought by our men to be men of the greatest bravery.

21. Why, Marcus, were you and your friend ill disposed toward us?

1 " of huge size of body."

${ }^{2}$ In with the accusative. 
22. We have given the sword to a general of great prestige; ... to a general great in prestige.

23. A general of the highest honor has been given the command of our army.

24. A general of so great diligence, who has soldiers of the greatest bravery, can defeat us.

\section{EXERCISE FOR ORAL TRANSLATION}

1. Give the vocative forms of : nauta, Mārcus, servus, puer, bellum, vir, cōnsul, māter, fĩlius, bonus, meus, Cassius.

2. Our chief is (a man) of very great influence.

3. Of all the Aeduans, Dumnorix was the greatest in influence.

4. A chief of this kind: a chief well disposed toward us.

5. He was (a man) with a small head.

6. A four days' journey; an eight days' delay.

7. A leader of the greatest valor; a leader great in valor.

8. Why, my son, do you stay in a town of this sort?

9. Your soldiers, Labienus, are (capable) of the greatest labor.

10. The distance between these towns is (a distance) of ten miles.

\section{LESSON VII}

\section{DIRECT QUESTIONS - INDIRECT QUESTIONS - SEQUENCE OF TENSES}

447. ReFERENCES :

1. Direct Questions : 214-217.

2. Indirect Questions : 251.

3. Sequence of Tenses : 242-246. 
448. Explanation:

Study carefully the following examples:

\section{Primary (Principal) Sequence}

Sciō, I know

Sciam, I shall know

Scīverō, I shall have known

quid faciās, what you are doing. quid fēceris, what you have done,

Secondary (Historical) Sequence

Sciēbam, I knew

Scīīi, I knew

Sciveram, I had known

quid facerēs, what you were doing. quid fēcissēs, what you had done.

\section{EXERCISE FOR WRITTEN TRANSLATION}

1 a. What are the Helvetians attempting?

b. Caesar learns what the Helvetians are attempting.

c. Caesar learned what the Helvetians were attempting.

2 a. Will Caesar move his camp?

b. Caesar will not move his camp, will he?

c. Will not Caesar move his camp?

3. The general saw where the enemy were, and knew where they were marching to.

4. This man will tell me how many soldiers he has and how large an army the enemy had.

5. Liscus knew with how great danger he had done this.

6. Caesar asked why they were not bringing him the grain.

7. He does not understand why the soldiers have not come.

8. Will you not find out who was leading those soldiers?

9. He inquired what each one of these men had said in the council. 
10. I had already explained why they were holding back the grain.

11. You will not tell him why I did this, will you?

12. Why did you tell him where the general had gone?

13. I shall easily learn who has tried this.

14. Did the general ask you where I was?

15. In the city where the army had encamped he learned where the enemy was.

16. The general will inquire where the enemy have gone.

17. I asked him how many cities he had captured.

18. The messenger told me why he was neglecting his duty.

19. No one knows where the army has been led.

20. Will he not inquire why the general was pitching camp in that place?

21. I found out why this had not been done.

22. He had asked me why they were not sending him soldiers.

23. We shall not tell him why we did this, shall we?

24. He asked me why I had not told the consul where you were.

\section{EXERCISE FOR ORAL TRANSLATION}

1. I am telling him where you are; . . . where you were.

2. He asked who had done this; ... who was doing this.

3. You will not fight, will you? Will you fight? Will you not fight? 
4. He knows why he was being sent; ... why he was sent; ... why he has been sent.

5. He was in the city whither we were being sent. He knew where we were being sent.

6. How large an army have you? I know how large an army you have. I knew how large an army you had.

7. Why were you doing this? Do you know why you were doing this?

8. In Rome; in Pompeii ; in Missouri ; in Philadelphia; in Pennsylvania; at home; in Cales (plur.).

9. From Mississippi to Cincinnati; from Alabama to Atlanta; from Athens to Rome.

10. A man of great prestige; a ten-foot wall; a three days' march.

\section{LESSON VIII}

TIME WHEN - TIME WITHIN WHICH - DURATION OF TIME-EXTENT OF SPACE

451. ReFerences :
1. Time When 169 .
3. Duration (Extent) of Time: 169.
4. Extent of Space : 199.

452. Explanations :

1. The accusative of duration of time indicates that the action took place and lasted for practically the whole period of time indicated.

2. The ablative of time within which indicates that the action took place at some point or points of time within the period indicated, but did not last throughout the entire period. 


\section{EXERCISE FOR WRITTEN TRANSLATION}

1. Caesar led his army for ten days through the territory of the Sequani.

2. On the third day they marched twenty-five miles, and at sunset arrived at Vesontio.

3. Within two months these nations will be conquered by Caesar.

4. On the arrival of Caesar's army the Helvetians sent ambassadors to him.

5. During that summer the army marched eight hundred miles.

6. During that night the soldiers remained in camp, but at daybreak they set out.

7. In the fourth watch the general sent forward scouts.

8. At that time Caesar had eight legions in Gaul.

9. In the summer this river is a hundred feet broad and eight feet deep.

10. On the following day the army set out at daybreak, and marched for five hours.

11. In the memory of our fathers the Gauls defeated us in several battles.

12. For many days they marched through these territories, and on the sixteenth day they arrived at Geneva.

13. The army remained in this city for three months.

14. In the fourth month they will go into the territory of the Gauls, where they will stay five days.

15. Within twelve days I shall lead you into the fields of the enemy. 
16. In the third watch the army set out and marched for six hours.

17. On the following day they broke camp and marched twenty miles.

18. At daybreak Caesar sent ahead scouts who learned where the enemy had gone.

19. In the summer of that year Caesar defeated the Helvetians in many battles.

20. During the night he led the soldiers into the city, where they stayed all night.

21. That wall was six feet high and two feet broad.

22. Next year we shall send an army into Gaul, which will remain there seven months.

23. At that time we were in Geneva, where we had gone during the first watch.

24. On the following day they arrived at the town (of) Vesontio, where they stayed several days.

\section{EXERCISE FOR ORAL TRANSLATION}

1. For ten days; within ten days; on the tenth day.

2. That day they remained in the city.

3. A road ten miles long and forty feet broad.

4. On that night during the fourth watch.

5. For three years; within three years.

6. You have often told me this. I was told this.

7. I told you why I was doing this ; ... why I had done this.

8. I asked him how many miles he had marched.

9. A leader of great prestige; a leader great in prestige.

10. The army has marched one hundred fifty miles. 


\section{LESSON IX}

\section{COMPARISON : ABLATIVE OF COMPARISON - DEGREE} OF DIFFERENCE

455. REFERENCES :

1. Ablative of Comparison : 157, 158. 3. Degree of Difference : 160-161.

2. Plūs, Minus, Amplius, Longius : 159. 4. Time Before or After : 174.

456. EXERCISE FOR WRITTEN TRANSLATION

1. During this year he remained a hundred days at Rome and less than three months at home.

2. The Gauls' territories are broader than the Germans'.

3. Our army used to make towers many feet higher than the fortifications which they were attacking.

4. Your speech, Divico, was bolder than your acts.

5. Two hours before daybreak we started from camp and that day proceeded twenty miles.

6. A few hours later they began battle not farther than ten miles from the town of Vesontio.

7. A little after sunset four thousand men set out from camp.

8. Their lands extended more than a hundred miles in width.

9. The fosse of this town was much wider than the rampart.

10. The greater the danger was the more boldly did these men advance.

11. This state has territories much broader than our province.

12. Two hours afterward many men were seen on the walls of this town. 
13. During the whole summer they marched more than jwenty miles every day.

14. The scout will give this message to the general more easily than to the soldiers.

15. They left villages and towns a little better than ' those which they now dwell in.

16. They always abandoned their hopes more easily than their fears.

17. Many years ago $^{1}$ this nation killed two thousand Roman soldiers.

18. One legion attacked forces much larger than the whole Roman army.

19. In one month they burned more than a thousand buildings and twenty towns.

20. This town was not more than a mile distant from the sea.

21. The Germans were much braver than the Gauls.

22. The greater were the forces which attacked the town, the more bravely did our soldiers defend (it).

23. The infantry fought more boldly than the cavalry.

24. We began battle at daybreak, and three hours later the enemy was defeated.

\section{EXERCISE FOR ORAL TRANSLATION}

1. The Rhine is much deeper than the Rhone.

2. We considered Caesar's soldiers a little braver than Pompey's.

3. The wall was not more than four feet in width.

4. More than ten towns were burned in one day. 
5. He stayed home less than three hours.

6. He told this more easily to the general than to the lieutenant.

7. Where have you seen a town larger than this?

8. Three days ago he set out from Rome.

9. I saw him many years ago.

10. Several hours after your arrival; a few hours before sunset.

\section{LESSON $\mathrm{X}$}

ADJECTIVES AS SUBSTANTIVES-POSSESSIVE ADJECTIVES-PERSONAL AND REFLEXIVE PRONOUNS

458. ReFERENCES:

1. Adjectives as Substantives : 3. 3. Reflexive Pronouns and Adjectives : 19.

2. Personal Pronouns : 16-18.

4. Pronouns and Possessives of the Third Person : 20.

459. Explanation:

It is important to distinguish between is, ea, id, the pronoun of the third person, meaning he, she, it, and is, ea, id, the adjective meaning this, that.

$\bar{E}$ ius cōpiās vìdī, I have seen his forces (the forces of him). $\boldsymbol{E} \bar{a} \boldsymbol{s}$ côpiās vìdi, I have seen those forces.

460. EXERCISE FOR WRITTEN TRANSLATION

1. Dumnorix always had about him a great number of horsemen.

$2 a$. I have heard many (things) about him, and his horsemen and their deeds.

b. I have heard many (things) about these horsemen.

3. He used to go forth from his own state and lead his horsemen with him. 
4. Caesar had led his (soldiers) into the country of the Aeduans and was defending them from their enemies.

5. The Aeduans had often intrusted themselves and all their (possessions) to the Romans and had been defended by them.

6. You, Crassus, will withdraw with all your (soldiers).

7. You will withdraw, but I shall neither withdraw nor surrender myself.

8. You, soldiers, will never surrender either yourselves or your town.

9. In a cavalry battle many of our (soldiers) were killed and the rest retreated.

10. The Aeduans have promised many (things), but all these (things) are now being held back by them.

11. By these (men) everything was handed over to our (men).

12. The ancestors of these (men) had always called us their allies.

13. Caesar called to him Diviciacus and learned from him many (things) about his brother, Dumnorix.

14. Diviciacus had been the most powerful man in his state.

15. By his ${ }^{1}$ help Dumnorix had increased his power and had become the most powerful man in this state.

16. The friends of Dumnorix fear Caesar greatly, for at his arrival they will lose their power.

17. All these (things) Diviciacus told Caesar about his ${ }^{2}$ brother and his ${ }^{3}$ friends. 
18. Caesar then called Dumnorix to him and told him everything.

19. I can defend myself and my (friends) from you and your horsemen.

20. Many (men) fear you, soldiers, but all (men) fear your general.

21. Everything which was reported about these (men) seemed to be true.

22. All who surrendered themselves and all their (possessions) to us were defended by our (soldiers).

23. These (men) will return to their city and tell their (friends) everything that our (soldiers) have done.

24. You, whose ancestors considered us (as) friends, are now joining with our enemies.

\section{EXERCISE FOR ORAL TRANSLATION}

1. I shall surrender myself and all my (possessions). Conjugate in the future indicative.

2. I have seen every one: I have seen many (things): I have seen many (men).

3. You, Caesar, and your (soldiers) have fought ${ }^{1}$ with this nation.

4. You, Romans, and your ancestors have fought with this nation.

5. He has betaken himself to this town; ... to his town; ... to their town.

6. I came with my friends. Conjugate in the perfect tense.

7. Caesar saw his soldiers. Caesar saw Labienus and his ${ }^{2}$ soldiers. 
8. I did not send the soldier to him; he called the ;oldier to him.

9. I have followed them and their soldiers.

10. They have followed their (own) soldiers.

\section{LESSON XI}

\section{ABLATIVE CASE: MANNER-CAUSE-ACCORDANCE}

462. ReFERENCES:

1. Manner : 131. 2. Cause : 135-136. 3. Accordance : 138-139. 4. Review the References of Lesson III.

463. Explanations:

1. When in doubt as to which of the ablative constructions applies in a given case, consider which of the following questions is to be answered:

The Ablative of Means or Instrument answers the question "By what?" "With what?"

The Ablative of Agent answers the question "By whom?"

The Ablative of Manner answers the question "How?"

The Ablative of Cause answers the question "Why?"

The Ablative of Accompaniment answers the question "With whom?"

The Ablative of Accordance answers the question "According to what?"

The Ablative of Specification answers the question "In what respect?"

2. Sometimes a preposition (ex or dē) is employed with the ablative of cause or the ablative of accordance. Learn the following phrases by heart:

Hāc dè causā, hāc dè rē, for this reason.

Quā dè rēe quā dē causā, quā rēe, for which reason, for this reason,

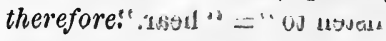




\section{EXERCISE FOR WRITTEN TRANSLATION}

1. Dumnorix had held back the grain, not by order of the state, but of his own accord. prestige.

2., The Aeduans had been influenced by his great

3. For this reason Caesar justly and deservedly wished to inflict punishment on Dumnorix.

4. Therefore he summoned Diviciacus to him.

5. According to his custom he spoke freely to him.

6. $\mathrm{He}^{1}$ listened to ${ }^{2}$ Caesar's speech with great sorrow.

7. For he was alarmed at his brother's danger.

8. Therefore with great eagerness he begged (for) his brother's life.

9. Caesar was influenced by the speech of Diviciacus, and because of his friendship freed his brother.

10. On the next day Caesar sent Labienus ahead with two legions.

11. Labienus marched with great speed and seized a certain mountain.

12. Then according to Caesar's order he awaited the arrival of our (men).

13. The general will lead the army with the greatest care.

14. According to their customs the Helvetians inflicted punishment on Orgetorix.

15. Diviciacus had aided the Romans with very great zeal.

1 ille.

2 "listen to " = " hear." 
16. Therefore Caesar saved Dumnorix because of the good will of his brother.

17. With the consent of our allies we shall call a council.

18. The army captured the town with the greatest difficulty.

19. Of my own accord I set out with these three legions.

20. With swords and javelins we made an attack on the enemy.

21. With four cohorts he set out from camp.

22. With the greatest speed they hastened into the territory of the enemy.

23. In accordance with your custom you will save the children.

24. I understand with how great danger you have done this.

\section{EXERCISE FOR ORAL TRANSLATION}

1. With courage; with great courage; with a sword.

2. Caesar's soldiers attacked the enemy with great zeal.

3. Caesar's soldiers fought with swords.

4. Caesar with his army marched into Gaul.

5. The Romans excelled the enemy in valor.

6. Of my own accord I punished him. Conjugate this sentence in the present indicative.

7. In accordance with the order of the general; in accordance with my order.

8. The Helvetians justly - unjustly - waged war with the Aeduans.

9. According to my custom; - your, his, etc.

10. For this reason we shall fight with difficulty. 


\section{LESSON XII}

\section{INDIRECT DISCOURSE: SIMPLE SENTENCES}

466. REFERENCES:

1. Infinitive in Indirect Discourse : 333.

2. Tense of the Infinitive in Indirect Discourse : $337-340$.

\section{Explanations:}

1. Direct Discourse gives the exact words of the speaker or writer. When a statement is not in the exact words of the speaker, but is put in the words of another or the same person after a verb of saying, etc., we have indirect discourse. Indirect discourse in English is usually introduced by the word "that." Quotation marks indicate that the exact words of the speaker are quoted, and therefore introduce direct discourse.

Direct Discourse : $\left\{\begin{array}{l}\text { The soldier is fighting. } \\ \text { He says, "The soldier is fighting." }\end{array}\right.$

Indirect Discourse: He says that the soldier is fighting.

In Latin no word like "that" in English is used to introduce indirect, discourse.

2. Tenses of the Infinitive. - The tense of the infinitive in indirect discourse in English follows a sort of sequence of tenses. In Latin the tense of the infinitive is determined by the tense that it would be in direct discourse.

Direct Discourse

INDIRECT Discourse

Indicative

Infinitive

'Present . . . . . . . . becomes . . . Present

IMPERFECT $\ldots$.

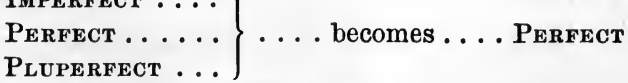

Future $\ldots \ldots \ldots\}$. . . . becomes.... Futurure

3. Do not confuse indirect discourse and indirect ques- 
tions. Indirect discourse is regularly introduced by "that" in English, while an indirect question is always introduced by some interrogative word.

I know that he is fighting, sciō eum pāgnāre. (Indirect Discourse.) I know why he is fighting, sciō cur pügnet. (Indirect Question.)

\section{EXERCISE FOR WRITTEN TRANSLATION}

1 a. Labienus is holding the mountain.

$b$. We know that Labienus is holding the mountain.

c. We knew that Labienus was holding the mountain.

2. But Considius reports that the enemy have seized the mountain.

3. He said that he had caught sight of the arms of the enemy.

4. Late in the day Caesar learned that Labienus was waiting on the mountain.

5. At that time the scouts informed him that the enemy had moved their camp.

6. Caesar thought that he would not receive his grain supply.

7. Therefore we hear that he turned his (line of) march away from the Helvetians.

8. It was reported to the enemy that he was departing through fear.

9. Therefore we hear that they began to follow Caesar's army.

10. Caesar learned why the enemy were following him, and accordingly drew up his line of battle.

11. Caesar shows that the Helvetians fought bravely, but were overcome. 
12. After the battle the enemy said that they were willing to surrender to him.

13. We all know that the Gauls will fight bravely.

14. Caesar says that the Romans defeated the Helvetians with great difficulty.

15. I hope that we shall easily drive the enemy out of the province.

16. He thinks that the Helvetians were marching through the territory of the Sequanians.

17. Caesar was informed by scouts that the enemy had pitched camp at the foot of a mountain.

18. Labienus did not know what Considius had reported to Caesar.

19. The Helvetians thought that Caesar would not pursue them.

20. I heard that the general was drawing up his troops in that place.

21. This soldier reported where the enemy were stationing their troops.

22. Caesar thought that their neighbors would send aid to the Helvetians.

23 $a$. We have found out that the leader is dismissing the council.

b. We have found out why the leader is dismissing the council.

24. I heard that the enemy were not able to withstand our attacks.

\section{EXERCISE FOR ORAL TRANSLATION}

1. The enemy is withdrawing. Put this into indirect discourse after all tenses of "I learn." 
2. The enemy was withdrawing. Put this into indirect discourse after all tenses of "I say."

3. The enemy will withdraw. Put this into indirect discourse after all tenses of "I know."

4. The enemy has been defeated. Put this into indirect discourse after all tenses of "I hear."

5. The enemy is being defeated. Put this into indirect discourse after all tenses of "I think."

6. Where is the army? I ask where the army is. I asked where the army was.

7. I know what you want. I know that you want aid.

8. Whom has he sent? I know whom he has sent. I knew whom he had sent.

9. I am retreating. Conjugate this in the present tense.

10. He did this of his own accord; ... with great zeal ; . . with zeal ; . . . at the order of the general.

\section{LESSON XIII}

\section{ACCUSATIVE WITH COMPOUND VERBS - INNER OBJECT}

470. ReFERENCES:

1. Accusative with Compound Verbs : $62,63 \mathrm{~N}$.

2. Accusative of the Inner Object: 65 .

3. Multum Possum (Valeō), etc.: 66.

\section{Explanation:}

The accusative of the inner object is frequently used with the following verbs with somewhat idiomatic translation:

cōnor, attempt, make an attempt respondeō, reply, make a reply sentiō, think, hold an opinion quaerō, inquire, make inquiry moneō, warn, advise, give advice postulō, demand, make a demand polliceor, promise, make a promise. 
Idem cōnātur, he is making the same attempt, he is attempting the same (thing).

Idem monet, he is giving the same advice, he is advising the same (thing).

$\boldsymbol{H} \bar{o} c$ postulat, he makes this demand, he demands this.

\section{EXERCISE FOR WRITTEN TRANSLATION}

1. Caesar made many inquiries from the ambassadors of the Gauls who had come to him.

2. He learned how many Germans Ariovistus had led across the Rhine.

3. Diviciacus informed him that the Germans had crossed the Rhine in accordance with the wish of the Sequanians.

4. Caesar then made the same inquiries from the Sequanians themselves.

5. At first they made no reply, ${ }^{1}$ but finally spoke these (words).

6. Many Germans crossed the Rhine a few years ago and waged war for us with our neighbors.

7. Those Germans have settled in our fields and now a greater multitude is being led across the river.

8. By their help we are more powerful than our neighbors.

9. But now these Germans hold our best fields and are more powerful than we (are).

10. In a short time a greater band will be led across the Rhine.

11. This warning we give to you $^{2}$ and the Roman people. ${ }^{2}$ 
12. These Germans whom we invited into Gaul will soon try to cross the Rhone.

13. Caesar held the same opinion and therefore made this inquiry from Ariovistus.

14. Why do you not lead your troops across the Rhine into Germany?

( 15. Ariovistus made this reply: "I have crossed the Rhine and will remain in Gaul."

(16. The Gauls often surrounded the merchants and made many inquiries from them.

17. To these the merchants always made some reply.

18. In the battle near Vesontio the Germans almost surrounded our (soldiers).

19. Two new legions crossed the river with great speed. 120. The Roman soldiers heard that the Germans were very powerful in war.

21. Those tribes which were least powerful were often defended by Caesar.

22. The one band has almost surrounded the town, the other has withdrawn.

1 23. A few have already crossed the river and the rest will make the same attempt.

124. We have made many promises to the soldier who crosses $^{1}$ the river.

\section{EXERCISE FOR ORAL TRANSLATION}

1. The army has crossed the river.

2. He has led the army across the river. The army has been led across the river. 
3. Many soldiers stand around the general.

4. They surround the town with their troops.

5. He has made these inquiries of us, but we have made no answer.

6. We shall try to cross the river. He will make the same attempt.

7. I make you ${ }^{1}$ this promise.

8. We hold the same opinion about this affair.

9. The one had very little power, the other was the most powerful in his state.

10. Now he has less power than you. In a few years he will have more power than you.

\section{LESSON XIV}

DATIVE WITH SPECIAL VERBS-DATIVE WITH COMPOUND VERBS

474. ReFERENCES :

1. Dative with Special Verbs: 79-80.

2. Dative with Compound Verbs : 83,84 .

475. Explanations :

1. Not all verbs compounded with prepositions take the dative case according to 83 .

a. Many compound verbs take the accusative case according to 62 .

$b$. So also many other compound verbs take the accusative case. Examples are:

cōnferō, bring together, betake importō, bring in, import interficiō, kill obtineō, hold

2. Certain compound verbs take both an accusative 
of the direct object and a dative of the indirect object. Examples are:

praeficiō, put in charge of inferō (bellum), make war on

3. In certain compound verbs the prefix is purely adverbial and does not affect the construction. Examples are:

conveniō, come together, assemble prōcēdō, proceed

4. In the sentences which follow, certain compound verbs should take the accusative. They are:

$\begin{array}{lll}\text { adiuvō, help } & \begin{array}{l}\text { opprimō, crush } \\ \text { obtineō, hold }\end{array} & \begin{array}{l}\text { occupōo, seize } \\ \text { contineō, hold in }\end{array}\end{array} \quad \begin{aligned} & \text { conō, call together }\end{aligned}$

\section{EXERCISE FOR WRITTEN TRANSLATION}

1. The ambassadors, who had come from many parts of Gaul, said that they trusted Caesar.

/2. "You, Caesar, have greatly helped us, for you have made war on our enemy."

3. You have crushed an enemy whom we could not resist.

4. You have looked out for many states that have trusted you.

5. A greater calamity has now befallen us, for the Germans have crossed the Rhine.

6. They have seized our fields and are now ruling us.

(7. A chief named Ariovistus is in command of the Germans.

8. He already holds many states and desires command of all Gaul.

[9. The speech of the ambassadors easily persuaded Caesar. 
10. He accordingly sent this message to Ariovistus: "The Roman people have put me in command of six legions."

11. With these legions I shall make war on all who harm our allies.

(12. Ariovistus replied: "Caesar speaks boldly because he has never met the Germans."

[13. I shall not harm the Romans if they keep themselves in their part of Gaul.

14. But why do they try to instruct me about the command of my (part of) Gaul?

| 15. Caesar replied to Ariovistus, (saying) that he would make war on him.

16. He provided at once for the grain supply and started for Vesontio.

17. Caesar's soldiers had always before this time obeyed him.

18. But at Vesontio they did not wish to obey him on account of their fear of the Germans.

19. Caesar therefore called them together and persuaded them by a speech.

20. Was I not in command of that army which crushed the Helvetians?

21. Did not these same Helvetians often resist the Germans whom you now fear?

22. The soldiers of the tenth legion will obey me and advance against the Germans.

23. Caesar always especially trusted the tenth legion.

24. Will the rest stay at Vesontio and resist the Germans without a commander? 


\section{EXERCISE FOR ORAL TRANSLATION}

1. You cannot persuade me, for I do not believe you.

2. He is in command of the army, and he will crush the enemy.

3. We have put him in charge of the army.

4. He will not obey us.

5. He is in command of soldiers who do not trust him.

6. They resisted us, but we have crushed them in battle.

7. I shall not harm those who meet me.

8. He is making war on my enemies. War is being made on my enemies.

9. My enemies are waging war with me.

10. He had everything that he desired.

\section{LESSON XV}

\section{PURPOSE CLAUSES - RESULT CLAUSES}

478. REFERENCES :

1. Purpose Clauses : 253-254. 2. Relative Clauses of Purpose : 255.

3. Result Clauses : 258-259.

479. Explanations :

1. Purpose and Result Clauses. - Notice the difference in the use of the subordinate clauses in the following examples :

Purpose : $\left\{\begin{array}{l}\text { Our ancestors fought bravely that they might be free. } \\ \text { Māiōrēs nostrī fortiter pūgnāvērunt ut lïberī essent. }\end{array}\right.$

RESULT : $\left\{\begin{array}{l}\text { Our ancestors fought so bravely that they were free. } \\ \text { Māiōrēs nostrī tam fortiter pūgnāvērunt ut lỉberī essent. }\end{array}\right.$

Purpose looks forward to the accomplishment of an action. Result shows that action accomplished. 
2. Notice the negative used in the subordinate clauses: $\mathbf{n} \bar{e}$ is always used in the negative purpose clause; ut ... nōn is the negative of a result clause.

\section{EXERCISE FOR WRITTEN TRANSLATION}

1. Ariovistus sent ambassadors to Caesar to demand a conference.

2. These ambassadors went with so great speed that they arrived at ${ }^{1}$ Caesar's camp within a few hours.

3. In order to persuade Ariovistus, Caesar said that he would confer with him.

4. But in order that he may not be in danger, he leads with him the tenth legion.

5. The soldiers of this legion went on horseback ${ }^{2}$ so that Caesar had a guard of cavalry.

6. In the conference Ariovistus spoke so boldly that Caesar could not endure his speech.

7. At the same time the cavalry of Ariovistus attacked Caesar's soldiers so that Caesar withdrew.

8. In order that a battle might not be begun, Caesar led his legion back into camp.

9. Again ambassadors came from Ariovistus to Caesar to speak with him.

10. Caesar sends Procillus and Mettius to hear Ariovistus's speech.

11. But Ariovistus held them (as) captives in camp so that they were not able to return to Caesar.

12. On the same day Ariovistus moved his camp so that he might cut Caesar off from his supplies. 
13. In order to overtake the Helvetians, Caesar had led his army across the river.

14. The bravery of the Germans is so great that they are conquering all the tribes of Gaul.

15. Their army is so great that the Aedui cannot resist them.

q 16. We shall send ahead our horsemen to pursue the enemy.

17. In order that he might not be cut off from his supplies, Caesar moved his camp.

18. In this region the Romans remained five days to await the coming of the cavalry.

q 19. The soldiers fought with so great zeal that the enemy could not withstand their attack.

20. Caesar will winter in this region in order to have a supply of grain.

21. You had not yet sent men to aid our enemies.

22. Our (men) attacked so fiercely that the enemy fled.

23. They fled with so great speed that our (men) could not overtake them.

24. This river is so deep that we cannot cross it without boats.

\section{EXERCISE FOR ORAL TRANSLATION}

1. He does this to defend himself.

2. He delays in order not to fight.

3. The Romans fight so bravely that main verb to the enemy are overcome. 4. We are attacking so quickly that the indicative.
they cannot flee.

Change the all tenses of 
5. They are sending soldiers to attack us. Translate in two ways.

6. Change the tense of the verb "send" in sentence 5 to all tenses of the indicative and translate, using a relative clause of purpose.

7. Labienus is in command of the tenth legion. Labienus has been put in charge of the tenth legion.

8. I think that he will come to us. He says that he will come to us.

9. We cannot make an attack on the enemy. Translate in the active and then change into the passive.

10. Caesar led his army across the river. His army was led across the river.

\section{LESSON XVI}

\section{DATIVE CASE : REFERENCE - PURPOSE}

482. REFERENCES :

1. Reference (Interest, Person for Whom): 87.

2. Purpose (Service, Thing for Which) : 90-91.

483. Explanations :

The dative of purpose is frequently to be used in Latin where the English construction is somewhat different. Thus the Latin dative of purpose may take the place of the following constructions in English :

1. A predicate noun or appositive with "as."

They came as a reinforcement to us, nōbīs subsidiō vēnērunt.

They are a help to us, nōbis auxilio sunt.

2. A predicate adjective.

This was useful (= for a use) to the general, hōc imperātōrī $\bar{u} s u \bar{e}$ erat.

3. A purpose infinitive.

They came to guard us (for a guard to us), nōbīs praesidiō vēnērunt. 


\section{EXERCISE FOR WRITTEN TRANSLATION}

1. A spot about six hundred paces from the enemy was chosen for a carrp.

2. There Caesar left two legions as a guard for the camp.

3. He set the following day for battle, but Ariovistus did not attack.

4. For delay was advantageous to the Germans.

5. Many tribes were coming to aid the Germans daily.

f 6. On the day after this Caesar left a few cohorts to protect both camps.

7. Then he appointed lieutenants for all the legions.

8. The Germans came forth from camp, and Caesar gave the signal for battle.

9. The Romans attacked with so great speed that javelins were a hindrance to the enemy.

(10. But their swords were of great use, and they pressed the Romans hard on the right wing.

( 11. Then Crassus sent his cavalry as a reinforcement to our men.

12. Thus the Germans were conquered and sought safety for themselves in ${ }^{\mathbf{1}}$ flight.

13. The cavalry of the Gauls had often been a help to Caesar.

14. Ariovistus has chosen this place for his soldiers.

15. Caesar gave a shield to the soldier as a reward.

16. The cavalry is coming to reinforce the infantry. 
17. The baggage was a great hindrance to the legions on the march.

18. The tenth legion acted ${ }^{1}$ as a ford to the rear (of the army).

19. Caesar had appointed a day for the conference.

20. The wrongs of the Gauls will be a-matter-for-consideration $^{2}$ to Caesar.

21. I shall choose a general for you who will lead you to victory.

22. The consul will leave a part of his army to guard the citizens.

23. That bridge was of ${ }^{3}$ great advantage to the Romans.

24. The Aeduans sent cavalry to Caesar's aid.

\section{EXERCISE FOR ORAL TRANSLATION}

1. That cohort was a protection to me; ... to you, etc.

2. I have chosen a place for the camp; ... for winter quarters; . . . for the battle; . . f for a town; . . . for a city.

3. What do you want (for yourself)? What does he want? etc.

4. He sent men to aid us. Give in three ways.

5. I shall do this for myself; ... for you, etc.

6. That is useful to me; ... to you, etc.

7. He has sent men to guard the city;... to aid the soldiers ; ... to reinforce the cavalry.

8. Caesar had put Labienus in charge of the legions on the left wing.

9. This general was placed in charge of the whole army of the Romans.

10. I cannot believe those who harm me. 


\section{LESSON XVII}

\section{SUBSTANTIVE CLA औैSES OF PURPOSE AND RESULT - INDIRECT REFLEXIVE}

486. REFERENCES :

1. Substantive Clauses of Purpose : 261-263.

2. Substantive Clauses of Result : 264 .

3. Indirect Reflexives : 21-23.

487. Explanation:

A reflexive pronoun or adjective is used in the infinitive clause in indirect discourse referring to the subject of the main verb of saying. This is the "indirect reflexive." In the same way the indirect reflexive may stand in a substantive clause of purpose referring to the subject of the main verb.

Dux minlitjorus imperāvit $\mathrm{n} \overline{\mathrm{e}}$ s $\overline{\mathrm{e}}$ sequerentur, the general ordered the soldiers not to follow him.

\section{EXERCISE FOR WRITTEN TRANSLATION}

1. The chiefs of the Belgians had persuaded their states to form a conspiracy against the Romans.

2. They had advised their (countrymen) not to await the arrival of the Roman army.

3. "Other states," they said, "delayed, and the result is that they are now held in slavery."

4. Caesar immediately employed the neighboring states to inform him about this conspiracy.

5. Meanwhile he enrolled two new legions and ordered a certain lieutenant to lead them into farther Gaul.

6. He had instructed his other lieutenants not to delay longer in winter quarters. 
7. And so it happened that the Belgians could not fortify their towns before the arrival of our soldiers.

8. The Remi advised Caesar not to begin battle with all the Belgians at one time.

9. The result was that Caesar tried to divide the enemy into many bands.

10. This was his plan, to wage war with the states of the Belgians one at a time.

11. He made his allies advance into the territories of the Belgians and lay waste their fields.

12. Meanwhile he saw to it that the enemy should not shut him off from his supplies.

13. Caesar pitched camp on-the-other-side-of 1 the Axona, and the result was that they could not attack him from the rear.

14. Added-to-this-was-the-fact that he had fortified his camp on both sides.

15. These fortifications made it impossible for the enemy ${ }^{2}$ to surround the Romans on the sides.

16. The result was that the enemy did not make an attack on the camp.

17. But the Belgians urged their leaders to cross the Axona and seize the supplies of the Romans.

18. Caesar had instructed Titurius, who was on the other bank, to resist the enemy.

19. The result was that few of the Belgians reached the other bank.

20. Caesar had ordered certain men to lay waste the fields of the Belgians. 
21. Meanwhile the Belgians who had heard of this begged their chiefs to lead them home.

22. They started in no fixed order, a circumstance which ${ }^{1}$ made them seem to be fleeing.

23. Caesar therefore ordered his cavalry to pursue the enemy all day and return at sunset.

24. It was a custom of the Roman cavalry to return to camp at sunset.

489. EXERCISE FOR ORAL TRANSLATION

1. He ordered me to follow him. Translate twice, using imperō and iubēo.

2. You ordered me not to follow him.

3. The result was that I obeyed neither.

-4. He orders me not to remain longer.

5. It happens that I do not wish to remain longer.

6. The general always makes the soldiers fortify the camp.

7. He has employed us to inform him about the enemy.

8. It is a custom of the Romans to defend their allies.

9. He has advised us to enroll two new legions.

10. The result is that we now have six legions.

\section{LESSON XVIII}

\section{INFINITIVES}

490. REFERENCE:

1. Subjective Infinitive : $323,325,1,2,3$.

2. Complementary Infinitive : 328-330.

3. Objective Infinitive : 331-332. 


\section{EXERCISE FOR WRITTEN TRANSLATION}

1. The Belgians were unwilling (for) a Roman army to be led into their territory.

2. Therefore they began to conspire against the Romans.

3. At first it was difficult to learn whether the rumors concerning the conspiracy were true.

4. Caesar had ordered certain Gauls to inform him (of) what the Belgians were doing.

5. Meanwhile it seemed best to enroll two new legions in hither Gaul.

6. Then he hastened to set out to the land of the Belgians.

7. The Remi, the nearest of the Belgians, were prepared to surrender themselves.

8. We ought ${ }^{1}$ not to consider this nation unfriendly.

9. For they begged that it be allowed them to help the Romans in every way.

10. Caesar seemed to believe them, but he compelled them to give hostages.

11. Afterward he allowed them to help him in many ways.

12. They informed him about the number of Belgians who were said to be in arms.

13. Caesar determined to inflict punishment on this nation for their wrongdoings.

14. Soldiers of so great courage ought ${ }^{1}$ not to fear this nation.

1 Write twice, using dēbeō and oportet. 
15. Our commander has ordered us to put an end to the battle.

16. The enemy seems to have set out for home.

17. The soldiers did not dare to proceed farther from camp.

18. They ought ${ }^{1}$ not to proceed so far without a leader.

19. We cannot tell why our soldiers were unwilling to make this attempt. ${ }^{2}$

20. To the Romans all the Germans seemed to be barbarous men.

21. He seems to have spoken a long while, but to have said nothing.

22. In this very spot two armies are said to have been defeated.

23. He does not hesitate to do that which no one has dared to attempt.

24. That nation which has surrendered ought ${ }^{1}$ not to flee.

\section{EXERCISE FOR ORAL TRANSLATION}

1. They are unwilling to be soldiers.

2. They prefer to be generals.

3. It is easy to begin battle ; to conquer is difficult.

4. He ought to be a soldier. Use oportet and conjugate in the present.

5. It pleases me to stay in Rome.

6. He tried to be brave in battle.

7. He has ordered me to help him. Translate twice, using iubē̄ and imperō.

1 Write twice, using dēbeō and oportet.

2 "attempt this." 
8. I asked that it be allowed me to remain. Conjugate in each person of this tense.

9. I ask to be allowed to remain. Conjugate in each person of this tense.

10. He did not allow me to be a soldier.

\section{LESSON XIX}

\section{PARTITIVE GENITIVE-PARTITIVE ADJECTIVES -} ALIUS AND ALTER

493. REFERENCES:

1. Partitive Genitive : $104-105,107$. 3. Partitive Adjectives : 108.

2. Ablative for Partitive Genitive : 106. 4. Alius and Alter : 56.

494. Explanations:

1. Learn carefully the list of words in $\mathbf{1 0 5}$ which take the partitive genitive.

2. Learn carefully the list of partitive adjectives in 108.

3. Note particularly the usage of mille, a thousand, and milia, thousands.

When speaking of one or $a$ thousand, use mille as an indeclinable adjective modifying its noun. When speaking of more than one thousand, use milia as a neuter noun of the third declension followed by the partitive genitive.

$A$ (one) thousand men, mille hominēs.

Two thousand men (two thousands of men) duo milia hominum.

Decline both of these examples.

4. The apparently very idiomatic uses of alius and alter arise from the desire not to repeat the same word in Latin. Thus remembering the double meanings of alius (one... another) and alter (the one... the other) when used in pairs, a literal translation of 
One went in one direction, another (went) in another becomes in Latin,

alius aliam in partem iit (alius aliam in partem iit), and the repeated words are omitted.

\section{EXERCISE FOR WRITTEN TRANSLATION}

1. The nation of the Bellovaci was by far the greatest of the Belgians.

2. Therefore Caesar preserved all of them, but demanded six hundred hostages.

3. The Nervii were neighbors of the Bellovaci and had many thousand soldiers.

4. They allowed no wine and other things to be imported into their territory.

5. Caesar marched into their territory and encamped about ten miles from them on the top of a hill.

6. Several of the Belgians had marched along with Caesar.

7. Certain (ones) of these reported the manner of the march of our army to the Nervii.

8. They showed that there was a large amount of baggage between the legions.

9. They said that it was no task to overcome the first legions.

10. But Caesar changed his line of march and sent six of his legions ahead.

11. The rest of the legions he placed behind the baggage.

12. The enemy made an attack, but were driven some in one direction, some in another. 
13. Two legions guarded ${ }^{1}$ the rear : one was the thirteenth, the other the fourteenth.

14. Some of the Nervii were killed, others were captured, others fled.

15. The attack of the enemy prevented a large part of these things.

16. On that day he marched twenty-five miles through the middle of the territory of the enemy.

17. Caesar did not have enough troops. He did not have enough grain.

18. The Nervii did not know what plan Caesar had adopted.

19. How much grain did the soldiers carry with them?

20. Caesar sent a thousand soldiers to fight with three thousand Gauls.

21. This tribe is the most powerful of all the Germans.

22. A large part of them was captured by Caesar's soldiers.

23. Certain of the soldiers had been left as a guard for the camp.

24. One of us will remain, the other will go with you. 496. EXERCISE FOR ORAL TRANSLATION

1. A part of us; all of us; a few of us.

2. Enough boats; no grain ; so much of the city.

3. Many men ; many of the men ; certain of the men.

4. The one aids the other. Some aid others.

5. Some in one place, others in another.

6. Other men; the other man; the other men.

7. A thousand ships; three thousand ships. 
8. Each of you ; which of you? many of you.

9. Decline mîlle passūs, a mile; tria mīlia passuum, three miles.

10. In the first part of the day; on the top of the wall ; in the midst of the town.

\section{LESSON XX}

THE DATIVE WITH ADJECTIVES - THE GENITIVE WITH ADJECTIVES

497. ReFERENCES :

1. Dative with Adjectives : 92 . 2. Genitive with Adjectives : 113-114.

498. EXERCISE FOR WRITTEN TRANSLATION

1. The spot where the army had been drawn up was not suitable for a battle.

2. The soldiers of the tenth legion were stationed opposite the Atrebates.

3. Next to the tenth legion were the soldiers of the ninth legion.

4. In valor the soldiers of the ninth legion were not equal to the soldiers of the tenth. affairs.

5. Nevertheless they were very skillful in military

6. All of the Roman soldiers were eager for ${ }^{1}$ battle.

7. The Nervii were neighbors to the Atrebates, and were like the rest of the Belgians.

8. They were friendly to the Gauls, but were hostile to the Romans.

9. They were equal to the Romans in valor, but were unskilled in war.

10. The camp is full of soldiers who are hostile to us. 
11. Ariovistus had been desirous of royal power.

12. The neighbors of the Nervii were like them in bravery.

13. Caesar chose a place suitable for a camp which was about ten miles from the enemy.

14. The Belgians are nearest to the Germans who live across the Rhine.

15. Considius was considered very skillful in military affairs.

16. The Aeduans had always been very friendly to Caesar and the Romans.

17. These barbarians were ignorant of the custom of the Romans.

18. The neighbors of the Aeduans were unfriendly to them.

19. The whole city is full of our friends and neighbors.

20. The arms of the Roman soldiers are unlike the arms of the Gauls.

21. On the hill opposite this city thousands of the enemy were drawn up.

22. The departure of the enemy was like flight.

23. The enemy whom we have conquered are now eager for peace.

24. Caesar had stationed his troops in a spot which was suitable for winter quarters.

\section{EXERCISE FOR ORAL TRANSLATION}

1. A man skilled in all things; . . . unskilled in all things.

2. A region neighboring on the territory of the Germans. 
3. These men are friendly to us. They are our riends.

4. That chief was my enemy. He was unfriendly to me.

5. A man desirous of war; of peace; of aid; of friendship.

6. A camp near the woods; near the river; near the city.

7. In a spot opposite the camp; opposite the hill; opposite the winter quarters.

8. It is not easy to cross this river. He orders us to cross this river.

9. The larger part of the city; in the middle of the city; all of the city.

10. We killed some in one place, others in another.

\section{LESSON XXI}

\section{GERUND - GERUNDIVE-SUPINE IN - UM}

500. ReFERENCES :

1. Gerund as a Verbal Noun : 376.

2. Gerundive as a Verbal Adjective : 377.

3. Gerundive Construction : 378-379.

4. Gerund or Gerundive expressing Purpose : 381.

5. Supine in -um : 390 .

6. Summary of Purpose Constructions : 257.

7. Cf. Lesson XVI, Explanations.

\section{Explanations :}

1. In English we have a verb form in -ing which is equivalent to a noun; that is, it may be used as the subject or object of a verb or after a preposition. This form in -ing is called in English a "verbal noun," "gerund" or 
"infinitive in -ing." In Latin it is called a "gerund." Examples are:

Running is exercise. He gets exercise by running. He enjoys running. $\mathrm{He}$ is tired of running. He was punished for running.

In Latin the gerund is similarly used except that it is replaced by the infinitive as subject in the nominative case. Cf. 376.

2. In English the gerund often takes an object. Where the English gerund takes an object, the Latin prefers the use of the gerundive. Cf. 377. The Latin gerundive then has the case that the Latin gerund would have if used; but the gerundive agrees with its noun in gender, number, and case.

English gerund with object:

Latin gerund with object:

A plan of capturing the cities.

Latin gerundive construction : Cōnsilium urbium capiendārum.

The gerundive construction is much preferred and is required after prepositions and in the dative case. Hence the gerund with an object is rare except in the genitive or ablative case.

3. Form the gerund and gerundive of : laudō, habeō, dūcō, rapiō, mūniō.

\section{EXERCISE FOR WRITTEN TRANSLATION}

1. The Aduatuci had come with all their forces to help the Nervii.

2. They were prepared to fight and had come for the purpose of fighting for their kinsmen, the Nervii.

3. The Aduatuci were desirous of waging war, but they quickly put aside the plan of fighting with the Romans. 
4. For they had no hope of defeating a nation which had defeated the powerful Nervii.

5. Therefore they adopted the plan of returning home and defending their towns. 428,

6. The town of the Aduatuci was not to be captured without great effort.

7. For the purpose of capturing this town, the Romans were willing to undergo great toil.

8. Therefore they prepared everything which had to do with attacking a town.

9. A few days was sufficient for constructing the towers which were useful for the siege.

10. In order to avoid the weapons of the enemy the Romans constructed towers far from the town.

11. Meanwhile the Aduatuci kept saying: "Those towers of yours are not to be feared."

12. "You are very skillful in hurling javelins if you can throw them so great a distance."

13. A certain Roman shouted out: "Talking is easy, but you cannot defend your town from us by talking."

14. "In a short time you will adopt a different ${ }^{1}$ style of speaking."

15. The Romans were skillful in moving their towers (up) to the walls of a town.

16. And so the towers which had seemed not to-befeared were soon touching the walls.

17. Then the Aduatuci sent envoys to confer about terms of surrender. 
18. These men implored Caesar to grant them the privilege of retaining their arms.

19. Caesar advised them to put aside all hope regarding the retaining of their arms.

20. The Aduatuci had no reason for delaying longer, and so they surrendered.

21. We were ready to set out because we had hope of seizing broader fields.

22. We shall not be given an opportunity of making a journey through their fields.

23. Neither army was willing to make a beginning of crossing this river.

24. They chose one general to accomplish all these things. Write in five ways.

\section{EXERCISE FOR ORAL TRANSLATION}

1. Ariovistus is sending an army to fight with us. Give in five ways.

2. He has made a beginning of storming the town; ... towns.

3. He has made a beginning of storming the city; ... the cities.

4. He has made an end of speaking.

5. Those troops of yours are not greatly to-be-feared.

6. He has been given the privilege of speaking.

7. We shall conquer not by fighting, but by delaying.

8. Sufficient time was not given for carrying out these things.

9. He was desirous of speaking; ... of hearing the speech.

10. By fleeing, they escaped the danger. 


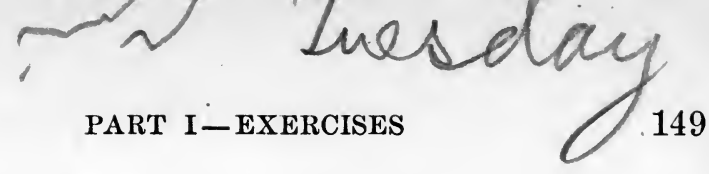

\section{LESSON XXII}

\section{POSSESSIVE GENITIVE - PREDICATE GENITIVE- DATIVE OF THE POSSESSOR}

504. ReFERENCES :

1. Genitive of Possession : 97, 100. 3. Predicate Genitive : 100, 109.

2. Possessive Adjectives: 98.4 4. Dative of the Possessor: 85-86.

505. EXERCISE FOR WRITTEN TRANSLATION

1. The German horsemen have small horses. ${ }^{1}$

2. Those small horses which you see are the German horsemen's.

3. It is your (duty), Considius, to carry these letters to the commander.

4. To look out for the safety of the army is not your (duty), but the general's.

5. This task $\mathrm{k}^{2}$ is (one) of great danger, nevertheless I shall undertake it.

6. It is the consul's (duty) to keep all the citizens unharmed.

7. The opinions which the centurions expressed were almost all of this kind.

8. In the beginning of the speech Caesar mentioned his (own) and the senate's favors toward Ariovistus.

9. The Belgians' and Gauls' method-of-attack was the same.

10. They came to discuss with him about their safety and (the safety) of all.

11. The arms and standards of the Gauls differ greatly from ours. 
12. All these fields, which extend a hundred miles, are the Germans'.

13. The fields across the Rhine are the Germans', but the Germans also have fields and homes in Gaul.

14. Caesar removed from sight his own and his lieutenants' horses.

15. "This part of Gaul is not the Roman people's, but mine," replied Ariovistus.

16. It is an eight days' journey from the land of the Germans to our province.

17. Caesar seemed to think that Gaul was not the Gauls', but his.

18. This nation cannot defend its own towns, yet they want to seize their neighbors' towns.

19. All the centurions which Caesar had were experienced in war.

20. Those centurions who are so skillful in military affairs wẻre Caesar's.

21. Caesar used to write letters to the Roman senate about his and his army's victories.

22. The women who had children at home begged Caesar to defend them.

23. Certain soldiers had neither shields nor swords during the whole battle.

24. The town has many defenders, nevertheless we no longer have any hope of defending (it).

\section{EXERCISE FOR ORAL TRANSLATION}

1. The Germans have towns across the Rhine. Use the dative of the possessor and give in all tenses of the indicative. 
2. Those towns were the Germans'.

3. You have lands in Gaul. $\left\{\begin{array}{l}\text { Use the dative of the pos- } \\ \text { sessor, and give in all } \\ \text { persons of the tense in- } \\ \text { dicated. }\end{array}\right.$

5. They have left their (own) towns.

6. They are seizing their neighbors' towns.

7. These lands are the Gauls', not ours.

8. Each one looked out for his (own), not the army's safety.

9. It is your (duty), soldiers, to defend us.

10. These towns are not yours, Caesar; you have towns in Italy.

\section{LESSON XXIII}

CUM-CLAUSES : TEMPORAL, CAUSAL, CONCESSIVE 507. References :

1. Cum Temporal: $277,278 . \quad 3$. Cum Concessive: 315.

2. Cum Causal : 292 . 4. Order of Words: 421.

\section{EXERCISE FOR WRITTEN TRANSLATION}

1. When the Belgians had been defeated and the Germans had been driven out, Caesar decided to set out for Illyricum.

2. But when he was preparing to go, a sudden war arose in Gaul.

3. The Veneti had begun this war during the winter when the Roman ambassadors were in their power.

4. Since he did not dare to neglect this wrong, Caesar returned again into Gaul.

5. When he arrived in the territory of the Veneti, they were already preparing to defend their towns. 
6. Since they had very many boats, it was very difficult to subdue them.

7. But although he had few boats, Caesar prepared to carry on war with them.

8. When he had collected as many boats as possible, he began to attack their towns and islands.

9. Although he captured many of their towns, he could not at first conquer the Veneti themselves.

10. Finally, however, when he had captured a great number of their ships, they surrendered.

11. When their ships are captured, ${ }^{1}$ the enemy will not be able to defend their towns.

12. Since the Veneti have been defeated, we shall go into winter quarters in this maritime state.

13. Although there were these difficulties of waging war, still many things urged Caesar on.

14. When these things had been reported to Caesar, he ordered ships to be collected.

15. When the Veneti learn of Caesar's arrival, they will send ambassadors to him.

16. Since they have held our ambassadors, we cannot make peace with them.

17. Although all these things have happened, yet they will fight with us.

18. Since the height of their ships is so great, we shall not be able to harm them.

19. When Caesar set out, we were preparing to winter in that district. 
20. When we are in Gaul, we always remain in that city several days.

21. When Caesar was setting out for Illyricum, he was informed of this war.

22. Since we now have sufficient ships, we shall attack the towns of the Veneti.

23. Since the Veneti have lost so many men, they will surrender immediately and send back our ambassadors.

24. Although the Veneti have fought with great courage, they will be deprived of their arms.

509. EXERCISE FOR ORAL TRANSLATION

1. When Caesar is in Gaul. Give in the present, imperfect, and future.

2. Since the enemy have many ships.

3. Although they are fighting bravely.

Give in all tenses except the future and future perfect.

4. After ${ }^{1}$ the war is finished, we shall return home.

5. Notwithstanding the fact that I was already in the city.

6. Inasmuch as we have been defeated, we surrender.

7. Caesar sent men to attack the town. Give in five ways.

8. I have a sword. Use the dative of the possessor and conjugate in the present indicative.

9. For the purpose of returning. For the purpose of drawing up a line of battle. To seek peace they came.

10. A place suitable for a camp. A place next to the river. A man desirous of peace. 


\section{LESSON XXIV}

\section{PARTICIPLES}

510. References:

1. Formation and Use of Participles : 359-361.

2. Tenses of Participles : 360-365.

3. Participles used for Clauses : 375, 1-6.

\section{Explanations:}

1. Do not confuse the participle which is used purely as an adjective by itself and the forms in -ing and -ed which are parts of the compound verb in English.

Participle

Flowing water.

A wounded soldier.

Compound Verb

The water is-flowing.

The soldier has-been-wounded.

2. As regards the tense of the participle, much more exactness must be observed in Latin than in English. In English we frequently employ the present participle where the perfect is necessary in Latin. This is particularly true of deponent verbs, e.g.,

Addressing his soldiers, Caesar began battle.

Caesar suōs cohortätus proelium commisit.

Here "addressing," a present participle in English, really represents an action which took place before he began battle and therefore means "having addressed." Hence the perfect participle must be employed in Latin.

\section{EXERCISE FOR WRITTEN TRANSLATION}

1. Led on by these things, the Venelli hastened to the camp of Sabinus.

2. There the Romans, drawn up in line of battle, were awaiting their attack. 


\section{PART I - EXERCISES}

3. Sabinus, addressing his men, gave the signal for battle.

4. The soldiers, being eager for battle, had been awaiting the signal.

5. Then they made an attack upon the Venelli (who were) ${ }^{1}$ coming (up).

6. The enemy, hampered by the things which they were carrying, were easily repulsed.

7. Our men pursued those (who were) ${ }^{1}$ withdrawing from the contest.

8. Overtaking them exhausted with wounds, they killed a large number of them.

9. Crassus (who had been) ${ }^{1}$ sent by Caesar led his army into the territory of the Sotiates.

10. There he easily conquered all who dared ${ }^{2}$ to meet him.

11. He attacked a town of the Sotiates (which was) ${ }^{1}$ exceptionally (well) fortified by nature.

12. Adiatunnus, a leader of the Sotiates, attempted ${ }^{2}$ to make a sally, (but) was driven back into the town.

13. (Although) he (was) ${ }^{1}$ defeated and driven back into the town, he was not killed.

14. When the town had been captured, the barbarians alarmed by this sent for aid.

15. Crassus being informed of this, decided to fight on the following day.

16. On that day the troops (were) drawn up in line of battle (and) ${ }^{1}$ awaited the enemy.

1 Omit the words in parenthesis and use a participle.

${ }^{2}$ Use a participle. 
17. But the enemy, fearing the Roman soldiers, remained in camp.

18. Then Crassus led his soldiers (who were) ${ }^{1}$ eager to fight to the camp of the enemy.

19. But the soldiers of the enemy (who had been) ${ }^{1}$ stationed on the fortifications defended the camp bravely.

20. But one part of the city (which had) ${ }^{1}$ not (been) fortified with the same care was captured by the Romans.

21. Then the shouts of. our men, heard by the enemy, frightened them and they betook themselves to flight.

22. Our cavalry pursued them as they fled. ${ }^{2}$

23. Overtaking them, they killed a large number of those (who were) ${ }^{1}$ fleeing.

24. The rest of the Aquitanians, being informed of this battle, voluntanily surrendered to Crassus.

\section{EXERCISE FOR ORAL TRANSLATION}

1. A wounded soldier. Decline this phrase.

2. A fleeing soldier. Decline this phrase.

3. These men were killed (while) setting out from the city.

4. Setting out from the city, they marched into Gaul.

5. Of those (who had been) captured, a few escaped.

6. (Although) I (have been) defeated, I will not surrender.

7. (If he is) captured, he will be killed.

8. (Since) they had been defeated, they sought peace.

9. Fearing treachery, Caesar kept his soldiers in camp.

10. He was wounded while he was fighting.

${ }^{1}$ Omit the words in parenthesis and use a participle.

${ }^{2}$ Use a participle. 


\section{LESSON XXV}

\section{ABLATIVE ABSOLUTE}

\section{REFERENCES :}

1. Review Participles : 359-364, 375, 511.

2. The Ablative Absolute : $369,372,373$.

3. Ablative Absolute without a Participle : 370.

4. Ablative Absolute for Clauses : 371.

\section{EXPLANATION :}

Learn by heart the following phrases :

Hīs rēbus cögnitīs, after this was found out (these things having been found out).

Hīs rēbus gestis, when this had been done (these things having been done). Hōc bellō cōnfectō, when this war had been finished (this war having been finished).

Hōc proeliō cōnfectō, when this battle had been fought (this battle having been finished).

Mē invītō, against my will, without my consent (I being unwilling). Caesare cōnsule, in the consulship of Caesar (Caesar being consul). Caesare duce, under the leadership of Caesar (Caesar being leader). Dis immortālibus ducibus, under the guidance of the immortal gods (the imimortal gods being leaders).

\section{EXERCIISE FOR WRITTEN TRANSLATION}

1. In the consulship of Crassus and Pompey the Usipetes, a tribe of Germans, had come to the Rhine.

2. 'The Menapii who inhabited this region, abandoning their towns, crossed the Rhine to their kinsmen.

3. By placing many garrisons, they made ${ }^{1}$ it impossible for the' Usipetes to cross the Rhine.

4. At last the Usipetes, abandoning the hope of crossing, departed from the river.

5. When the Menapii heard this, they crossed the Rhine to their former homes.

1 " made it impossible for" = "made it so that the Menapii could not." 
6. The Usipetes, however, after marching for three days, returned in one night.

7. Then, making a sudden attack, they crushed the Menapii, seized their boats, and crossed the Rhine into Gaul.

8. Many thousands of Germans had crossed the Rhine several years before against Caesar's will.

9. Caesar had destroyed a large part of these and driven the rest across the Rhine into Germany.

10. Upon hearing of the arrival of the Usipetes, Caesar returned to the army earlier than he was accustomed.

11. After he had brought together a grain supply and chosen his cavalry, he started toward the Germans.

12. 'The Germans, learning of Caesar's arrival, sent an embassy to confer with him.

13. These ambassadors spoke with Caesar in the presence $^{1}$ of many soldiers.

14. They begged that, after hearing their reasons for ${ }^{2}$ coming, he would allow them to remain in Gaul.

15. Caesar, with all the ambassadors listening, said that no fields were vacant in Gaul.

16. For he knew that, if ${ }^{3}$ fields were granted to one tribe, other tribes of Germans would cross the Rhine.

17. He therefore ordered the leaders of the Germans to collect their forces and return to Germany.

18. Since our cavalry has been sent away, we shall not begin battle. 
19. Although our camp had been placed in an unfavorable position, they did not dare to make an attack on us.

20. If this battle is announced across the Rhine, the rest of the Germans will not dare to cross.

21. Since the work of fortifying was finished, our (soldiers) did not fear an attack.

22. Labienus drew up his line of battle and awaited the arrival of the enemy.

23. This one legion was easily conquered because the camp was pitched in an unfavorable position.

24. Although many desired to fight, Caesar was unwilling to begin battle.

\section{EXERCISE FOR ORAL TRANSLATION}

1. In the consulship of Crassus and Pompey.

2. In our consulship. In your consulship. In my consulship.

3. Under his leadership. Under my leadership.

4. He spoke, many being present. He spoke in the presence of many. He spoke in the presence of a few. He spoke in my presence. He spoke in your presence.

5. Having finished his work, he went home. He finished his work and went home.

6. Saying this, he departed. When he had said this, he departed. He said this and departed.

7. Though he had finished his work, he remained. Since he had finished his work, he went home.

8. He was unwilling to speak while many were listening.

9. Since so great a number desired (it), he spoke.

10. Though the rest were fleeing, he remained. 


\section{LESSON XXVI \\ THE PASSIVE PERIPHRASTIC}

518. REFERENCES:

1. Formation of the Passive Periphrastic: 383.

2. Dative of Agent : 384 .

3. Uses of the Passive Periphrastic : 385-386.

519. Explanations:

1. The gerundive or verbal adjective may be translated as follows:

Homō laudandus, a man to-be-praised.

Homō timendus, a man to-be-feared.

When this gerundive is combined with the verb sum, we get the passive periphrastic conjugation, which is variously translated.

Hīc homō laudandus est, this man is to-be-praised, must be praised, ought to be praised.

Hīc homō timendus erat, this man was to-be-feared, had to be feared, ought to have been feared.

Haec urbs dēfendenda est, this city is to-be-defended, must be defended, ought to be defended.

2. Deponent verbs take on a passive meaning in the gerundive form and in the passive periphrastic conjugation.

Exercitus hostium sequendus est, the army of the enemy must be followed.

520. EXERCISE FOR WRITTEN TRANSLATION

1. Caesar said to the ambassadors of the Usipetes, "Your tribe must not remain in Gaul."

2. I ought not to grant, especially to so great a multitude, the privilege of settling in Gaul.

3. Therefore you must return to the lands whence you have come. 
4. The ambassadors themselves made no promises, ${ }^{1}$ sut said that they had to report Caesar's orders to their (countrymen).

5. Meanwhile you, Caesar, ought not to come (any) nearer with your army.

6. You ought to remain here; in this place you ought to await our answer.

7. Caesar decided that not even this (request) ought to be granted.

8. If I delay ${ }^{2}$ here, I shall afterward have to contend with an enemy (that is) better ${ }^{3}$ prepared.

9. For these Germans will not think that they must return to Germany at my command.

10. Caesar therefore decided that he ought to fightit-out with the Germans as soon as possible.

11. All the hostages which you have received from our allies must be returned at once.

12. All who go forth from their territories will have to undergo many hardships.

13. We must urge our soldiers not to fear the enemy.

14. We must not longer delay, for we cannot conquer by delaying.

15. The enemy must be given no time for adopting plans.

16. We ought not to lay waste the fields of these men, for they are friends of the Romans.

17. Since we have no boats, we must try to cross by fords.

1 " made no promises" = "promised nothing." 3 " more prepared." 2 Cf. 212. 
18. Our soldiers must seize the heights which the enemy now hold.

19. At ${ }^{1}$ the beginning of a battle a general ought to encourage his soldiers.

20. You ought not to abandon an excellently fortified camp.

21. We must destroy all hope of returning home if we wish our soldiers to remain.

22. The town's fortifications must be strengthened, for the enemy is not far away.

23. The soldiers must not go far from camp, for about a thousand horsenien are at hand.

24. We must not hesitate to lead our troops across this river.

\section{EXERCISE FOR ORAL TRANSLATION}

1. His commands must be executed at once.

2. You must not lay waste these fields. Give in each person and number of this tense.

3. Caesar often had to fight with the Germans.

4. One nation has been defeated, soon another will have to be defeated.

5. Our soldiers must abandon this camp.

6. They must not remain (any) longer in this place. Give sentence 6 in each person and number.

7. Caesar said that all hostages must be returned.

8. I think that our men ought to seize the heights.

9. I think that we ought to start at once.

10. The centurions ought to encourage their soldiers. 


\section{LESSON XXVII}

\section{COMPLEX SENTENCES IN INDIRECT DISCOURSE}

522. REFERENCES:

1. Review $333,337-340,467$.

2. Complex Sentences in Indirect Discourse : $346-348$.

3. Review Sequence of Tenses : 242-246, 248, 250.

\section{EXERCISE FOR WRITTEN TRANSLATION}

1 a. During almost all the wars which had arisen in Gaul help was sent by the Britons.

b. Caesar knows that during almost all the wars which had arisen in Gaul help was sent by the Britons.

c. Caesar knows that during almost all the wars which had arisen in Gaul help had been sent by the Britons.

2 a. He decides to lead the army which he has into Britain.

b. We hear that he decides to lead the army which he has into Britain.

c. We heard that he decided to lead the army which he had into Britain.

3 a. I shall send a man whom I trust to explore the island.

b. Caesar says that he will send a man whom he trusts to explore the island.

c. Caesar said that he would send a man whom he trusted to explore the island.

4. At that time ambassadors of the Morini came to Caesar and promised that they would do what he demanded.

5. Caesar says that he did not wish to leave behind his back enemies who were so powerful. 
6. Therefore he told them that he would receive in 1 surrender those who had sent the embassy.

7. Caesar writes that he set out from Gaul with the ships which he had gathered from all sides.

8. When he was approaching Britain, he saw that all the hills which were near the shore were covered with armed men.

9. For the Britons had learned that Caesar would come to Britain when he had conquered Gaul.

10. Therefore Caesar says that he will wait at anchor for the ships which are coming from the other harbor.

11. But he did not know that the ships which he was waiting for had been held (back) by the wind.

12. We know that both the war galleys and the transports were held (back) by the wind and tide.

13. Caesar said that when these ships came he would proceed about seven miles from that place.

14. But he writes that when the Romans tried to disembark, the Britons made an attack.

15. He noticed that his (men) who were disembarking with difficulty in the waves were hard pressed by the enemy.

16. He tells us that the man who was carrying the standard of the tenth legion encouraged the soldiers thus.

17. "We are fighting," he said, "with fierce barbarians who are unskilled in war."

18. Caesar writes that the soldiers who heard these words began to fight with greater zeal. 
19. But he says that since the soldiers were not able to get a firm footing, they were thrown into confusion.

20. Nevertheless the Britons were finally defeated, and Caesar says that they sent ambassadors to beg for peace.

21. They said that they would send hostages to him if. he desired.

22. Besides they promised that they would do what he ordered.

23. Caesar said that he would receive them in surrender when they sent the hostages.

24. The ambassadors replied that they would report to the Britons what he had said.

\section{EXERCISE FOR ORAL TRANSLATION}

1. I will do what you wish.

2. He has sent men to find this out.

3. They were leading the troops which they had.

4. You had asked what we were doing.

5. I am doing what you have ordered.

Put each one of these sentences in indirect discourse after each tense of dīcō.

6. I do not believe that the soldiers which you have will disembark.

7. He said that the soldiers which he had with him had been armed.

8. "These war galleys," they say, "will be captured."

9. They say that these war galleys will be captured.

10. Who knows why the soldiers cannot gain a firm foothold? 


\section{LESSON XXVIII}

\section{ABLATIVE WITH $\bar{U}$ TOR, ETC. -REVIEW OF THE ABLATIVE CASE}

525. REFERENCES:

1. Ablative with Ütor, etc. : 165 .

2. Review 127-131, 133-136, 138-144, 146-153, 157-161, 167-168.

\section{EXERCISE FOR WRITTEN TRANSLATION}

1. When they had enjoyed peace for a few days, the ships in which the horsemen were being transported arrived.

2. But when these were approaching the shore, they were driven back by a storm.

3. On that night many of the ships were filled with water, so that Caesar could not use them.

4. Learning of this, the Britons thought that our men had been cut off from their supplies.

5. For the food which the Romans lived on was beginning to fail them.

6. The Britons even hoped that they would get possession of Caesar's camp and baggage.

7. But Caesar's soldiers repaired the ships with so great zeal that in a short time they were fit for sailing.

8. Meanwhile one of the legions had gone a little too far from the camp and was surrounded by the enemy.

9. The soldiers of this legion were so crowded (together) that they were unable to use their swords. í 10. (Though) alarmed by this circumstance, ${ }^{1}$ the sol- 
diers were performing their duty with the greatest bravery.

11. On Caesar's arrival the enemy halted and our troops began to recover from fear.

12. At length using their swords and javelins, they put the enemy to flight. ${ }^{1}$

13. Storms followed for several days, so that the Romans were kept from battle.

14. Meantime the Britons sent messengers in all directions and summoned aid.

15. Then, collecting a large multitude of cavalry and infantry, they came to gain possession of the camp of the Romans.

16. But our men easily defeated them and drove them some in one direction, others in another.

17. On the next day ambassadors sent by the enemy came to Caesar to beg peace.

18. Although they had employed treachery against him, Caesar received them in surrender.

19. Then securing suitable weather, he set sail a little after midnight.

20. All of the ships came safe to the shore of Gaul.

21. But the Morini, led on by the hope of plunder, surrounded the soldiers of two boats.

22. The Romans fought with the greatest valor for more than four hours.

23. This fight was reported to Caesar, and he immediately sent the cavalry to aid his (men).

${ }^{1}$ in fugam dō, put . . . to flight. 
24. On the arrival of the horsemen the enemy were terrified and fled.

\section{EXERCISE FOR ORAL TRANSLATION}

1. We have gained possession of the camp; of the baggage; of the town; of the village; of the city.

2. We cannot use our ships; our swords; our javelins; our shields.

3. They enjoy life; liberty; friendship; peace.

4. He has performed his duty; the task.

5. They fight with javelins; with the enemy; with great courage; with us.

6. He has done this in accordance with the laws.

7. This road is many miles longer than the other.

8. They surpass us in courage. They remain in the city in the summer.

9. The army will set out from the city; from Rome; from the city of Rome.

10. On the eighth day. Within eight days. For eight days. 


\section{SPECIAL VOCABULARIES}

\section{PART I}

\section{LESSON I}

altus, -a, -um, deep, high.

angustus, -a, -um, narrow.

coniūrātiō, -ōnis, f., conspiracy; coniūrātiōnem faciō, form a conspiracy.

contendō, -ere, contendī, contentum, hasten; struggle, contend, fight.

contineō, -ēre, continuī, contentum, hold in, shut in, hem in, bound.

contrā, prep. with acc. case, against.

cōpiae, -ārum, f. pl., troops, forces.

dīvidō, -ere, dīvīsī, dīvīsum, separate, divide.

exspectō, -āre, -āvī, -ātum, await, wait for. With acc. case.

facilis, -e, easy; facile, adv., easily.

fīnis, -is, m., end, limit, boundary; fīnēs, -ium, m. pl., territory, country, land.

flümen, flūminis, n., river.

gerō, -ere, gessī, gestum, carry on,

wage; bellum gerō, wage war.

iam, adv., now, already.

importō, -āre, -āvī, -ātum, bring in, import. incolō, -ere, incoluī, -, inhabit, live in, dwell. With acc. case.

maneō, -ēre, mānsī, mānsūrus, remain, stay.

mercātor, -ōris, m., merchant. nam, conj., for.

prōvincia, -ae, f., province.

saepe, adv.; often.

vincō, -ere; vīcī, victum, conquer, defeat.

\section{LESSON "II}

alius, alia, aliud, another, other; alius ... alius, one . . another. Cf. 56.

alter, altera, alterum, the other (of two); alter... alter, the one . . . the other. Cf. 56.

appellō, -āre, -āvī, -ātum, call, call by name, name.

vocō, -āre, -āvī, -ātum, call, summon.

certus, -a, -um, certain, sure, fixed; certiōrem faciō (make more certain), inform. Cf. 6768. certior fīo (be made more certain), be informed.

convocō, -āre, -āvī, -ātum, call together, summon.

dēligō, -ere, dēlēgī; dēlēctum, choose, appoint. Cf. 67-68. 
exercitus, -ūs, m., army.

fīnitimus, -a, -um, neighboring; fïnitimus, -ī, m., neighbor.

fīō, fierī, factus sum (pass. of faciō), be 'made, be done, become. Cf. 58.

habeō, -ēre, habuī, habitum, have, hold, consider. Cf. 67-68. imperātor, -ōris, m., general, commander.

itaque, therefore, and so. iter, itineris, n., road, way, route, march.

magistrātus, -ūs, m., magistrate, officer; magistracy, office.

nōbilis, -e, noble, of high birth.

occupō, -āre, -āvī, -ātum, seize, capture.

potēns, potentis, powerful.

putō, -āre, -āvī, -ātum, think, consider. Cf. 67-68.

quod, conj., because.

rēgnum, -ī, n., royal power, kingdom.

videor, vidērī, vīsus sum, seem. Cf. 58 .

\section{LESSON III}

addūcō, -ere, addūxī, adductum, lead on, influence.

auctōritās, -tātis, f., prestige, influence.

cōnsilium, -ī, n., plan; cōnsilium

capiō, adopt a plan.

differō, differre, distulī, dīlātum, differ.

exeō, exīre, exī̄, exitum, go out, go forth.

fugiō, fugere, fūgī, fugitum, flee. gladius, $-\overline{\mathrm{i}}$, m., sword.

ingēns, ingentis, great, huge. lātitūdō, -dinis, f., width, breadth. lēx, lēgis, f., law.

lingua, -ae, f., tongue, language. multitūdō, -dinis, f., multitude, great number, number.

oppūgnō, -āre, -āvī, -ātum, attack, assail.

ōrātiō, -ōnis, f., speech; ơrātiōnem habeō, deliver a speech.

pāx, pācis, f., peace.

pīlum, -ī, n., javelin.

proficīscor, proficīscī, profectus sum, set out, start.

superō, -āre, -āvī, -ātum, overcome, excel, conquer, surpass. virtūs, -tūtis, f., valor, courage, bravery.

\section{LESSON IV}

centuriō, -ōnis, m., centurion.

collis, -is, m., hill.

coniciō, conicere, coniēcĩ, coniectum, throw, hurl.

conveniō, convenīre, convēnī, conventum, come together, assemble, gather.

ēgredior, ēgredī, ēgressus sum, go out, go forth, come out, come forth.

indūcō, indūcere, indūxī, inductum, lead on, influence.

interficiō, interficere, interfēcī, interfectum, kill.

legiō, -ōnis, f., legion.

litterae, -ārum, f. pl., letter, dispatch.

mürus, -ī, m., wall. nūntiō, -āre, -āvī, -ātum, report, announce.

nūntius, -ī, m., message, messenger. 
pellō, pellere, pepulī, pulsum, drive, rout.

pōnō, pōnere, posuī, positum, place; castra pōnō, pitch camp, encamp.

castra moveō (movēre, mōvī, mōtum), move camp, break camp.

redūcō, redūcere, redūxī, reductum, lead back.

ripa, -ae, f., bank (of a river).

scūtum, -ī, n., shield.

silva, -ae, f., wood, forest.

statim, adv., immediately, straight-

way, at once.

tribūnus, $-\overline{1}, \mathrm{~m} .$, tribune.

\section{LESSON V}

$\bar{a}, a b$, prep. with abl. case, from, away from, from the vicinity of. Cf. 198.

ad, prep. with acc. case, to, near, to the vicinity of. Cf. 198. collocō, -āre, -āvī, -ātum, place, station.

domus, -ūs, f., house, home. Cf. 194.

èdūcō, ēdūcere, ēdūxī, ēductum, lead out, lead forth.

ferē, adv., almost. Usually placed after the word modified. Cf. 411.

fortūna, -ae, f., fortune, lot.

hīberna, -ōrum, n. pl., winter quarters.

incendō, incendere, incendi, incēnsum, burn, set fire to.

lēgātiō, -ōnis, f., embassy.

māgnum iter, māgnī itineris, n., forced march.

perterreō, perterrēre, perterruī, perterritum, frighten (thoroughly).

praesidium, $-\overline{1}, \mathrm{n} .$, garrison, guard, protection.

redeō, redīre, redīi, reditum, go back, return.

revertor, revertī, reversus sum or revertī, reversum, go back, come back, return.

rūs, rūris, n., country (as opposed to the city). Cf. 194.

temptō, -āre, -āvī, -ātum, try, attempt.

terrā marique, on land and sea. Cf. 189.

tōtus, -a, -um, whole, entire, all. vīcus, $-\overline{1}, \mathrm{~m}$. , village.

\section{LESSON VI}

altitūdō, -dinis, f., height, depth. animus, -ī, m., mind, opinion, disposition; bonō animō, well disposed; inimīcō animō, ill disposed, hostile; . . toward, in with the acc. case.

caput, capitis, n., head.

diligentia, -ae, f., diligence, care. fidēs, fideī, f., faith, reliability, honor.

frūmentum, -ī, n., grain.

grātia, -ae, f., favor, influence, popularity.

imperium, -ì, n., command.

intervāllum, $-\overline{1}, \mathrm{n} .$, distance, interval.

spatium, -ī, n., space, distance.

labor, -ōris, m., toil, effort, labor. māgnitūdō, -dinis, f., size, greatness.

mille, indecl. adj., a thousand; milia, -ium, n. pl., thousands. 
modus, -ì, m., manner, kind; èius modī, of this kind.

mora, -ae, f., delay.

ōrdō, ördinis, m., rank, class. passus, -ūs, m., pace, step; mille passūs, a (Roman) mile; mīlia passuum, (Roman) miles. pès, pedis, m., foot. pondus, ponderis, n., weight. saxum, -i, n., stone, rock.

summus, -a, -um, highest, greatest, utmost.

turris, -is (acc. turrim, abl. turrī), f., tower.

\section{LESSON VII}

cōgnōscō, cōgnōscere, cōgnōvī, cōgnitum, learn, find out; know. Cf. 209-210.

concilium, -ī, n. | meeting, counconventus, $-\overline{\mathrm{u}} \mathrm{s}, \mathrm{m}$. $\}$ cil, assembly. cōnor, -ārī, -ātus sum, try, attempt. cūr, why?

doceō, docēre, docuī, doctum, teach, explain. Cf. 72 .

expūgnō, -āre, -āvī, -ātum, storm, take by storm, capture.

intellegō, intellegere, intellēxī, intellēctum, m., understand, know.

iter faciō, make a march, march. neglegō, neglegere, neglēxī, neglēctum, disregard, neglect, overlook.

nēmō (gen. nūllīus, dat. nēminī, acc. nēminem, abl. nūllō), no one.

officium, -ī, n., duty. perīculum, $-\overline{\mathrm{i}}, \mathrm{n}$. , danger.

quaerō, quaerere, quaesīvī, quaesītum, ask, inquire. Cf. 72 . quam, adv., how. Modifies adjectives and adverbs especially. quantus, -a, -um, how great? how much? how large?

quisque, quaeque, quidque, each, each one.

quō, whither, to what place. With verbs of motion, where.

ubi, where, in what place.

quot, indecl. numeral, how many? reperiō, reperīre, repperī, repertum, find out, discover.

retineō, retinēre, retinūi, retentum, hold back, keep'back.

\section{LESSON VIII}

adventus, -ūs, m., coming, arrival, approach.

aestās, -tātis, f., summer.

complūrès, -ia (-a), several, many. eō, adv., there, to that place. With verbs of motion.

explōrātor, "ōris, m., scout.

höra, -ae, f., hour.

ibi, adv., there, in that place. With verbs of rest.

lūx, lūcis, f., light; prīmā lūce, 'at daybreak.

memoria, -ae, f., memory.

mēnsis, -is, m., month.

nātiō, -ōnis, f., race, tribe, nation, people.

nox, noctis, f., night.

occāsus, -ūs, m., setting.

perveniō, pervenīre, pervēnī, per-

ventum, come through, arrive, reach. With ad and acc. case. posterus, -a, -um, following, next. praemittō, praemittere, praemīsī, praemissum, send ahead, send forward. 
proximus, -a, -um, next, nearest. sōl, sōlis, m., sun; sōlis occāsus, the setting of the sun, sunset. vigilia, -ae, f., watch (a portion of the night. Cf. 175).

\section{LESSON IX}

absum, abesse, āfuĩ, āfutūrus, be away, be distant, be absent. aedificium, -ĩ, n., building. amplius, adv., more. Cf. 159. audāx, audācis, bold, daring. cotīdiē, adv., daily, every day. dēfendō, dēfendere, dēfendī, dē-

fēnsum, defend, protect.

eques, equitis; m., horseman; equitēs, -um, m. pl., horsemen, cavalry.

equitātus, -ūs, m., cavalry. With singular verb.

pedes, peditis, m., foot-soldier; peditēs, -um, m. pl., footsoldiers, infantry. peditätus, -ūs, m., infantry.

singular verb.

factum, -ī, n., deed, act. fossa, -ae, f., trench, foss, ditch. longē, adv., far; comp. longius, farther. Cf. 159.

minus, adv., less̀. Cf. 159. mūnītiō, -ōnis, f., fortification. pateō, patēre, patuī, - be open, extend.

paucī, paucae, pauca, few, a few. paulum, -ī, n., little; paulō, adv., a little.

prōcēdō, prōcēdere, prōcessī, prōcessum, advance, proceed.

proelium, -ī, n., battle; proelium committō (-ere, -mīsī, -miscum), begin battle, join battle. quantō ... tantō, the (more) ... the (more). Cf. 162. relinquō, relinquere, relĩquī, relictum, leave, asandon. spēs, speī, f., hope. timor, -ōris, m., fear. văllum, -ī, n., rampart.

\section{LESSON $X$}

āmittō, amittere, āmīsī, āmissum, lose.

apud, prep. with acc. case, near, at, with, among, around. augeō, augēre, auxĩ, auctum, increase. Transitive verb.

auxilium, -ī, n., help, aid.

cēterī, cēterae, cëtera, the other, the rest of; cēterī, as a noun, the rest. circum, prep. with acc. case, around, about.

committō, committere, commīsī, commissum permittō, permittere, intrust. permīsī, permissum coniungō, coniungere, coniūnxĩ, coniūnctum, join, untie. When the English verb is intransitive the reflexive must be used in Latin.

dēdō, dēdere, dēdidī, dēditum, surrender, give up. When the English verb is intransitive the reflexive must be used in Latin. equester, equestris, equestre, cavalry, of the cavalry.

māgnopere, adv., greatly.

māiōrēs, -um, m. pl., ancestors. Cf. 3 .

mè cōnferō (cōnferre, contulī, collātum), betake myself, go. Reflexive verb. 
polliceor, pollicērī, pollicitus sum, promise.

potestās, -tātis, f., power. recipiō, recipere, recēpī, receptum, take back; mē recipiō, I withdraw. Reflexive verb.

sequor, sequī, secūtus sum, follow, pursue.

timeō, -ēre, -uī, -, fear, be afraid of.

trādō, trādere, trādidī, trāditum, hand over, give over, surrender. vērus, -a, -um, true.

\section{LESSON XI}

amicitia, -ae, f., friendship.

animadvertō, animadvertere, animadvertī, "animadversum, notice; , in aliquem animadvertō, infict punishment on any one, punish.

celeritās, -tātis, f., speed, swiftness.

cohors, cohortis, f., cohort.

commoveō, commovēre, commōvī, commōtum, move, alarm. cōnsuētūdō, -dinis, f., custom, manner.

difficultās, -tātis, f., difficulty. dolor, -ōris, m., sorrow.

impetus, -ūs, m., attack; impetum in aliquem faciō, make an attack on any one.

iniūria, -ae, f., wrong, harm; iniūriā, unjustly, wrongfully. Cf. 132.

iūs, iūris, n., right, justice; iūre, rightly, justly. Cf. 132.

iūssus, -ūs, m., order, command; iūssū, at the order; iniūssũ, without the order. Cf. 139. iuvō, iuvāre, iūvī, (iūtum), aid, help. Cf. 81.

lïber, lỉbera, lỉberum, free.

lỉberō, -āre, -āvī, -ātum, free, set free.

meritum, -ī, n., deserts, service; meritō, adv., deservedly. Cf. 132.

mōs, mōris, m., custom, manner. ōrō, -āre, -āvì, -ātum, beg.

permoveō, permovēre, permōvī,

permōtum, move thoroughly, alarm.

quīdam, quaedam, quiddam (quoddam), certain, a certain. Cf. 51 .

- sponte, of . . accord; meã sponte, of my own accord, etc. studium, -ī, n., zeal, eagerness. voluntãs, -tātis, f., good will, consent.

\section{LESSON XII}

accipiō, accipere accēpī, acceptum, receive.

aciēs, aciēī, f., line (of battle).

arbitror, -ārī, -ātus sum, think, consider.

āvertō, āvertere, āvertī, āversum, turn away, turn aside.

cōnspiciō, cōnspicere, cōnspēxī, cōnspectum, catch sight of, see. dīmittō, dīmittere, dīmīsī, dĩmissum, dismiss, send in different directions, send away.

discēdō, discēdere, discessī, discessum, depart, withdraw.

exīstimō, -āre, -āvī, -ātum, think, consider.

expellō, expellere, expulī, expulsum, drive out, expel. 
incipiō, incipere, incēpī, inceptum, begin.

coepĩ, (coepisse), coeptum, began. Used only in the perf., plup., and fut. per.

insequor, insequī, insecūtus sum, pursue, follow up.

instruō, instruere, īnstrūxī, īnstrūctum, draw up.

multō diē, late in the day.

ostendō, ostendere, ostendī, ostentum, show.

rēs frūmentaria, reĩ frūmentāriae,

f., grain supply, supply of grain.

spērō, -āre, -āvī, -ātum, hope.

sub, prep., with abl., under, at the foot of; with acc., under, to the foot of.

sustineō, sustinērē, sustinuī, sustentum, withstand.

\section{LESSON XIII}

arcessō, arcessere, arcessīini, arcessitum, invite, summon, send for.

brevis, -e, short; brevī tempore, soon, in a short time.

circumsistō, circumsistere, circumstetī, - , stand around, surround. Cf. 62.

circumveniō, circumvenīre, circumvēnī, circumventum, come around, surround. Cf. 62.

cōnsīdō, cōnsīdere, cōnsēdī, cōnsessum, settle.

manus, -ūs, f., hand, band, force. moneō, monēre, monuī, monitum, warn, advise, give a warning. Cf. 65.

novus, -a, -um, new. obtineō, obtinēre, obtinuĩ, obtentum, hold, have possession of. paene, adv., almost, nearly. prīmō, adv., at first.

quaerō, quaerere, quaesīvī, quaesītum, inquire, make inquiry, seek, ask. Cf. 72.

respondeō, respondēre, respondi, respōnsum, reply, make a reply, answer.

sentiō, sentīre, sēnsī, sēnsum, feel, perceive, hold an opinion. tandem, adv., at length, finally.

trādūcō, trādūcere, trādūxī, trāductum, lead across. Cf. 6263.

trānseō, trānsīre, trānsiī, trānsitum, cross, go across, go over. valeō, valēre, valuī, valitūrus, be strong, be powerful. Learn the idiomatic uses of valeō and possum given in 66 .

\section{LESSON XIV}

accidō, accidere, accidī, -, befall, happen.

adiuvō, adiuvāre, adiūvī, (adiūtum), help, aid. With acc. Cf. 81.

adsum, adesse, adfuī, adfutūrus, be near, be present, aid, help. With dat. Cf. 83.

bellum inferō (înferre, intulī, illātum), make war on. With dat. of the person.

calamitās, -tātis, f., disaster, calamity, loss.

cōnfīdō, cōnfīdere, cōnfīsus sum, trust. Cf. 80.

convocō, -āre, -āvī, -ātum, call together, summon. 
crēdō, -re, crēdidī, crēditum, believe.

imperō, -āre, -āvī, -ātum, command, order, rule. Cf. 80.

loquor, loquī, locūtus sum, speak, say.

māximē, adv., most, especially. noceō, nocēre, nocuī, nocitum. harm, do harm to, injure. Cf. 80. occurrō, occurrere, occurrī, occursum, meet.

opprimō, opprimere, oppressī, oppressum, crush, overwhelm. With acc.

pāreō, pārēre, pāruī, 一, obey. Cf. 80.

persuādeō, persuādēre, persuāsī, persuāsum, persuade. $\quad$ Cf. 80. praecipiō, praecipere, praecēpī, praeceptum, instruct. Cf. 83. praeficiō, praeficere, praefēcī, praefectum, put in charge, put in command. Cf. 83-84.

praesum, praeesse, praefuī, praefutūrus, be in command, be in charge. Cf. 83.

prōvideō, prōvidēre, prōvīdī, prōvisum, look out for, provide for, see to it.

resistō, resistere, restitī, resist, oppose. Cf. 80 . sine, prep. with abl. case, without. studeō, studēre, studuĩ, -, desire. Cf. 80.

\section{LESSON XV}

ācriter, adv., fiercely, sharply. adorior, adorīīi, adortus sum, attack. With acc.

agō, agere, ēgī, āctum, do, treat, discuss, speak. at, conj., but.

captivus, $-\overline{\mathrm{i}}, \mathrm{m}$., captive.

celeriter, adv., quickly, swiftly. colloquium, $-\overline{1}, \mathrm{n} .$, conference.

colloquor, colloquī, collocūtus sum, speak with, confer with. commeătus, -ūs, m., supplies. Commonly used in the singular. cōnsequor, cōnsequī, cōnsecūtus sum, overtake.

ferō, ferre, tulī, lātum perferō, perferre, pertulī,
perlātum

hiemō, -āre, -āvī, -ātum, winter, spend the winter.

interclūdō, interclūdere, interclūsī, interclūsum, shut in, cut off.

iterum, adv., again, a second time.

moror, -ārī, -ātus sum, delay, linger.

postulō, -āre, -āvī, -ātum, demand. Cf. 72, 262.

praemittō, praemittere, praemīsī, praemissum, send ahead, send forward.

prohibeō, prohibēre, prohibuī, prohibitum, keep away, keep out, cut off, prevent.

regiō, -ōnis, f., district, region. tam, adv., so.

\section{LESSON XVI}

āgmen, āgminis, n. column, army (on the march); novissimum ägmen, rear of the army.

cōnstituō, cōnstituere, cōnstituī, cōnstitūtum, set, appoint.

cornū, -ūs, n., horn, wing; à dextrō (sinistrō) cornū, on the right (left) wing. 
dexter, dextra, dextrum, right, on the right (hand).

fuga,-ae, f., flight, escape.

impedimentum, -ī, n., hindrance; impedimenta, -ōrum, n. pl., baggage.

iniūria, -ae, f., wrong, harm.

pōns, pontis, m., bridge.

postrīdiē ēius diēī, on the day after

this, on the following day.

praemium, -i, n., reward.

premō, premere, pressī, pressum,

press, press hard, overwhelm.

salūs, -ūtis, f., safety, welfare.

sīgnum, -ì, n., signal, standard.

sinister, sinistra, sinistrum, left, on the left (hand).

subsidium, -i, n., reënforcement, aid. ūsus, -ūs, m., use, advantage. Cf. 90. uterque, utraque, utrumque, each, both.

victöria, -ae, f., victory.

\section{LESSON XVII}

accēdit, accēdere, accessit, added to this is the fact, there is the additional fact. Cf. 264.

accidit, accidere, accidit, it happens. Cf. 264.

certus, -a, -um, certain, fixed. cohortor, -ārī, -ātus sum) hortor, ārī, -ātus sum $\}$ urge. diū (adv.), long, for a long while; comp., diūtius; superl., diūtissimē.

èvenit, ēvenīre, ēvēnit, the result is, the outcome is. Cf. 264 . faciō, facere, fēcī, factum efficiō, efficere, effēcī, about. effectum $\left\{\begin{array}{l}\text { make, } \\ \text { bring it } \\ \text { about. } \\ \text { Cf. } 264 .\end{array}\right.$ fit, fierī, factum est, it happens, the result is. Cf. 264. $\left.\begin{array}{l}\text { intereā } \\ \text { interim }\end{array}\right\} \mathrm{adv} .$, meanwhile.

latus, lateris, n., side, flank; ab utrōque latere, from (on) both sides; à lateribus, on-the sides, on the flanks.

mūniō, mūnīre, mūnīvi, mūnītum, fortify.

negōtium, -ī, n., affair, task, business; negōtium dō, give the task to, employ. Cf. 262. nūllus, -a, -um, no.

ördō, ōrdinis, m., order, rank, class.

cōnscrībō, cōnscrībere, cōnscrīpsī, cōnscrīptum, enroll, levy.

servitūs, -ūtis, f., slavery.

singuli, -ae, -a, one by one, singly. subsequor, subsequī, subsecūtus sum, pursue, follow closely.

tergum, -ī, n., back, rear; à tergō, from the rear, on the rear. ulterior, ulterius, farther.

vāstō, -āre, -āvī, -ātum, lay waste, devastate.

\section{LESSON XVIII}

audeō, audēre, ausus sum, dare. Cf. 329.

barbarus, -a, -um, barbarous; barbarus, -ī, m., barbarian.

citerior, citerius, hither, nearer. cōgō, cōgere, coēgī, coāctum, collect, gather; force, compel. Cf. 329,332 .

coniūrō, -āre, -āvī, -ātum, conspire, band together.

dēbeō, dēbēre, dēbuī, dēbitum, ought, owe. Cf. 329. 
dubitō, -āre, -āvī, -ātum, hesitate; doubt. Cf. 329.

fīnem faciō, make an end, finish, put an end to. With gen.

iubeō, iubēre, iūssī, iūssum, order, command, bid. Cf. 332.

licet, licēre, licuit, it is permitted, may. Cf. $325,3$.

maleficium, -ī, n., wrongdoing, harm.

mālō, mālle, mālūi, -, prefer.

Cf. 329,332 .

mātūrō, -āre, -āvī, -ātum, hasten .

Cf. 329.

nihil, indecl. noun, n., nothing . nōlō, nōlle, nōluī, -, be unwilling.

numerus, -ī, m., number. obses, obsidis, m., hostage. oportet, oportēre, oportuit, it is fitting, ought. Cf. 325, 2. patior, patī, passus sum, allow,

permit. Cf. $329,332$. placet, placēre, placuit, it pleases,

it is pleasing; decide. Cf. 325, 1. posteā, adv., afterward.

ratiō, -ōnis, f., scheme, manner, way, means, method. rūmor, -ōris, m., report, rumor.

\section{LESSON XIX}

Learn the uses of alius, alter, etc., in 56 .

āgmen, āgminis, n., column, line (of march).

cōnservō, -āre, -āvī, -ātum, preserve, save.

cōnsilium capiō (capere, adopt a cēpi, captum) cōnsilium ineō (inīre, inī̄, initum) convertō, convertere, convertī, conversum, turn, change.

dēmōnstrō, -āre, -āvī, -ātum, show.

èripiō, ēripere, ēripuī, ēreptum, snatch away, rescue, save; mē èripiō, escape.

longē (adv.), far, by far.

medius, -a, -um, middle, midale of. Cf. 108.

primus, -a, -um, first, first part of. Cf. 108.

quantus, -a, -um, how much? quantum, -ī, n., how much? Cf. 105.

reliquus, remaining, rest of. Cf. 108.

satis, indecl. noun, n., enough, sufficient. Cf. 105.

satis, adv., sufficiently, enough.

summus, -a, -um, highest, most, greatest, utmost; top of. Cf. 108.

tantus, -a, -um, so great, so much; tantum, -ī, n., so much. Cf. 105.

ūnā (adv.), along, together.

\section{LESSON $X X$}

adversus, -a, -um, opposite. Cf. 92.

amicus, -a, -um, friendly; amīcus, $-\bar{i}, \mathrm{~m} .$, friend. Cf. $92,95$.

autem (adv.), postpositive, however, nevertheless.

circiter, adv., used especially with numerals, about.

contrārius, -a, -um, facing, opposite. Cf. 92.

cupidus, -a, -um, eager for, desirous. Cf. 114. 
lissimilis, -e, unlike. Cf. 92. initimus, -a, -um, neighboring; fïnitimus, $-\overline{\mathbf{1}}, \mathrm{n} .$, neighbor. Cf. $92,95$.

idōneus, -a, -um, suitable, fit.

Cf. 92.

imperītus, -a, -um, unskilled, igno-

rant, unacquainted. Cf. 114.

inimicus, -a, -um, unfriendly, hostile; inimicus, $-\mathbf{i}, \mathrm{m}$. (personal) enemy. Cf. 92.

occīdō, occīdere, occīdī, occīsum,

kill, cut down, slay.

pār, paris, equal.

perītus, -a, -um, skilled, skillful, acquainted. Cf. 114.

plēnus, -a, -um, full. Cf. 114. profectiō, -ōnis, f., departure, setting out.

militāris, -e, military, of the sol-

diers; rēs mīlitāris, military affairs, war. similis, -e, like, similar. Cf. 92.

\section{LESSON XXI}

attingō, attingere, attigī, attactum, touch.

causā, for the purpose of. Used with the gen. case which always precedes.

concēdō, concēdere, concessī, concessum, grant, yield, allow. Cf. 262.

conclāmō, -āre, -āvī, -ātum, cry out, shout.

condiciō, -ōnis, f., terms, condition, lot.

cōnficiō, -ficere, -fēcī, -fectum, finish, accomplish.

cōnsanguineus, -a, -um, of the same blood, kindred; cōnsan- guineus, -ī, m., kinsman, relative.

cōnstituō, cōnstituere, cōnstituī, cōnstitūtum, decide; construct; set, appoint, establish.

dē (prep. with abl. case), about, regarding.

dēditiō, -ōnis, f., surrender.

dēpōnō, dēpōnere, dēposuī, dēpositum, lay aside, set aside.

facultās, -tātis, f., opportunity, chance.

genus, generis, n., kind, character, race, class.

igitur (adv.), therefore. Regularly postpositive. Cf. 412, 1 .

implōrō, -āre, -āvī, -ātum, implore, beg. Cf. 262.

initium, -ī, n., beginning; initium

faciō, make a beginning, begin. iste, ista, istud, that (of yours).

Cf. 31.

iūs, iūris, n., right, privilege.

neuter, neutra, neutrum, neither. obsidiō, -ōnis, f., siege.

pertineō, pertinēre, pertinuī, extend, pertain to (ad), concern. spatium, $-\overline{1}, \mathrm{n}$. , distance, space.

teneō, tenēre, tenuī, tentum, hold, keep, retain.

vìtō, -āre, -āvī, -ātum, avoid.

\section{LESSON XXII}

adferō, adferre, attulī, adlātum, bring to, carry to.

beneficium, -ī, n., good deed, kindness, service.

commemorō, -āre, -āvī, -ātum, mention.

cōnspectus, -ūs, m., sight, view.

dēfēnsor, -ōris, m., defender. 
iam, adv., now, already; nōn iam, no longer.

incolumis, -e, safe, unharmed, uninjured.

meum (tuum, nostrum, vestrum) est, it is my (your, our, your) duty. Cf. 100.

mulier, mulieris, f., woman. neque (nec)... neque (nec), neither . . nor. oppūgnātiō, -ōnis, f., attack, siege. pars, partis, f., part, direction. quoque (adv.), also. Postpositive. Cf. $412,1$.

removeō, removēre, remōvī, remōtum, remove.

senātus, -ūs, m., senate.

sententia, -ae, f., opinion.

suscipiō, -ere, -cēpī, -ceptum, undertake.

tamen (adv.), nevertheless, still, yet. üllus, -a, -um, any. Cf. 49.

\section{LESSON XXIII}

āmittō, āmittere, āmīsī, āmissum, lose.

capiō, capere, cēpī, captum, take, capture.

comparō, -āre, -āvī, -ātum, prepare, collect, provide.

coörior, coörīini, coörtus arise, sum

orior, orīrī, ortus sum up.

cum (conj.), when (cf. 277-282), although (cf. 315), since (cf. 292).

hiems, hiemis, f., winter.

insula, -ae, f., island.

maritimus, -a, -um, of the sea, on the sea, sea-, maritime, seacoast-. pãcō, -āre, -āvī, -ātum, subdue. prīvō, -āre, -āvī, -ātum, deprive. Cf. 149.

quam (with a superl.), as ... as possible; quam plūrimi, as many as possible.

regiō, -ōnis, f., region, district.

remittō, remittere, remīsī, remissum, send back.

renüntiō, -āre, -āvì, -ātum, report.

rürsus (adv.), again, back again.

statuō, statuere, statuĩ, statūtum, decide.

repentinus, -a, -um, sudden, unexpected.

subitus; -a, -um, sudden; subitō (adv.), suddenly.

tamen (adv.), nevertheless, still, yet.

\section{LESSON XXIV}

certāmen, certāminis, n., contest, fight, struggle.

clāmor, -ōris, m., shout, cry.

cohortor, -ārī, -ātus sum, address, encourage, urge.

cōnfectus, -a, -um, exhausted, worn out.

congredior, congredī, congressus sum, meet.

cōnsector, -ārī, -ātus sum, follow up, overtake.

cupiō, cupere, cupivī, cupītum, be eager. for. With acc.

dìmicō, -āre, -āvī, -ātum, fight.

égregius, -a, -um, unusual, exceptional; ēgregiē, adv., exceptionally (well).

èruptiō, -ōnis, f., sally.

excēdō, excēdere, excessī, excessum, go forth, withdraw. 
impediō, impedīre, impedīvī, impeditum, hinder, prevent, hamper.

inde (adv.), thence, then, from that place.

insidiae, -ārum, f. pl., ambuscade, treachery.

$\mathrm{me}$ in fugam dō, I betake myself in flight, I flee. Reflexive verb. nātūra, -ae, f., nature.

portō, -āre, -āvī, -ātum, carry. repellō, repellere, reppulī, repulsum, drive back, repulse, repel. vereor, verērī, veritus sum, fear. be afraid. Cf. 266.

vulnerō, -āre, -āvī, -ātum, wound, vulnus, vulneris, n., wound.

\section{LESSON XXV}

aditus, ūs, m., approach, access, arrival.

aliēnus, -a, -um, of another, unfavorable.

autem, but, however, moreover.

Postpositive. Cf. 412, 1.

comportō, -āre, -āvī, -ātum, bring together, carry, collect.

concīdō, concīdere, concīdī, concīsum, cut to pieces, kill, destroy. cōnsuēscō, cōnsuēscere, cōnsuēvī, cōnsuētum, become accustomed; in the perf. tenses, be accustomed, etc. Cf. 209.

soleō, -ēre, solitus sum, be accustomed.

deinde (adv.), then, in the second place, again, next.

dēserō, dēserere, dēserūi, dēsertum, abandon, desert.

discessus, -ūs, m., departure, withdrawal. dispōnō, dispōnere, disposūi, dispositum, place, station, place at intervals.

invītus, -a, -um, unwilling, against the will; unwillingly.

mātūrus, -a, -um, early, ripe.

opus, operis, n., task, work.

peragō, peragere, perēgī, perāctum, carry out, finish, complete.

perficiō, perficere, perfēcī, perfectum, complete, finish.

praesēns, praesentis, present, in person.

ultrō (adv.), voluntarily, of his own accord.

vacō, -āre, -āvī, -ātum, be vacant, be empty, be unoccupied.

vetus, veteris, old, former, ancient, of olden time.

vīs, (vīs), f., force, violence; virēs, -ium, f. pl., strength.

\section{LESSON XXVI}

accēdō, accēdere, accessī, accessum, come up, approach, come to.

administrō, -āre, -āvī, -ātum, manage, carry out, execute.

cōnfïrmō, -āre, -āvī, -ātum, strengthen.

dēcertō, -āre, -āvī, -ātum, fight it out.

hic (adv.), here.

iūdicō, -āre, -āvī, -ātum, judge, think.

lībertās, -tātis, f., lỉberty, freedom, privilege.

mandātum, $-\overline{1}, \mathrm{n} .$, command, order. nē ... quidem, not even. The emphatic words or words are placed between. Cf. 412, 2 . 
populor, -ārī, -ātus sum, lay|insistō, innsistere, institī, -, waste, devastate.

praesertim (adv.), especially. prope (prep. and adv.), near. quam primum, as soon as possible. reddō, reddere, reddidī, redditum, give back, return.

redeō, redīre, rediī, reditum, go back, return.

referō, referre, rettulī, relātum,

bring back, report.

respōnsum, -ī, n., reply, answer. socius, -ī, m., ally, comrade, associate.

subeō, subīre, subiī, subitum, undergo, endure. With acc. superior, superius, higher; loca superiōra, higher places, heights. tollō, tollere, sustulī, sublātum, take away, destroy, make way with.

unde (adv.), whence. vadum, -ī, n., ford, shallow.

\section{LESSON XXVII}

adeō, adīre, adiī, aditum, go to, visit, approach.

aestus, -ūs, m., tide.

ancora, -ae, f., anchor; in ancorīs, at anchor.

armō, -āre, -āvī, -ātum, arm.

compleō, complēre, complēvī, complētum, fill, cover.

ēgredior, ēgredī, ēgressus sum, go forth; nāvī (nāvibus) ègredior, disembark.

et . . . et, both ... and.

explōrō, -āre, -āvī, -ātum, examine, explore.

fïrmus, -a, -um, strong, firm; fïrmiter (adv.), firmly, strongly. stand, take one's position; fïrmiter insistō, gain a firm foothold.

fluctus, -ūs, m., wave.

inquam, I say; inquit, he says; inquiunt, they say. Used with direct quotations only and always postpositive. Cf. 412, 3 .

litus, litoris, n., shore.

nāvis longa, nāvis longae, f., war galley, ship of war.

onerärius, -a, -um, - of burden; nāvis onerāria, transport (ship). perturbō, -āre, -āvī, -ātum, disturb, throw into confusion.

portus, -ūs, m., harbor, port.

praetereā (adv.), besides, also, in addition.

undique (adv.), on all sides, from all sides.

urgeō, urgēre, ursī, -, press, press hard.

ventus, -ī, m., wind.

\section{LESSON XXVIII}

aqua, -ae, f., water.

cibus, $-\overline{1}, \mathrm{~m} .$, food.

cōnfertus, -a, -um, crowded.

cōnsistō, cōnsistere, cōnstitī, stop, take one's position, halt.

dēficiō, dēficere, dēfēcī, dēfectum, fail.

etiam (adv.), even, also.

fruor, fruī, frūctus sum, enjoy. Cf. 165.

fungor, fungī, fūnctus sum, perform. Cf. 165.

mē recipiō (recipere, recēpī, receptum), recover one's self; retreat. 
media nox, mediae noctis, f., | solvō, solvere, solvī, solūtum, midnight.

mūnus, mūneris, n., duty. nancīscor, nancīscī, nactus sum, secure, get.

nāvigō, -āre, -āvī, -ātum, sail, make a voyage.

loose; nāvem solvō, set sail. tempestās, -tātis, f., storm, weather.

trānsportō, -āre, -āvī, -ātum, carry over, transport. Cf. 6263.

potior, potīīi, potītus sum, get possession of, capture. Cf. 165. praeda, -ae, f., booty, spoil, plunder. reficiō, reficere, refēcī, refectum, repair.

ūtor, ūtī, ūsus sum, employ, enjoy. Cf. 165.

vēscor, vēscī, -, 一, eat, live on. Cf. 165. 


\section{REFERENCES TO GRAMMARS}

\section{PART I}

Note. All the constructions employed in the lessons are fully explained in the Elements of Syntax which comprises the first portion of this book. The following references are for use in connection with the grammars of Gildersleeve and Lodge (G.), Allen and Greenough (A.), Bennett (B.), and Harkness (H.), where such reference is desired. The references in parentheses are to the older edition of Allen and Greenough.

\section{- Lesson I. Tenses of the Indicative}

1. Present Tense: G. 227 ; A. 465 (276); B. 257 ; H. 532, 1, 2.

2. Imperfect Tense: G. 231 ; A. $470,471, a(277, a)$; B. 260, 1, 2 ; H. 534, 1-3.

3. Future Tense: G. 242 , R. 1 ; A. $472, b(278, b)$; B. $261,1,2$; H. 536 .

4. Perfect Tense: G. 235, 236, 1, 2, 239; A. 473 (279); B. 262, A, B; H. 537, 1, 2.

5. Pluperfect Tense: G. 241, 1, 2; A. 477 (280); B. 263; H. 539.

6. Future Perfect Tense: G. 244 ; A. 478 , N. $(281$, R.) ; B. 264, $a$; H. 540, 2.

Lesson II. Apposition; Predicate Nouns and Adjectives; Verbs of Naming, Choosing, etc.

1. Predicate Nominative: G. $205,206,211$; A. $283,284(185, a)$; B. $167,168,1,2, a, b ;$ H. $393,8,394$.

2. Two Accusatives with Verbs of Naming, etc.: G. 340 ; A. 392, $393(239,1, a)$; B. $177,1,2$; H. $410,1,2$.

3. Two Nominatives with Verbs of Naming, etc.: G. 206 ; A. 393, a $(239,1$, N. 2$)$; B. 177,3 ; H. $410,1$. 
Lesson III. Ablative Case: Means or Instrument; Agent; Specification; Accompaniment

1. Means or Instrument: G. 401; A. 409 (248, 8, c, 1-2); B. 218 ; H. 476.

2. Agent: G. 401 ; A. 405 (246); B. 216; H. 468.

3. Specification: G. 397 ; A. 418 (253); B. 226 ; H. $460,2,3$.

4. Accompaniment: G. 392 ; A. $413(248,7, a, b)$; B. 222 ; H. 473,1 .

Lesson IV. Indirect Object; Place To Which; Place From Which; Place Where; The Relative

1. Indirect Object: G. 345 ; A. $361,362(224-225)$; B. 187, 1; H. 424 .

2. Place To Which: G. $416,1,418,1, a, 2, a$; A. $426,2(258,2)$; B. $182,2,3$; H. 418, 491, I, 1 .

3. Place From Which: G. 390 ; A. $426,1(258,1)$; B. 229 ; H. 461, 491, 2.

4. Place Where: G. 385 ; A. $426(258, c)$; B. 228 ; H. $483,491,3$.

5. Relative Pronoun: G. 614; A. 305 (198); B. 250; H. 396.

\section{Lesson V: Expressions of Place; Locative Case}

1. Place Where: G. 385 ; R. 1,3 , N. 1, 386; A. 426,3 (258, c, $1, f, 1,2)$; B. $228,1, b$; H. 483 .

2. Locative Case: G. 411 , R. $1-3,386$, R. 1,2 ; A. $427,3, a, b, d$ (258, $c, 2$, N. 1, $d)$; B. 228, $a, c ;$ H. 483, 2, 484, 1, 2, N. 485, 2.

3. Place to Which: G. 416, 1, 418, 1, 337, R. 2, 4; A. 426, 2, 427, $2,428, a, b(258, b$, N. 2,3$)$; B. $182,2, a, b, 1, a, b ;$ H. 418, 2, 419, 1.

4. Place from Which: G. 390, 2, line 3, 391, R. 1, line 5; A. 426, $1,427,1,248, a, b(258,1, a$, N. 1$)$; B. $229,1, a, b ; 2$; H. 491, I, 2 , II, 2.

Lesson VI. Ablative and Genitive of. Description; Vocative Case

1. Ablative of Description (Quality): G. 400, R. 1; A. 415, a $(251, a)$; B. $224,1,3$; H. 473, 2, N. 1-2.

2. Genitive of Description (Quality): G. 365 , R. 2 ; A. $345, a, b$ $(215, a, b)$; B. 203, 1,$2 ;$ H. 440,3 .

3. Vocative Case: G. 33, R. 2, 73; A. 35, $f, 38, a, 49 c(31, e, 33, b$, $40, c)$; B. $17,25,1,350,3$; H. 402 , page 21 , footnote $2,83,5$. 
Lesson ViI. Direct Questions; Indirect Questions; Sequence of Tenses

1. Direct Questions: G. 454-456; A. 330-333, $a-b(210, a-e)$; B. 162, 1-2, $a, b, c$; H. 378, 2.

2. Indirect Questions: G. 467; A. 573, 574 (334); B. 300, 1; H. 649 , II.

3. Sequence of Tenses: G. 509-511; A. 482-484, 575 (285-286); B. 266-267, 268, 1 ; H. 543-545.

Lesson ViII. Time When; Time Within Which; Duration of Time; Extent of Space

$\left.\begin{array}{l}\text { 1. Time When: } \\ \text { 2. Time within Which: }\end{array}\right\} \begin{aligned} & \text { G. } 393 ; \text { A. } 423,1(256,1) ; \text { B. 230-231; } \\ & \text { H. } 486 .\end{aligned}$

3. Duration of Time: G. 336 ; A. $423,2(256,2)$; B. 181 ; H. 417.

4. Extent of Space: G. 335 ; A. 452 (257); B. 181 ; H. 417.

Lesson IX. Comparison: Ablative of Comparison; Degree of Difference

1. Ablative of Comparison: G. 296, R. 1; A. 406, 407, $a(247, a)$; B. $217,1,2$; H. 471, 1.

2. Plūs, Minus, Amplius, Longius: G. 296 , R. 4 ; A. $407, c$ (247, c); B. 217, 3; H. 471, 4 .

3. Degree of Difference: G. 403 ; A. $414, a(250$, R.); B. 223 ; H. 479, 1-3.

4. Time Before or After: G. 403, N. 4 (a); A. 424, $f, 1$ (259, d); B. 223,357 ; H. $479,3,488,1$.

Lesson X. Adjectives as Substantives; Possessive Adjectives; Personal and Reflexive Pronouns

1. Adjectives as Substantives: G. 204, N. 1 (a), (b), 2; A. 288, $a(188, a)$; B. $236,1-2 ;-H .494,1$.

2. Personal Pronouns: G. 304, 1-3, 308, 364; A. 293, $a$, 302, $a$ $(194, a, b, 197, a)$; B. 242, 1, 2; H. 500, 4, 440, N. 2.

3. Reflexive Pronouns and Adjectives: G. 309, 1; A. 299, $a$ (196); B. 244, 1, I; H. 502, 503.

4. Pronouns and Possessives of the Third Person: G. 308; A. 295, $c, 296,2(194, c, 195,1)$; B. 247, 2; H. 502, 503, 1. 
Lesson Xi. Ablative Case: Manner; Cause; Accordance

1. Manner: G. 399; A. 412 (248); B. 220, 1-2; H. 473, 3.

2. Cause: G. 408; A. 404 (245); B. 219, 2; H. 475.

3. Accordance: G. 408 , N. 1 ; A. $418, a(253$, N.); B. 220,3 ; H. $475,3$.

4. Review the References of Lesson III.

\section{Lesson XII. Indirect Discourse: Simple Sentences}

1. Infinitive in Indirect Discourse: G. 527 ; A. $578,581(336,1$, $2, a)$; B. 313,314 ; H. 641-642.

2. Tense of the Infinitive in Indirect Discourse: G. 530; A. 584, $a(336$, A) ; B. 317 ; H. $617-620$.

Lesson XIII. Accusative with Compound Verbs; Inner Object

1. Accusative with Compound Verbs: G. 331 , R. 1-3; A. $388, b$ $(237, d, 228, a)$; B. $175,2, a, 1)-2)$; H. 406.

2. Inner Object: G. $332,333,1-2$; A. $390, c(238, b)$; B. 176, $2-4$; H. 409, 1.

3. Multum Possum (or Valeō), etc.: G. -; A. -; B. -; H. -

Lesson XIV. Dative with Special Verbs; Dative with Compound Verbs

1. Dative with Special Verbs: G. 346 ; A. $367, a(227, a)$; B. 187, II, $a$; H. 426, 1, 2,4 .

2. Dative with Compound Verbs: G. 347 ; A. $370, a(228$, N.); B. 187, III, 1-2; H. 429, 1.

Lesson XV. Purpose Clauses; Result Clauses

1. Purpose Clauses: G. $445,1,3$; A. $530,1(317,1)$; B. 282, 1; H. 568.

2. Relative Clauses of Purpose: G. 630 ; A. $530,2(317,2)$; B. 282, 2 ; H. 590 .

3. Result Clauses: G. 552, 1-2; A. $537(319,1, a)$; B. 284 ; H. 470.

Lesson XVi. Dative Case: Reference; Purpose

1. Reference (Interest, Person for Whom): G. -; A. 376 (235); B. $188 ;$ H. - .

2. Purpose (Service, Thing for Which): G. 356 ; A. $382,1,2$ (233); B. 191, 1-2; H. 433. 
Lesson XVII. Substantive Clauses of Purpose and Result; INDIRECT REFLEXIVE

1. Substantive Clauses of Purpose: G. 546; A. 563, $a(331, a)$; B. $295,1, a, 2,4,5$; H. 564-565.

2. Substantive Clauses of Result: G. 553, 1-4; A. 568-571 (332, $a, 1-3)$; B. $297,1-3$; H. 571, 1-4.

3. Indirect Reflexive: G. 520,521 ; A. 300, 1, $2(196, a, 1-2)$; B. 244 , II, $a$; H. 504 .

\section{Lesson XVIII. Infinitives}

1. Subjective Infinitive: G. 419-422, 535; A. 452, 1-3, 454 (270, $1-3, b)$; B. 327,330 ; H. 615, 616, 1, 2.

2. Complementary Infinitive: \} G. 423, 532; A. 456-458 (271); B.

3. Objective Infinitive: $\} 328, \mathrm{I}-\mathrm{IV} ;$ H. 614 .

Lesson XiX. Partitive Genitive; Partitive Adjectives; Alius AND Alter

1. Partitive Genitive: G. $367-372$; A. $346, a, 1-3$ (216, $a, 1-3)$; B. 201, 1-2; H. 441-443.

2. Ablative for Partitive Genitive: G. 272, R. 2; A. 346, $c$ (216 c); B. -; H. 444, 1.

3. Partitive Adjectives: G. 291, R. 2; A. 293 (193); B. 241, 1-3; H. - .

4. Alius and Alter: G. 221, R. 1; A. 315, $c(203, a, c)$; B. 253, 1-5; H. 516.

Lesson XX. Dative with Adjectives: Genitive with Adjectives

1. Dative with Adjectives: G. 359 ; A. $383,384(234, a-b)$; B. 192, 1 ; H. 434.

2. Genitive with Adjectives: G. $374 ;$ A. $349, a(218, a-b)$; B. 204, 1; H. 450-451, 1, 2.

Lesson XXI. Gerund; Gerundive; Supine in -11m

1. Gerund as a Verbal Noun: G. 425-433; A. 501-502, 504-547 (295, 297-301); B. 338; H. 624-631.

2. Gerundive as a Verbal Adjective: G. 427-433; A. 500, 504547 (294, 297-301); B. 337, 8; H. 622-631. 
3. Gerundive Construction: G. 427 ; A. 503 (296); B. 338 ; H. $626,1$.

4. Gerund or Gerundive expressing Purpose: G. 428, R. 2; A. $504, b, 506(298, c, 300)$; B. 338, 1, c, 3; H. 634.

5. Supine in -um: G. 435 ; A. 509 (302); B. 340 ; H. 633.

6. Summary of Purpose Constructions: G. 544, R. 2; A. 533, $a-d$ (318); B. - ; H. 634.

7. Cf. Lesson XVI, Explanations.

Lesson XXII. Possessive Genitive; Predicate Genitive; Dative of the Possessor

1. Genitive of Possession: G. 362 ; A. 343 (214, a, 1); B. 198; H. $440,1$.

2. Possessive Adjective: G. 362 , R. 1 ; A. $343, a(214, a, 2)$; B. 243, 1; H. 440, N. 2, 176.

3. Predicate Genitive: G. 366 ; A. $343, b(214, c-d)$; B. 198,3 ; H. $439,3-5$.

4. Dative of the Possessor: G. 349, R. 2; A. 373, N. (231); B. 190 ; H. 430.

Lesson XXiII. Cum-Clauses: Temporal, Causal, Concessive

1. Cum-Temporal: G. 485,580 ; A. $545-547(325, a-c)$; B. 288 ; A, B, 289; H. 600, I, II.

2. Cum-Causal: G. 586; A. $549(326)$; B. 286,2 ; H. 598.

3. Cum-Concessive: G. 587 ; A. 549 (326); B. 309, 3; H. 598.

\section{Lesson XXIV. Participles}

1. Formation and Use of Participles: G. 438; A. 488-494 (289291); B. 337 ; H. 636.

2. Tenses of Participles: G. 282; A. 489 (290); B. 336; H. 640.

3. Participles used for Clauses: G. 593, 2, 609, 637; A. 496 (292); B. 337,2 ; H. 637-639.

\section{Lesson XXV. Ablative Absolute}

1. Review the References and Explanations of Lesson XXIV.

2. Ablative Absolute: G. 409-410; A. 419 (255); B. 227; H. 489.

3. Ablative Absolute without a Participle: G. 409; A. 419, a (255, a); B. 227,1 ; H. 489 .

4. Ablative Absolute for Clauses: G. 585, R., 593, 2, 609, 637; A. $420(255, c)$; B. 227,2 ; H. $489,1$. 


\section{Lesson XXVI. Passive Periphrastic}

1. Formation of the Passive Periphrastic: G. 129, 251, 1, 2; A. $194, b$ (129); B. 337, 7, b; H. 621, 1, 2.

2. Dative of Agent: G. 355 , R.; A. 374, $a$, N. 1 (232); B. 189, 1 ; H. 431.

3. Uses of the Passive Periphrastic: G. 521, 1, 2; A. 194, b (129); B. $337,8, b$; H. $621,1,2$.

Lesson XXVII. Complex Sentences in Indirect Discourse

1. Review the References of Lesson XII.

2. Complex Sentences in Indirect Discourse: G. 650; 653, 654; A. $580,585(336-336$, B) ; B. $314,317,318$; H. $642-644$.

Lesson XXVIII. Ablative with Ūtor, etc.; Review of Ablative Case

1. Ablative with Ütor, etc.: G. 407 , N. 3 ; A. 410 (249); B. 218, 1 ; H. 477, 1.

2. Review the References of Lessons III-V, VII-XI, which deal with the Ablative Case. 


\section{PART II}

\section{LESSON I}

\section{QUESTIONS: DIRECT AND INDIRECT - SEQUENCE OF TENSES - ACTIVE PERIPHRASTIC}

\section{REFERENCES :}

1. Direct Questions : 214-217.

3. Indirect Questions: 251.

2. Interrogative Pronouns: 44-45. 4. Sequence of Tenses: 242-246.

5. Active Periphrastic in Subordinate Clauses : 252.

\section{EXERCISE FOR WRITTEN TRANSLATION}

1. We know who the consuls were in the year of Catiline's conspiracy.

2. We likewise know which of the (two) consuls delivered the speeches against ${ }^{1}$ Catiline.

3. Why did Cicero accuse Catiline in such bitter terms ? ${ }^{2}$

4. Many Romans did not know why Cicero accused him in such bitter terms. ${ }^{2}$

5 a. Had Catiline marked out Cicero, the consul, for ${ }^{3}$ death?

b. Had not Catiline marked out Cicero, the consul, for $^{3}$ death?

c. Catiline had not marked out Cicero, the consul, for $^{3}$ death, had he?

6. After the speech many leading men asked Cicero whether Catiline had marked them out for ${ }^{3}$ death.

1 in with the accusative case. $3 \mathrm{ad}$.

2 " in such bitter terms" = "with such bitter words." 
7. Cicero knew what plan Catiline was adopting regarding the burning of the city.

8. Therefore he asked him whether he knew what the senate had decreed concerning other wicked citizens.

9. The senate knows what you have done hitherto, what you are now doing, (and) what you are going to do.

10. And so I do not understand why you are not-at-all moved by these men's knowledge of that conspiracy of yours.

11. Cicero then showed Catiline how severe a decree of the senate the consuls had against ${ }^{1}$ him.

12. All the citizens wished to learn what plan for ${ }^{2}$ their destruction you had already adopted, what plan you were adopting, (and) what plan you were likely to adopt.

13. It is easy to see which of the (two) consuls desired the conspiracy to be crushed.

$14 a$. Did the other consul desire Catiline to be put to death?

b. The other consul did not desire Catiline to be put to death, did he?

c. Did not the other consul desire Catiline to be put death?

15. The Roman people did not know whether the other consul desired Catiline to be put to death.

10 . What decree has the senate passed $^{3}$ against Catiline?

b. I learned what decree the senate had passed.

c. I shall tell you what decree the senate has passed.

1 in with the accusative case. " ad. " "What has the senate decreed." 
17 a. What decree is the senate passing against Catiline?

b. I learned what decree the senate was passing against Catiline.

c. I shall tell you what decree the senate is passing against Catiline.

18 a. What decree will the senate pass against Catiline?

b. Catiline did not know what decree the senate was going to pass.

c. Catiline does not know what decree the senate is going to pass.

19. I am going to tell you what forces he has collected.

20. Messengers inform me in what place these forces pitched camp, and how many new forces are arriving in that camp.

21. You all know whom that army is awaiting (as its) leader and commander.

22. Nevertheless I did not kill Catiline because I could not decide whether the citizens wished him to be killed.

23. For many knew neither what crimes he had committed nor what crimes he intended to commit.

24. Therefore Catiline was not moved by the consul's knowledge (of) what plan had been adopted.

\section{EXERCISE FOR ORAL TRANSLATION}

1. Who are the consuls? Which (of the two) is going to deliver the oration?

2. Has the other delivered an oration?

3. Has not the other delivered a speech? 
4. The other will not deliver a speech, will he?

5. Whom have they accused? Whom are they accusing? Whom will they accuse?

6. I know whom they have accused; whom they are accusing; 'whom they will accuse.

7. I knew whom they had accused; whom they were accusing; whom they would accuse.

8. He asks what the senate is going to decree.

9. He asks what crimes Catiline is committing.

10. He asks why Catiline has been accused.

Change "He asks" to "He was asking," " He will ask," "He asked," and "He had asked," and make the necessary changes in the subordinate clauses.

\section{LESSON II}

\section{GENITIVE CASE-PERSONAL PRONOUNS-DIRECT REFLEXIVES}

531. References :

1. Description (Quality): 101- 4. Genitive with Adjectives : 113$103,109$. 114.

2. Possession : $97-98,100,109$ 5. Personal Pronouns : 16-18.

3. Objective Genitive : 110-112. 6. Direct Reflexives : 19-20.

532. EXERCISE FOR WRITTEN TRANSLATION

1. Many sharers of Catiline's madness, men of great daring, have betaken themselves to his army in ${ }^{1}$ Etruria.

2. This army is not many days' journey ${ }^{2}$ distant from our city.

3. But Catiline, who remains with us, is plotting our destruction and (that) of the state, and has with him many associates.

$$
1 \text { "into." 2Cf. } 200 .
$$


4. Men of this kind have already attacked me in my ( own $)^{1}$ home by his command.

5. Hitherto I have defended myself from him and have checked all his attempts by my (own) watchfulless.

6. It is now the consul's (duty) to be forgetful of nimself and mindful of his (fellow) citizens.

7. On account of my good will toward my (fellow) sitizens, I am eager for the destruction of Catiline.

8. The consuls are conscious of their duty and will watch sharply for the safety of the citizens.

9. The conspirators have sent (as) commander of their forces in Etruria a man ${ }^{2}$ who is skilled in warfare.

10. Moreover, this same commander is actuated by hatred of you, senators, and of all good (citizens).

11. All good (citizens) fear and hate you, Catiline, more than they fear your army.

12. For they know where those forces are and can defend themselves and their city from them.

13. But who these conspirators in the city are they do not know, and so they fear them and their plots.

14. For even men of great courage fear an enemy of this kind.

15. Our city is full of wicked citizens who are eager for the destruction of all good (men).

16. Your consul has long ${ }^{3}$ been aware of Catiline's plans and has often defended himself from him.

1 Cf. 196, $a$.

2 "a man who" = eum qui.

8 " has long been" (and still is). Use iam diū with the present indicative. 
17. But now, senators, it is your (duty) to look out for your safety and (that) of your (fellow) citizens.

18. It is the consul's (duty), Catiline, to inform all the citizens about your plots.

19. You have been actuated by hatred of me, while I have been actuated by my love for my (fellow) citizens.

20. Catiline fixed a day for the murder of the chief men of the state.

21. But I learned about his plan and so he could not make a move against his city.

$22 a$. That night his associates in crime were with him at Laeca's (house). ${ }^{1}$

$b$. That night he summoned his associates in crime to him.

23. There he announced to them what plan he had adopted for ${ }^{2}$ my murder and the destruction of the state.

24. His plans have been announced to me; why does he not depart and betake himself to his army?

\section{EXERCISE FOR ORAL TRANSLATION}

1. I am going to surrender myself and all my (possessions) to him. Translate also in the second and third person singular:

2. We are going to surrender ourselves and all our (possessions) to them. Translate also in the second and third persons plural:

3. Catiline called his associates in crime to him.

4. I have sent his associates to him. I have sent those associates to him. 
5. His friends are sharers in this conspiracy. They a) e men of this sort. They are men of great boldness.

6. It is not my (duty) but the consul's to do this.

7. It is (the part) of folly to do this.

8. He is watching for our welfare and (that) of the siate.

9. Love of (one's) country; good will toward us; atred of us.

10. A man eager for war. A man skilled in war. A Inan conscious of (his) duty. A man forgetful of himself. A man mindful of his friends.

\section{LESSON III \\ GENITIVE WITH VERBS}

534. REFERENCES :

1. Verbs of Memory, etc. : 116.

2. Verbs of Reminding, etc. : 117 .

3. Verbs of Emotion, etc. : 118-119.

4. Verbs of Accusing, etc. : 121.

5. Verbs of Rating, etc. : 122.

6. Interest and Rēfert: 124 .

\section{EXERCISE FOR WRITTEN TRANSLATION}

1. All of the citizens remember your crimes, Catiline, and no one now pities you.

2. They recall the crimes which you have committed and cannot forget your conspiracy.

3. I have warned the senators of your conspiracy, and they will accuse you of murder.

4. Yet you are not ashamed of your wicked schemes, nor do you repent your deeds.

5. This we shall remember, and you will surely be condemned for your crimes.

6. I consider your private disgrace of little importance, but it is worth our while to recall your vices. 
7. Do you remember the crimes which you committed in your own home?

8. Do you forget the ruin which awaits you next month?

9. We remember these things and cannot pity you, for we are disgusted with your life and vices.

10. Moreover, it is to our interests (for) you to be killed, and it is to the interest of the state (for) this conspiracy to be suppressed.

11. All of the citizens hate and fear you, and it is of the greatest importance to them (for) you to depart from the city.

12. Therefore I give you this warning : leave the city and forget (your plans) of murder and burning.

13. All the senators remembered Catiline's crimes, and when he entered the senate they avoided him.

14. Nevertheless he did not repent his crimes, nor did he consider this (fact) of great importance.

15. Therefore we cannot pity him nor forget his vices.

16. It was to the interest of the senators to drive Catiline out of the city.

17. Cicero therefore accused Catiline for his wicked schemes.

18. Catiline was not ashamed to go to Lepidus, but he ${ }^{1}$ did not have pity on him. ${ }^{2}$

19. Cicero reminded Catiline of this and showed him of how great importance this was.

20. Every one was disgusted with Catiline's vices, and considered it of very great importance to avoid him.

1 ille. 2 is, 
21. This we can never forget, and we shall always re1 lember this conspiracy.

22. In this case it is worth while (for) us to remember vhat is to our interest.

23. Can you recall all the crimes which Cicero accused ' Jatiline of ?

24. Yet Catiline did not repent his deeds, nor did he zondemn himself for his schemes.

\section{EXERCISE FOR ORAL TRANSLATION}

1. I remember you. I remember all these (things). I remember all your words.

2. I forgot my speech. I forgot him. I forgot that.

3. I pity Catiline. Conjugate in the present tense of "pity." -

4. It is to the interest of the state. It is to Cicero's interest.

5. It is to my interest. Inflect this sentence, changing the person.

6. I consider this of little importance ; ... of great importance ; . . . of no importance.

7. We have warned the consul of this conspiracy. We have given him this warning.

8. We shall accuse this man of the crime; . . . of murder ; . . of the conspiracy.

9. We know what you are doing; . . . were doing; ... will do. We knew what you were doing; . . . had done; . . . were going to do.

10. A man of great daring; a man of daring. A man mindful of you, forgetful of himself. 


\section{LESSON IV}

\section{INFINITIVES : SUBSTANTIVE AND COMPLEMENTARY}

\section{ReFERENCES :}

1. Subjective Infinitive : $323-324$.

4. Placet and Vidētur : $325,1$.

2. Complementary Infinitive : 328-330. 5. Oportet : 325, 2.

3. Objective Infinitive : 331-332. 6. Licet and Necesse est: $325,3$.

7. Tense of the Auxiliary Verbs : 326 .

\section{EXERCISE FOR WRITTEN TRANSLATION}

1. It pleases the senate, Catiline, that you should go into exile, but you seem to be unwilling to obey.

2. Why do you hesitate to set out whither you yourself desire to go?

3. We surely will not permit you, who desire to destroy the city, to remain.

4. For we must defend our native land from those who have attempted to destroy it.

5. You might have gone out of the city before, but you preferred to await my command.

6. I ought to have driven you out of the city before, but the senators have prevented me from doing this.

7. Now, however, I have decided to free the city from danger, and I am preparing to strip you of your arms of boldness.

8. You ought to obey the consul, but it is difficult to force you to desist from your crimes.

9. I, the consul, order you to depart, but you are accustomed to do what you wish. 
10. Therefore it has seemed best for the senate to comil you to depart and free us from fear.

11. You do not dare, do you, to delay if the senators f orbid you to remain?

12. I could have ordered you to be killed, but I preferred that you should go into exile.

13. Cicero ought to order all of Catiline's followers to leave the city.

14. He could have done this before, but he was preparng to find out what they were trying to do.

15. For Catiline had dared to gather together a band of wicked men and desired to lay waste the city.

16. It was, therefore, a very difficult (task) for Cicero to suppress the conspiracy.

17. This we may understand from Cicero's speech, for he tells us how he tried to check Catiline's attempts.

18. Still Cicero did not hesitate to resist Catiline, nor did he cease to lay bare his plans.

19. For he had decided to free the city from danger and was prepared to order Catiline to be killed.

20. Therefore it seemed best to Cicero to call the senate together.

21. But he could not prevent Catiline from coming into the senate with the rest of the senators.

22. Therefore it pleased Cicero to deliver the speech in which he ordered Catiline to leave the city.

23. "This man," he said, "desires to deprive us all of life ; therefore, I forbid him to remain."

24. "He has begun to form a conspiracy, and therefore he must be driven into exile." 
539. EXERCISE FOR ORAL TRANSLATION ative.

1. I ought to do this. Conjugate in the present indic-

2. I might have done this. Conjugate in the tense indicated.

3. We shall have to do this. Give in three ways.

4. May I remain at home? Conjugate in the present indicative interrogative.

5. It seems to be easy to prevent him from going.

6. It is my plan to remain in the city.

7. I am ashamed to have done this. Conjugate "I am ashamed" in the present.

8. He seems to have been driven into exile. She seems, etc.

9. I repent of having said that.

10. It is to your interest to come at once.

\section{LESSON V}

INDIRECT DISCOURSE: SIMPLE SENTENCES-INDIRECT REFLEXIVES

540. REFERENCES :

1. Indirect Discourse : 333-336.

2. Tenses of the Infinitive in Indirect Discourse : 337-340.

3. The Future Infinitives, Substitutes for : 341-343.

4. Direct and Indirect Reflexives : 21-23.

541. Explanations :

The indirect reflexive is used in indirect discourse when referring to the subject of the verb of saying, etc.

Puer dīcit $s \bar{e}$ nōs vīdisse, the boy says that he saw us.

Puer dicit eōs $s \bar{e}$ viddisse, the boy says that they saw him.

Here sē refers to the subject of the verb dicit. 


\section{EXERCISE FOR WRITTEN TRANSLATION}

1. Catiline has attacked the state, is already a publicenemy, (and) will soon be a commander in the enemy's camp.

2. All Italy declares that Catiline has attacked the state, that he is already a public-enemy, (and) that he - will soon be a commander in the enemy's camp.

4. 3. Catiline himself confessed that he had attacked the state, that he was a public-enemy, (and) that he would soon be a commander in the enemy's camp.

4. Many citizens saw that he was being waited-for (as) a leader of the war.

5. These (men) did not think that he ought to go forth unharmed.

6. They say that so bold a leader of desperate men will not go to Marseilles (as) an exile.

7. Cicero admits that the senate has passed a decree against Catiline, and that he ought to be punished with death.

8. He says, however, that the conspiracy cannot be suppressed by the death of (its) leader.

9. He knows that the rest of the conspirators will not desist from their hope on account of the death of Catiline.

10. He hopes that Catiline and his associates will be killed in battle.

11. Cicero promised at the same time that the consuls would not cease to watch for the safety of the state.

12. Many citizens who had realized the danger now rejoiced that their lives ${ }^{1}$ had been saved.

1 Use the singular. The plural usually means "biographies." 
13. The consul knows that an army has been collected, and that the leader will soon set out to that army.

14. Many (men) were saying that the consul ought to defend the citizens.

15. The consul hoped that Catiline would go forth and take all his associates with him.

16. He leven hoped that upon their departure the whole conspiracy mould be suppressed.

17. He said that the city could not be captured by that army of Catiline.

18. He asserted that many of the citizens did not believe that a conspizacy had been formed.

19. He said that for this reason the number of conspirators would increase every day.

20. The orator then explained that Catiline was not only a leader of conspirators, but also a companion of all desperate citizens.

21. And he said that not only during this year, but for several years, he ${ }^{1}$ had tried to destroy the state.

22. Catiline then rose and said that he was not actuated by hatred of his (fellow) citizens.

23. He said that he was a senator and more desirous of the. welfare of the state than Cicero himself.

24. The senators, however, were unwilling to endure him, and declared that he was an enemy of all good (men).

\section{EXERCISE FOR ORAL TRANSLATION}

1. He is defending his town from them. He says that he is defending his town from them.

2. I believe that he was defending his town from the 
enemy. I believed that he was defending his town from the enemy.

3. They did not realize the danger. Put this into indirect discourse after (a) crēdō ; (b) crēdidi.

4. They said that they had not realized the danger.

5. I promise to surrender my town to him. Conjugate in the present.

6. They promised that they would surrender their town to him.

7. I rejoice that he has saved me. I rejoiced that he had saved me.

8. I do not believe that he will be punished with death.

9. I did not believe that he would be punished with death.

10. I hope that I shall not repent of my bravery. Conjugate in the present.

\section{LESSON VI}

\section{INDIRECT DISCOURSE: COMPLEX SENTENCES}

544. REFERENCES :

1. Review the References of Lesson V.

2. Complex Sentences in Indirect Discourse : 347-348.

3. General Rules for Sequence of Tenses : 242-246.

4. Exceptional Sequence: $248,250$.

545. EXERCISE FOR WRITTEN TRANSLATION

1. Cicero believed that a man who had been accused in such bitter terms would not remain at Rome.

2. For the senators believed that all those (things) which Cicero had said about Catiline were true.

3. Cicero himself had said that all who heard his bitter words, and were silent, approved (of them). 
4. We learn that Catiline, though he had begun to reply, was prevented by the cries of the senators.

5. Catiline then realized that he would accomplish nothing at Rome, since the leading men considered him an enemy.

6. He will therefore go forth from Rome and return with an army when his associates summon ${ }^{1}$ him.

7. He promised his associates that he would return to Rome when they summoned ${ }^{2}$ him.

8. He promises his associates that he will return when they summon ${ }^{2}$ him.

9. He then promised that he would give great rewards to those who carried out ${ }^{2}$ his plans well.

10. He said that great rewards would be given to those who carried out ${ }^{2}$ his plans well.

11. Finally he asserted that, although he was being driven from Rome, he would not desist from his attempt.

12. His associates replied that everything which he had ordered would be done.

13. The consul learned that Catiline, when he had given these commands, ${ }^{3}$ had set out to the camp of Manlius.

14. He therefore announced to the people that, since Catiline had gone away, they were free from danger.

15. Now surely he is grieving that the city from which he has been driven has escaped his plots.

16. When he arrives ${ }^{1}$ at the camp of Manlius, he will be the commander of that army.

\footnotetext{
1 Cf. 213.

${ }^{2}$ Cf. 250.

8 "when he had commanded these things."
} 
17. Many believe that when he arrives ${ }^{1}$ at that camp, he will be the commander of that army.

18. Others knew that when he arrived ${ }^{1}$ at that camp he would be chosen (as) commander of that army.

19. For this reason many are saying that the consul ought to have arrested the man who has gone away.

20. Cicero replied that many citizens did not consider the man who had gone away an enemy (-of-the-state).

21. Cicero had always hoped that Catiline would take with him those desperate men whom he especially loved.

22. For he understood that the city could be burned by a few desperate men who were inclosed within the gates.

23. But he considered that an army which was (composed) of desperate men was to be despised and not ${ }^{2}$ feared.

24. "For," said Cicero, "I have learned that our forces in Gaul ${ }^{3}$ are stronger than Catiline's army."

\section{EXERCISE FOR ORAL TRANSLATION}

1. I think that the man whom you have accused will withdraw.

2. I thought that the man whom you had accused would withdraw.

3. I believe that he withdrew because he was afraid.

4. All whom he summons will go to his camp.

5. He says that all whom he summons will go to his camp. He said that all whom he summoned would go to his camp.

1 Cf. 250.

2 " and not" = neque.

${ }^{3}$ cōpiae Gallicae. 
6. The messenger said that all who were our allies had been defeated.

7. I hope that all who do this will be driven out of the city.

8. I hoped that all who did this would be driven out of the city.

9. I hope that he will not desist from that which he has begun.

10. I hoped that he would not desist from that which he had begun.

\section{LESSON VII}

\section{CONDITIONS: LOGICAL AND IDEAL}

547. ReFereNCES :

1. General Statements: 298-300. 2. Logical Conditions: 301-302.

3. Ideal Conditions: $303-304$.

548. EXERCISE FOR WRITTEN TRANSLATION

1. If Catiline has departed and is now outside the walls, we are safe.

2. But if his followers remain with us, we shall not be freed from danger.

3. If they should go forth, you would all be able to see that a great conspiracy has been suppressed.

4. If they do not follow Catiline, I shall order all the leaders to be arrested.

5. If any one thinks that Catiline was driven into exile by me, he is much mistaken.

6. For he was a very timid man if he was unable to endure the words of the consul.

7. If he should go to the camp of Manlius, he would be received with great joy. 
8. But if he takes fright and changes his intention, re will be said to have been driven into exile by me.

9. Unless I am much mistaken, however, Catiline is now betaking himself to the camp of Manlius.

10. If any of his accomplices in crime remain in the city, we shall have to watch carefully.

11. If all of these should go to Manlius, I for my part should not complain.

12. If it can be done in any way, and if they are willing to obey me, I shall warn these men.

13. If you wish, senators, I will tell you what we must do now.

14. If any one of you thinks that Catiline has gone into exile, he is very much mistaken.

15. For if that scoundrel should do that, he would lose all prestige.

16. But if he goes to Etruria, he will be placed in charge of the troops of Manlius.

17. Unless, however, he takes all of his followers with him, we shall still be in danger.

18. But if his associates in crime should be driven out with him, we should be freed from fear.

19. Unless we drive these men out or arrest them, within three days you will see Catiline's army.

20. Unless any one of you is unwilling, I shall try to force them to go out of the city.

21. If that cannot be done, I shall order them all to be arrested.

22. But if Catiline should lead an army to Rome, we should have to defend the city. 
23. That can easily be done, if you will all believe me and follow my advice.

24. But we must all realize how great a conspiracy has been revealed if we wish to save the state.

\section{EXERCISE FOR ORAL TRANSLATION}

1. You are mistaken if you say that. Put this condition in present, past, and future time.

2. If you do this, you are my friend. If you will do this, you will be my friend. If you do this, you will be arrested.

3. If he comes, we shall welcome him. If he should come, we should welcome him.

4. Should he go into exile, he would be safe.

5. If anything should happen, he would come to me. If any one does this, he will be killed.

6. I will come, if you wish; but if you prefer, I will send my brother.

7. If he comes, I know that he will tell me.

8. I said that if he was in the city, I was safe.

9. I believe that if he is in the city, we are safe.

\section{$\checkmark$ LESSON VIII}

\section{CONDITIONS : UNREAL}

550. REFERENCES :

1. Unreal Conditions : 305-307. 2. Mixed Conditions : 308.

3. Indicative in Unreal Conditions : 309-310.

551. EXERCISE FOR WRITTEN TRANSLATION

1. If Catiline's followers were honorable men, they would not be so greatly in debt. ${ }^{1}$ 
2. Nor would they now be in so great danger if they aad been willing to listen to me.

3. Now if they should gain the honors which they lesire, they would expect to be kings.

4. Yet if they had gained those honors which they wished, they would not have kept them.

5. For if they had become masters of the situation, it would have been necessary for them to surrender their power to some gladiator.

6. If they wished to live honorably, they would not be preparing to attack the state.

7. Had I been able, I should have arrested these men.'

8. But if you did not believe me at that time, who will believe me now?

9. Moreover, if you do not now see that a conspiracy has been formed, how can I persuade you?

10. If I had arrested Catiline, I should not have been able to restrain his associates in crime.

11. At last, however, Catiline has gone, and if you will aid me, I shall be able to thwart his plans.

12. But if you should fail me in (the midst of) these dangers, Catiline would capture Rome.

13. If Catiline's associates in crime had gone out with him, the state would have been freed from fear.

14. But if Cicero did not see that a conspiracy is being formed, he would not be saying this.

15. If he had not driven Catiline out of the city, we should still be in danger.

16. For if he had not done this, Catiline would have killed us all. 
17. If the leaders of the conspiracy get control of affairs, it will be necessary for us to flee.

18. We should have been killed already if the consul had not discovered these plots.

19. If Catiline were not afraid, he could return to Rome at once.

20. But if he should lead his army against us, we should be able to defeat him.

21. For if he was not able to attack us before, he will not dare to try (it) now.

22. If the consul had known of Catiline's plots, he might have killed him.

23. Had he done this, however, the rest of the band of conspirators would have remained.

24. Should Catiline return now, he would be killed.

552. EXERCISE FOR ORAL TRANSLATION

1. If he comes. If he should come. If he were coming. If he had come.

2. If you wish, you may go. Conjugate in the present.

3. If you had wished, you might have gone. Conjugate in the tense indicated.

4. If Caesar is leading, we are safe. Give in all six forms of conditions.

5. If we had fought more bravely then, we should now be safe.

6. If you were here at that time, you saw him.

7. If you were there, you would see him.

8. Had you asked me, I should have aided you.

9. Were you a friend, I should tell you.

10. I should have aided him, if I had been able. 


\section{LESSON IX}

\section{DELIBERATIVE QUESTIONS - RHETORICAL QUES- TIONS-DOUBLE QUESTIONS}

553. REFERENCES:

1. Deliberative Questions : 218. 3. Double Questions : 221, 222.

2. Rhetorical Questions : 219 . 4. Sequence of Tenses : 249.

\section{EXERCISE FOR WRITTEN TRANSLATION}

1. Formerly wicked citizens were punished with death; are we, the consuls, to endure this leader of conspirators?

2. Why should I hesitate to punish him? What am I to do?

3. If I punish him as he deserves, will the senators approve or not?

4. Cicero found out by (means of) the first oration whether the senators feared Catiline or not.

5. You consider him an enemy, senators. Do you wish him to be killed or sent into exile?

6. I myself am uncertain (as to) whether he ought to be killed or sent into exile.

7. Catiline has indeed gone away in safety. ${ }^{1}$ But what was I to do? Was I to put him to death?

8. If I had put him to death, would you now be calling me a watchful or a cruel consul ?

9. Many, too, would be asking ${ }^{2}$ me whether he is wicked or very unfortunate.

10. Many would have pitied $^{2}$ him. Who, therefore, can accuse me of too great leniency?

11. Many are now making this inquiry, ${ }^{3}$ "Has Catiline gone to Manlius or not?"

1 Use the adjective "safe."

${ }^{2}$ Cf. 234.

${ }^{3}$ Cf. $65,471$. 
12. For it greatly concerns the state, whether he has gone or not.

13. Many are asking whether he has gone into exile or not. But who believes that he has gone?

14. Does any one think that Manlius has collected that army on his own account ? ${ }^{1}$

15. We ought rather to ask whether his associates in crime will follow him or not.

16. Who would have thought that the departure of one man could so relieve the state?

17. But if the rest remain, what plan shall we adopt for the safety of the state?

18. Consider now whether the consuls and all good (men) or Catiline and his associates ought to conquer.

19. Ought honor and justice or madness to prevail in this state?

20. Why should so many rich men have joined themselves to that band of wicked (men)?

21. Do they hope for the glory of war or for a cancellation of debts from Catiline's conspiracy?

22. But why should any one hope to gain glory from such a war?

23. Why should rich men hope that Catiline will free them from debt rather than from their possessions?

24. Can these men be saved from so great madness or not?

\section{EXERCISE FOR ORAL TRANSLATION}

1. Will he remain or go into exile?

2. Will he go into exile or not? 
3. Many were asking whether he would go into exile or not.

4. He asked whether they praised his foresight or (his) leniency.

5. Who can endure the daring of that man?

6. What shall I do? Shall I allow him to remain?

7. What was I to do? Was I to permit him to remain?

8. Why should I not rejoice that we have driven him out?

9. Who would have thought that he would go into exile?

10. Why should I be ashamed of my deeds?

\section{LESSON X}

\section{THE DATIVE CASE-OPUS EST AND USUS EST}

556. REFERENCES:

1. Indirect Object: 78.

2. With Special Verbs : 79-82.

5. Purpose (Service) : 90-91. Cf.

3. With Compound Verbs : 83-84.

Cf. 475. 483.

6. With Adjectives : $92-96$.

7. Dative of Possessor : 85-86.

4. Dative of Reference (Interest) : 8. Opus est and Ūsus est : 155-156. 87.

\section{EXERCISE FOR WRITTEN TRANSLATION}

1. Cicero had looked-out-for-the-interests-of the state and had thwarted all Catiline's plans.

2. Often had he snatched from his ${ }^{1}$ hands the sword which he knew was threatening him.

3. Finally he said that Catiline's crimes could no longer be pardoned nor (Catiline) himself spared.

4. Then at last it seemed best to Catiline to obey the consul and depart from Rome. 
5. But many (men) like him had remained at Rome and were threatening the city.

6. Therefore even greater dread was inspired in the consuls.

7. For all good (citizens) had hoped that these men would withdraw to the camp of which Catiline was in charge.

8. Cicero thought that the city had sufficient protection, for he knew that it had many brave citizens.

9. Nevertheless there remained before his ${ }^{1}$ eyes the sight of these men ruling in the city.

10. He well understood, therefore, that the city had need of watchful consuls.

11. Then, indeed, he prepared to resist those men who were trying to injure the state.

12. Soon that happened which was suited to his plans and which furnished him the evidence which he needed.

13. The conspirators have been arrested, Romans, and the city has been rescued from their ${ }^{1}$ hands.

14. By my efforts your city has been saved and you will not be harmed by these men.

15. I shall now explain to you how you have been served by your consul.

16. I was not believed by you when I told you that a conspiracy had been formed.

17. I realized, however, that you would look out for your (own) safety when you were given evidence concerning the conspiracy. 
18. I learned that the ambassadors of the Allobroges had had some business with the leaders of the conspiracy.

19. The conspirators thought that men of this nation would be friendly to those who were harming us.

20. Letters from Catiline were therefore intrusted to these men who were about to return home.

21. They delayed two days because Cethegus had a dispute with the rest of the conspirators.

22. Therefore I summoned those men whose help I needed, and instructed them how they could secure the letters.

23. If Cethegus had not had the dispute with his associates, I could not have secured those letters.

24. Surely the conspirators would not have handed over these letters to the Gauls unless the gods had taken away their ${ }^{1}$ wisdom.

\section{EXERCISE FOR ORAL TRANSLATION}

1. I have need of your help. Conjugate in the present.

2. I needed your protection. You needed my protection. They needed our protection.

3. You are a help to me. You have come to help me.

4. My friends believe me. Conjugate in the present.

5. I have been pardoned by my friends. Conjugate in the perfect.

6. They have put Crassus in command of these forces. Crassus has been put in command of these forces.

7. Crassus is in charge of the army.

8. Men like the conspirators are not friendly to us.

9. They have cut off the supplies of our army. ${ }^{1}$

1 Do not use the genitive. Cf. 87 . 


\section{LESSON XI}

PURPOSE CLAUSES: PURE, RELATIVE, AND SUBSTANTIVE

559. REFERENCES :

1. Purpose Clauses : 253-254.

2. Relative Clauses of Purpose : 255-256.

3. Substantive Clauses of Purpose : 261-263.

560. EXERCISE FOR WRITTEN TRANSLATION

1. Letters had been given to the ambassadors of the Allobroges to carry to their (people).

2. In these letters Cethegus had asked the Allobroges to carry out his instructions.

3. Therefore I ordered these letters to be brought forth and read.

4. Then I urged the arrested men to confess and warned them to tell the truth.

5. Finally Cethegus confesses, but begs us not to kill him.

6. Then, in order that the whole matter might be brought to light, Lentulus was led in.

7. At first he denies everything and demands to be set free.

8. Finally, however, he confessed that he had tried to persuade Catiline to return.

9. Now, fellow-citizens, that you may more easily understand what has been done, I shall explain to you what the senate has decreed.

10. First the senate resolved that thanks should be extended to me. 
11. Then the senators decreed that the praetors should se praised.

12. Finally they instructed the magistrates to lead to prison those who had been arrested.

13. The leaders of the conspirators had sent Volturcius with the Gauls to carry instructions to Catiline.

14. Cicero therefore urges him to tell what he knows about the case.

15. He said that the conspirators had asked Catiline to return to Rome at once.

16. Then the senate commanded that Volturcius should be pardoned in return for this evidence.

17. To make a long story short, ${ }^{1}$ Cicero persuaded all of the leaders of the conspirators to confess.

18. Then he permitted them to be given over into custody.

19. The senate also demanded that Lentulus resign his office so that the law might be obeyed.

20. A decree was also passed ${ }^{2}$ that a thanksgiving should be ordained ${ }^{3}$ to the immortal gods.

21. All of these things have been done, that you might live more safely hereafter.

22. For I have provided that the city should have sufficient protection.

23. But it is your (duty) to see to it that these men be punished.

24. Then you will be able to prevent wicked men from forming conspiracies.

1 "That it may not be long." 2 "It was also decreed." 3 cōnstituō. 


\section{EXERCISE FOR ORAL TRANSLATION}

1. Caesar sent soldiers to aid the tenth legion. Give in three ways.

2. I order you to go at once. Give twice, using iubeō and imperō.

3. He urges us to do this. Give a synopsis of this sentence.

4. They will not permit us to stay. Give twice, using permittō and sinō.

5. He begged us to protect him, but we persuaded him to defend himself.

6. I shall send you aid, that you may do this more easily.

7. I advise you to tell me, but. I warn you not to tell my brother.

8. I have been ordered to do this. Use iubeō and conjugate in the perfect.

9. I have been ordered to do this. Use imperō and conjugate in the perfect.

10. I asked him not to tell any one. I asked him to say nothing.

\section{LESSON XII}

\section{RESULT CLAUSES-PURPOSE AND RESULT CON-} TRASTED.

562. REFERENCES :

1. Result Clauses : 258-259, $a$.

2. Sequence of Tenses : $260,247$.

3. Substantive Result Clauses : 264.

4. Purpose and Result Contrasted : 265. 


\section{EXERCISE FOR WRITTEN TRANSLATION}

1. At last, fellow-citizens, we have brought it about $\mathrm{t} l$ at the wicked leaders of this conspiracy were arrested.

2. Everything has been so managed that no one of them escaped.

3. We must now see to it that no one hereafter may fiorm a conspiracy against the state.

4. To leave out of consideration all the other things, the immortal gods have so aided us that nothing seems to have been neglected.

5. Who, then, ${ }^{1}$ can be so mad as to deny that the imroortal gods protect this city?

6. We cannot recall the dangers which we have escaped without feeling grateful to them.

7. It remains, therefore, for us to urge the senate to decree a thanksgiving to the gods.

8. I shall see to it that nothing is overlooked by the senate which concerns the welfare of the state.

9. For it happens that nothing which these conspirators have done has escaped my notice.

10. The outcome will be that we shall never again be in fear of a conspiracy.

11. For I shall bring it about that no one hereafter will dare to attack the state.

12. Added to this is the fact that all classes are now united for the safety of the republic.

13. Cicero had managed everything in such a way that all of the leaders of the conspiracy were arrested. 
14. In this way he had brought it about that the entire conspiracy was suppressed.

15. He could not accomplish this, however, without exposing himself to great danger.

16. For it happened that several of the conspirators were very powerful men.

17. Added to this was the fact that many of the senators did not believe what Cicero said.

18. However, at last he made the senate understand that a great conspiracy had been formed.

19. Then the senate decreed that the consul should see to it that no one of the leaders should escape.

20. The result was that no one of the conspirators was able to go to Catiline.

21. None of the senators was so bold as to prevent Cicero from arresting the conspirators.

22. Thus it happened that no harm was done ${ }^{1}$ to the republic by the conspirators.

23. Cicero, therefore, urged the citizens never to forget the kindness of the immortal gods.

24. For the gods had provided that no harm should be done ${ }^{1}$ to their temples and the city by the conspirators.

\section{EXERCISE FOR ORAL TRANSLATION}

1. I make you understand. Give a synopsis of this sentence.

2. The consul warned Catiline not to remain in the city. The result was that he did not remain.

3. Cicero ordered that no one should depart. Thus it happened that no one departed. 
4. I beg of you to say nothing of this. It remains for you to say nothing of this.

5. You cannot do this without harming me.

6. I beg of you not to do this again. I will bring it i bout that you will never do this again.

7. Cicero had the good fortune to be in Rome at that time.

8. But unfortunately it happened that his friend was cway.

9. Caesar sent soldiers to aid his allies. Give in three ways.

10. I urged him not to bring it to pass that the citizens should not come.

\section{LESSON XIII}

\section{COMMANDS - PROHIBITIONS - EXHORTATIONS AND ENTREATIES}

565. ReFERENCES :

1. Imperative Mood : 237-239.

2. Prohibitions (Negative Commands): 240.

3. Hortatory (Jussive) Subjunctive : 236.

4. Table of Commands, etc.: 241.

566. EXERCISE FOR WRITTEN TRANSLATION

1. Remember, fellow-citizens, that the greatest conspiracy within the memory of man has been suppressed.

2. Catiline had said to his companions in crime, "Let Cicero be slain in his ${ }^{1}$ (own) home."

3. But Cicero escaped and said to Catiline, "Go forth from the city, Catiline; betake yourself to the camp of Manlius." 
4. Lead out with you all your followers and make war on your city; do not remain within (its) walls.

5. Depart and free us from fear, for know that we fear wicked citizens more than an army of the enemy.

6. Let me not again hear that your associates are trying to harm this city.

7. But if $\mathrm{I}$ do hear this, let them not hope to escape punishment.

8. Remember, citizens, that the leader has left Rome, but do not forget that the rest have remained.

9. Let us not forget that the gods have saved us from murder and our city from destruction.

10. Let us admit that (it was) they (who) persuaded the conspirators to intrust their letters to the Gauls.

11. These commands were given ${ }^{1}$ to the Gauls (when) arrested: "Tell all that you know; do not fear punishment."

12. The senate has passed these decrees: ${ }^{2}$ First let Lentulus and his associates be led to prison.

13. Then let thanks be given to the consul and other patriotic citizens.

14. Finally let a thanksgiving to the gods be celebrated in all parts of the city.

15. Now, citizens, let us compare this thanksgiving with all others and admit that none ${ }^{3}$ was more just.

16. Recall how many portents were seen and how many images of the gods were overturned at that time.

1 "These (things) were commanded."

${ }^{8}$ What gender?

2 "'has decreed these (things)." 
17. Do not deny that the gods have warned us of the d ungers which threatened us.

18. Wise men at that time gave us this advice: ${ }^{1}$ Plac tte the gods, and in that way avert civil war.

19. Make an image of Jupiter and set it up near the t sum; let it behold the punishment of the enemies of the state.

20. Now, Romans, recall (the fact) that to-day that statue was set up and the conspirators led to punishment.

21. Know that all these (things) have been managed not by me but by the immortal gods.

22. Nevertheless, fellow-citizens, remember your consul and the many things which he has accomplished.

23. In return for all these things, let the memorials of my glory be stored up in your minds.

24. Let me therefore not be harmed by my enemies on account of my deeds.

\section{EXERCISE FOR ORAL TRANSLATION}

1. Make war on your enemies. Translate in the singular and plural.

2. Do not make war on your friends. Translate in the singular and plural.

3. Do not be afraid; tell us everything. Translate in the singular and plural.

4. Depart and lead with you all your friends. Translate in the singular and plural.

5. Do this at once; let us no longer live in (a 'state of) dread.

6. Let us remember all these (things). 
7. Let them not delay longer with us.

8. Let him depart at once.

9. Remember that all your (fellow) citizens fear you.

10. Know that we are all (in and plural. a state of) dread.

Translate in the singular a state of) dread.

\section{LESSON XIV}

\section{CHARACTERISTIC CLAUSES-CLAUSES AFTER VERBS OF FEARING}

568. REFERENCES :

1. Characteristic Clauses : 274-276. 2. Verbs of Fearing: 266-268.

569. Explanations :

Note the difference between the English and the Latin idiom in the following examples of characteristic clauses: Dïgnus est qui mittātur, he is worthy of being sent (worthy who should be sent).

Idōneus est quī dēligātur, he is a suitable man to be chosen (suitable who should be chosen).

Vir nōn est eius modĩ qui metuat, he is not the sort of man to fear, he is not a man of such a sort as to fear (of such a sort who should fear).

570. EXERCISE FOR WRITTEN TRANSLATION

1. We now hold (in our power), senators, those who are worthy of the severest punishment.

2. And we must decide to-day whether these men are worthy of being punished with death or not.

3. Decide boldly; be not afraid that you may gain unpopularity by your acts.

4. There are indeed (some) who favor the conspirators, but these are not worthy of being feared.

5. There are here at Rome many wicked citizens who wish these men to be freed from all punishment. 
6. But there is no good citizen who will not approve (of) a courageous decision.

7. Unless you decree a severe punishment, you will have to fear that good citizens will not consider you patriotic.

8. Do not be afraid that I shall not be able to carry out your decrees.

9. For the leaders of the conspiracy were the only ones who were able to carry out Catiline's plans.

10. These men have been arrested and there is no one else of that band who is suitable to be put in charge of so great a conspiracy.

11. For this reason, senators, there is nothing which the rest of the conspirators can do to hinder me.

12. Are you afraid that the state as a whole will not approve of your acts?

13. There are some who think that I am not deserving of blame, but of praise for my acts.

14. Nevertheless there are many who fear that I shall be harmed by the friends of the arrested conspirators.

15. For their friends are such (men) as do not hesitate to stir up hatred against their enemies.

16. I myself am not afraid to endure whatever fortune ${ }^{1}$ be set before me.

17. But I am afraid that my wife and children may be unable to escape harm.

18. And I am not such (a man) as not to be moved by the dangers which threaten them.

1 " to endure fortune, whatsoever is set before me." 
19. There is no longer a foreign nation which can make war on us.

20. Wicked citizens here at Rome are the only ones by whom the state can be harmed.

21. And so I do not fear that the conspirators, who are now without leaders, can carry out their plans.

22. But I fear that some one may persuade you to free those leaders from prison.

23. If you decree death for these men, there will be no one who will not confess that it was done justly.

24. On the other hand, wicked citizens are not worthy of obtaining their request regarding this matter.

\section{EXERCISE FOR ORAL TRANSLATION}

1. He is afraid to return. I am afraid that he will return.

2. I am afraid that they will keep me in their town. I was afraid that they would keep me in their town.

3. I was afraid that they would not escape.

4. He was not afraid that this would not be done. I was not afraid that they would escape.

5. Who is there who is worthy of so great an honor?

6. There were some whom we did not see. This is the man whom I saw.

7. There was no one who did not fear him. He is the only man who is feared by all.

8. What is there in this city which can please you?

9. There are many who wish to depart. There is no one who wishes to remain.

10. You are worthy to be called a Roman. He is unworthy to be consul. 


\section{LESSON XV}

SUBSTANTIVE CLAUSES AFTER VERBS OF PREVENTING, DOUBTING, ETC. - REVIEW OF SUBSTANTIVE CLAUSES

572. REFERENCES :

1. Verbs of Preventing, etc.: 269-271.

2. Verbs of Doubting, etc. : 272-273.

3. Review 261-268.

\section{EXERCISE FOR WRITTEN TRANSLATION}

1. Silanus urges us to put these men to death that others may be deterred from attacking the state.

2. Caesar, on the other hand, refuses to approve of this plan and hesitates to put Roman citizens to death.

3. He does not doubt that we should inflict punishment on the conspirators, but he prefers imprisonment.

4. No one can doubt that it is to our interest to prevent other men hereafter from forming a conspiracy.

5. Yet wicked men cannot be restrained from doing this unless these suffer severe punishment.

6. Nevertheless some of the senators two days ago refused to put Roman citizens to death.

7. They were afraid, I suppose, that they would seem to have decided on something too severe.

8. Yet no one could doubt that it was to the interest of the state to employ severity.

9. For the leaders of the conspiracy could not in any other way be prevented from killing us.

10. I urge you, therefore, senators, not to hesitate to order these men to be killed.

11. For if we permit these men to escape punishment, 
we shall never be able to prevent others from making the same attempt.

12. I, for my part, shall not hesitate to employ severity in (the case of) these men.

13. Silanus did not doubt that the leaders of the conspiracy ought to be punished with death.

14. Caesar, on the other hand, tried to prevent the senators from following the advice of Silanus.

15. For he advises the senators to refuse to put Roman citizens to death.

16. He does not hesitate, however, to urge that the conspirators suffer punishment.

17. There were some (people) who did not doubt that Caesar himself was a sharer in the conspiracy.

18. They think that (it was) for that reason (that) he refused to punish the conspirators with death.

19. However, the senators could not be restrained from putting those men to death.

20. For none of them doubted that they deserved to be killed.

21. There can be no doubt that by the punishment of these men others will be prevented from forming a conspiracy.

22. Therefore we ought not to hesitate to see to it that all these conspirators pay the penalty of their crimes.

23. If we do this, we shall not have to fear hereafter that our wives and children be killed by wicked men.

24. But if we refuse to inflict punishment on these men, we shall seem to be very cruel. 


\section{EXERCISE FOR ORAL TRANSLATION}

1. We shall not prevent others from going. Translate twice, using prohibeō and dēterreō.

2. Shall we prevent others from going? Translate twice, using prohibeō and dēterreō.

3. I refuse to listen to you. I do not refuse to listen to you.

4. I did not doubt that you were at home. I did not doubt that you would be at home.

5. I did not hesitate to tell him about this.

6. There is no doubt that they know this. There is no doubt that they knew this. There is no doubt that they will learn this.

7. These men are unworthy of being sent.

8. Who is there who does not wish to go?

9. I ordered that no one' should leave the camp.

10. Thus it happened that no one was sent.

\section{LESSON XVI \\ WISHES-REVIEW OF CONDITIONS}

575. REFERENCES :

1. Wishes : 226-231. 2. Review 298-312.

3. Sequence of Tenses: 249.

576. EXERCISE FOR WRITTEN TRANSLATION

1. May we preserve forever, senators, the harmony which has been established in my consulship!

2. For if we should all defend the state bravely, no one would be able to harm it.

3. If all had realized before how great a conspiracy was being formed, we could easily have averted the danger. 
4. Would that we had not endured Catiline so long! Would that he were now dead!

5. If Lentulus thinks that the people can be incited now, he is greatly mistaken.

6. May he not find any one so wicked as to desire to destroy this city!

7. O that the city may be freed from the firebrands and weapons by which it is beset!

8. If many of the citizens were not afraid that the city would not have sufficient forces, I should order these men to be killed at once.

9. Would that the loyalty of all the citizens were as great as the patriotism of the Roman knights !

10. If the possession of liberty and the sight of the city are dear ${ }^{1}$ to you, you ought to punish these men at once.

11. May every one, therefore, contribute as much loyalty as he can to the safety of the state!

12. For if all do this, we shall easily prevent wicked men from attacking the state hereafter.

13. But if you should fail the Roman people at this time, we should all be slaughtered.

14. May we all, therefore, perform our duty and save the state!

15. If Catiline had led forth all of his followers, the city would have been freed from danger before.

16. Would that he had led forth all of the conspirators to the camp of Manlius!

17. Now if he should lead his army against Rome, we should easily protect our wives and children. 
18. Nevertheless I hope that he will not attack the city.

19. But if he were already leading his army toward the city, we should not be in danger.

20. Would that I knew what he is trying to do now!

21. For if we knew what he wished to do, we could easily check his plans.

22. O that all had known what his plans were!

23. For if all had known this, we could have prevented Catiline from escaping.

24. Now if I thought that all agreed with me, I should be willing to punish the conspirators with death.

\section{EXERCISE FOR ORAL TRANSLATION}

1. O that he would lead forth all of his followers! that he had led forth all of his followers! O that he were leading forth all of his followers!

2. May the immortal gods give you that intention!1

3. O that we may not be sent !

4. Would that we had not been sent! Would that we were not being sent!

5. If we had been sent, we should have gone. Would that we had gone!

6. If you should go to Rome, you would see him there. May we see him there!

7. What will they do if their houses are burned? May their houses not be burned!

8. I do not doubt that he is staying in Rome.

9. We cannot prevent him from leaving the city.

10. I am afraid that we cannot save the state. 


\section{LESSON XVII}

\section{CONDITIONAL CLAUSES OF COMPARISON - POTENTIAL SUBJUNCTIVE}

578. References :

1. Conditional Clauses of Comparison: 313.

2. Potential Subjunctive : 232-235. Cf. 219.

\section{EXERCISE FOR WRITTEN TRANSLATION}

1. I have performed my duty just as if I did not realize that $I$ was gaining a multitude of enemies.

2. I would gladly forget that this great danger threatens me, but one cannot thus avoid a danger.

3. If these conspirators ever drive me into exile, as if I were an enemy-of-the-state, still I shall not repent my acts.

4. For on account of my acts you have honored me as if I were (a) Scipio or (a) Pompey.

5. But the conspirators who have not yet been arrested are speaking of me as if $\mathrm{I}$ had done this not wisely, but rashly and cruelly.

6. Some one may ask me why I think that the enmity of those conspirators will be lasting.

7. You may be able to hold civil enemies in check for a short time, but you cannot win them over to the state.

8. Who, therefore, can believe that we are now free from dangers?

9. Truly we are living in the midst of dangers, just as if the forces of a foreign nation were dwelling secretly in our city.

10. But you can easily see that these same civil enemies, through lack of leaders, are no longer strong. 
11. Therefore I urge you to kill these men just as if hey were the captured leaders of an enemy's army.

12. For who would ever have spared an enemy's leaders (if) captured within our city?

13. I have spoken, I confess, as if by far the greatest danger had not already been averted from you.

14. For who can deny that for many days in succession before Catiline's departure we barely escaped destruction?

15. Then, indeed, you might have thought that we, not they, were the wicked citizens.

16. Then you might have seen us trembling ${ }^{1}$ at their threats just as if they were defending the state against us.

17. If you free these men, senators, you will be deserving of blame, as if you had let the enemy loose on us.

18. Some one may inquire why I desire death rather. than imprisonment for Lentulus and his associates.

19. I know, just as if the conspirators themselves had informed me, that their friends will try to free them.

20. Why should we hesitate to put them to death? Who can say that they are not worthy of death?

21. You cannot in any (other) way prevent such men from injuries to ${ }^{2}$ the state.

22. I would gladly have won them over to the state. Even now I would gladly spare them.

23. But these men, (if) freed, would at once attack us, just as if we were not deserving of thanks for our mildness.

580. EXERCISE FOR ORAL TRANSLATION

1. He talks as if he were a Roman citizen.

2. He talks as if he had always lived in this place.

$$
1 \text { Infinitive. 2 "of." }
$$


3. He ordered me (about) as if I were a slave.

4. The soldiers obey him as if he were a general.

5. You might have thought him the general.

6. Some one may ask why we obeyed him.

7. Who can deny that he was killed in war?

8. Who would have believed that he could command an army?

9. One would not easily find a braver commander.

10. Why should we not rejoice that we have such a commander?

\section{LESSON XVIII \\ GERUND-GERUNDIVE-SUPINES}

581. REFERENCES:

1. Gerund: 376,381 .

3. Gerundive Construction: 378-379.

2. Gerundive: $377,380,381,382$. 4. Supines : 390-393.

5. Summary of Purpose Constructions : 257, 381, 390.

582. EXERCISE FOR WRITTEN TRANSLATION

1. For many years before the Manilian law (was passed) Cicero had had almost daily practice in ${ }^{1}$ speaking in trials of private (citizens).

2. Throughout these years accusing wrongdoers had not been pleasing to him. Therefore he had devoted himself to defending the innocent.

3. And so whatever power he had, all this he employed for the purpose of defending his friends.

4. He had always been desirous of ascending through all the grades of honor and gaining the highest office.

5. His hope had not deceived him, for the people by 
intrusting office to him had shown how highly ${ }^{1}$ they considered his services.

6. During this year Manilius referred to the people a law regarding the (question of) choosing one man for the war in Asia.

7. Such an opportunity of defending a popular cause and of winning the people's good will was not to be lost.

8. On an appointed day the people had assembled to listen to speeches about the war in Asia.

9. Cicero therefore went to the forum to deliver a speech, and it was easy to see that the opportunity for speaking pleased.him.

10. Now for the first time I have come to speak from this place about a public question.

11. But (it is) not my will (which) has hitherto kept me from displaying my ability in speaking ${ }^{2}$ in behalf of your cause.

12. To me you ought to give your cause to be defended.

13. For it arouses in me so great zeal for defending (it) that moderation rather than fluency in speaking ${ }^{2}$ is to be sought for.

14. Let us now consider what has been done, what is being done, (and) what is to be done in Asia.

15. During many years and to many generals we have intrusted the subduing ${ }^{3}$ of Asia and the killing ${ }^{3}$ of Mithridates.

16. Nevertheless Mithridates lives and considers this time to be suitable for seizing all Asia.
1 Cf. 122.
2 Use the genitive.
${ }^{3}$ Cf. 382. 
17. Let us keep in mind, Romans, why we are sending a new general into Asia to crush Mithridates.

18. First, it is a question of defending your greatest revenues, for it is not to be doubted that your revenues are at stake.

19. In the second place, you who desire new provinces ought to be desirous of preserving the provinces which you already hold.

20. Finally, by killing Mithridates himself we can wipe out $^{1}$ the disgrace which we received so many years ago.

21. For at that time he arranged by letters and messengers for all Roman citizens in Asia to be killed. ${ }^{2}$

22. Wonderful to tell, he still lives and seems even to have increased his power by fighting with us.

23. Furthermore, there is now in Asia a general who is not prepared for waging war with so powerful an enemy.

24. The misfortunes of our army seem to be attributed not to the fault of Lucullus, but to the great ability of Mithridates.

\section{EXERCISE FOR ORAL TRANSLATION}

1. He has come to fight; . . . to defend us; ... to defend our city. Express by using (a) ad; (b) causā ; (c) supine.

2. We gave our city to him to be defended.

3. Opportunity was given to him of retreating. Opportunity was given to them of retreating.

4. By setting out at once he can arrive in three days.

5. Our soldiers were eager for fighting.

6. Our soldiers had daily practice in fighting. 
7. He asked our opinion about (the question of) fighting at once.

8. He asked our opinion about the plan of drawing up the line of battle.

9. This enemy is not to be feared.

10. The best thing to do is to fight at once.

\section{LESSON XIX}

\section{PASSIVE PERIPHRASTIC-OUGHT AND MUST}

584. REFERENCES :

1. Passive Periphrastic: 383-389. 2. Dative of Agent: 384, 388, 88.

3. Oportet and Necesse est : $325,2,3$.

585. EXPLANATIONS :

1. Note the various ways of saying "I ought to do this :"

(a) Id facere dēbeō. (328)

(b) Mē id facere oportet.

(c) Id faciam oportet.

(d) Id mihi faciendum est. (383)

2. Note the various ways of saying "I ought to have" done this :"

(a) Id facere dēbuī.

(b) Më id facere oportuit. $\left.{ }^{\circ}\right\}$ (326)

(c) Id facerem oportuit.

(d) Id mihi faciendum erat (fuit). (383)

3. Note the various ways of saying "I must do this : "

(a) Mē id facere necesse est.

(b) Mihi id facere necesse est.

(c) Id faciam necesse est.

(d) Id mihi faciendum est. (383)

$(325,3)$

4. Note the various ways of saying "I had to do this :"

(a) Mẽ id facere necesse erat (fuit).

(b) Mihi id facere necesse erat (fuit).

(c) Id facerem necesse erat (fuit).

(d) Id mihi faciendum erat (fuit). 


\section{EXERCISE FOR WRITTEN TRANSLATION}

1. Our ancestors had to wage many wars in behalf of our merchants.

2. What ought you to do now when so many thousand Roman citizens have been killed ? 1

3. Because their ambassadors had been haughtily addressed, your ancestors thought that Corinth ought to be destroyed.

4. Ought not we, then, ${ }^{2}$ to avenge the murder of our consul?

5. Should we not defend the name and safety of the Roman people from all its enemies?

6. The glory which our ancestors handed down to us we must defend and preserve with the greatest care.

7. The two kings who threaten all Asia must be punished.

8. We must choose a general to be placed in charge of this war, and he must go to Asia at once.

9. We must consult the interests of our allies, and our tributaries in Asia ought to be protected from these kings.

10. Our provinces also should be protected, for now our greatest revenues are at stake.

11. Therefore Asia, which surpasses all lands in the fertility of its fields and in the variety of its products, must be defended not only from disaster but also from the fear of disaster.

12. How ought our allies in Asia to feel ${ }^{3}$ when we do not aid ${ }^{1}$ them with our armies?

1 Subjunctive. Cf. 292.

2 igitur.

8 "Of what mind ought our allies to be," etc. 
13. If you wish them to be a source-of-revenue ${ }^{1}$ to you, rou must free them from the fear of the enemy.

14. Nor should you overlook (the fact) that many Roman citizens have money invested in Asia in farming your revenues.

15. Their interests you must look out for, and their fortunes should be a matter-for-consideration ${ }^{2}$ to you.

16. If you wish to preserve your revenues, the men who collect them ought to be protected by you.

17. You should therefore see to it that a general is sent to Asia who can ${ }^{3}$ protect your allies.

18. I must speak to you concerning the choosing (of) a general.

19. The man whom we shall place in charge of the war will have to protect all our tributaries.

20. He will have to defeat the two most powerful kings of Asia.

21. We ought, therefore, to send a man to this war who is (a man) of the utmost bravery and moderation.

22. If we wish to please our allies, we ought to send Pompey to them.

23. Had we done this before, we should not have had to defeat so large an army.

24. But we ought not to hesitate now to put Pompey in charge of these great affairs.

\section{EXERCISE FOR ORAL TRANSLATION}

1. Pompey ought to be sent. We ought to send Pompey. 
2. It must be decided at once. You must decide at once.

3. We ought to await him. Express in four ways.

4. We ought to have awaited him. Express in four ways.

5. We must defeat this army. Express in four ways.

6. We had to defeat that army. Express in four ways.

7. I shall have to remain. Use the passive periphrastic and conjugate in the future.

8. I had to do this. Use the passive periphrastic and conjugate in the imperfect.

9. If he were at Rome, he ought to be sent.

10. Labienus must obey Caesar. Use the periphrastic.

\section{LESSON XX}

\section{CONDITIONS IN INDIRECT DISCOURSE}

588. REFERENCES :

1. General Statement : 351 .

3. Ideal Conditions : 353.

2. Logical Conditions : 352 .

4. Unreal Conditions : 354-355.

\section{EXERCISE FOR WRITTEN TRANSLATION}

Note. Sentences 1-8 and 13-20 should each be written three times : (a) direct disçourse; (b) indirect discourse after Cicerō dīcit ...; (c) indirect discourse after Cicerō dīxit . . . .

1. If Pompey is in Asia, our allies are safe.

2. If he conquers Mithridates, he will save our allies.

3. If Lucullus had destroyed the army of the enemy, Mithridates would not have renewed the war.

4. If Pompey were in charge of the war, the allies of the king would fear us. 
5. If we should send Pompey to Asia, we should in a ;hort time defeat the king.

6. If Lucullus had remained in Asia, perhaps he would ave been able to finish the war.

7. If you recalled him from the war, you made a great mistake. ${ }^{1}$

8. If we do not defeat Mithridates at once, our revenues will be lost.

9. I believe that if Pompey were not already in Asia, he ought to be sent.

10. Do you think that your revenues can be preserved if you do not protect your allies?

11. I have often said that if there were any one else, we should not have to send Pompey.

12. Our allies say that if you had sent Pompey before, they would have been saved.

13. If we do not protect our allies from disaster, we shall not receive our revenues.

14. If Pompey is a suitable man, he ought to be sent to Asia.

15. If we had consulted the interests of our tributaries, we should have aided them.

16. If Lucullus were in command of our army now, we should not be able to defeat Mithridates.

17. Our revenues will be lost if we do not protect our province.

18. If we had chosen Pompey general before, our allies would have been protected.

1 "you erred greatly." 
19. If Mithridates should destroy the cities of our allies, we should not retain our province.

20. If we had a great number of good generals, it would not be difficult to choose.

21. I hope that if Pompey is sent, he will easily protect our tributaries.

22. Yet some men have said that if Pompey had been placed in charge of the war, he would not have been able to defeat Mithridates.

23. For they think that if Lucullus was unable to protect the province, Pompey will not save (it).

24. Still I know that if Pompey were there, he would be able to help our allies.

590. EXERCISE FOR ORAL TRANSLATION

Note. Translate each sentence three times: $(a)$ direct discourse; (b) in indirect discourse after dīcō; $(c)$ in indirect discourse after dīxī.

1. If Caesar is leading, we are safe.

2. If Caesar were leading, we should be safe.

3. If Caesar should lead, we should be safe.

4. If Caesar had led, we should have been safe.

5. If Caesar leads, we shall be safe.

6. If Caesar leads, the enemy will be conquered.

7. If Caesar had led, the enemy would have been conquered.

8. If Caesar had led, he would have been able to conquer the enemy.

9. If the general had found this out, he ought to have sent aid.

10. If I had found this out, I might have gone. 


\section{LESSON XXI}

\section{caUsal claUses}

591. REFERENCES :

1. Cum Causal : 292.

2. Relative Causal Clauses : 293.

3. Quod, Quia, Quoniam, Quand̄̄: 294-297.

4. Causal Clauses with Verbs of Emotion : 296.

\section{EXERCISE FOR WRITTEN TRANSLATION}

1. Pompey ought to be chosen as your general because he possesses a knowledge of war(fare), ability, prestige, (and) good luck.

2. Since he has brought-to-a-successful-conclusion so many wars, no one can doubt that he possesses a knowledge of war(fare).

3. For he has often celebrated-a-triumph in-accordance-with ${ }^{1}$ a decree of the senate because (as the senators said) he had freed us from peril.

4. Moreover, since so many nations are witnesses of this man's ability, no one can deny that he possesses that quality. ${ }^{2}$

5. The whole of Italy was once grieving because it was oppressed by a great and serious war.

6. But after his arrival this same Italy was soon rejoicing because it had been freed from danger.

7. You especially, fellow-citizens, since you have been freed from the pirates, ought to recognize his ability.

8. Because this war which we waged with the pirates was so disgraceful to us, I ought to speak further about it.

9. And since (as all know) the pirates have been 
driven from the sea, I may now speak freely about that disgrace.

10. A few months ago our provinces and allies were complaining that we were not defending them.

11. We could not defend them, because even our armies were afraid to set sail on account of the pirates.

12. Under these circumstances Gabinius persuaded you to choose Pompey as general, because (as he said) you were being cut off from your grain supply.

13. Now since you are praising him for having waged 1 this war so well, you ought likewise to praise him for having finished it so quickly.

14. He did all this so quickly because he was eager for victory, not for gold.

15. Since we must now choose a general for the war in Asia, ${ }^{2}$ let us choose a man distinguished for his honor and ability.

16. Let us therefore choose Pompey, since he alone is considered such (a man) by your allies.

17. For our allies have often complained that our generals were distinguished not for ability, but for greed and cruelty.

18. Can you doubt that this is true when ${ }^{3}$ you know how disgracefully our generals have acted even in Italy?

19. These generals cannot control their soldiers because they do not control themselves.

20. Since this is so, why should we hesitate to send

1 "for having waged," = "because he has waged."

2 " in Asia" = Asiāticus, -a, -um.

3 "when" is sometimes causal in sense. 
Pompey to this war when our allies ask for him and our znemies fear him.

21. Our allies ask for him because (as they say) he does not harass (them), but defends them.

22. Our enemies fear him because he never turns aside from victory to obtain booty.

23. Our ancestors, during a former war, rejoiced because they had one commander, Scipio, worthy of the highest command.

24. This being the case, are we going to deny the highest command to Pompey because (as some say) the precedents of our ancestors hinder us?

\section{EXERCISE FOR ORAL TRANSLATION}

1. Under these circumstances, why do we hesitate?

2. We have chosen Pompey again because he finished the other war so quickly.

3. The citizens praised him "because he had freed them from fear."

4. Since it is summer the pirates are on the sea.

5. All the citizens rejoiced because they had been freed from fear.

6. He finished this war so quickly because he thought of nothing else.

7. We shall not prevent him from going away. Translate twice, using impediō and prohibeō.

8. We do not doubt that he will go away.

9. We are not afraid that he will go away; he is not afraid to go away.

10. We shall not make him go away. We made him go away. 


\section{LESSON XXII CONCESSIVE CLAUSES}

594. REFERENCES :

1. Concessive Conjunctions : 314. 5. Quamvis : 319.

2. Cum Concessive : 315 .

6. Licet: 320 .

3. Concessive Relative : 316 .

7. Ut and Nē : 321 .

4. Quamquam : $317-318$.

8. Etsī, Etiamsī, Tametsī : 322.

595. EXERCISE FOR WRITTEN TRANSLATION

1. Our generals, though they are sent as a protection to our provinces, are more frequently a plague.

2.' They devote themselves to laying waste the lands of our allies, even though we send them to wage war with our enemies.

3. This being the case, they accomplish nothing with their armies, however skillful they may be in waging war.

4. Granted that a few have devoted themselves to waging war, nevertheless they have not defeated our enemies.

5. Will you, refuse to grant to Pompey the command of the war in Asia in-spite-of-the-fact-that he alone is worthy (of it)?

6. . Even though it would be contrary to ancient precedent to do this, yet it would be better to yield to necessity than to precedent at this time.

7. Though . Pompey ought to be chosen because of his ability and self-restraint, I shall also speak of his prestige.

8. Though he has gone to Asia to wage a different war, his mere ${ }^{1}$ arrival and prestige have checked Mithridates. 
9. A general has need of good-luck also, however nuch he may possess ability and knowledge of war.

10. Though we cannot say that good-luck will be lastng for any one, we know that Pompey has up to this time oossessed that quality. ${ }^{1}$

11. Finally, even though our enemies fear him, yet (when) defeated they willingly surrender to him because of his justice.

12. But they would prefer to flee and fight again rather than surrender to our other generals, even though they should be defeated in many battles.

13. Although Mithridates has often been defeated by our generals, he still reigns and is threatening our provinces.

14. Though it is a splendide (thing) to conquer a powerful king, it is disgraceful to conquer the same king so many times to-no-purpose.

15. In-spite-of-the-fact-that we have received so great an injury from that king, he still reigns.

16. Even if Ariobarzanes had not been our ally, yet we ought not to have permitted Mithridates to seize his kingdom.

17. Our ancestors, though they themselves were provoked by no wrong, used to wage war on-behalf-of their allies.

18. We, however, though our greatest revenues are at stake, are hesitating to prosecute this war with the greatest zeal.

1 res.

2 pulcher. 
19. Granted that no attack has as yet been made on our tributaries, yet by the mere ${ }^{1}$ fear of an attack our revenues are being diminished.

20. Mithridates, though he had been forced by Lucullus to retreat as a suppliant to other nations, again collected an army.

21. And our army, though it had fought ${ }^{2}$ successful battles, refused to advance farther into the enemy's lands.

22. Meanwhile Mithridates, though he had a short time before been defeated, returned and put our army to flight.

23. Although I know how this happened, I prefer to be silent about our calamity.

24. Even if our prestige were not at stake, yet the war ought not to be neglected.

\section{EXERCISE FOR ORAL TRANSLATION}

1. Though many generals have defeated him, no one has captured him.

2. Mithridates, though he has been conquered, still reigns.

3. Even though he should be conquered, he would escape.

4. Granted that his cities have been captured, yet he has an army.

5. However much you may beg me, I shall not go.

6. Though he may make peace with us, the peace will not be lasting.

7. We consider him a great general, though he has often been defeated. 
8. O that he would not wage war with us !

9. O that he were not our enemy!

10. Would that he had made peace with us!

\section{LESSON XXIII}

temporal ClaUses: CUM, POSTQUAM, atc.

597. REFERENCES :

1. Cum Temporal : 277-282.

2. Postquam, etc.: 283-284.

\section{EXERCISE FOR WRITTEN TRANSLATION}

1. When we are choosing a general to put in charge of this war with the king, we must consider Pompey as a suitable man.

2. For when he was waging war against the pirates, he showed that he was a man of unusual ability.

3. As soon as he had equipped his fleet, he set out for Cilicia.

4. After he had defeated the pirates there, he freed the entire sea of our enemies.

5. At the time when Gabinius was proposing the law by which Pompey was put in charge of the naval war, Hortensius opposed that law.

6. And now when we are trying to put Pompey in command of the war with the king, this same man disagrees.

7. But when Pompey had freed us from fear of the pirates, we could see that we had made no mistake.

8. So when we send him to protect our allies in Asia, these men will agree with us. 
9. After our ancestors had defeated the Carthaginians, our fleets were feared by all foreign nations.

10. But when several of our ambassadors had fallen ${ }^{1}$ into the power of the pirates and the sea was full of their ships, we lost our prestige.

11. Furthermore, whenever Roman citizens had been captured by the pirates, we had to ransom them.

12. But when Pompey had freed the sea of pirates, our former glory and prestige were restored.

13. At the time when our quaestors and praetors were being captured by the pirates, we surely did not seem to hold the supremacy of the earth.

14. But after the pirates had been defeated by Pompey, no one could deny that we had avenged our wrongs.

15. For when the sea had been freed of pirates, our merchants and citizens were safe.

16. But as soon as he had finished this war, another (war) sprang up in Asia.

17. Therefore when we are considering whom to put in charge of this war, Pompey must not be overlooked.

18. For when our general goes to Asia, he will find a very serious war going ${ }^{2}$ on there.

19. At the time when we had chosen Pompey for the naval war, many thought that he could not manage it.

20. Now likewise, when this law has been proposed, Catulus and Hortensius say that everything ought not to be assigned to one man. 
21. When they said this before, they erred greatly and low they are making the same error.

22. For heretofore whenever Pornpey undertook ${ }^{1}$ anything, he carried it out with the greatest success.

23. So when we send him to aid our allies in this war, he will be able to defend them.

24. Then foreign nations will fear the power of the Roman people just as they did at the time when our ancestors lived.

\section{EXERCISE FOR ORAL TRANSLATION}

1. When I am in Rome, I do as the Romans (do).

2. When Caesar was in Gaul, he was informed of this conspiracy.

3. When Caesar arrived at the river, the enemy were fleeing.

4. At the time when I was writing to you, I was in Italy.

5. When he comes to the city, I shall send him to you.

6. As soon as he had said this, he departed from the senate.

7. After Catiline had left the city, Cicero summoned the senators together.

8. At the time when many had lost their fortunes, we were safe.

9. Whenever he saw any one, he ran. Whenever any one comes, he will run.

10. I shall tell you this after he goes away. 


\section{LESSON XXIV}

\section{DUM CLAUSES - PRIUSQUAM AND ANTEQUAM}

600. ReFERENCES :

1. Dum, etc., while, so long as: 285.

2. Dum, etc., while, within the time that: 286 .

3. Dum, etc., until : 288.

4. Proviso : 290.

5. Priusquam and Antequam: 289.

601. EXERCISE FOR WRITTEN TRANSLATION

1. Before I finish talking, I must speak of the authority and opinion of Quintus Catulus.

2. While he was speaking on this law a few days ago, he asked this (question).

3. Whom will you appoint in place of Pompey if anything happens to him before he finishes this war?

4. But provided that Pompey does not perish, we shall not have to choose any one else.

5. Before Pompey was placed in charge of the war with the pirates, ${ }^{1}$ Catulus and Hortensius asked this same (question).

6. Did they wish us then to wait until Rome should be captured by the pirates?

7. And ought we now also to delay until our revenues are all lost and our allies murdered?

8. Provided only that the rest of the citizens agree with me, I think that the authority of Catulus is to be considered of little importance.

9. For while the immortal gods permit, the state ought

1 " war with the pirates" = bellum nāvāle. 
to enjoy the life and services of this (the) greatest (of) general(s).

10. In accordance with a decree of the senate, Pompey was made consul before he was permitted by the laws to hold any other office.

11. While he was in Africa he acted with unusual integrity, dignity, (and) ability..

12. He was then put in charge of the war with the pirates ${ }^{1}$ before they should destroy our power altogether.

13. While we are speaking of the choice of a general for this war, we must remember what Pompey has done up to this time.

14. When he had been put in charge of the naval war, he did not delay until all of our ships were destroyed.

15. But he proceeded at once to the hiding places of the pirates before they should be able to prepare for war.

16. Then while they were still ignorant of his movements, ${ }^{2}$ he arrived in Cilicia.

17. And so, before fifty days had elapsed, he defeated all the pirates.

18. If only he acts with the same dispatch in this war, we shall have nothing to fear.

19. Nevertheless, until he is appointed general for this war with the king, our allies will be in great danger and fear.

20. Yet provided the authority of Catulus and Hortensius does not prevail with ${ }^{3}$ you, Pompey will be sent to Asia.

1 " war with the pirates" bellum nāvāle.

2 "ignorant (of) what he was doing."

3 apud. 
21. But he must be sent before all Asia falls ${ }^{1}$ into the power of Mithridates.

22. For while we are delaying here that king is increasing his forces and is threatening our allies.

23. Before Lucullus withdrew from the war he defeated Mithridates and celebrated a triumph (for a victory won) over him.

24. Yet before he had reached Rome the king had recovered from these disasters and had returned into his ancestral kingdom.

\section{EXERCISE FOR ORAL TRANSLATION}

1. While we were delaying in this town a messenger arrived.

2. While we were delaying in this town we were in great danger.

3. Caesar waited for the rest of the ships to assemble.

4. The enemy held the town until our troops forced them to withdraw.

5. Let them hate (me), provided they fear (me).

6. If only he does not remain in the city, I am not afraid.

7. Caesar captured the bridge before the rest of the army arrived.

8. Caesar captured the bridge before the enemy could cross.

9. At the time when I was doing this I was in Rome.

10. After he had reached the city he sent a message to me.

1 "falls" = "comes," 


\section{LESSON XXV}

\section{PARTICIPLES}

603. REFERENCES :

1. Formation and Use : 359-361.

3. Participles as Adjectives : 366.

2. Tenses of Participles : 360-365. 4. Participles as Nouns : 367-368. Cf. $511 ; 2$.

5. Participles as Clauses : 375.

\section{EXERCISE FOR WRITTEN TRANSLATION}

\section{The First War with Mithridates}

1. More than twenty years ago Mithridates received from his father a kingdom (which was) situated between Armenia and Paphlagonia.

2. After getting possession of Armenia, he soon seized other neighboring kingdoms.

3. The Romans being alarmed by these movements ${ }^{1}$ ordered him to withdraw at once into his own territory.

4. But (as they were) not (well) enough prepared for waging war, they could not make him do their bidding.

5. At this very time Sulla set out for Rome, being recalled by civil disturbances.

6. Mithridates, therefore, persuaded many cities to use $^{2}$ this opportunity, and to free all Asia from the sway of the Romans.

.7. Since these (people) were influenced ${ }^{2}$ by the great exploits of Mithridates, they followed ${ }^{2}$ his advice and killed more than eighty thousand Italians.

8. For Mithridates had ordered them to kill all the Italians in all Asia, and not to spare the fugitives.

9. And so the armed soldiers of the Asiatic kings 
attacked $^{1}$ the unarmed Italians and killed them (while they were) trying $^{1}$ to escape.

10. Since Mithridates had now got possession ${ }^{1}$ of almost all Asia, he decided to advance into Greece.

11. For he believed that many states of Greece, (because they had been) harassed by the greed of the Romans, would surrender willingly.

12. He was not mistaken, for the citizens of many towns, upon catching sight of his army, sent forward envoys to ask for peace.

13. In many parts of Greece the citizens with tears ${ }^{2}$ begged the leaders of the Asiatic army to accept their surrender. ${ }^{3}$

14. Finally Athens and many other Greek cities (which had been) freed so many years before from the fear of an Asiatic king were captured by Mithridates.

15. Then Sulla, fearing that other parts of the Roman empire would be captured, set out for Greece.

16. After getting possession of the inland cities (which had been) captured, he besieged and captured Athens.

17. At this point Mithridates, thinking ${ }^{4}$ that he had already delayed too long, decided to fight as soon as possible.

18. After having tried in vain to lead the Romans into an unfavorable position, he at last began battle in a place chosen by them.

19. But Sulla, fearing that they would attack his army

1 Express by a participle.

2 "with tears" = "weeping."

8 " accept their surrender" = " receive them into surrender."

4 Use arbitror. 
from the rear, had protected that part by ditches, and had built a rampart in front.

20. When the enemy were advancing-to-the-attack, he kept his forces drawn up inside the rampart.

21. From this rampart they hurled a shower ${ }^{1}$ of stones and weapons on the advancing enemy.

22. The first line (when) driven back, threw into confusion those (who were) coming (up) from the rear.

23. The enemy (who had been) thus thrown into disorder were then put to flight by Sulla's cavalry.

24. Finally both the cavalry and the infantry pursued the enemy (while they were) fleeing and killed a great number of them.

605. EXERCISE FOR ORAL TRANSLATION

1. We attacked them (while they were) setting out from camp.

2. We attacked those who had set out from camp.

3. We attacked the fugitives.

4. The armed (soldiers) attacked the fleeing citizens.

5. Our cavalry, pursuing the enemy, killed many.

6. Our cavalry pursued the enemy and killed many.

7. Our cavalry pursued the conquered.

8. The lieutenant after exhorting his soldiers began the battle.

9. These men, influenced by the king's exploits, did his bidding.

10. This army, though put to flight, will fight again. This army, since it has been put to flight, will not fight again.

1 multitūđō. 


\section{LESSON XXVI}

\section{ABLATIVE ABSOLUTE}

606. REFERENCES :

1. The Ablative Absolute: 369 .

2. Ablative Absolute with the Participle Omitted: 370.

3. Ablative Absolute equivalent to a Clause : 371 .

4. When to use the Ablative Absolute : 372-373.

5. When to avoid the Ablative Absolute: 374 .

\section{EXERCISE FOR WRITTEN TRANSLATION}

1. Sulla, after putting the king's army to flight, returned to Athens to winter, since the summer was now almost spent.

2. Mithridates, having collected another army during that winter, set out for Greece as summer was coming on.

3 . In the early summer a battle was fought, ${ }^{1}$ in the absence of the king himself, under the leadership of Archelaus.

4. At the first attack the Roman line began to fall back, so fiercely were the horsemen of the enemy pressing on.

5. But since Sulla himself was present and encouraging the soldiers, the attack was soon checked.

6. When at last the cavalry of the enemy had been put to flight, it was an easy (task) to defeat the infantry.

7. Sulla believed that if a very great part of this army was cut down, another would not be sent against him.

8. Therefore, when the army had been put to flight, 
he ordered his cavalry to pursue, and not to spare any one at all.

9. Since at last an opportunity was offered of pacifying all Greece, Sulla devoted himself to this task for the rest of the summer.

10. After having finished this, during the following winter he built and equipped a large fleet for the war in Asia.

11. Meanwhile many states of Asia had learned that if Mithridates were ruling, his rule would be more cruel than the Romans'.

12. Therefore they expelled the kings friendly, to Mithridates and again came into the control of the Romans.

13. After deciding on terms of peace, Sulla set out for Rome, leaving Murena with two legions in Asia.

14. After Murena had delayed in Asia for several years, Sulla recalled him to Rome.

15. Though Asia had enjoyed peace for several years, a new war suddenly broke out.

16. For no peace could be lasting in Asia while Mithridates was alive.

17. For in the absence of a Roman army he could not be restrained from attacking Rome's allies.

18. Accordingly, the Roman senate, after collecting an army and equipping a fleet, intrusted the war to Lucullus.

19. The Romans were afraid that, if a few cities were captured by the king, more would surrender through fear.

20. When scarcely six months had passed, Lucullus had freed the cities of our allies from siege. 
21. This same general destroyed the enemy's fleet and opened up Pontus by defeating them in many battles.

22. Then he captured the towns in which the king's dwellings were, and drove the king himself into exile.

23. Furthermore, all this ${ }^{1}$ was done with our allies safe and our revenues unharmed.

24. But Lucullus allowed the defeated king to escape, and he, ${ }^{2}$ after collecting new forces, defeated our (once) victorious army.

\section{EXERCISE FOR ORAL TRANSLATION}

1. They accused me in my absence. They did this in my absence.

2. They have elected him without his consent. They did this without his consent.

3. He says that they did this in his absence.

4. We have done this under his leadership.

5. We could not take the town, though (but) few were defending (it).

6 a. Though he had got possession ${ }^{3}$ of the town, he spared the citizens.

b. He got possession ${ }^{3}$ of the town, but spared the citizens.

7. We could not take the town since so great a multitude was defending it.

8. He has decided to collect a new army and try again.

9. He set out as summer was coming on ; ... when summer had begun.

10. He returned when the winter was almost spent.

1 " all this" = "all these (things)."

2 Use the relative.

3 Express twice, using capiō and potior. 


\section{SPECIAL VOCABULARIES}

\section{PART II}

\section{LESSON I}

accūsō, -āre, -āvī, -ātum, accuse, charge. Cf. 121.

acerbus, -a, -um, bitter, harsh, severe.

adhūc, (adv.), up to this time, heretofore, hitherto, still.

colligō, -ere, -lēgī, -lēctum, bring together, collect.

committō, -ere, -mīsī, -missum, commit.

cōnstituō, -ere, -stituī, -stitūtum, place, station, select, mark out. dēcernō, -ere, -crēvī, -crētum, decree, pass a decree. exitium, -i, n., \}destruction, perniciēs, -ēì, f., \}ruin.

gravis, -e, heavy, severe. ignōrō, -āre, -āvī, -ātum, not know, be ignorant. nesciō, -īre, -īvī or -ī̄, -ītum, not know, be ignorant. improbus, -a, -um, wicked. incendium, $-\overline{1}, \mathrm{n}$., burning, fire. iste, -a, -ud, that (of yours). Cf. 31.

item, (adv.), likewise, also. nihil, nothing; not at all. ōrātiō, -ōnis, f., speech; ōrātiōnem

habeō, deliver a speech. scelus, sceleris, n., crime. scientia, -ae, $f$., knowledge. senātus, -ūs, m., senate; senātūs cōnsultum, a decree of the senate.

uter, utra, utrum, which (of $t w s)$. Cf. 45.

\section{LESSON II}

āmentia, -ae, f., madness, folly, want of reason. audācia, -ae, f., boldness, daring. cōgitō, -āre, -āvī, -ātum, think, plan, plot.

cōnātus, -ūs, m., attempt, effort. coniūrātus, $-\overline{1}, \mathrm{~m}$., conspirator. cōnscius, -a, -um, conscious, aware. Cf. 113-114.

èius modi, of that sort, such. Cf. 102.

enim, postpositive particle, for. Cf. 412 .

ergā, prep. with acc. case, toward, for. Cf. 112.

in, prep. with acc. case, toward, for. Cf. 112.

insidiae, -ārum, f. pl., ambuscade, treachery, plot, stratagem.

mē commoveō, move (with reflex.), make a move.

memor, -oris, mindful, remembering. Cf. 113-114.

moveō, -ēre, mōvī, mōtum, move, actuate, influence.

oblitus, -a, -um, forgetful, for- 
getting, unmindful, regardless. Cf. 113-114.

ödi, (ōdisse), ōsūrus, hate, detest. Cf. 209-210.

odium, -ī, n., hate, hatred; in odiō alicuĩ sum, I am hated by some one.

patrēs cōnscrīptī, conscript fathers, senators.

reprimō, -ere, -pressĩ, -pressum, restrain, check, hold in' check. salūs, salūtis, f., safety, welfare. socius, -ī, m., sharer, associate, ally, accomplice. Cf. 113-114. vigilō, -āre, -āvī, -ātụm, be awake, watch, watch for (ad -).

\section{LESSON III}

admoneō, -ēre, -uī, -itu'm, remind, advise, warn. Cf. 117.

causa, -ae, f., cause, case.

comprimō, -ere, -pressī, -pressum, suppress, restrain, check.

damnō, -āre, -āvī, -ātum, condemn, convict. Cf. 121.

interest, -esse, -fuit \} it is to the inrēfert,-ferre, -tulit terest, it is of importance, it is of advantage, it concerns. Cf. 124.

meminī, (-isse), -, remember. Cf. 209-210.

metuō, -ere, metuī, - fear, be afraid. Cf. 266-268.

miseret, miserēre, miseruit, pity. Cf. 118-119.

oblīvīscor, oblīvīscī, oblītus sum, forget. Cf. 116.

operae pretium est, ] it is worth tantī est, while. $\mathrm{Cf}$. 122.

paenitet, paenitēre, paenituit, repent, regret, be sorry for. Cf. 118-119.

piget, pigēre, piguit, tire, irk, pain. Cf. 118-119.

privātus, -a, -um, private, personal. pudet, pudēre, puduit, shame.

Cf. 118-119.

recordor, -ārī, -ātus sum, recall. Cf. 116, 4 .

ruina, -ae, f., overthrow, disast r, ruin.

semper, (adv.), always.

senātor, -ōris, m., senator.

taedet, taedēre, -, disgusts, wearies. Cf. 118-119.

turpitūdō, -dinis, f., disgrace, baseness, dishonor.

vitium, $-\overline{\mathrm{i}}, \mathrm{n} .$, fault, vice.

\section{LESSON IV}

anteā, (adv.), before.

comes, comitis, m., companion, follower.

cōnsilium, -ī, n., plan, scheme.

cōnsuēscō, -ere, -suēvī, -suētum, become accustomed. Cf. 209210.

dēleō, -ēre, -ēvī, -ētum, destroy, wipe out.

dēsistō, -ere, -stitī, - cease, stop, desist.

difficilis, -e, difficult, hard.

èiciō, -ere, ēiēcī, ēiectum, cast out, drive out, expel.

exsilium, -ī, n., exile.

līberō, -āre, -āvī, -ātum, free, set free. Cf. 149.

licet, licēre, licuit, it is permitted, may. Cf. 325,3 .

mālō, mālle, māluī, —, prefer, be more willing. 
necesse est, it is necessary, must. | cōnfïrmō, -āre, -āvī, -ātum, make Cf. 325,3 .

nōlō, nōlle, nōluī, -, be unwilling, not wish.

oportet, oportēre, oportuit, it is fitting, ought. Cf. 325, 2. patefaciō, -ere, -fēcī, -factum,

lay bare, lay open, expose. patria, -ae, f., native land, fatherland.

placet, placēre, placuit, it pleases, decide. Cf. $80,325,1$.

quidem, postpositive adv., certainly, surely, even. sinō, -ere, sīvī, situm, allow, permit. Cf. 332 . soleō, -ēre, solitus sum, be accustomed. Cf. 329. spoliō, -āre, -āvī, -ātum, strip, rob, deprive, despoil, plunder. Cf. 149. vetō, -āre, vetūi, vetitum, forbid. Cf. 332.

vidētur, vidērī, vīsum est, it seems best. Cf. $325,1$.

\section{LESSON V}

arbitror, -ārī, -ātus sum, think, judge, consider.

augeō, -ēre, auxī, auctum, increase, enlarge; transitive verb. For the intransitive the passive must be used. Thus, augētur $=$ crēscit.

cotĩdiē, every day, daily; used of an act repeated every day; in diēs, every day, daily; used of something which changes from day to day.

crēscō, -ēre, crēvī, crētum, increase, grow, become larger.

firm; assert; declare.

crēdō, -ere, crēdidī, crēditum, believe, trust, intrust. Cf. 80 . cunctus, -a, -um, whole, entire, all. Cf. "all" in the general vocabulary.

dēsinō, -ere, -sīvī, -situm, leave off, cease, desist, stop.

expōnō, -ere, -posuī, -positum, set forth, explain.

exsul, exsulis, m., exile, a person banished.

fateor, -ērī, fassus sum, confess, admit.

iūdicō, -āre, -āvī, -ātum, judge, decide.

laetor, -ārī, -ātus sum, rejoice, be glad.

mors, mortis, f., death; morte multō (-āre, -āvī, -ātum), punish with death.

negō, -āre, -āvī, -ātum, say no, say . . not, deny, refuse. Cf. 335.

perditus, -a, -um, lost, desperate, wicked; as a noun, a desperate man.

petō, -ere, -īvī, -ītum, seek, ask, attack.

quā dē causā or quā dē rē, for this reason, therefore.

sentiō, -īre, sēnsī, sēnsum, realize, feel, understand, think.

surgō, -ere, surrēxī, surrēctum, rise up, arise.

vita, -ae, f., life. Commonly used in the singular only, even where the English uses the plural. The plural usually means "biographies." 


\section{LESSON VI}

arcessō, -ere, -īvī, -ītum, summon, send for.

cōnficiō, -ere, -fēcī, -fectum, carry out, complete.

contemnō, -ere, -tempsī, -temptum, despise, disdain.

deinde, (adv.), then, next.

dēnique, (adv.), finally, in the last place.

dēspērātus, -a, -um, desperate. doleō, -ēre, -ūi, -, grieve, deplore. effugiō, -ere, -fūgī, -fugitum, flee away, escape.

Gallicus, -a, -um, Gallic, of the Gauls. Cf. 98.

inclūdō, -ere, -clūsī, -clūsum, shut in, inclose.

inquam, I say. Always with direct quotations and never first. Cf. $412,3$.

inquit, he says, he said. Always with direct quotations and never first. Cf. 412, 3.

intrā, prep. with acc. case, within, inside of.

is quī . .., a man who ...

Mānliānus, -a, -um, Manlian, of Manlius. Cf. 98 .

omnēs, as a noun, all, all people, every one; omnia, all things, everything. Cf. 3 .

plēbs, plēbis, f., the common people, the plebeians.

plürimum valêre or posse, to be the most powerful or very powerful. Cf. 66.

porta, -ae, f., gate.

probō, -āre, -āvī, -ātum, approve, prove. profectō, (adv.), surely, certainly, I am sure.

quamquam, conj., although. taceō, -ēe, tacuī, tacitum, be silent.

\section{LESSON VII}

accipiō, -ēre, -cēpī, -ceptum, receive welcome.

aliquis, -qua, -quid (-quod), some, some one, some thing, any, any- . thing, any one. Cf. 47.

quis, qua, quid (quod), replaces aliquis after sī, nisi, nè, and num. Cf. 48.

āmittō, -ere, -mīsī, -missum, lose. dīligēns, -gentis, careful; dîligenter, carefully.

equidem, (adv.), certainly, I for my part.

errō, -āre, -āvī, -ātum, go astray, wander, be mistaken, make a mistake.

etiam, even; etiam nunc, even now, still; etiam tunc, even then, still.

extrā, prep. with acc. case, outside.

gaudium, -ī, n., joy.

inlūstrō (illūstrō), -āre, -āvī, -ātum, bring to light, reveal.

mẽ cōnferō, -ferre, -tulī, -lātum, betake one's self, go. Reflexive verb.

moenia, -ium, n. pl., walls, walled city, city.

mūtō, -āre, -āvī, -ātum, change.

nisi, unless, except, if not.

pertimēscō, -ere, -timuī, -, become thoroughly frightened, take fright. 
queror, querī, questus sum, complain.

scelerātus, -ī, m., criminal, scoundrel.

sciō, -īre, scīvī or sciī, scītum, know. sententia, -ae, f., opinion, intention, advice.

sin, but if.

timidus, -a, -um, timid.

tūtus, -a, -um, safe.

vehementer, (adv.), earnestly, strongly, very much, greatly.

\section{LESSON VIII}

adsequor, -sequī, -secūtus sum, cōnsequor, -sequĩ, -secūtus sum,

aes, aeris, n., copper, money; aes aliēnum, aeris aliēnī, n., debt, some one else's money. audiō, -īre, -īvī, -ītum, hear, listen to.

coerceō, -ēre, -uĩ, -itum, restrain, control.

corcēdō, -ere, -cessī, -cessum, yield, surrender.

dēficiō, -ere, -fēcī; -fectum, fail; desert, revolt.

dēprehendō, -ere, -hendī, -hēnsum,

catch, detect, discover.

gladiātor, -ōris, m., gladiator.

honestus, -a, -um, honorable; honestē, adv., honorably.

imperium, $-\overline{1}, \mathrm{n} .$,
power,
potestās, -tātis,
f., power, $\left\{\begin{array}{l}\text { imperium is } \\ \text { used for mili- } \\ \text { tary power, } \\ \text { potestās usu- } \\ \text { ally for might } \\ \text { or civil au- } \\ \text { thority. }\end{array}\right.$

obstō, -āre, -stitī, - , stand in the way, oppose, thwart. Cf. 83. quā ratiōne, quō modō, quem ad modum, how.

rērum potior (-īrī, -ītus sum), become master of the situation, get control of affairs. Cf. 166. vīvō, -ere, vīxī, vīctum, live.

\section{LESSON IX}

cōnsīderō, -āre, -āvī, -ātum, consider.

crūdēlis, -e, cruel; crūdēliter (adv.), cruelly.

dïligēns, -gentis, careful, diligent, watchful; diligenter, adv., carefully.

discessus, -ūs, m., departure.

glöria, -ae, f., glory, fame, renown. incertus, -a, -um, uncertain, doubtful.

iūstitia, -ae, f., justice.

lēnitās, -tātis, f., leniency, mildness.

levō, -āre, -āvī, -ātum, relieve. alleviate.

locuplēs, -plētis, rich, wealthy; locuplētēs, -ium, m. pl., rich men.

mereō, -ēre, -uī, -itum, or mereor, -ērī, -itus sum, deserve.

miser, misera, miserum, poor, unfortunate.

nimius, $-\mathrm{a},-\mathrm{um}$, too much, too great, excessive; nimium, $-\overline{\mathbf{1}}$, n., as noun, too much, with partitive genitive.

nōminō, -āre, -āvī, -ātum, call, name.

possessiō, -ōnis, f., possession. 
potius, (adv)., rather.

quondam, adv., once, formerly. superō, -āre, -āvī, -ātum, excel, sur-

pass, prevail, overcome, conquer. supplicium, -ī, n., punishment; suppliciō adficiō (-ere, -fēcī, -fectum), punish, with acc.; supplicium dẽ aliquō sūmō (-ere, sūmpsī, sūmptum), inflict punishment on any one.

tabulae novae, tabulārum novārum, f. pl., new records, new accounts, cancellation of debts. tālis, -e, such.

\section{LESSON $X$}

$\left.\begin{array}{l}\text { accommodātus, -a, -um, } \\ \text { aptus, -a, -um, }\end{array}\right\}$ suited.

aspectus, -ūs, m., sight.

cōnsulō, -ere, cōnsuluĩ, cōnsultum, with acc., consult, ask advice of; with dat., look out for the interests of, provide for. Cf. 80.

contrōversia, -ae, f., dispute, quarrel.

dēlectō, -āre, -āvī, -ātum, please, delight. With acc. Cf. 81 .

placeō, -ēre, -uī, -itum, please.

With dat. Cf. 80.

ëripiō, -ere, ēripuī, ēreptum, seize, take away, rescue. gëns, gentis, f., race, nation. ignnōscō, -ere, ìgnōvī, ìgnōtum, pardon. Cf. 80.

immineō, -ère, -, -, overhang, threaten. Cf. 80.

indicium, $-\overline{1}, \mathrm{n}$. , evidence. iniciō, -ere, -iēcī, -iectum, throw into, inspire, arouse, awake (an emotion). labor, -ōris, m., effort, endeavor. metus, -ūs, m., fear, dread. mox, adv., soon, presently. oculus, $-\overline{1}, \mathrm{~m}$. , eye.

opus, indecl. noun, need. Cf. 155. parcō, -ere, pepercī, parsum, spare.

Cf. 80.

praebeō, -ēre, -uī, -itum, furnish, afford.

praescrībō, -ere, -scrīpsī, -scrīptum, prescribe, instruct.

rêgnō, -āre, -āvì, -ātum, rule, reign, be king.

serviō, -īre, -īvī, -ìtum, serve, be slave to. Cf. 80 .

tum dëmum, then at last.

\section{LESSON XI}

carcer, carceris, m., prison.

cēnseō, -ēre, -uĩ, cēnsum, resolve, determine.

cōnfiteor, -ērī, -fessus sum, confess.

cūstōdia, -ae, f., custody, guard, imprisonment.

dĩ immortālēs, deōrum immortālium, m. pl., the immortal gods.

grātia, -ae, f., favor, influence, thanks, gratitude; grātiam habeō, have gratitude, be thankful; grātiăs agō, give thanks, thank; grātiam referō (-ferre, rettulī, relātum), make return, requite.

intrōdūcō, -ere, -dūxī, -ductum, lead in, bring in.

legō, -ere, lēgī, lēctum, read.

magistrātus, -ūs, m., magistrate, officer; magistracy, office.

mẽ abdicō, -āre, -āvī, -ātum, 
resign. Reflexive verb with |faciō, -ere, fēcī, | make, bring it abl. case. Cf. 149. pōscō, -ere, popōscī, 一, demand. posthāc, adv., hereafter, in the future.

prīncipiō, (adv.), in the first place.

Frequently in combination with deinde, then, next, and dēnique, finally.

prō, prep. with abl. case, in behalf of, for; in place of; in return for; in comparison with; before, in front of.

prōferō, -ferre, -tulī, -lātum, bring forth.

Quīīiēs, -ium, m. pl., fellowcitizens.

rēs, reī, f., thing, affair, matter, case.

supplicātiō, -ōnis, f., thanksgiving. vërum, -i, n., truth.

\section{LESSON XII}

accēdit, accēdere, | added (to this) accessit, additur, addī, additum est, is the fact, circumstance. Cf. 264.

accidit, accidere, accidit, it happens. Cf. 264.

administrō, -āre, -āvī, -ātum, manage, conduct, carry on.

āmēns, -entis, mad, foolish.

contingit, contingere, contigit, it

happens; commonly of fortunate happenings and frequently translated " have the good fortune to - -" Cf. 264.

èvenit, ēvenĩre, ēvēnit, the outcome is. Cf. 264.

factum, efficiō, -ere, -fēcī,-fectum, 264.

ita, sic, tam, so, in such a way, in such a manner. Tam is regularly used with adjectives and adverbs; sic and ita are commonly used with verbs, ita referring to what precedes, sic to what follows.

lateō, -ēre, -uī, - be concealed, be hid, escape notice.

obiciō, -ere, -iēcī, -iectum, oppose, expose.

omittō, -ere, -mīsī, leave out of -missum,

praetermittō, -ere, -misī, -missum, consideration, overlook, pass over.

ōrdō, ōrdinis, m., rank, class, body (of men).

pertineō, -ēre, -ūi, -, extend, have to do with, concern; with ad and acc.

restat, -stāre, -stitī, ] it remains. reliquum est, etc., $\quad$ Cf. 264 . sequitur, sequī, secūtum est, the result is. Cf. 264.

templum, - $\mathrm{i}, \mathrm{n} .$, temple, consecrated ground.

tueor, tuērī, tūtus sum, gaze at, watch, watch over, protect. ut ... nōn may sometimes be translated "without." Cf. 259, $a$.

\section{LESSON XIII}

amāns, amantis, loving, fond of; amāns patriae (rei pūblicae), patriotic. 
aspiciō, -ere, -spexī, -spectum, behold.

āvertō, -ere, āvertī, āversum, turn away, turn aside, avert.

caedēs, caedis, f., murder, death. celebrō, -āre, -āvī, -ātum, throng, attend in crowds; celebrate.

cīvīis, -e, civil.

condō, -ere, condidī, conditum, found; store up.

cōnferō, -ferre, -tulī, -lātum, compare.

dēiciō, -ere, -iēcī, -iectum, cast down, throw down, overturn.

forum, $-\overline{\mathbf{l}}, \mathrm{n} .$, forum.

hodiē, (adv.), to-day.

hodiernus diēs, hodiern̄̄ diēī, m., noun, to-day, this day.

impendeō, -ēre, -, - overhang, threaten.

iūstus, -a, -um, just, impartial. mōnstrum, -ī, n., portent, omen. monumentum, -ī, n., monument, memorial.

plācō, -āre, -āvī, -ātum, placate, appease, win over.

poena, -ae, f., punishment.

post hominum memoriam, within

the memory of man.

sapiēns, sapientis, wise; as a noun, a wise man, a philosopher.

simulācrum, -ī, n., image, statue, representation.

\section{LESSON XIV}

autem, postpositive particle, but, on the other hand, however; moreover. Cf. 412, 1.

careō, -ère, -uī, -itūrus, be without, go without, lack. Cf. 153. concitō, --āre, -āvī, -ātum, arouse, excite, stir up.

culpa, -ae, f., blame, fault.

dēcrētum, -ī, n., decree.

dignus, -a, -um, worthy, deserving.

Cf. 145. dignus est quĩ -. Cf. 275,1 .

exterus, -a, -um, outside, foreign. faveō, -ēre, fāvī, fautum, favor. Cf. 80.

impetrō, -āre, -āvī, -ātum, gain a request, be successful in gaining a request.

indignus, -a, -um, unworthy, not worthy, undeserving. Cf. 145. indignus est quī -. Cf. 275,1 . iniūria, -ae, f., harm, wrong.

invidia, -ae, f., hatred, unpopularity, enmity.

iūdicium, -ī, n., judgment, decision, trial.

pariō, -ere, peperī, partum, produce, acquire, gain.

prōpōnō, -ere, -posuī, -positum, set before, set forth, present.

quicumque, quaecumque, quod-

cumque, whatever, whatsoever.

sānē (adv.), indeed, to be sure, surely. unniversus, -a, -um, all, the whole of, as a whole.

uxor, -ōris, f., wife.

\section{LESSON XV}

dēterreō, -ēre, -uī, -itum, deter, prevent. Cf. 269-270.

impediō, -īre, -īvī or -īi, -ītum, hinder, prevent. Cf. 269-270.

prohibeō, -ēre, -uī, -itum, hold back, hinder, prevent. Cf. 271. dubitō, -āre, -āvī, -ātum, hesitate.

Cf. 273 . doubt. Cf. 272. 
dubius, -a, -um, doubtful; nōn dubium est quin, there is no doubt that; nēminī dubium est quin, no one doubts that. Cf. 272.

nefärius, -a, -um, wicked.

nūdius tertius, the day before yesterday. This is an adverbial expression and does not change its form.

poenās pendō (-ere, ] pay the

pependī, pēnsum), penalty, poenäs dō (dare, suffer

dedī, datum), J punishment. quin, |from. For distincquōminus, $\}$ tion in use, see 269 , nē, 272 .

recūsō, -āre, -āvī, -ātum, refuse. Cf. 269-270.

retineō, -ēre, -uī, -tentum, hold back, restrain. Cf. 269-270. sententiam sequor (sequī, secūtus sum), follow advice. sevēritās, -tātis, f., severity, harshness.

ūtor, ūtī, ūsus sum, use, employ, enjoy. Cf. 165.

vinculum, $-\overline{1}, \mathrm{n} .$, chain. vincula, -ōrum, n. pl., may be used for "imprisonment."

\section{LESSON XVI}

amor, -ōris, m., love; amor patriae

or amor reī pūblicae, patriotism. cārus, -a, -um, dear, beloved. concordia, -ae, f., harmony. cōnferō, -ferre, -tulī, -lātum, contribute.

cōniūnx, cōniugis, m. and f., wife, husband, spouse. cōnsentiō, -īre, -sēnsī, -sēnsum, agree; with cum and the abl. case.

cōnsulătus, -ūs, m., consulship.

dēsum, -esse, -fuī, -futūrus, be wanting, fail; with the dat. case.

fax, facis, f., torch, firebrand.

in perpetuum, forever.

morior, morī, mortuus sum, die; mortuus, -a, -um, dead.

obsideō, -ēre, -sēdī, -sessum, besiege.

quisquam, quicquam, any one, anything (at all). Cf. 49.

sollicitō, -āre, -āvī, -ātum, disturb, incite, rouse, excite, tempt. excitō, -āre, -āvī, -ātum, arouse, stir up, excite, incite.

tantus . . . quantus, as large as, as great as, as much as, Cf. 43 . trucīdō, -āre, -āvī, -ātum, slaughter, butcher, kill.

üllus, -a, -um, any. Cf. 49.

utinam, would that! $O$ that! Cf. 226-229.

voluntās, -tātis, f., will, wish, good will, loyalty.

\section{LESSON XVII}

acsī, quasi, tamquamsī, as if, as though. Cf. velutsī, $\left.\begin{array}{l}\text { aeternus, -a, -um, } \\ \text { sempiternus, -a, -um, }\end{array}\right\} \begin{aligned} & \text { perpetual, } \\ & \text { everlasting }\end{aligned}$ perpetuus, -a, -um, everlasting. afficiō, -ere, -fēcī, -fectum, treat; honōre afficiō, treat with honor, honor.

conciliō, -āre, -āvī, -ātum, win over, conciliate. 
continuus, -a, -um, consecutive,|fallō, -ere, fefellī, falsum, desuccessive, in succession.

dēpellō, -ere, -pulī, -pulsum, turn aside, avert.

domesticus, -a, -um, domestic, civil.

fïrmus, -a, -um, strong, secure. immittō, -ere, -mīsī, -missum, send in, let in, let loose.

inopia, -ae, f., lack, want. inimicitia, -ae, f., enmity, hostility, unfriendliness.

inveniō, -īre, -vēnī, -ventum, find. libenter, adv., gladly, freely.

minae, -ārum, f. pl., threats; vì et minis, with threats of force. nōndum, not yet.

occultō, sēcrētō, $\}$ apart, in secret, secretly. temerē (adv.), rashly, without reason, recklessly.

tremō, -ere, -uī, -, tremble, tremble at; with acc. vix, barely.

\section{LESSON XVIII}

agō, agere, ēgī, āctum, do, act, treat; in the passive, be at stake; dē aliquā rē agitur, it is a question of something. ascendō, -ere, ascendī, ascēnsum, ascend, mount.

commendō, -āre, -āvī, -ātum, intrust.

cōpia, -ae, f., plenty, fluency. cotīdiānus, -a, -um, daily (adj.). cūrō, -āre, -āvī, -ātum, care for, arrange for, provide for. Cf. 382 . dëdecus, -oris, n., disgrace.

exercitātiō, -ōnis, f., practice, training. ceive, disappoint, trick, delude. gradus, -ūs, m., step, grade. grātus, -a, -um, pleasing. innocēns, -entis, harmless, innocent.

lēgem referō (-ferre, rettulī, relātum), propose a law; . . before ... ad ...

mē dēđō, -ere, dēdidī, dēditum, I devote myself, etc.

memoriā teneō, -ēre, -uī, tentum, keep in mind, remember. mīrābilis, -e, wonderful. modus, -ī, m., limit, moderation. nocēns, nocentis, m., wrongdoer. populāris, -e, popular, democratic. quisquis, quicquid (quodquod), whoever, whatever; quicquid possum, whatever power I have. tribuō, -ere, tribuī, tribūtum, attribute, devote, assign.

vectīgal, -ālis, n., revenue, tribute, tax.

virtūs, -tūtis, f., ability.

\section{LESSON XIX}

appellō, -āre, -āvī, -ātum, address, call.

collocō, -āre, -āvī, -ātum, place, invest.

excellō, -ere, - (excelsum), excel, surpass. With dat. case.

exerceō, -ēre, -uī, -itum, train, administer, farm (the revenues).

exigō, -ere, -ēgī, -āctum, exact, collect.

fertilitās, -tātis, f., fertility.

fortūnae, -ārum, f. pl., f fortunes, rēs, rẽrum, f. pl., $\}$ property. 
frūctus, -ūs, m., fruit, product, source of revenue. minor, -ārī, -ātus sum, threaten. pecūnia, -ae, f., money. superbus, -a, -um, proud, haughty; superbē, adv., proudly, haughtily. temperantia, ae, f., moderation, self-restraint.

tot, indecl., so many; tot . . . quot, as many as, so many as. Cf. 43.

trādō, -ere, trādidī, trāditum, hand over, hand down, bequeath.

ulcīscor, ulcīscī, ultus sum, avenge, punish.

varietās, -tātis, f., variety. vectīgālis, -e, tributary.

\section{LESSON XX}

cōnficiō, -ere, -fēcī, -fectum, finish; bellum cōnficiō, bring $a$ war to a successful conclusion. fortasse, (adv.), perhaps. redintegrō, -āre, -āvī, -ātum, renew. renovō, -āre, -āvī, -ātum, rēgius, -a, -um, of the king, with the king, royal. revocō, -āre, āvī, -ātum; recall, call back.

\section{LESSON XXI}

āgnōscō, -ere, āgnōvī, āgnitum, recognize, identify, acknowledge (as one's own).

aurum, -ī, n., gold. avăritia, -ae, f., greed. cupiditās,• -tātis, f., desire, eagerness, greed.

crūdēlitās, -tātis, f., cruelty. contineō, -ēre, -uĩ, -tentum, control, hold in.

exemplum, -ī, n., precedent.

fēlīitās, -tātis, f., good luck, success.

gaudeō, gaudēre, gāvīsus sum, rejoice.

in aliquō est haec rès, some one possesses this quality.

insignis, -e, distinguished, exceptional.

mē gerō (-ere, gessī, ]

gestum),

gestum),
mè agō (-ere, ègī,
āctum),

praedō, -ōnis, m., robber, pirate.

quae cum ita sint, since this is so, this being the case, under these circumstances, therefore.

quoniam, since, because. Cf. 294-297.

quia, because. Cf. 294-296.

quod, since. Cf. 292

testis, testis, m., witness.

triumphō, -āre, -āvī, -ātum, celebrate a triumph; ... dē aliquō, celebrate a triumph for a victory over some one.

vexō, -āre, -āvī, -ātum, harass, lay waste.

\section{LESSON XXII}

alius, alia, aliud, another, other, different.

cēdō, -ere, cessī, cessum, yield, conform to.

cum, although. Cf. 315 .

etsī, etiamsī, tametsi. 322 . 
ut, though, granted that. Nega- ōrnō, -āre, -āvī, -ātum, decorate; tive, nē. Cf. 321 .

quamvis, however much, although. Cf. 319 .

licet, it may be that, although. Cf. 320 .

quamquam, in spite of the fact that, although. Cf. 317-318. At the beginning of a sentence, and yet.

in fugam dõ (dare, dedī, datum),

in fugam coniciō (-ere, flight. -iēcī, -iectum),

lacessō, -ere, -īvī, -ītum, challenge, provoke, harass.

minuō, -ere, minū̄, minūtum, lessen, diminish. For the Eng. intransitive verb the passive must be used.

frūstrā, adv., | to no purpose, nēquīquam, adv., $\}$ in vain. persequor, -sequī, -secūtus sum, prosecute.

pestis, pestis, f., plague, ruin, bane.

praestat, praestāre, praestitit, impersonal verb, it is better. retardō, -āre, -āvī, -ātum, check, hold in check, delay, retard. secundus, -a, -um, favorable. supplex, supplicis, m. and. f., suppliant.

totiēns, so many times.

turpis, -e, disgraceful, shameful. ūtilitās, -tātis, f., need, necessity, advantage.

\section{LESSON XXIII}

armō, -āre, -āvī, -ātum, arm; of ships, equip.

of ships, equip.

attribuō, -ere, -tribui, -tribūtum, assign.

classis, -is, f., fleet.

coörior, coörīīi, coörtus sum, arise, spring up.

dissentiō, -īre, -sēnsī, -sēnsum, disagree.

lēgem rogō, propose a law.

nāvālis, -e, naval, of ships, on the sea.

orbis, -is, m., circle; orbis terrae (or orbis terrārum), the earth. postquam, after. Cf. 283.

praetor, -ōris, m., praetor.

pristinus, -a, -um, former, old

time.

quaestor, -ōris, m., quaestor.

redimō, -ere, -ēmī, -ēmptum, buy back, ransom.

refertus, -a, -um, full of, crowded with. Cf. 115.

restituō, -ere, -stituī, -stitūtum, restore, reëstablish.

salvus, -a, -um, safe.

sicut, just as.

simulatque or simulac, as soon as. simulatque is commonly used before vowels.

singuläris, -e, unusual, exceptional, distinguished.

ubi, when. Cf. 283.

\section{LESSON XXIV}

$\left.\begin{array}{l}\text { antequam, } \\ \text { priusquam, }\end{array}\right\}$ before. Cf. 289.

celeritās, -tātis, f., quickness, dispatch.

dēcēdō, -ere, -cessī, -cessum, withdraw. 
dum, while; until; provided. 285-288, 290.

ex senātūs cōnsultō, in accordance with a decree of the senate.

fidēs, -eĩ, f., integrity.

fīnem faciō (-ere, fēcī, factum), make an end, finish.

intermittō, -ere, -mīsī, -missum, send between; in the passive, elapse, intervene.

latebrae, -ārum, f., pl., hiding places.

omnīnō, (adv.), altogether; with negatives, at all.

pereō, -īre, -ī̄, -itum, perish.

plūs valeō (-ēre, $-u \bar{i}$, -itūrus),

plūs possum (posse, prevail. Cf. potuĩ, -), 66.

vincō, -ere, vīcī, victum,

quam diū, as long as. Cf. 285. quīnquāgintã, indecl. numeral, fifty. quoad, as long as, while. Cf. 285-288.

quoque, (adv.), also, postpositive. Cf. 412.

\section{LESSON XXV}

armātus, -a, -um, armed. As a noun, an armed man.

inermis, -e, unarmed. cōnspicor, -ārī, -ātus sum, catch sight of, espy.

dissēnsiō, -ōnis, f., disagreement, dissension, disturbance.

fleō, -ēre, -ēvī, -ētum, weep. frōns, frontis, f., front; ā fronte, in front.

fugiēns, -entis, fleeing. As a noun, a fugitive. hic, (adv.), here, at this point. imperātum, -ī, n., order, bidding. interior; interius, inland, inside, inner, interior.

iniquus, .. -a, ,-um, unequal, unfavorable.

lapis, lapidis, m., stone.

latus, lateris, n., side, flank; ab latere, on the flank; ab apertō latere, on the exposed (right) flank.

perturbō, -āre, -āvī, -ātum, throw into confusion, disturb.

positus, -a, -um, situated.

quam primum, as soon as possible.

cum primum, as soon as.

reiciō, -ere, reiēcī, reiectum, cast back, drive back.

rēs gestae, rērum gestārum, f. pl., achievements, exploits, deeds.

sīgna inferō (īnferre, intulī, inlātum), advance (to the attack). tergum, -ī, n., back; ã tergō, from the rear, on the rear.

\section{LESSON XXVI}

absēns, absentis, absent, in the absence of.

concīdō, -ere, -cīdī, -cīsum, cut to pieces, cut down.

condiciō, -ōnis, f., terms, lot, condition.

domicilium, -ī, n., dwelling, home. exigō, -ere, exēgī, exāctum, spend, pass (time).

ineunte aestāte, when summer was coming on.

prīmā aestāte, in the first part of summer, in early summer. Cf. 108. 


\section{LATIN COMPOSITION}

instō, -āre, -stitī, be close at hand.

lātum), fall back, retreat.

integer, -gra, -grum, untouched, unharmed, unaffected. intereā, \} meanwhile, in the meaninterim, $\}$ time.

mandō, -āre, -āvī, -ātum, put into one's hands, intrust; command, commission. With dative of the person.

obsidiō, -ōnis, f., siege.

offerō, offerre, obtulī, oblātum, offer.

potestās, -tātis, f., power, control. praesēns, praesentis, present, in person.

quisquam, quicquam, any one (at all), anything (at all). Used only when a negative is expressed or implied. Cf. 49.

victor, -ōris, m., victor, conqueror. With the force of an adjective, victorious.

vivus, -a, -um, alive, living. 


\section{REFERENCES TO GRAMMARS}

\section{PART II}

Note. All the constructions employed in the lessons are explained fully in the Elements of Syntax, which comprises the first portion of this book. The following references are for use in connection with the grammars of Gildersleeve and Lodge (G.), Allen and Greenough (A.), Bennett (B.), and Harkness (H), where such reference is desired. The references in parentheses are to the older edition of Allen and Greenough.

Lesson I. Questions; Tense Sequence; Active Periphrastic

1. Direct Questions: G. 453-456; A. 331-332, $a-b(210, a, c)$; B. 162, 1-2, $a-c ;$ H. 378, 2 .

2. Interrogative Pronouns: G. 106; A. 148 (104); B. 90; H. 183, 184, 1-3, 511, 2.

3. Indirect Questions: G. 467, 460, (a), (b); A. 573-575 (334); B. $300, a-c ;$ H. 649 , II, $2,3$.

4. Active Periphrastic: G. 514, (b), 515; A. 575, a (334, a); B. 269,3 ; H. 649, II, 1.

5. Sequence of Tenses: G. 509-511, 514; A. 480-485, $a, b$ (283$287, a, b)$; B. 266-268, 1, 269; H. 543-545.

Lesson II. Genitive Case; Personal Pronouns; Direct REFLEXIVES

1. Description (Quality): G. 365,366 ; A. $345, a-b(215, a-b)$; B. $203,1,2,5$; H. $440,3,447$.

2. Possession: G. 362 ; A. $343, a-c(214, a-c)$; B. 198,$3 ; \mathrm{H}$. 440,1 .

3. Objective Genitive: G. 363 ; A. $347-348(217, a-c)$; B. 200; H. 440,2 . 
4. With Adjectives: G. 374 ; A. $349, a, b(218, a-b)$; B. 204, 1; H. 450, 451, 1-3.

5. Personal Pronouns: G. 304, 1-3; A. 295, $a-b(194, a-b)$; B. 242, 1-2, 243; H. 500, 4, 501, 2.

6. Direct Reflexives: G. 308, 309; A. 296, 2, 299 (195, 196); B. 244, 1, 247, 2; H. 502, 503, 1.

\section{Lesson III. Genitive with Verbs}

1. Verbs of Memory, etc.: G. 376 ; A. $350, a, b, d(219, a-b)$; B. 206 ; H. 454-455.

2. Verbs of Reminding, etc.: G. 376 ; A. $351(219, c)$; B. 207 ; H. 456 .

3. Verbs of Emotion, etc.: G. 377 ; A. 354, $a-c(221, a-c)$; B. 209; H. 457, 1-3.

4. Verbs of Accusing, etc.: G. 378; A. 352 (220); B. 208; H. 456.

5. Verbs of Rating, etc.: G. $379-380$; A. 417 (252, a); B. 203, 4; H. $448,1,4$.

6. Interest and Rēfert: G. 381-382; A. 355 (222); B. 210-211; H. 449, 1-3.

Lesson IV. Infinitives: SUbStantive and Complementary

1. Subjective Infinitive: G. 419-420, 422, 535; A. 452, 1-3, 454 $(270,1-3, b)$; B. 327,$330 ;$ H. $615,616,1,2$.

2. Complementary and Objective Infinitive: G. 423,532 ; A. 456458 (271); B. 328, 331, I-IV; H. 614.

3. Tense of the Auxiliary Verb: G. - ; A. 486, $a(288, a)$; B. 270,2 ; H. 618, 2 .

Lesson V. Indirect Discourse: Simple Sentences; Indirect ReFlexives

1. Simple Sentences in Indirect Discourse: G. 527, 648, 650; A. 578-581 (335, 1-2, a); B. 313-314; H. 613, 641, 642.

2. Tenses of Infinitive in Indirect Discourse: G. 529-530; A. 584 (336); B. 270, 1, $a-c$; H. 617-620.

3. Substitute for Future Infinitives: G. 248 ; R.; A. 569, $a$ (288, $f)$; B. 270,3 ; H. 619,2 .

4. Direct and Indirect Reflexives: G. 520,521 ; A. $300,1,2, a-b$ $(196, a, 2)$; B. 244, I-II, 249, 3; H. 502-504, 1-3. 


\section{Leisson VI. Indirect Discourse: Complex Sentences}

1. Review the References of Lesson V.

2. Complex Sentences in Indirect Discourse: G. 654, 655; A. 583, $585(336, .2, b, 336,$. B); B. 318 ; H. $643,1,644$.

3. Sequence of Tenses - General Rule: Cf. Lesson I, Reference 5.

4. Exceptional Sequences: G. 517, 518; A. $485, j(287, i) ;$ B. 268,2 ; H. 548.

Lesson ViI. Conditions: Logical (Simple) and Ideal (Less VIvid)

1. General Státements: G. 589-591, $(a),(b), 592,594$; A. $512, a$, $514, \mathrm{~A}, \mathrm{~B}(304, a, 305)$; B. 301,306 ; H. 572-573, 575, 2. 5.

2. Logical (Simple) Conditions: G. 595; A. 515, 516, 1, a; $c$ $(306,307,1, a, c)$; B. 302 ; H. 574.

3. Ideal (Less Vivid) Conditions: G. 596; A. 516, 2, b, $c$ (307, 2, $b, c)$; B. 303 ; H. 576.

Lesson Vili. Conditions: Unreal (Contrary to Fact) Conditions; Mixed Conditions

1. Unreal (Contrary to Fact) Conditions: G. 597; A. 517 (308); B. $304 ;$ H. 579.

2. Mixed Conditions: G. 593, 597, R. 1 ; A. $517, a, b(308, a)$; B. 304,2 , 305 ; H. 580-581.

3. Indicative in Unreal Apodoses: G. 597, R. 3; A. 517, $b-d$ $(308, c-d) ;$ B. $304,3, a)-b) ;$ H. $582,583$.

Lesson IX. Deliberative Questions; Rhetorical Questions; Double Questions

1. Deliberative Questions:\{ G.265; A. 443-444 (268); B. 162, 3,

2. Rhetorical Questions: $277, a$; H. 559, 4-5.

3. Double Questions: G. $458-460,2,461$; A. 334,335 , N. $a, d$ $(211$, R. $a, d)$; B. $162,4,300,4$; H. 380,1 .

\section{Lesson X. Dative Case; Opus Est and Ūsus Est}

1. Indirect Object: G. 344-345; A. 361-362 (224-225); B. 187, I; H. 424.

2. Dative with Special Verbs: G. 346 ; A. $367, a, c(227, a, c)$; B. 187, II, $a$; H. 426, 1-4. 
3. Impersonal Use of Special Verbs: G. 346, R. 1 ; A. $369, a$ (230); B. 187, II, $b$; H. 426, 3.

4. Dative with Compound Verbs: G. 347 ; A. 370 (228); B. 187, III; H. 429.

5. Reference (Interest): G. 350, 352; A. 376-379 (235); B. 188; H. $425,2,4$.

6. Purpose (Service): G. 356 ; A. $382,1(233, a) ;$ B. 191 ; H. $425,3,433$.

7. With Adjectives: G. 359 ; A. $383-385, a-b(234, b)$; B. 192, 1 ; H. 434, 2, 435, 1.

8. Possessor: G. 349 ; A. 373 (231); B. 190; H. 430.

9. Opus est and Ūsus est: G. 406 ; A. $411(243, e)$; B. 218, 2 : H. 477 , II .

Lesson XI. Purpose Clauses: Pure, Relative, and SubSTANTIVE

1. Pure Purpose Clauses: G. 545, 1-3; A. 530, 531, $1(317,1)$; B. $282,1, a-d$; H. 568 .

2. Relative Clauses of Purpose: G. 630 ; A. 531, 2, $a(317,2, b)$; B. 282,2 ; H. 590 .

3. Substantive Clauses of Purpose: G. 546, 1-2; A. 563, $a-d$ $(331, a-d)$; B. $295,1,2,4,5$; H. 564-566.

\section{Lesson XiI. Result Clauses; Result and Purpose} Contrasted

1. Result Clauses: G. 552, 1-2; A. 537, $1,2(319,1,2)$; B. 284 ; H. 570 .

2. Sequence in Result Clauses: G. 513; A. 485, c $(287, c)$; B. 268, 6; H. 550.

3. Substantive Clauses of Result: G. $553,1,3,4$; A. 568-571 (332, $a, 1-3)$; B. 297, 1-3; H. 571, 1-3.

4. Purpose and Result Contrasted: G. 543, 1-4; A. 538 (319, $d$, R.) ; B. - ; H. -

Lesson XIII. Commands; Prohibitions; Hortatory Subuunctive

1. Imperative: G. $266-268$; A. $448,449, a(269, c, d, e)$; B. 291,1 ; H. 560, $2,4$.

2. Prohibitions: G. 271, 2 (nōlī); A. $450(269, a, 2)$; B. 276, $c$; H. 561, 1.

3. Hortatory and Jussive Subjunctive: G. 263, 1, 3; A. 439 (266); B. 274, 275; H. 559, 1, 2 . 
Lesson XIV. Characteristic Clauses; Clauses after Verbs of Fearing

1. Characteristic Clauses: G. $631,1,2$; A. $535, a, b, f(331, a$, $b, f)$; B. $283,1,2$; H. 591, 1, 4, 5, 7 .

2. Clauses after Verbs of Fearing: G. $550,1,2$; A. $564(331, f)$; B. $296,2, a$; H. 567, 1-4.

Lesson XV. Verbs of Preventing, etc.; Verbs of Doubting; Review

1. Verbs of Preventing, etc.: G. 548, 549, 554, 555, 1; A. 558, $b(331, e, 2,332,2)$; B. 295, 3, $a$; H. 568, 8, 595, 2, 596, 2.

2. Verbs of Doubting: G. 555,2 ; A. $558, a$ (332, $g$, R.); B. 298; H. 595, 1, 596, 1 .

3. Review the References of Lessons XI, 3, XII, 3, XIV, 2.

\section{Lesson XVI. Wishes; Review of Conditions}

1. Wishes: G. $260-261$; A. $441,442, b(267, b, c)$; B. 279 ; H. $558,1,2,4$.

2. Review the References of Lessons VII and VIII.

Lesson XVII. Conditional Clauses of Comparison; Potential Subuunctive

1. Conditional Clauses of Comparison: G. 602 ; A. 524 (312); B. 307, 1, 2; H. 584 .

2. Potential Subjunctive: G. $257,1,2,258$; A. $446,447,1-3$ $(311, a)$; B. $280,1-4$; H. 552-557.

Lesson XVIII. Gerund; Gerundive; Supines

1. Gerund: G. 425-433; A. 501-502, 504-507 (295, 297-301); B. 338 ; H. 624-631.

2. Gerundive: G. $427-433$; A. 500, 504-507 (294, 297-301); B. 337,8 ; H. 622-631.

3. Gerund and Gerundive: G. 427 ; A. 503 (296); B. 338 ; H. $626,1$.

4. Supines: G. $434-436$; A. 508-510 (302-303); B. 340 ; H. 632 , 633, 635.

5. Purpose Constructions: G. 544, R. 2; A. 533, $a-d$ (318); B. - ; H. 634 . 
Lesson XiX. Passive Periphrastic; Ought and Must

1. Passive Periphrastic: G. 251, 1-2; A. 194, b (129); B. 337, 7, $b$; H. 621, 1, 2.

2. Dative of Agent: G. 355, R.; A. 374, $a$, N. 1 (232); B. 189, $1 ;$ H. 431.

3. Review Reference 1 of Lesson IV.

\section{Lesson XX. Conditions in Indirect Discourse}

1. General Statement: G. $656,1-3$; A. $589,1,2(337,1-2)$; B. $317-318$; H. 642,643 .

2. Logical (Simple) Conditions: G. 595, R. 1, 657; A. 589, 2, $a$, 1-3 (337, $a, 1-3)$; B. 319 ; H. 646.

3. Ideal (Less Vivid) Conditions: G. 596, R. 5, 658; A. 589, 2, $a$ $(337,2, a)$; B. 320 ; H. 646, 1.

4. Unreal (Contrary to Fact) Conditions: G. 597, R. 4, 659; A. $589,2, b, 1-4(337,2, b, 1-4) ;$ B. $321 ;$ H. $647,1-3$.

\section{Lesson XXI. Causal Clauses}

1. Cum-Causal: G. 586 ; A. 549 (326); B. 286, 2; H. 598.

2. Relative Clause of 'Cause: G. 633; A. 540, 2, c (321, 2, c); B. 283, 3; H. 592 .

3. Quod, Quia, Quoniam: G. 539-541; A. 540, 1, 2, a, b (321, 1, 2 , a); B. 286,1 ; H. 588 , I, II.

4. With Verbs of Emotion: G. 542; A.- ; B. - ; H.- -

\section{Lesson XXII. Concessive Clauses}

1. Concessive Conjunctions: G. 603; A. 527 (313); B. 309; H. $585-586,316,4$.

2. Cum-Concessive: G. 587 ; A. 549 (326); B. 309 , 3; H. 598.

3. Concessive Relative: G. 634 ; A. $535, e(313, h)$; H. 593,2 ; B. $283,3, b$.

4. Quamquam: G. 605 ; A. $507, d(313, f)$; B. 309,1 ; H. 586 , I.

5. Quamvis: G. 606; A. 527, $a(313, a)$; B. 309, 1 ; H. 586, II.

6. Licet: G. 607 ; A. $527, b .(313, b)$; B. 309,4 ; H. 586 , II.

7. Ut and Nẽ: G. 608 ; A. $527, a(313, a)$; B. - ; H. 586, II.

8. Etsī, Etiamsī, Tametsĩ: G. 604 ; A. 527, $c(313, c)$; B. 309, 2; H. 585,586 , I. 
Lesson XXIII. Temporal Clauses: Cum-Temporal; Postquam, ETC.

1. Cum-Temporal (and Historical): G. 579, I-II, $a, 580,581,584$, 585; A. 545, 546, $a, 547,548(325, a-c)$; B. 288, A, B, 2, 3, 289, $290,1,2 ;$ H. 600, I, II, 601, 1-4.

2. Postquam, etc.: G. 561 ; A. $543(324)$; B. 287 ; H. 602.

\section{Lesson XXIV. Dum Clauses: Priusquam and Antequam}

1. Dum, etc., Complete Coextension: G. 568-569; A. 556 (328); B. 293, II; H. 603, I.

2. Dum, etc., Partial Coextension: G. 568, 570; A. $555(328, a)$; B. 293, I; H. 604, 1.

3. Dum, etc., until: G. 571,572 ; A. $553-554$ (328); B. 293, III; H. 603, II.

4. Proviso: G. 573 ; A. 528 (314); B. 310 ; H. 587.

5. Priusquam and Antequam: G. 574-577; A. 551, $a-c$ (327); B. 291-292; H. 605, I-II.

\section{Lesson XXV. Partictples}

1. Formation and Use: G. 282-283; A. 488, 491-493 (289, 290, $a-c)$; B. 337 ; H. 636.

2. Tenses of Participles: G. 282-283; A. 489 (290); B. 336; H. 640.

3. Participles as Adjectives: G. 438; A. 494-495 (291); B. 337; H. 636.

4. Participles as Nouns: G. 437; A. - ; B. -; H. 494.

5. Participles for Clauses: G. 585, R., 593, 2, 609, 637; A. 496497 (292); B. 337, 2; H. 638-639.

\section{Lesson XXVi. Ablative Absolute}

1. Ablative Absolute: G. 409-410; A. 419 (255); B. 227; H. 489.

2. Ablative Absolute without Participle: G. 409; A. 419, $a$ (255, a); B. 227, 1; H. 489.

3. Ablative Absolute for Clause: G. 585, R., 593, 2, 609, 637; A. $420(255, d)$; B. 227,2 ; H. $489,1$.

4. When to use the Ablative Absolute: G. 410, 3; A. 419, N. (-); B. 227, 4; H. 489, 3.

5. Review Lesson XXV, Explanations, Part I. 



\section{PART III \\ LESSON I}

\section{PRONOUNS - ADJECTIVES - AGREEMENT}

609. REFERENCES :

.. Pronouns : $16-20,25-43,45-56$.

:. Adjectives : 1-3.
3. Apposition : 4-7.

4. Relative Agreement : 12-15.

5. Verb Agreement: 8-11.

\section{EXERCISE FOR WRITTEN TRANSLATION}

1. The Helvetians, who were a tribe of the Gauls, inhabited that part of Gaul which is bounded by the Alps.

2. A certain chief of the Helvetians, named ${ }^{1}$ Orgetorix, whose influence among them was very great, had formed a conspiracy.

3. The Helvetians had been influenced by him and other chiefs, and had determined to go forth from their territory.

4. Therefore they had made peace with all the states by which they were bounded, and all the men, women, and children were now ready to go forth.

5. Orgetorix himself had gone as ambassador to those states and (together) with Casticus and Dumnorix had determined to seize the royal power.

6. Of these (men) the former was a Sequanian whose father had been chief of that state, the latter was a chief of the Aeduans. 
7. These men interchanged an oath-bound pledge and attempted to seize the royal power.

8. This was reported to the Helvetians, and they ${ }^{1}$ determined to protect themselves and all their (property) against these men.

9. Without any delay they appointed a day and attempted to compel Orgetorix to plead his case in chains.

10. But he came to the trial with all his friends and was saved by them, (a thing) which greatly alarmed the Helvetians.

11. Then the Helvetians attempted by (force of) arms to compel him to plead his case, but on the very day of the trial Orgetorix died.

12. Either his enemies killed him or he killed himself.

13. After the death of Orgetorix his friends fled, some in one direction, others in another.

14. Dumnorix, the brother and at the same time the enemy of Diviciacus, made the same attempt in his state as Orgetorix had made among the Helvetians.

15. He was greatly alarmed by the death of Orgetorix, but through the influence of his brother escaped.

\section{Connected Prose:}

Orgetorix (the man) who formed this conspiracy, with (the aid of) Casticus and Dumnorix attempted to seize the royal power. But certain men reported this matter to the Helvetians, and they determined to compel him to plead his cause in chains. On the day of the trial he escaped, but afterward either killed himself or was killed by some enemy.

1 " and they" = "who." Cf. 41. 


\section{EXERCISE FOR ORAL TRANSLATION}

1. Many cities and villages. The cities and villages were small.

2. We who have formed this conspiracy.

3. You and your friends. I shall defend myself and my property.

4. You, your father, and I. From you and me.

5. We were fighting together. You have exchanged hostages.

6. On that very spot. On the self-same day.

7. If he says anything. I could not see anything at all.

8. The conspiracy of that scoundrel. That book of yours.

9. (It was) not I (who) told you, (but) you (who) told me.

10. The one always tells the other. Each one of them.

11. That famous general. He did just what he had said.

12. The men and women whom you see.

\section{LESSON II}

\section{TENSES OF THE INDICATIVE}

613. References :

1. Present Tense : 201-202.

2. Imperfect Tense : 203-205.

3. Future Tense : 212 .
4. Perfect 'Tense : 206-209.

5. Pluperfect Tense : 210-211.

6. Future Perfect Tense : 213.

\section{EXERCISE FOR WRITTEN TRANSLATION}

1. After the death of Orgetorix the Helvetians determined to do that which they had now for a long time been preparing to do. 
2. There were two routes by which they could go out: one through (the territory of) the Sequanians, the other through the Roman province.

3. First the Helvetians attempted to go through the province, but Caesar with those forces which he had with him in Gaul and the soldiers which he had collected from the province prevented them.

4. Then they attempted to march through (the territory of) the Sequanians, and had already arrived into (the territory of) the Aeduans and were devastating their fields.

5. When Caesar arrived the Helvetians were (in the act of) crossing the river, and the larger part of their forces had already been led across.

6. Caesar made an attack on the rest, and a large number of the enemy was killed by the Romans.

7. Then Divico and other ambassadors were sent to Caesar, and they treated him as follows:

8. "If you make peace with us, we will be friends of the Roman people, and will stay in the place where you wish us to be."

9. "If you remember the former valor with which the Helvetians were accustomed ${ }^{1}$ to fight, you will do this."

10. To this Caesar answered thus: "I remember those things which you have said, but I cannot grant you a passage through the province, for that neither I nor the Roman people is accustomed 2 to do."

11. "But if you will give hostages and will render satisfaction to the Aeduans, I will make peace with you."

1 Express in two ways.

2 With disjunctives the verb agrees with the nearest subject. 
12. Divico answered, "The Helvetians are accustomed to receive, not to give hostages."

13. Neither Caesar nor Divico was willing to make l eace, but both the former and the latter were ready for ivar.

14. On the following day the Helvetians broke camp. ' The Roman army did the same, and the cavalry began to follow the enemy.

15. For many days now they have been following the enemy, and they now know where the Helvetians have jitched ${ }^{1}$ camp.

\section{Connected Prose :}

Orgetorix had died, but nevertheless the Helvetians prepared to go out from their territory. The route through the Roman province was blocked by the fortifications which Caesar had made. Therefore they prepared to march through (the territory of) the Sequanians, and a great number of them had crossed the river. But Caesar's soldiers killed a large part of the rest, and compelled the Helvetians to send ambassadors (to treat) concerning peace.

\section{EXERCISE FOR ORAL TRANSLATION}

1. We are accustomed to receive hostages.

2. Caesar had already learned this. Caesar knew this.

3. They have now for a long time been preparing to go out from their territory.

4. For two years they had been attempting to do this.

5. A multitude of men arrived. 
6. Many villages, towns, and cities were burned.

7. You and I remember all this.

8. The cavalry ${ }^{1}$ had been sent ahead and the infantry ${ }^{1}$ followed.

9. You who have done this will be killed.

10. If he does this, he will be killed.

\section{LESSON III}

\section{THE ACCUSATIVE CASE}

617. ReFerences:

1. Direct Object : $60-61$.

5. Extent : 73-74, 169, 199-200.

2. With Compound Verbs : 62-63. 6. Limit of Motion : 187, 190-191.

3. Cognate Accusative : 64. 7. Double Accusative: 67-72.

4. Inner Object : 65-66.

8. Exclamation : 77 .

\section{EXERCISE FOR WRITTEN TRANSLATION}

1. For fifteen days Caesar followed the forces of the Helvetians which had crossed the river and were marching through the Aeduans' territory.

2. During all these days he kept asking the Aeduans for the grain which they had promised, for he had for many days been wondering at their delay.

3. Finally he called to him certain Aeduans, the chiefs of the state, and inquired of them the cause of the delay.

4. This ${ }^{2}$ the Aeduans attempted to conceal from him; but finally Liscus, who seemed braver than the rest, spoke as follows: ${ }^{3}$

1 What number will the verbs be if equitātus and peditātus are used ? If equitēs and peditēs are used?

2 Cf. 41.

8 "spoke as follows" = "said these (things)." 
5. "Dumnorix, whom the people call their friend, has more influence than the rest of the chiefs of the Aeduans and is holding back the grain."

6. Caesar made the same inquiries from the other chiefs; each one entertained the same opinion and made the same reply as Liscus (had made).

7. Caesar then called to him Diviciacus and Dumnorix, of whom the former had always remained the friend of the Romans, (while) the latter was considered their enemy.

8. Caesar then said, "You, Dumnorix, have made many promises, but you do not send the grain; therefore I give you this warning - if you remain an enemy of the Romans, you will be killed."

9. On that day scouts informed Caesar that the enemy had pitched camp at the foot of a hill. In this place the Romans could surround them.

10. Caesar had been waiting for this for fifteen days, for he was afraid to make an attack on so great a number of men in the open plain.

11. Therefore he surrounded the enemy's camp with his troops and prepared to make an attack on them from all sides at one time.

12. Considius, whom Caesar considered the bravest of all the scouts, had been ordered ${ }^{1}$ to give the signal for the attack.

13. But when the Romans had surrounded the enemy, Considius announced that the enemy's camp was not at the foot of the hill but on the hill, (a thing) which was not true. 
14. Therefore the attack was not made, and the Helvetians broke camp and said to each other, "The Romans despaired of victory even when they had surrounded us with their forces."

15. After this day Caesar and the soldiers entertained the same opinion about Considius and never afterward considered him the bravest scout.

\section{Connected Prose :}

On the next day Caesar did not follow the Helvetians, but set out for a town of the Aeduans in which there was a large supply of grain. The enemy then prepared to make an attack on Caesar, who drew up his forces on a hill and waited for them. The enemy could not surround Caesar with their greater multitude, and so, when the battle had lasted ${ }^{1}$ a long time, they were defeated. After the battle the Helvetians fled for many miles, but on the third day sent ambassadors and asked for peace.

\section{EXERCISE FOR ORAL TRANSLATION}

1 a. We have chosen the one as commander, the other we have elected consul.

b. The one has been chosen as commander, the other has been elected consul.

2. We have called him king and friend, but he has remained our enemy.

3. The latter shuddered at this conspiracy; the former laughed at it.

4. The ambassadors asked the general for peace, and he demanded hostages of them. 
5 a. They have made many inquiries. We have made no reply.

b. They have made many demands from you. What reply have you made?

6. Orgetorix had been made leader of the Helvetians.

7. The scouts shuddered at the troops of the enemy.

8. He tried to conceal himself from his friends.

9. He has crossed the river. He will lead his troops across the river.

10. They have prepared for war, but they despair of victory.

\section{LESSON IV}

\section{QUESTIONS: DIRECT AND INDIRECT - SEQUENCE OF}

\section{TENSES}

621. ReFERENCES :

1. Direct Questions, Indicative : 214-217.

2. Deliberative and Dubitative Questions : 218.

3. Rhetorical Questions : 219-220.

4. Double Disjunctive Questions: 221-222.

5. Answers : 223-225.

6. Indirect Questions : 251-252.

7. Sequence of Tenses : 242-246.

\section{EXERCISE FOR WRITTEN TRANSLATION}

1. Caesar made these inquiries from the ambassadors who came to him from many states of Gaul after the Helvetian war.

2. Have not the Sequanians and the Aeduans been fighting with each other for many years? "Yes," replied the ambassadors.

3. Which of these (two) tribes has chosen Ariovis- 
tus and the Germans as allies against the other? "The Sequanians," replied the Gauls.

4. Why should the Sequanians, who have conquered the Aeduans with Ariovistus's aid, be grieving at their fortune?

5. The ambassadors then asked Caesar whether he knew what sort of a man that Ariovistus was, and that he had made the lands of the Sequanians his province.

6. Caesar then asked, "Won't Ariovistus lead his troops back across the Rhine? He isn't going to remain in Gaul, is he?"

7. "What shall I do?" asked Caesar. "Shall I permit this German to dwell in the land of our allies? If the Gauls fear him and shudder at his cruelty, why may he not try to come into Italy?"

8. Caesar therefore asked Ariovistus through ambassadors whether he intended to remain in Gaul or lead his troops back across the Rhine.

9. Ariovistus made this reply: "Why should you, Caesar, come into my Gaul, which I have conquered?

10. If you wish to know what I intend to do, come to the place where I am, and you will learn.

11. If I am not accustomed to direct the Romans (as to) how they shall rule their province, why should they try to direct me (as to) how I shall rule the Sequanians?

12. If you come and contend with me in battle, then you will learn how powerful the Germans are in war."

13. After this message Caesar determined to lead his army against Ariovistus and to try (to see) whether ${ }^{1}$ he would then speak with the same boldness.

1 After cōnor and exspectō whether is translated by sì. 
14. He then came to Vesontio, and from the citizens of that town the soldiers learned how large and how brave in war the Germans were.

15. They shuddered at that which they heard, and asked Caesar whether he intended to fight with such men or not.

\section{Connected Prose:}

Caesar called a meeting of the soldiers and centurions and spoke as follows: "Ariovistus and his Germans are the same race that our fathers conquered. These Germans were not able, were they, to conquer the Helvetians, whom you have conquered? Why should you be afraid of the same men? Ariovistus did indeed conquer the Gauls, but strategy, not greater courage, gave him the victory. Who thinks that a German's strategy can deceive me, a Roman general ? This night I shall set out toward the enemy and try (to see) whether your fear or your (sense of) duty will conquer."

\section{EXERCISE FOR ORAL TRANSLATION}

1 a. Did Caesar begin battle on the left wing?

b. Caesar didn't begin battle on the left wing, did he? Didn't he begin battle on the right wing?

$2 a$. Who can endure the boldness of Ariovistus?

$b$. Who could have endured the boldness of Ariovistus?

3. Caesar said to himself, "Shall I renew the battle or make peace?"

4. Did Caesar conquer two enemies in one year or not? How many times did he fight? 
5. Every one wondered whether Caesar had conquered two enemies in one year or not.

6. Caesar was waiting (to see) whether the enemy would fight or not.

7. Caesar asked the tenth legion whether they were afraid of the Germans.

8. What is he doing? I wonder what he is doing. I wondered what he was doing.

9. What did he do? I wonder what he did. I wondered what he had done.

10. What is he going to do? I wonder what he is going to do. I wondered what he was going to do.

\section{LESSON V \\ PURPOSE AND RESULT CLAUSES}

625. REFERENCES :

1. Purpose Clauses : 253-257.

3. Result Clauses : $258-260$.

2. Substantive Clauses of Purpose : 4. Substantive Clauses of Result: 261-263. 264.

5. Negatives : 265 .

\section{EXERCISE FOR WRITTEN TRANSLATION}

1. By Caesar's speech the minds of all were so changed that the soldiers begged him to make an attack on the Germans at once.

2. Therefore Caesar set out during the fourth watch, but Ariovistus learned of this and sent ambassadors to ask him to treat with him concerning affairs in ${ }^{1}$ Gaul.

3. He demanded that no foot soldier be led to the conference, and that Caesar come with horsemen only. 
4. Caesar could not do this without exposing himself to great danger, for all his horsemen were Gauls.

5. Therefore, that he might the more safely go to the conference, he commanded the soldiers of the tenth legion to go with him on horseback. ${ }^{1}$

6. In the conference Caesar tried to persuade Ariovistus to return into Germany, and demanded that he should not inflict any injury on the Aeduans.

7. Ariovistus thus replied: "The Gauls themselves urged me to cross the Rhine, and I did this to aid them against their neighbors."

8. At this time it happened that the cavalry of Ariovistus made an attack on Caesar's horsemen and hurled their javelins at them.

9. Caesar warned his men not to hurl any weapon back at the enemy and did not permit ${ }^{2}$ the soldiers to fight.

10. Three days ${ }^{3}$ after this conference Ariovistus moved his camp with this plan, that he might cut Caesar off from his supplies.

11. It remained for Caesar to move his camp and make the enemy fight so that he might not be cut off from his supplies.

12. The Romans made so fierce an attack that the enemy could not withstand them, and the result was that all the Germans fled.

13. It happened that Procillus and Metius escaped from the Germans so that no one of Caesar's friends was killed.

14. Caesar employed the cavalry to overtake the Ger-

1 " on horseback" = "on horses."

${ }^{3}$ Cf. 174.

2 Write four times, using permittō, patior, sinō, vetō. 
mans, and the cavalry brought it about that few of the enemy escaped.

15. Added to this was the fact that the camp of Ariovistus was captured; and of his two daughters one was killed, the other captured.

\section{Connected Prose :}

When the Aeduans and the Arverni had been fighting together for many years, it happened that the Arverni and - the Sequanians sent for the Germans to aid them. Ariovistus, the king of the Germans, had therefore crossed the Rhine with all his forces, but he was so barbarous and cruel that the Gauls were forced to beg Caesar to aid them. This Caesar did, and made the Germans retreat across the Rhine.

\section{EXERCISE FOR ORAL TRANSLATION}

1. He did this that he might the more easily capture the city.

2. It remains for us to beg peace from them.

3. He is so cruel that no one can endure him.

4. He ordered that no one go forth from the city.

5. It happened that there was nothing in the town at that time.

6. There are so many soldiers that we cannot defend ourselves.

7. The senate decreed that he should send aid.

8. I shall ask him not to send aid.

9. He is said to have done this, that no one might escape.

10. I do not know why he sent men to do this.

11. Caesar freed Dumnorix on this condition, that after that time he should avoid suspicion. 


\section{LESSON VI \\ THE DATIVE CASE}

\section{ReferenCeS :}

1. Indirect Object: 78 .

4. Dative of the Possessor: 85-86.

2. Dative with Special Verbs : 79-82. 5. Dative of Purpose : 90-91.

3. Dative with Compound Verbs: 6. Dative with Adjectives : 92-96. 83-84.

7. Dative of Reference : 87.

\section{EXERCISE FOR WRITTEN TRANSLATION}

1. Several of the Belgian states desired a revolution, and these men with others persuaded the Belgians to make war on the Roman people.

2. This.matter was reported to Caesar, and he immediately commanded the Senones, who were nearest to the Belgians, to inform him (of) what the Belgians did.

3. The Remi, who of the Belgian tribes were nearest to the Gauls, sent ambassadors to Caesar to say that they were friendly to the Romans and were ready to obey Caesar's commands.

4. "The Bellovaci," they said, "are the most powerful of all the Belgians and have demanded for themselves the command of the whole war."

5. The Suessiones have a king, Galba by name, and this man the Belgians have put in charge of all their forces to look out for their interests and resist the power of the Romans.

6. Caesar trusted and believed the Remi, whose friendship pleased him; but nevertheless he demanded ${ }^{1}$ hostages of them.

7. The Belgians began to attack Bibrax, the largest 
town of the Remi; and Iccius, who was in charge of the town, sent a messenger to Caesar to ask for aid.

8. Caesar immediately sent soldiers to aid $^{1}$ the Remi, and himself with great speed hastened toward the town and chose a spot suitable for a camp.

9. Meanwhile the Aeduans were approaching the territory of the Bellovaci, and the latter could not be persuaded to remain longer.

10. Therefore during the second watch they set out from their camp with so much disorder that their departure seemed like a flight.

11. This fact was reported to Caesar and at daybreak he sent ahead Pedius, who was in command of the cavalry, and $\mathrm{he}^{2}$ killed a great number of the Bellovaci.

12. On the following day Caesar hastened to Noviodunum, a town of the Suessiones well fortified by nature, and began to prepare everything which was useful for a siege.

13. The Suessiones (were) alarmed by these things (and) sent ambassadors to say that they were ready to yield to Caesar and obey all his commands.

14. Caesar pardoned their wrongs and spared them, but that they might not afterward make war on the Roman people he demanded ${ }^{3}$ hostages of them.

15. Thus a tribe hostile to the Romans (was) defeated in a short time (and) was forced to obey Caesar's commands.

631. Connected Prose :

The Belgians, who were a tribe hostile to the Roman people, were persuaded by their chiefs to form a con- 
spiracy. But the Remi, who were a tribe of the Belgians, favored the Romans and reported this conspiracy to Caesar. He immediately went to the aid of the allies of the Roman people and quickly forced the Belgians and their friends to sue for peace. Still the Belgians were pardoned by Caesar, and they were given fields in the territory of the Aeduans.

\section{EXERCISE FOR ORAL TRANSLATION}

1. Few men are like Caesar. A city dear to the Romans.

2. The soldiers obey the general. The general is obeyed by the soldiers.

3. Caesar pardons the Belgians. The Belgians are pardoned by Caesar.

4. I gave him a book. He was given a book by me. I was given a book.

5. They ask his advice, and he ${ }^{1}$ consults their interests.

6. Caesar put him in command of the legion. He was put in command of the legion by Caesar. He is in command of the legion.

7. I will take care of that matter. The baggage was a great hindrance to the army.

8. You gave me a sword. You sent me a sword. I was sent a sword.

9. Caesar appointed a day for battle. I shall appoint a day for a conference.

10. Arms useful for war. A hill opposite and facing the city. 


\section{LESSON VII}

CLAUSES AFTER VERBS OF FEARING, PREVENTING, DOUBTING, ETC.-CHARACTERISTIC CLAUSES

633. REFERENCES:

1. Clauses after Verbs of Fearing: 266-268.

2. Clauses after Verbs of Preventing, etc. : 269-271.

3. Clauses after Verbs of Doubting : 272-273.

4. Characteristic Clauses : 274-276.

\section{EXERCISE FOR WRITTEN TRANSLATION}

1. There are some who consider the Nervii worthy of being called the bravest of all the Gauls.

2. These same Nervii were the only ones who had refused to send hostages to Caesar.

3. Therefore he decided to conquer them in order to prevent other tribes from joining with them.

4. Nevertheless there were some who did join with them, and in that region there was none who did not wish Caesar to be defeated.

5. Caesar did not doubt that he could conquer these tribes, and so did not hesitate to advance into the territory of the Nervii at once.

6. Each day he sent scouts ahead to choose a place suitable for pitching a camp. ${ }^{1}$

7. On the third day these scouts brought back (such) a message as ${ }^{2}$ not even Caesar could hear without great fear.

8. For in those places where the army then was there were fortifications (such) as ${ }^{2}$ could prevent the Romans from drawing up their troops.

1 " a suitable place in which a camp might be pitched."

2 "as" = "which." 
9. Caesar was afraid that they would make an attack on him, and he likewise feared that his troops could not withstand the attack.

10. He therefore proceeded to the river Sabis and drew up his forces on a hill which could be fortified.

11. Meanwhile the forest across the river concealed the enemy's forces, and a few horsemen were the only ones who could be seen.

12. However, when the enemy saw our troops they did not hesitate to cross the river, nor did they fear to advance to our very camp.

13. There were some whom the legions easily drove back across the river and even into the forest. The Nervii were the only ones who were not easily defeated.

14. The two legions which had been left to guard the camp could not withstand the attack of the Nervii, and even Caesar feared that the camp would be captured.

15. But the enemy were prevented from capturing the camp, for at that very time the rest of the legions returned and put them to flight.

\section{Connected Prose :}

Caesar did not consider his cavalry worthy of being sent into a sharp fight, for he always feared that they would not resist the enemy bravely. There was no band of foot soldiers which could not put them to flight. Caesar himself could not prevent them from fleeing from the enemy's infantry, but when this same infantry had been put to flight, the cavalry never hesitated to pursue and kill them. 
636. EXERCISE FOR ORAL TRANSLATION

1. Why should he hesitate to begin battle on the right wing?

2. Who is there who is afraid to cross the river?

3. They were afraid that they would be defeated. I was afraid that they would not be defeated.

4. They did not doubt that the general would be informed of the meeting.

5. Dumnorix will not prevent us from asking the Aeduans for grain, but he will prevent them from sending it.

6. We shall pitch our camp in a place such as ${ }^{1}$ we can easily fortify.

7. There were some who remained in the forest.

8. There was no one who did not hesitate.

9. Those who advanced are worthy of being praised by the general.

10. The Nervii were the only ones who bravely resisted our legions.

\section{LESSON VIII}

GERUND - GERUNDIVE-PASSIVE PERIPHRASTIC CONJUGATION - SUPINE

637. References :

1. Gerund : 376,381 .

3. Supines : $390-393$.

2. Gerundive : $377-382$.

4. Passive Periphrastic : $383-388$.

\section{EXERCISE FOR WRITTEN TRANSLATION}

1. This year Caesar had to conquer many Gallic tribes ; for the purpose of accomplishing this, he had to send his legions into many parts of Gaul. 
2. Galba had to go among the Seduni. When he had made a beginning of fortifying the camp there, the Gauls adopted the plan of making war on the Roman legions.

3. Galba's forces were not prepared to withstand the attack of so great a number, because many cohorts had gone from the camp for the purpose of seeking supplies.

4. Therefore Galba called a council of the centurions and asked what was to be done. They all said that they ought to remain inside the fortifications and await the enemy's attack.

5. But the Gauls made the attack so quickly that the centurions were not given time for stationing the soldiers on the fortifications.

6. Moreover, the number of the enemy was so great that the soldiers even (when) exhausted with wounds were given no chance to retire from the wall.

7. Therefore they made a sudden sally from all the gates and put the Gauls to flight. Thus the Gauls who had had hopes of crushing the Romans had themselves to withdraw.

8. Crassus, who was wintering near the sea, had to look after the army's grain supply; but the ambassadors whom he had sent to the Veneti to seek supplies were seized.

9. The Veneti knew how great a crime they had committed, and therefore arranged for ships to be built, and prepared everything which was useful for waging war.

10. The difficulty of waging war in these places was very great, for Caesar did not have ships suitable for navigating in such a sea.

11. Nevertheless he decided that he ought to defeat $\mathbf{x}$ 
the Veneti, for he remembered that his ambassadors had been held back by them - a thing which did not seem endurable.

12. For a large part of the year Caesar captured towns abandoned by the Veneti, but his hopes of defeating the Veneti themselves always failed him:

13. Therefore he had to wait for those ships which he had arranged to be built.

14. When they had come, the Veneti had to contend in a great naval battle because Caesar was prepared either to fight or to follow.

15. When all their ships had been destroyed in one battle by Caesar, the Veneti had to surrender all their towns because they had no further ${ }^{1}$ chance to defend them.

639. Connected Prose:

At the same time, Sabinus had to wage war with large forces of the Venelli, who had come into the hope of crushing the Roman legions. The number of the enemy was so great that Sabinus had to contend rather by strategy than by valor. He announced this plan of fighting to his centurions, "We must persuade some one to announce to the Venelli that we are not prepared for fighting." This was reported to the enemy, who then advanced to conquer the Romans, but were themselves defeated.

\section{EXERCISE FOR ORAL TRANSLATION}

1. Sabinus had to be sent against the Venelli.

2. Sabinus must wait for an opportunity to make a sally.

3. He must remain in camp. He must not depart. 
4. Sabinus must persuade a certain Gaul to announce this.

5. Love of fighting. For the sake of defending themselves. By abandoning their towns they escaped.

6. A chance for crushing the Gallic forces was offered to Caesar.

7. This swamp was not suitable for pitching a camp.

8. After the battle this is the best (thing) to do.

9. Some came to ask for help; others came to complain of wrongs.

10. One part of the army was given to Galba to be led against the Seduni.

\section{LESSON IX}

\section{THE GENITIVE CASE}

641. References :

1. Possession : 97-98, 100.

2. Description (Quality): 101-103.

3. Partitive Genitive : 104-107.

4. Summus, Medius, etc.: 108.

5. Objective Genitive with Nouns : 110-112.

6. Objective Genitive with Adjectives : 113-115.

642. EXERCISE FOR WRITTEN TRANSLATION

1. The tribe of the Suabians was by far the greatest of all the Germans and the most fond of war, and every year they used to lead to war a hundred thousand armed (men).

2. They allowed no wine or other things to be brought into their country, and by daily training they had become (capable) of the greatest labor.

3. The Usipetes and Tencteri, who were of the same race, had been driven from their territory by the Suabians and had seized a part of Gaul. 
4. Caesar, who was familiar with the customs of the Gauls and Germans, heard of this and immediately decided to wage war with the Germans.

5. When he was a few days' march from the Germans, ambassadors were sent to him to say that it was the custom of the Germans to resist their enemies.

6. Caesar thus replied: "It is not my custom nor (that) of the Roman people to grant fields in Gaul to any one. Those who cannot defend their own fields ought not to seize the fields of others."

7. It is not (befitting) my $\operatorname{dignity}^{1}$ nor (that) of the Roman people not to defend the fields of all of our allies from their enemies.

8. The ambassadors asked for a three days' delay; but Caesar knew that a large part of the enemy's cavalry was absent, and that (it was) for this (that) they were desirous of a delay.

9. Therefore the next day he marched (on) into the territory of the enemy, and when he was about twelve miles from them the ambassadors returned to him and again demanded a three days' delay.

10. But the cavalry of the enemy, whose number was eight hundred, attacked our (men), and seventy-four of our horsemen were killed.

11. It was the height of madness ${ }^{2}$ to delay longer, and so on the following day Caesar made an attack on the Germans' camp which had been pitched on the top of a hill.

12. The men resisted the Romans, but the rest of the 
multitude (composed) of women and children fled. For the Germans had set out with all of their (people).

13. When this war with the Germans had been finished, Caesar decided to cross the Rhine, (an undertaking) which was (one) of the greatest difficulty.

14. The Sugambri asked him what his design was and what business he had across the Rhine; but the Ubii asked for Caesar's aid, and he did not refuse (it).

15. He made a bridge of huge size, led all of his army across, and subdued the larger part of the German tribes.

643. Connected Prose :

Caesar feared that the Germans would become accustomed to cross the Rhine and would seize a large part of Gaul. That the allies of the Romans should be thus harassed was (befitting) neither his own dignity $^{1}$ nor (that) of the Roman people. Therefore he defeated the Germans who had already crossed, and, that others might not be led across, he built a bridge and waged war with the Germans in their own territory. Most of the German states made peace with Caesar, who then withdrew into Gaul and destroyed the bridge.

\section{EXERCISE FOR ORAL TRANSLATION}

1. Wars with the Gauls. A friend of all of us. The town of Geneva.

2. A ten-mile march. A six-foot wall. A war of this sort.

3. Who of us? Ten of us. All of us. Enough power. 
4. During the first part of the summer. The rest of the enemy. It is my (duty) to do this.

5. Your good will toward me. Unskilled in law. Forgetful of us. A leader of the enemy.

6. The memory of those wrongs. A desire for praise. The forum is full of citizens.

7. Of these (men) the one was a general, the other a consul.

8. You will have a sufficient guard.

9. Is any one of us ignorant (of) what plan you adopted?

10. He has as much power as you. The width of this river is one hundred feet.

\section{LESSON X}

\section{THE GENITIVE CASE (Concluded)}

645. REFERENCES:

1. With Verbs of Memory, etc.: 116. 3. With Verbs of Emotion : 118-120.

2. With Verbs of Reminding, etc.: 4. With Verbs of Accusing, etc.: 121. 117.

5. Indefinite Value : $122-123$.

6. With Interest and Rēfert: 124.

\section{EXERCISE FOR WRITTEN TRANSLATION}

1. Caesar recalled the wars with the Gauls and remembered the wrongs which the Britons had committed in those wars.

2. He wished to make the Britons repent those wrongs and therefore considered it of the greatest (importance) to transport his army across into Britain.

3. The Britons (were) warned of his plans through merchants (and) thought that it was to their interests to 
send ambassadors to Caesar for the purpose of seeking peace.

4. Caesar told the ambassadors of the wrongs of which he accused the Britons and sent them back together with a certain Commius, whose influence in those districts was considered of great (value).

5. It was to Caesar's advantage not to leave any enemy behind him, and so he pardoned the Morini and told them that he would forget the things which they had done.

6. Meanwhile the Morini, who (being) ignorant of our customs had made war on the Romans, repented their plans and sent ambassadors to Caesar.

7. Then Caesar set sail with a large number of soldiers and soon approached the shore of Britain, where he saw the tops of the hills covered with thousands of armed (men).

8. Therefore he proceeded about seven miles from that place and ordered the soldiers to disembark. This was (an undertaking) of the greatest difficulty, for the enemy tried to prevent them.

9. But the standard bearer of the tenth legion reminded the soldiers of their former valor and of their duty, and then they were ashamed of their fear.

10. Finally the Britons (were) overcome (and) again sent ambassadors to Caesar, who condemned them for their misdeeds, but had pity on them and pardoned them.

11. But some of Caesar's ships were destroyed by a storm, and the Britons, who thought that this was a good opportunity, forgot their surrender and attacked a part of Caesar's soldiers. 
12. Caesar, who had thought that the Britons would adopt some new plan, had his soldiers ready in arms and immediately sent them to aid his (men).

13. Several of the enemy were killed, but the rest of their forces retreated into camp and on the same day sent an embassy to Caesar for the sake of making peaçe.

14. Caesar thought it of little importance to remain longer in Britain, and therefore received the Britons in surrender and returned into Gaul.

15. When about three hundred of our (soldiers) had disembarked, the Morini, forgetful of those things which they had promised, made an attack on Caesar's soldiers, but were easily defeated.

647. Connected Prose:

These were Caesar's reasons for crossing over into Britain : first, because he did not think it (worthy) of his dignity nor (that) of the Roman people, to forget the things which the Britons had done. Moreover, Caesar wished to make the Britons remember the power of the Roman people and repent those injuries. Finally, he considered that it was of the greatest importance to learn about the people, harbors, and customs of the Britons.

\section{EXERCISE FOR ORAL TRANSLATION}

1. I cannot remember all this. I shall forget my speech.

2. I shall remind you of your speech if I can recall it.

3. He is ashamed of this. He is tired of war.

4. He was accused of a conspiracy and was condemned for the wrongs of which he was accused. 
5. It is to my interest and (that) of the general to do this.

6. The depth of that river was eight feet.

7. All of us. Ten of us. No one of us.

8. A desire for praise. Desirous of praise. Mindful of you.

9. In the middle of the city. On the end of the wall.

10. This is of no great importance to you, but is greatly to my interest.

\section{LESSON XI \\ CONDITIONS}

649. ReFERENCES :

1. General Statement: $298-300$.

3. Ideal Conditions: $303-304$.

2. Logical Conditions: 301-302, 311.

4. Unreal Conditions : $305-310$.

5. Protasis implied : 312 .

\section{EXERCISE FOR WRITTEN TRANSLATION}

1. If this most (strongly) fortified place of holding the senate does not move you, Catiline, you are a conspirator of the utmost daring.

2. If the consul has watched more sharply for the safety of the state than you (have) for its destruction, he has learned what plans you have adopted.

3. If the senate has decreed that the consul see to it that the state suffer ${ }^{1}$ no harm, why should I hesitate to obey the senate's decree?

4. Should I drive you into exile, you would be considered unfortunate; but if you were to go to Manlius, all would see that you are planning the state's destruction.

5. If I put you to death, Catiline, a storm of unpopu- 
larity will hang over me; if I do not put you to death, my country will condemn me for my inactivity.

6. If our native land knew what sentiment you hold concerning the state, you would not now be a participant in the public deliberations.

7. Had I considered this the best thing to do, that you be killed, I would not have given you one day to plot the destruction of us all.

8. There are some who do not believe that a conspiracy has been made; these ${ }^{1}$ would be calling me a tyrant if I had killed you.

9. If all (men) had believed that you were forming the greatest conspiracy within the memory of man, I would not have needed to hesitate to kill you.

10. Even if I were now a private citizen, nevertheless I ought to remain in the city and be looking out for the state.

11. If I had obeyed the decree of the senate and had put you to death, Catiline, I could not have driven out of the city the rest of the band of conspirators.

12. You, Catiline, (if) sent forth to the camp of Manlius, will take with you the sharers in your crime, and all will see that a conspiracy has been made.

13. A consul would be showing ${ }^{2}$ small gratitude to his country, if any fear of unpopularity should prevent him from putting to death men who are plotting the state's destruction. ${ }^{3}$

14. If the chief men of the state had not feared that you were preparing to kill them, would they have fled for the purpose of saving themselves? 
15. If you should go to Manlius's camp, Catiline, you would have a chance to show ${ }^{1}$ how bravely you can endure hunger and want of everything.

\section{Connected Prose :}

The seriate decreed that the consul should provide for the safety of the state. If in accordance with this decree I had put you to death or sent you into exile, the rest of your band of conspirators would have remained, and I should have had to endure a storm of unpopularity. But if you lead an army against Rome, as ${ }^{2}$ you have now for a long time wished (to do), if you make war on your native land, there will be no one who will not consider you as an enemy, and no one who will not praise my diligence.

\section{EXERCISE FOR ORAL TRANSLATION}

1. If he obeys the general, he will be praised.

2. If he does not obey the general, he will be put to death.

3. Unless the general were brave,

(a) he would not be thought worthy of 'being obeyed.

(b) he would not be obeyed.

(c) the soldiers would not obey him.

4. If we should avoid battle, the enemy would surround us; but if we make an attack, they will retreat.

5. If there is any danger, he does not see it. Convert this sentence into all the various forms of conditional sentences and translate each.

6. If any one were to tell me that, I should go forth from the city.

1 "have a chance to show" = "have where you might show."

2 Cf. 15. 
7. Even if he were afraid to go, yet he ought to be sent.

8. If we had given him a larger army, he could have saved the city.

9. If the enemy's forces are divided, we shall conquer.

10. If we had chosen him as commander, we should now be safe.

11. Catiline, (if he is) sent forth from the city, will plot its destruction.

12. If he finishes this war in one year, he will deserve to be praised.

\section{LESSON XII}

WISHES - POTENTIAL SUBJUNCTIVE - CONDITIONAL CLAUSES OF COMPARISON

653. REFERENCES :

1. Wishes (Optative Subjunctive): 226-231.

2. Potential Subjunctive : 232-235, 219.

3. Conditional Clauses of Comparison: 313.

654. EXERCISE FOR WRITTEN TRANSLATION

1. When Cicero had called together the senate, Catiline came (along) with the rest just as if he were worthy of being made a participant in the public deliberations.

2. You could have seen that Cicero wondered at the daring of the man, for he began his oration as if he were moved by hatred of Catiline.

3. "You, Catiline," said Cicero, "desire to destroy this city just as if it were a city of the enemy. Why should I permit you to live longer?"

4. Would that I had put you to death before. I would that all men would believe you to be a wicked citizen! 
5. Some one may ask why I have not arrested Catiline and led him to death. To those I would gladly make this answer.

6. I would that all citizens desired Catiline's death; but one would scarcely believe that so many citizens favor Catiline.

7. Furthermore, I should prefer that he leave Rome and take with him all his associates in crime rather than that he die and leave all his followers in the city.

8. Some one may ask what I know concerning Catiline's conspiracy. "Why," they ask, "should you be addressing him as if he were an enemy of the state?"

9. May these men listen carefully to what I am going to say! I know, just as if I myself had been present, that Catiline addressed his companions thus.

10. "I should like to set out to Manlius. Would that I had some one to ${ }^{1}$ put in charge of the burning of Rome and the killing of Cicero!"

11. Would that no one had been found to try to accomplish these things, but many wished to undertake the task as if it had been an honor.

12. I would that Catiline would set out to Manlius! Would that he had left Rome, and that he were now in the camp of the enemy!

13. I should prefer that he take with him all his associates! I would that we could call them soldiers of the enemy rather than fellow-citizens!

14. Then we might consider the city safe and ourselves 
free from danger. But why, Catiline, should I urge you to go to Manlius?

15. If I have hitherto acted as if I feared the unpopularity arising ${ }^{1}$ from great severity, who now can deny that I have done what was best (to do)?

655. Connected Prose:

One might have supposed that Cicero was watching not for the safety of the state, but for his own (safety). He, the consul, hesitated to kill Catiline, just as if the senate had not ordered him to look out for the safety of the state. But after this speech who could doubt that he acted with great foresight?

\section{EXERCISE FOR ORAL TRANSLATION}

1. Would that he would come at once! Would that he had come at once !

2. May he return to Italy! I would that he were returning to Italy!

3. I should prefer that he make no reply. I should prefer that he were making no reply. I should prefer that he had made no reply.

4. Some one will say. Some one may say.

5. Who can believe such a messenger? Who could have believed such a messenger?

6. You might hear the shouting in the forum.

7. You might have thought him to be the general.

8. He speaks with me as if I were his friend. He spoke to me as if I had been his friend. He speaks as if he had been elected consul.

9. May all who survive come as witnesses! 


\section{LESSON XIII}

\section{COMMANDS - ENTREATIES - PROHIBITIONS}

657. References :

1. Commands : 237-239, 241.

2. Prohibitions : $240,241$.

3. Hortatory Subjunctive : 236.

\section{EXERCISE FOR WRITTEN TRANSLATION}

1. Catiline has at last been driven out of the city, fellow-citizens, but do not think that he has abandoned his designs of fire and slaughter.

2. Remember that his associates in ${ }^{1}$ crime are still with us and, as you have done heretofore, defend your homes and this city, and be not afraid.

3. To these men I give this advice $:^{2}$ let them depart from the city at once; let them not permit Catiline to wait for them in vain.

4. Let Catiline collect his followers in(to) the camp of Manlius, if he will; but let him not try to oppose those forces to our army.

5. But if he does make that attempt, ${ }^{3}$ do not hesitate, fellow-citizens; lead out against him the legions which are now being gathered for us.

6. Let us not, however, fear that army of Catiline's, but let us prepare to drive out the conspirators who have remained in the city.

7. Let them either go forth or cease to conspire against the city, and to think of nothing except fire and slaughter.

\footnotetext{
1 "in " = "of." Cf. 113-114.

2 "give them this advice" = "advise them this."

3 " make that attempt" = "attempt that."
} 
8. Or if they remain in the city and in the same (frame of) mind, let them expect the punishment which they deserve.

9. If, however, these men do remain in the city and in the same (state of) mind, know that we shall always be in great danger.

10. Recall what classes of men Catiline has gathered together, and judge whether men of that sort can harm the state or not.

11. Some say that I drove Catiline into exile by my words. ${ }^{1}$ But believe me, Catiline does not intend to go into exile.

12. Let it be said that Catiline was cast out of the city by me, but let him not think that I now fear the unpopularity arising from that term. ${ }^{2}$

13. Yet these (are the words which) I said to him: "Set forth from the city, Catiline; do not delay. Lead forth with you all your followers. Free the city from fear."

14. Do not forget that I, the consul, am keeping a sharp watch for the safety of the state and cease to attempt to destroy it.

15. If with such words (as these) I drove Catiline into exile, let us rejoice and hope that his followers will likewise depart from the city.

\section{Connected Prose:}

Cicero in the first oration against Catiline spoke as follows: "Change that purpose of yours, Catiline, and give up your thought of ${ }^{3}$ murder and fire: Depart from the 
city and free the state from fear ; betake yourself to Manlius and make war on your native land; let your followers depart with you, and let no wicked man remain in the city."

660. EXERCISE FOR ORAL TRANSLATION

1. Believe the consul. Conjugate this in the imperative constructions affirmative on the model given in 241 .

2. Do not hesitate. Conjugate this on the imperative constructions negative on the model given in 241 .

3. Consult your own interests; preserve yourselves; defend the name and safety of the Roman people.

4. See (to it), fellow-citizens, that the state does not suffer any harm.

5. Let us decide at once; let us not delay. Do not delay.

6. Tell me what you wish, Catiline; don't be afraid to speak.

7. Know, Catiline, that I shall keep a sharp watch for the safety of the state.

8. Remember what I have told you, my friend ; ... my friends.

9. Do not cease to defend your homes, fellow-citizens.

10. Let them say that if they wish.

\section{LESSON XIV}

\section{THE INFINITIVE}

661. ReFERENCES :

1. Infinitive as Subject: $323-324$.

2. Infinitive as Object : $331-332$.

3. Infinitive with Impersonal Verbs : 325-327.

4. Complementary Infinitive: $328-330$. 


\section{EXERCISE FOR WRITTEN TRANSLATION}

1. I ought not to have spoken so long about an enemy who has already left the city and is now hastening to go to the camp of Manlius.

2. (As for) those who have preferred to be in the city and who dare to remain with us, I desire not so much to punish (them) as to win (them) over to (the side of) the state.

3. And ${ }^{1} \mathrm{I}$ do not ${ }^{1}$ know why this cannot be done if they are willing to listen to ${ }^{2}$ me and forget the designs of Catiline.

4. Of these men, some are in great debt and yet seem to hesitate to do that which they ought to have done before this.

5. It is indeed very foolish for these men to remain in debt, but they cannot be persuaded to free themselves.

6. There are others who desire to get control of affairs, but who despair of being able to accomplish this when the state is undisturbed. ${ }^{3}$

7. It is necessary for these men to understand these (facts; namely,) that I am looking out for (the interests of) the state, and that we have large forces of soldiers.

8. The third class is (composed) of the soldiers of Sulla, and these men must be ordered to cease plotting against the state.

9. Others are so deeply in debt $^{4}$ that they may remain with Catiline without danger to the state.

1 neque. Cf. $394 . \quad{ }^{3}$ Cf. 370.

2 "listen to" = "hear." 4 " so deeply in debt "= " in so great debt." 
10. The fifth class is (composed) of all (sorts of) criminals, - (men) who from their youth ${ }^{1}$ (up) have learned to murder and commit all (sorts of) crimes.

11. From these facts, fellow-citizens, you may understand what these men are attempting to accomplish and what you ought to do.

12. (It is) against these forces (that) we must wage war, and (it is) against these men (that) we have determined to lead forth the flower and strength of Italy.

13. Therefore we ought not to fear, for even if the efforts of men should fail, the immortal gods themselves would force these scoundrels to be conquered.

14. It is my (duty) to crush this conspiracy, and I have determined to show you what it is your (duty) to do.

15. The immortal gods used to defend this city from its enemies, and you ought now to implore them to preserve it.

\section{Connected Prose:}

When Catiline had been driven forth from the city, his associates in crime attempted to carry out his designs and prepared to join their forces with the army of Catiline. Cicero knew this and tried to check the attempts of these wicked men. It was the duty of the consul to announce to the people what had happened, and therefore Cicero in the second oration against Catiline showed what the followers of Catiline ${ }^{2}$ were attempting to accomplish and what they ${ }^{3}$ ought to do. 
664. EXERCISE FOR ORAL TRANSLATION

1. You may do this. You ought to do this. You must do this.

2. You might have done this. You ought to have done this. You had to do this.

3. It is dangerous to attempt to do this.

4. It is the duty of the consul to defend the state.

5. I order you to depart. Translate twice, using iubeō and imperō.

6. He could not have prevented them from doing this. Translate three times, using prohibeō, impediō, dēterreō.

7. Catiline sent two Roman knights to kill Cicero. Give in four ways.

8. I dare not try to crush this conspiracy.

9. They begin to say. They began to say. It began to be said.

10. I desire to be lenient. I desire him to be lenient. I begged him to be lenient.

\section{LESSON XV}

THE INFINITIVE (Concluded)-INDIRECT DISCOURSE

665. ReFERENCES :

1. Infinitive in Indirect Discourse : 333-336.

2. Tenses of the Infinitive in Indirect Discourse : 337-343.

3. Personal and Impersonal Constructions : 344-345.

4. Indirect Discourse - Complex Sentences : 346-350, 250.

\section{EXERCISE FOR WRITTEN TRANSLATION}

1. In the third oration which was delivered before the people, Cicero said that the city which Catiline had wished to destroy had at last been saved. 
2. "There is no one," he said, "that will not say that I who have saved this city ought to be (held) in honor by 1 all good citizens."

3. You ought all to rejoice that this city which has often been threatened with ${ }^{2}$ destruction has escaped.

4. I promise to set forth to you all, those things which have been done regarding the conspirators.

5. After I saw that Catiline had left with us those who were sharers in his madness, I hoped to discover their plans.

6. I knew that certain envoys of the Allobroges had been bribed, that they had letters from the conspirators to Catiline, and that in a short time they would start from the city.

7. In the letters which were said to have been given to the Allobroges for Catiline there were proofs of the conspirators' crimes.

8. And so I hoped that I could arrest the Allobroges when they should have set out from the city, and that I could get possession of the letters which they were carrying.

9. Pomptinus and Flaccus promised to undertake the task of arresting the envoys and capturing the letters, and this mornitg they reported that they ${ }^{3}$ were waiting for me.

10. Many ading men said that I ought to open the letters before ${ }^{7}$ calling ${ }^{4}$ the senate together; nevertheless I said that I would not do that.

2 "tb "Yd with" = "called to." 4 " before I should have called." 
11. You know that the senate was called, that the testimony of the Gauls was heard, and that the letters which were captured were read.

12. Volturcius and the Gauls were greatly disturbed, but after we had promised that they would not be punished, they spoke freely.

13. They said that they had letters and instructions from the conspirators to Catiline, and that Catiline had been instructed ${ }^{1}$ to come to the city with his army as soon as possible.

14. They said also that the conspirators had urged them to join the conspirators, and even ${ }^{2}$ to send as many horsemen as possible against the city.

15. Lentulus is said to have been the chief of the conspirators, for he said that the power over the city ${ }^{3}$ would come to a certain Cornelius, and that he was that Cornelius.

\section{Connected Prose:}

Cicero said that when the evidence had been given, the conspirators, all of whom were present, looked at each other $^{4}$ as if they were accusing each other; and that some who could have denied the crin'e, confessed. He showed further that thanks had been osted to him and to others; that by the senate's decree 'entulus would be imprisoned when he should have resign ${ }_{f} d$ from office; and finally that the same decree had been 1 issed against the other conspirators, who had remained in the city with Lentulus.

1 "it had been instructed to Catiline."

3 Cf. 111.

2 Cf. 394.

4 ๆ. 26. 
668. EXERCISE FOR ORAL TRANSLATION

1. Cicero promised to save the city.

2. Cicero promises to save the city.

3. The citizens see that the city has been stripped of its defenders.

4. They see that they and their children have been saved.

5. 'They knew that Cicero alone had saved the city.

6. Many said that Catiline was not forming a conspiracy.

7. All good citizens rejoiced that Catiline had left the city.

8. Catiline is said to have set out. It was announced that Catiline had set out.

9. He who remains ${ }^{1}$ in the city will be safe. Give this sentence, depending on (a) Cōnsul dīcit ...; (b) Cōnsul dixit...

10. All men hoped that Catiline would either desist from his attempt or be killed.

\section{LESSON XVI}

\section{THE ABLATIVE CASE}

669. REFERENCES :

1. Means or Instrument: 127.

5. Cause : 135-137.

2. Agent : 128-130.

6. Accordance : 138-139.

3. Manner : 131-132.

7. Description (Quality) : 140-141.

4. Accompaniment: 133-134.

8. Specification (Respect): 142-145.

\section{EXERCISE FOR WRITTEN TRANSLATION}

1. The city (which had been) founded by Romulus had been saved by Cicero's diligence and the love of the immortal gods for the Romans. 
2. Cicero said that in his own opinion he was worthy of the highest honors. He announced that the senate had thanked him in the highest ${ }^{1}$ terms.

3. "The senate," he said, "has decreed a thanksgiving in my honor, ${ }^{2}$ and this I desire you to celebrate with your wives and children."

4. Then he explained in what way all the plans of the conspirators had been discovered and laid open by him.

5. When the Allobroges were leaving the city with instructions for Catiline, they were arrested at my command by certain men whom I had sent with arms.

6. The Allobroges, together with the conspirators, were led to the senate by my command. In accordance with the order of the senate they were given the public pledge.

7. For this reason they spoke freely and said that Catiline was being summoned with this purpose, that he might join with the leaders in the city.

8. The letters of the conspirators were all alike in this: they showed that men of the greatest daring had wished the barbarians to be joined with themselves.

9. For this reason the senate considered the conspirators worthy of imprisonment, and thought that because of their punishment the rest would leave the city.

10. Of all the conspirators, Catiline was the greatest in daring. If he had remained with us, we could not have saved the state with so little disturbance.

11. All these things seem to have been carried on, not 
by chance, but by the design of the immortal gods, and in accordance with the fates.

12. For when we were terrified by many omens, wise men ordered us to appease the gods, and in this way save the state from destruction. .

13. In accordance with their instructions, we decided to set up a statue of Jupiter. This was a task of so great difficulty that the statue was first set up to-day.

14. And so it happened that when you, with great pleasure, were seeing the statue for the first time, the conspirators were being led to prison by my orders.

15. Therefore a thanksgiving was justly decreed by the senate, for a most cruel civil war has been suppressed by me with very little disturbance.

\section{Connected Prose:}

In this war this principle was determined on by Catiline; (namely,) that all who were worthy of praise. should be killed. You remember with how great loss other civil disturbances were settled. With (even) greater loss would this war have been finished if Catiline had not been driven from the city by your consul.

\section{EXERCISE FOR ORAL TRANSLATION}

1. The city founded by Romulus has been saved by my diligence.

2. The ambassadors were leaving the city with this plan.

3. They went with letters; they were speaking with him; they will fight with him.

4. Cicero through (the help of) the praetors arrested the Allobroges. 
5. He did it with great swiftness, but unjustly.

6. The ambassadors did this at the command of a conspirator named Lentulus.

7. In my opinion they were justly and deservedly punished.

8. Men well disposed ${ }^{1}$ to us; ill disposed ${ }^{1}$ to us; he did this at his own risk; of his own accord.

9. A man of great daring, in which he surpassed many.

10. This will seem to have been done by chance, not with my consent.

\section{LESSON XVII \\ ABLATIVE CASE (Continued)}

736. ReFERENCES:

1. Place Where: 186.

2. Place Whence: 188.

3. Separation: $\mathbf{1 4 6 - 1 4 9 .}$

4. Verbs of Want, etc.: 153-154.

5. Time When: 167.

6. Origin : $150-151$.
7. Material : 152 .

8. Comparison: 157-162.

9. Measure of Difference : 160-162.

10. Price: 163.

11. $\overline{\mathrm{U}}$ tor, etc.: $165-166$.

12. Opus and Ūsus est: $155-156$.

\section{EXERCISE FOR WRITTEN TRANSLATION}

1. At last, senators, the city is free from danger and plots, and we have all been freed from the fear of death.

2. Catiline, despoiled of his arms of boldness, has been driven forth from the city, and his followers have desisted from their evil plans.

3. Several of the leaders of this conspiracy are now in prison and are awaiting the punishment worthy of their crimes.

4. When Catiline departed from the city he left here 
a large band formed from all (sorts of) criminals and placed Lentulus and Cethegus in charge of them.

5. It now remains for you to inflict punishment on these men and free us all from the fear of conspiracy.

6. You have already thanked me in extraordinary terms and have passed a resolution ${ }^{1}$ (stating) that by my noble conduct, (by) my efforts and foresight, the state has been freed from danger.

7. You have also forced Lentulus to resign from office and have decreed a thanksgiving in my honor. ${ }^{2}$

8. And not without reason have you done this, for this conspiracy has been spread ${ }^{3}$ more widely than people think.

9. Silanus is of the opinion ${ }^{4}$ that those who attempted to deprive us all of life ought not themselves to enjoy life.

10. There is indeed need of severity against Lentulus and the rest, for if the followers of Catiline lack leaders, the conspiracy can easily be crushed.

11. But if, on the other hand, ${ }^{5}$ we show ${ }^{6}$ leniency toward these leaders, we shall not perform our duty, and these men will get control of affairs.

12. The longer we delay, the greater will be the danger and the greater will be the number of men with whom we must contend.

13. The motion of Silanus seems to be a little more

1 " passed a resolution" =" decreed."

2 "in my honor" = "in my name."

3 "spread" = dissēminō, -āre.

4 "be of an opinion" = cēnseō or intellegō.

5 " on the other hand" = autem.

6 "show" = "use." 
severe than (that of) Caesar, but I shall show you that it is by far the more lenient.

14. No one is more mild than I, and in this case I am actuated ${ }^{1}$ not by cruelty of purpose, but by kindness.

15. Surely if we show leniency toward these men, we shall harm ourselves and the city; but if we punish them with death, we shall seem to show kindness toward ourselves.

675. Connected Prose:

At last, conscript fathers, we have driven from the city those men who were so ill disposed toward the state. You now see the city freed from plots, the state freed from danger, and yourselves rescued from the midst of death. Lentulus has resigned from office and together with the rest of the conspirators will be punished ${ }^{2}$ with a punishment worthy of his evil designs.

\section{EXERCISE FOR ORAL TRANSLATION}

1. Catiline has for a long time been abusing our patience.

2. You easily found men to free you from that care.

3. Unless these men desist from their crimes, they must be deprived of life.

4. All your plans are clearer to us than daylight.

5. That night a little before daybreak they came to me.

6. The Romans were braver than the Gauls. Translate in two ways.

7. Caesar's army was braver than (that) of Ariovistus. ${ }^{3}$

1 "actuate" = moveō. $\quad{ }^{2}$ afficiō. $\quad{ }^{3}$ Can this be translated in two ways ? 
8. This road is ten miles longer than that.

9. This road is much longer than that.

10. That scoundrel is unworthy of leniency and deserves death.

\section{LESSON XVIII}

\section{CONDITIONS IN INDIRECT DISCOURSE-DEPENDENT UNREAL CONDITIONS}

677. REFERENCES:

1. Conditions in Indirect Discourse : 351-356.

2. Dependent Unreal Conditions : 357-358.

\section{EXERCISE FOR WRITTEN TRANSLATION}

1. If this is true, senators, these conspirators ought to be killed. Cicero says that if this is true, these conspirators ought to be killed. Cicero said that if that was true, those conspirators ought to be killed.

2. If you decide to follow the advice of Caesar, you will give me a companion dear to the people. Cicero said that if they, etc. Cicero says that if they, etc.

3. If you should prefer to follow the opinion of Silanus, the latter would seem the more lenient. Cicero says that if they, etc. Cicero said that if they, etc.

4. Cicero says that if they had followed the advice of Caesar, the conspirators would have been sent out of the city. Cicero said that, etc.

5. Cicero asks whether he would have been cruel or kind-hearted if he had killed the conspirators. Cicero asked, etc.

6. Were these men good citizens they would not be trying to kill us all. Cicero says, etc. Cicero said, etc. 
7. If these men had been good citizens, they ought not to have been punished by death. Cicero says, etc. Cicero said, etc.

8. I myself think that if the leaders of this conspiracy should be killed, the conspiracy could easily be crushed. I myself thought, etc.

9. I myself think that if the leaders of this conspiracy are killed, the conspiracy will easily be crushed. I myself thought, etc.

10. If the leaders of this conspiracy had been killed, Cicero would have pardoned the rest. I believe that, etc. I believed that, etc.

11. I do not doubt that if the leaders of this conspiracy had been killed, Cicero would have pardoned the rest.

12. Even if I were not consul, I should try to punish these men with death. Cicero says, etc. Cicero said, etc.

13. If these men did these things, they deserve to be killed. I think that, etc. I thought that, etc.

14. If they were good citizens, they would not wish to destroy this city. I say that, etc. I said that, etc.

15. If these men had been good citizens, they would not have wished to destroy their native land. I say that, etc. I' said that, etc.

16. Transform each of the following sentences into indirect discourse: (a) after Cicerō dīcit; (b) after Cicerō dixit.
a. Sì hōc fēcerit, interficiētur.
b. Sì hōc feecisset, interfectus esset.
c. Sī hōc faceret, errāret.
d. Sì idōneus esset, cōnsul creandus erat. 


\section{LESSON XIX}

TEMPORAL CLAUSES: CUM-TEMPORAL - POSTQUAM, ETC.

679. REFERENCES :

1. Cum-Temporal Clauses : 277-282.

2. Clauses with Postquam, etc.: 283-284.

680. EXERCISE FOR WRITTEN TRANSLATION

1. When Pompey was in Asia, Catiline formed a conspiracy for the purpose of overthrowing the government.

2. After this first conspiracy had been suppressed, the conspirators attempted to bring it about that two of their own number be elected consuls.

3. When Catiline saw that Cicero had been elected, he thought that he ought no longer to hesitate to carry out his plans by violence.

4. Therefore he decided to secure the consulship on the following year and had planned to kill those who opposed him, when suddenly Cicero exposed all of his plans.

5. Whenever Catiline adopted plans for the killing of the leading men, Cicero (was) informed (and) prevented him from accomplishing what he attempted.

6. "When," said Cicero, "every one knows that these wicked men are trying to get control of the power in this state, Catiline will leave the city."

7. Accordingly, he considered it the consul's (duty) not only to oppose all Catiline's plans, but also to reveal everything to the people and senate.

8. On the eighteenth day after ${ }^{1}$ Cicero had revealed

1 When a definite interval of time is indicated, postquam is followed by the pluperfect. 
the plans of the conspirators, Catiline was still in the city and even dared to come into the senate.

9. Such audacity aroused Cicero's anger so that after he had revealed what Catiline had done during those eighteen days, he advised him to leave the city.

10. On the same day Catiline departed. His friends therefore said, "As soon as the cruel consul ordered poor Catiline to depart, he obeyed."

11. When Cicero learned that these things were being said, he delivered to the Quirites the second oration against Catiline.

12. After he had replied both to those who accused him of leniency and to those who accused him of cruelty, he spoke as follows :

13. "When you learn what classes of men have formed this conspiracy, you will be ashamed of having accused me of cruelty."

14. The third oration was delivered before the people, after the conspirators who remained in the city had confessed that they were sharers in Catiline's conspiracy.

15. After he had explained how their plans had been discovered, he tried to persuade the people that they had escaped in accordance with the good will of the immortal gods.

\section{Connected Prose:}

For after the citizens had been frightened by omens, they consulted men skilled in such affairs, who said that when a statue of Jupiter had been set up, the danger which was threatening the city would be averted. Accordingly, at the very time when the statue was being 
set up, the conspirators were being led to prison and the conspiracy was crushed.

\section{EXERCISE FOR ORAL TRANSLATION}

1. When the soldiers are in camp, they do not obey this centurion.

2. On the day when he was elected consul, his enemies tried to kill him.

3. When the enemy's army arrives, we shall have to stay inside the town.

4. Whenever the tribune of the soldiers heard shouting, he feared his own men.

5. Not only their letters but also the testimony of the Gauls show that they have done this.

6. He had often said that he had not done this, when suddenly he confessed.

7. When we were marching through Gaul, we crossed many rivers.

8. When we had arrived at the river Rhine, we pitched camp.

9. As soon as Catiline saw the danger, he burst forth from the city.

10. After he had finished this war, numerous messages were brought to him.

11. Scarcely had I said this, when he came.

12. When I am doing this. Use cum and translate in all tenses.

13. I saw him when he arrived. Use ubi. When he had come, we departed. Use cum.

14. On the fifth day after the general had come, we joined battle. 


\section{LESSON XX}

\section{TEMPORAL CLAUSES (Continued) - PROVISO}

683. REFERENCES:

1. Dum, while : 285-287.

2. Dum, until: 288.

3. Priusquam and Antequam : 289.

4. Proviso : 290 .

\section{EXERCISE FOR WRITTEN TRANSLATION}

1. While Cicero was delivering the first oration he said that it was inconsistent with his habits to refer to the senate (a question) concerning the punishment of the conspirators.

2. Nevertheless before doing ${ }^{1}$ anything concerning their punishment he called the senators together in order to ask their opinion on this very question.

3. Until Caesar offered a second proposal, all favored the proposal of Silanus, (which was) that the conspirators be punished with death.

4. "The Sempronian Law," said Caesar, "enjoins a magistrate from putting a Roman citizen to death until the people have assembled and decided that death is a just punishment."

5. While Cicero was speaking, he set forth both Caesar's and Silanus's proposals; but before he had finished speaking, he showed that he favored (that) of Silanus.

6. "The Sempronian Law," he said, "was indeed passed regarding Roman citizens, but no one can retain the rights of citizen provided he has not conducted himself as a citizen."

7. These conspirators seem to have been condemned 
ly you before you came to this meeting; no one hesitated . efore Caesar spoke just now.

8. However, after Caesar had finished speaking, a cer$t$ in senator went from this meeting before he should have t) express an opinion regarding the death of Roman citiz. $n$ ns.

9. But you who remain will decree death for these ren, provided you remember that we must now decide about men much more dangerous than the Gracchi.

10. After the senate had decreed death for Lentulus and his companions, Cicero put them to death at once kefore Catiline with his army could come to free them.

11. The many enemies whom Cicero had made in his consulship waited until they should be able to inflict on him some severe punishment.

12. Nor did they cease from their attempts and hopes until they had driven him into exile and even destroyed his home.

13. Cicero, while delivering his fourth oration, had said, "I will endure any fortune, provided only by my efforts safety is gained for the Roman people."

14. Before he was sent into exile, he had said that dangers of exile were to be considered of little importance.

15. But as long as he was in exile and could not see and hear what was going on in the city, he used to write sad letters to his friends in Rome.

\section{Connected Prose:}

While Cicero was consul he believed that all citizens of all classes except the conspirators themselves held one 
and the same opinion concerning the conspiracy. "As long as I shall live," he said, "people will remember that I have saved the state." However, even before he was driven into exile, people seemed to have forgotten this. But his enemies remembered well that he had put Roman citizens to death.

\section{EXERCISE FOR ORAL TRANSLATION}

1. Your consul will look out for your safety as long as he lives.

2. We can resist him, provided the good (people) hold the same opinion about him; ... provided they do not favor him.

3. With how great zeal people listened while Cicero spoke!

4. No one departed until he had finished speaking. ${ }^{1}$

5. Only one man left while he was speaking.

6. The rest remained until he should have finished speaking.

7. Cicero had learned all their plans before others knew that there was a conspiracy.

8. Cicero did not arrest the conspirators until Catiline had left Rome.

9. But he arrested the Gauls before they should bring those letters to Catiline.

10. The Nervii will draw up their line of battle before the Romans arrive.

11. They will then conceal themselves in the forest before they can be seen. 


\section{LESSON XXI}

\section{PARTICIPLES: ABLATIVE ABSOLUTE}

687. REFERENCES:

1. Tenses : 359-365. 3. As Adjectives : 366.

2. As Nouns : 367-368. 4. In Place of Clauses : 375.

5. Ablative Absolute : 369-374.

688. EXERCISE. FOR WRITTEN TRANSLATION

1. The Lex Papia, passed during the consulship of Cotta and Torquatus, provided that all men not enrolled as citizens should be expelled from Rome.

2. In accordance with this law a certain Gratius attempted to expel the poet Archias, who, though born in Antioch, had lived at Rome for many years.

3. Cicero, who had been taught by this Archias, took up his case and defended him in a speech delivered before his own brother, who was conducting the trial.

4. Cicero asked that in speaking in behalf of Archias he be permitted to employ an unusual style of speaking.

5. He said that if this permission was given, ${ }^{1}$ he would first prove that those attacking Archias were greatly mistaken, and then speak of the talent of Archias.

6. Archias, though born in Asia, was known to us for several years before he came to Rome in the consulship of Marius and Catulus.

7. He was here welcomed into the house of the Luculli, and was treated with the highest honor. by those who desired that their achievements should be praised. 
8. After a long interval had elapsed, ${ }^{1}$ he set out with Marcus Lucullus into Sicily, and thence to Heraclea.

9. At Heraclea he received many honors and was enrolled (as a citizen) in accordance with the law of Silvanus and Carbo.

10. Before (this) citizenship had been given (him), he had lived for many years in Rome; but since no part of the people was enrolled during the censorship of Caesar and Crassus, his name is not found on the records.

11. After the case had been thus stated, Cicero began to speak about the enjoyment resulting ${ }^{2}$ from the study of literature.

12. "Wise men," he said, "have not always been learned men; but all have taken great pleasure ${ }^{3}$ in the writings ${ }^{4}$ of poets.

13. Since the founding of the city there have been few poets who could surpass Archias in talent and learning.

14. If, therefore, you expel this man from the city, you will deprive us all of one of the greatest poets who have ever written of our achievements.

15. Not long since I saw Archias when he was speaking extemporaneously. On being encored ${ }^{5}$ he spoke on the same subject, but changed the wording. ${ }^{6}$ "

689. Connected Prose :

Caesar, removing the horses of all, addressed his men and began battle. The Romans, easily breaking up ${ }^{7}$ the phalanx of the enemy by hurling their javelins, drew

1 intermittō.

2 proficiscor.

8 "have been greatly pleased by."

4 "books." 6 "words."
5 "recalled." $\quad 7$ disiciōo.


their swords and made an attack on them. The enemy fled to the nearest mountain; but when they reached the mountain and our men were coming (up), the Boii and Tulingi attacked our men. The first and second lines of the Romans then resisted those (whom they had already) beaten, (and) the third line withstood those (who were) coming (against them).

\section{EXERCISE FOR ORAL TRANSLATION}

1. In my consulship. Under the leadership of Caesar. With the guidance of the immortal gods.

2. Now that this has been done. When this battle had been finished.

3. Eā rē permissā. Translate this in as many ways as you can.

4. After the bestowal of citizenship. After the burning of the city.

5. Caesar led forth his troops and drew them up in line of battle.

6. If Catiline had been killed, the state would not have been freed from danger. Translate the protasis in two ways.

7. Those who had been arrested were led to me.

8. Though there were (but) few defenders, the city could not be captured.

9. He summoned Labienus and put him in charge of the legions.

10. When they had investigated ${ }^{1}$ the case, they inflicted punishment on him. 


\section{LESSON XXII \\ EXPRESSIONS OF PLACE}

691. ReFERENCES:

1. Place Where : $186,189,191,194, a, 195-197$.

2. Place From Which : 188, 192, 194, $c, 195,198$.

3. Place To Which : 187, 190, 194, b, 195, 198.

692. EXERCISE FOR WRITTEN TRANSLATION

1. In the beginning of the oration in defense of Archias, Cicero told what city the poet was born in and in what parts of Greece he was known.

2. Archias was born of high station at Antioch, a populous city of Asia, and in that city he devoted himself to the study of literature.

3. The glory of his genius soon reached Greece and the Greek cities of Italy. Therefore when he came to Rhegium and Tarentum, he was presented with citizenship.

4. In Latium, and here at Rome, men so admired Archias that he was received into the homes of our greatest men.

5. After he had fixed his residence in the city of Rome, he went from Rome into Sicily, and from Sicily to the city of Heraclea, and there was presented with citizenship.

6. When he had returned from Heraclea to Rome, and was dwelling at his own home, he was enrolled as a Roman citizen.

7. Archias was a friend of Marcus Lucullus, and was often with him both at Rome and in many parts of Italy, and even lived at his house. 
8. Therefore Lucullus's enemies tried to expel Arshias from Rome, just as if he were not a Roman citizen, cor they said that he had never been enrolled at Heraclea.

9. When ambassadors from the city of Heraclea stated that Archias had been enrolled in that city, his enemies saw that they could not expel him from his home.

10. In all lands Cicero's speech for Archias is known, because in many parts of it he praised the study of literature.

11. "In all places," said Cicero, "the study of literature delights us, at home and abroad, in the city and in the country."

12. The glory of our armies is known in all parts of the world, because the exploits of our generals on land and sea have been praised by the poets.

13. When Archias was first coming toward Rome, we went to meet him, and received him into our city with great honor.

14. Are you now, jurors, going to expel from his home and the city of Rome this same poet whose (words of) praise of your generals are now read in all parts of Greece and Asia?

15. For Greek verses which he writes are read in all lands, while the Latin language is confined within its own narrow boundaries.

693. Connected Prose:

Why should we be living amid such great toils and dangers, $O$ jurors, if we did not look into the future ${ }^{1}$ 
and hope that our deeds would be extolled by the poets? I beg you, then, not to cast from his home my client, ${ }^{1}$ Archias, but to honor the name of poet, which among all races has always been held sacred.

\section{EXERCISE FOR ORAL TRANSLATION}

1. (1) At home; (2) at my own home; (3) on the ground; (4) in the country; (5) at Carthage ; (6) in Cures ; (7) in Mississippi ; (8) in Cincinnati ; (9) in Atlanta; (10) in Alabama; (11) in Syracuse ; (12) in Italy ; (13) in the city.

2. Express in Latin to the same places, except (3), mentioned above.

3. Express in Latin from the same places, except (3), mentioned above.

4. He went from the vicinity of Rome to the vicinity of Brundisium.

5. We have been conquered on land and sea. Let us not go from the city of Corinth. He has stationed soldiers in the city of Corinth.

6. Let us hasten to the town of Vesontio. Our enemies are in the vicinity of Vesontio.

7. He is famous at home and in war.

8. In many parts of the field bodies of the soldiers were seen. In these places there were many wounded soldiers.

9. In all Asia men feared Mithridates.

10. The enemy were fifteen miles distant from our camp. 


\section{LESSON XXIII}

\section{CAUSAL AND CONCESSIVE CLAUSES}

695. REFERENCES :

1. Causal Clauses : 291-297. 2. Concessive Clauses : 314-322.

\section{EXERCISE FOR WRITTEN TRANSLATION}

1. Cicero defended Archias because (as he said) he ${ }^{1}$ had taught him the art of speaking.

2. "For," said Cicero, "Archias, though he is a poet, can teach an orator, because all the arts which have to do with culture are connected with each other."

3. Although this trial was held in a public court, Cicero spoke freely concerning literary pursuits, because this style of speaking was suited to the defense of a poet.

4. First, however, he spoke on the case itself : "Archias was presented with citizenship by many Italian cities because they admired his genius."

5. Afterward, since he had now for many years had a home at Rome, he received Roman citizenship.

6. Archias, though he was a citizen of many other states of Italy, preferred to be called a Heraclean when he was being enrolled before the praetor.

7. Now Gratius, since ${ }^{2}$ he knows that the records of Heraclea have been burned, says that Archias was never presented with citizenship by the Heracleans.

8. However much, O Gratius, you may desire to persuade us that Archias is not legally a Roman citizen, you cannot make us believe you. 
9. For even though the records have been burned, ambassadors from that city say that Archias is a Heraclean.

10. Therefore you ought to admit that he is legally a Roman citizen, since you cannot deny that he had a residence at Rome and was enrolled before the praetor.

11. But granted that he were not already a Roman citizen, if you will hear me further, I will make you think he ought to be. ,

12. As every one knows, the greatest men have at all times honored the poets: (a) because by them their exploits are praised ; $(b)$ because by them their exploits were praised.

13. Alexander, although ${ }^{1}$ he was the greatest of all generals, is said to have called Achilles the most fortunate of all men in that his exploits were praised by Homer.

14. How many cities called Homer their (countryman) because he was a great poet! Shall we then drive Archias from the city in spite of the fact that he is legally our (citizen)?

15. Could not Archias have received citizenship through Metellus Pius, especially since he ${ }^{2}$ greatly desired his exploits to be written about?

\section{Connected Prose :}

This being the case, save Archias, O jurors ; for granting that he is only a Greek and not a Roman, it is better to rejoice that you have added a poet, though a foreigner, to the number of citizens than to grieve at having sent into exile unjustly one who is legally a citizen. Now since 
Irchias has really done what was demanded by the law of jilvanus and Carbo of those who wish to become Roman itizens, you jurors will surely not drive him from the ity, however much his enemies may demand it.

\section{EXERCISE FOR ORAL TRANSLATION}

1. Since his brother was conducting the trial, he spoke ather freely.

2. Although he left Rome of his own accord, his friends :omplain that the consul drove him out.

3. Lentulus, though he could have denied all this, nevertheless confessed.

4. He is worthy of great praise because he has saved the state.

5. However much you may beg for this, I will not give it to you.

6. Granted that this is true, yet they will not believe you.

7. Even though the general should order him to remain, he would depart.

8. These men, since they cannot be driven out, will remain at Rome.

9. The senate thanked him because he had saved Rome.

10. Though Antonius had been one of the conspirators, he was praised along with Cicero.

11. Even if he lives in Rome, he is not a citizen. Transform this into each of the six types of conditions and translate each.

12. Although he is calling me, I will not go. Translate, using: cum; quamquam; licet; quamvīs; etsī; ut. 


\section{LESSON XXIV}

\section{EXPRESSIONS AND CONSTRUCTIONS OF TIME}

699. REFERENCES :

1. Duration (Extent) of Time: 169. 3. Time Before and After Which :

2. Time When and Within Which : 173-174.

167-168, 170-172.

4. Dates : 175-185.

700. EXERCISE FOR WRITTEN TRANSLATION

1. Marcus Tullius Cicero was born January the third, 106 B.c. ${ }^{1}$ His friend Pompey was born in the same year, about nine months later, on September thirtieth.

2. In 66 B.c. $^{2}$ Cicero was elected praetor, and in that year delivered a speech on the Manilian law in favor of ${ }^{3}$ Pompey.

3. In 63 B.c., ${ }^{4}$ three years later, Catiline's conspiracy was brought to light, and within (the space of) thirty days Cicero delivered four orations against Catiline.

4. The first oration was delivered in the senate on the seventh of November. A few days before, on the twentyfirst of October, Cicero had warned the senate of this conspiracy.

5. Therefore the day of murder and burning had been postponed from the twenty-seventh of October to the twenty-eighth of October; but on that day they were not able to make a move against the state.

6. During the night, on the seventh of November, Catiline withdrew from the city, and during the whole night hastened toward the camp of Manlius.

1 Express the date from the founding of Rome.

2 Express in years before the birth of Christ.

8 prō.

4 Express by the names of the consuls, C. Antōnius and - 
7. On the following day, Cicero delivered the second s peech against Catiline before the people.

8. In this speech he warned Catiline's followers to del art, and told them that if they hurried, they could overtake him ${ }^{1}$ toward evening.

9. The third oration against Catiline was delivered lefore the people on December third, when Cicero informed the citizens (of) what had been done by the senate.

10. In the fourth oration, delivered in the senate on the fourth of December, Cicero spoke concerning the punishment of the conspirators who had been arrested by the praetors.

11. In the year after the suppression ${ }^{2}$ of this conspiracy, Cicero delivered his famous speech in behalf of his friend, Archias, the poet.

12. This man had come to the city of Rome during the consulship of Marius and Catulus, and had lived in the city for several years.

13. Since Archias had lived in Italy for several years, and had been enrolled (as a citizen) many years before in the city of Heraclea, Cicero easily defended him.

14. Four years later Cicero was driven into exile by his enemies, but in the following year he was recalled.

15. Caesar was assassinated March 15, 44 B.c., ${ }^{3}$ and in the following year Cicero was murdered December seventh.

\section{Connected Prose :}

In the year 58 в.c., Gaius Julius Caesar was chosen governor of Gaul and Illyricum, and in the first part of that year he set out for Gaul, where he remained eight

\footnotetext{
${ }^{1}$ Cf. $33 .{ }^{2}$ Cf. $368 .{ }^{3}$ Express in years before the birth of Christ.
} 
years. During that time he subjugated the tribes of Gaul, crossed the Rhine, and even transported his army into Britain. In 49 B.c., after he had spent eight years in Gaul, he returned into Italy to protect his interest against his enemies.

\section{EXERCISE FOR ORAL TRANSLATION}

1. On the tenth day. Within ten days. For ten days.

2. At daybreak. A little before daylight. From one P.M. till evening.

3. A little (while) ago. Ten days ago. Ten months after.

4. This man was killed in the Mithridatic war. In the memory of our fathers.

5. From March fourteenth to March twenty-eighth.

6. Give in Latin the calendar from October first to November first.

7. This morning between six and seven o'clock. Last night about nine o'clock.

8. On the arrival of Caesar a few days ago. During that summer.

9. On the appointed day. After the burning of the city.

10. During these (past) twenty years. At one time. Once upon a time.

\section{LESSON XXV}

703. EXERCISE FOR WRITTEN TRANSLATION

Although Cicero had had much experience in speaking before he delivered the oration for the Manilian law, 
avertheless this was the first speech delivered to the I oman people as a whole. For whatever power. he had (because of his ability) in speaking, all this up to this t me he had devoted to the trials of private citizens. 'hose plans of life entered upon in early manhood had ept him busy in this (kind of) effort, which, however, was ot without ample reward. For when he desired to be lected praetor, relying on the love of the Roman people, e gained his desire. This must be considered a great tribute to his ability, for his ancestors had not held any raagistracy at Rome.

On the day when he delivered this speech, the Roman people assembled in great numbers to hear him. Accordingly Cicero, remembering that (it was) the citizens (who) had bestowed upon him this honor, spoke for the cause of the people.

"It is a very great pleasure for me," he said, "to speak on this subject, for I have to speak of putting Pompey. in charge of the war with the king. You ought first to understand what is taking place in Asia. Two kings are making war on our allies, and at this very time Lucullus, our commander, after accomplishing much and leaving much (unaccomplished), is withdrawing from Asia. Under these circumstances we have to decide whether or not we ought to place in command of this great war our greatest general, Gnaeus Pompey."

\section{LESSON XXVI}

\section{EXERCISE FOR WRITTEN TRANSLATION}

That you may the better understand how deeply it concerns the welfare of all that this war be intrusted to a 
suitable commander, I shall first speak of the nature of the war.

Mithridates, who killed so many thousands of Roman citizens in one day, has now been reigning almost twentythree years, just as if he has never done us any harm. During all these years he has not tried to make us forget that crime, but has often harassed us with war. When we were waging war with Sertorius in Spain, Mithridates attacked us on land and sea, so that we, harassed by two enemies at one time, might have to fight for our supremacy. At that time Pompey crushed Sertorius's forces in Spain, but Lucullus triumphed over Mithridates in such a way that he, ${ }^{1}$ though defeated, still reigned. And so it has happened that Mithridates has not yet suffered any punishment worthy of his crime, but is now waging so oppressive a war on our provinces that our revenues, our property, and even the glory of our empire, are at stake. If Mithridates were threatening not your revenues, but only the safety of your allies, nevertheless you ought to consult their interests not only for their own sakes, but also for the sake of the dignity of the state.

Surely, then, this war is of such a character that you ought to wage it with the greatest zeal.

\section{LESSON XXVII}

\section{EXERCISE FOR WRITTEN TRANSLATION}

Mithridates is threatening all Asia so that not only Asia but even the cities in all Greece are in fear lest he may make an attack on them. Some one may say that the 
fears of our allies ought not to concern us; to these sen I should like to reply that it is a question not only ( $f$ the fear of our allies, but of our greatest revenues. For ' vho of you can deny that in the greatness of the tribute 'vhich she pays, Asia surpasses all lands? Perhaps you who live in Rome do not know that when a daring king vith an army is at hand, men do not till those fields. in which they fear that an army will soon encamp, and that nerchants and sailors do not set sail when there is danger that they may meet on the sea ships full of hostile soldiers.

And so it happens that the mere fear of an attack often diminishes the gains of those who live in the provinces, and this cannot happen without ${ }^{1}$ our revenues being diminished at the same time.

All men of all classes both here at Rome and in Asia, whose interests are at stake, have the same feeling as you, that Pompey, by whose mere approach the king's attacks were checked, ought to be chosen as the general for this war.

\section{LESSON XXVIII}

\section{EXERCISE FOR WRITTEN TRANSLATION}

In that war which Sertorius in Spain and Mithridates in Asia were at one time waging with us, Pompey crushed the forces in Spain. You have heard also how Lucullus destroyed Mithridates's fleet, freed the cities which he (Mithridates) was besieging, captured the cities in which the royal residences were, deprived the king himself of 
his ancestral kingdom, and made him flee as a suppliant to other nations. But he did not capture Mithridates himself, and that is why ${ }^{1}$ we must again wage war with that same king. For Mithridates, knowing that Roman citizens are now more greedy for booty than desirous of honor and glory, in his flight left a great quantity of gold and silver and beautiful objects for our soldiers to collect. Then that happened which Mithridates had hoped would happen, for the soldiers preferred to collect the gold and silver rather than to pursue the escaping king. After Mithridates had slipped from our hands, he was assisted both by those who feared and hated us and those who pitied him. Soon he was able to return to the kingdom from which he had been driven, and then reinforcements from many nations enabled ${ }^{2}$ him to attack and overwhelm our army. At this crisis, Lucullus was recalled to Rome because, according to ancient precedent, he had held command too long, and the army was handed over to Glabrio, though he was unworthy that such important affairs be intrusted to him.

\section{LESSON XXIX}

\section{EXERCISE FOR WRITTEN TRANSLATION}

Since I am now going to speak of the choice of a commander for this war, (it is) about the distinguished ability of a certain general (that) I shall have to speak. I would that we had so many great generals that it would be difficult for you to know which general I am going to speak about. But since Pompey is the only one whom all our enemies fear, since he is not far distant from those 
'egions, and since he is the equal of the generals of ancient times, ${ }^{1}$ does any one doubt that he should be put in charge of this war? For he alone possesses in the highest degree all (those qualities) which a great general ought to possess. (While) still a boy he was a soldier in a great war, in his early manhood both a general and a conqueror, and from that time up to the present ${ }^{2}$ day every kind of war on land and sea he has engaged in and brought to a finish - a thing which our generals in Asia seem to have been unable to do.

It remains for me to speak of the war which he recently waged against the pirates. You can better understand how great relief he has brought to all of us if you recall in what great danger we were on account of the pirates before Pompey was placed in charge of our army and fleet. Less than a year ago not even our praetors could set sail without being captured, but within these few months so great a change has Pompey brought about that no pirate can now be found on the whole sea.

\section{LESSON XXX}

\section{EXERCISE FOR WRITTEN TRANSLATION}

A great general should possess many exceptional qualities and should be a man of the greatest integrity, honesty, and self-restraint. All these qualities Pompey. possesses (in the) highest (degree), (a fact) which can easily be understood if we compare him with all the other generals whom we have ever seen or heard of. For many of our generals, because of their greed, have done more harm to our allies than to the enemy, and have destroyed

1 "of ancient times" = vetus.

2 "the present" = hic. 
more cities of our friends than of those against whom they were sent. Pompey, on the other hand, has always acted with the greatest self-restraint and has never permitted his soldiers to do the slightest ${ }^{1}$ harm to our allies. Those things which have often called others aside from their duty, Pompey disregarded, and no city of our allies was ever plundered by his army. Now our allies can understand why their ancestors not unwillingly served the Roman people; and daily dispatches are being brought to Rome, (telling) how the people in Asia regard Pompey. You yourselves know that Pompey is a man of the greatest courage, honor, and culture, and that he is feared by the enemy and loved by all our allies. Shall we then, mindful of these things, hesitate to place him in charge of this war in Asia and to intrust the fortunes of our allies to him, especially when we know that he is the only man whom our allies demand?

\section{LESSON XXXI}

\section{EXERCISE FOR WRITTEN TRANSLATION}

No one can doubt that in prestige Pompey excels all other generals of the present day, ${ }^{2}$ and we all know that in conducting wars a general's prestige is of very great importance. For it has often happened that men were moved to hate or love, or to despise or fear, a general because of his reputation alone. Last year Pompey was put in charge of the war which we were waging with the pirates, and there is no doubt that if he had not been in Asia at that time, you would have lost that province.

\footnotetext{
1 "slightest" = quicquam.

2 " of the present day" = "of those who now are."
} 
It that time ambassadors were sent to Pompey to say hat they wished to surrender all the states of the Cretans 10 him, and from this, fellow-citizens, you can judge low much weight this man's prestige has among foreign nations.

Now let me say a few (words) about his success, for 1 his quality also should be sought for in a great general. $t$ is needless to recount the various wars which Pompey has successfully waged on land and sea, for his achievements are so numerous that they seem to have been granted to him by the immortal gods. Therefore, since this man possesses all the qualities which should be found in a great general, why do we hesitate to put him in charge of this war? For even if Pompey were not already in Asia and did not have an army (there), still he ought to be chosen as general for this war.

\section{LESSON XXXII}

\section{EXERCISE FOR WRITTEN TRANSLATION}

Quintus Catulus, a very patriotic man, and Quintus Hortensius, (a man) endowed with the greatest ability and talent, are trying to prevent us from putting Pompey in charge of this war in Asia, and in the past their authority has on many occasions ${ }^{1}$ had great influence with you. But in this case you ought not to be persuaded by these men, for last year these same men attempted to persuade you not to appoint Pompey for the war which we were waging with the pirates; and if you had followed their advice then, all of our provinces would now be in the

1 "on many occasions " = "(in) many places." 
power of the pirates. These men grant that all that I have said is true; (namely,) that the war is a very great one, that it must be waged with the utmost energy, and that Pompey is the only man fit to be placed in command of the armies of the Roman people. But they say that all (power) ought not to be conferred on one man. Pompey, in defeating ${ }^{1}$ the pirates with so great success, has shown that they were mistaken in that statement. Before he was put in charge of that war, we were no match for the pirates and were being deprived by them not only of our provinces, but even of our sea coast and harbors. When Pompey has accomplished so much in the war which he waged against the pirates, can any one doubt that he will be able to conduct the war with the king with as great success?

\section{LESSON XXXIII}

\section{EXERCISE FOR WRITTEN TRANSLATION}

No one of us doubts, Hortensius, that at that time you spoke with good intention; but now that we have seen that, under the Gabinian law, in one year and by one man, we were all saved from the pirates, we cannot be persuaded to follow your advice. Nor can you persuade us that Aulus Gabinius ought not to be sent as Pompey's lieutenant, for he, by whose law we were saved from the pirates, surely ought to be a sharer in the glory of the general who, in accordance with his law, freed us all from danger.

It remains for me to speak of the authority of Quintus Catulus, which I value very highly. He thinks that all

1 Use a relative clause. 
'powers) ought not be conferred on one man. But in his case I believe that he is greatly mistaken, for I think hat the greater a man is, the more the state ought to enjoy (the advantage of) his life and ability. Yet Catulus says that we should not do anything contrary to the preczdents of our ancestors and advises that no new measures ${ }^{1}$ be adopted. But on many occasions the Roman people has conferred supreme power on one man, and even in the case of Gnaeus Pompey many new (measures) have already been adopted. Nor is it necessary to say that on every occasion he has acted with the utmost integrity and selfrestraint.

\section{LESSON XXXIV}

\section{EXERCISE FOR WRITTEN TRANSLATION}

In the war which we are now waging we must choose a general who not only possesses military ability, but who can also conduct himself with uprightness and honor. For the generals whom we have sent to defend our allies during the past years have through their greed harmed our allies more than they have protected (them), and in all Asia there is not a single state which has not been plundered by our generals and armies. Therefore unless we can choose a general who can prevent the cities of our allies from being plundered by his own soldiers, he will not be a suitable man to be sent. Shall we then hesitate to confer all (powers) on Gnaeus Pompey, who is the only man to be found who is loved by all the allies and feared by all our enemies?

If it is a question of authorities, we have many men of 
prominence as the sponsors of this law, and we can oppose the authorities of these men to the arguments of Catulus and Hortensius.

Therefore, Gaius Manilius, I urge you to abide by your motion and not to be deterred by threats of force from demanding that Gnaeus Pompey be put in charge of this war. And whatever talent I possess, I will gladly employ in aiding you and your law. Nor am I influenced to do this through any desire for Pompey's favor ; for whatsoever I have said in this case I assure you I have said because I believe that it is to the best interests of the Roman people to send Pompey to this war.

\section{LESSON XXXV}

\section{EXERCISE FOR WRITTEN TRANSLATION}

(Explanation: One of the Roman legions had been surprised by an ambuscade. The enemy who outnumbered the Romans were fighting with unusual skill and bravery.)

Titurius alarmed by these things and seeing Ambiorix at a distance encouraging his men, sent a messenger to him to ask him to spare himself and his soldiers. $\mathrm{He}$ (Ambiorix) replied that if he wished to confer with him, he might do so. He hoped that he could prevail upon the multitude to spare the soldiers; he himself (Titurius) would not be harmed at all, to this he pledged his word. Sabinus accordingly ordered what military tribunes he had about him, and the centurions of the first rank, to follow him, and when he came nearer to Ambiorix, on being ordered to lay down his arms, he carried out the command and ordered his men to do the same. Meanwhile, while they were treating with each other about terms, Titurius 
Ind the centurions and tribunes were surrounded and silled. Then the Gauls, as was their custom, shouted victory and making a sharp attack on our men threw he ranks into confusion. When Cotta and a large part of the soldiers had fallen, the rest retreated to the camp from which they had gone forth. With difficulty did they sustain the attack until night. On that night, despairing of safety, they all killed themselves. A few who had escaped from the battle before Titurius had been killed, went through the forests to the winter quarters of Labienus and informed him of what had happened.

Ambiorix, elated by this victory; set out with his cavalry to (the territory of) the Nervii and his other neighbors to persuade them not to neglect this opportunity of freeing themselves forever and of taking vengeance on the Romans for all the injuries which they had received. The Nervii were easily persuaded to adopt this plan, and so it happened that since one legion had been destroyed, within a few days the winter quarters of the other legions were attacked by the Gauls.

\section{LESSON XXXVI}

\section{EXERCISE FOR WRITTEN TRANSLATION}

In many parts of Gaul there was a rumor that Caesar could not come to the army on account of the disturbances in Rome. The Gauls, who had for some time been deploring (the fact) that they had been subjected to the sway of the Roman people, were influenced by this rumor to come together to a conference and adopt plans for war. They decided to prepare for war so quickly as to shut 
Caesar off from his army. For they believed that the legions would not dare to leave their winter quarters in the absence of their commander, and that Caesar could not reach his legions without a very strong guard. Finally they said that it was better to be killed in battle than not to get back their former liberty, which they had received from their ancestors.

When Caesar was informed of this, he at once set out for Gaul; but when he had arrived there, he was in great doubt (as to) whether ${ }^{1}$ he should summon his legions to him or himself go to his legions. Meanwhile the leaders of the conspiracy had persuaded new states to join them. On receipt of this news, Caesar decided that it was of the greatest importance that he should come to his legions. Accordingly, he set out at once with a small force, and by forced marches arrived among the Arverni, whom he easily crushed, since they had thought that no one could cross the mountains and reach them at that time of year. The Arverni at once sent messengers to the Gallic leader, Vercingetorix, to ask him that he should not permit their lands to be laid waste by so small a band of Romans. Vercingetorix decided to come with all his forces to help the Arverni, while Caesar hastened to lead from winter quarters all his legions and to collect them into one place. And so, though the winter was not yet completed, both the forces of the Gauls and the legions of the Romans were being assembled for the great war which was to-be-waged the next summer.

${ }^{1}$ Affirmative verbs and expressions of doubt may be followed by an indirect question introduced by an. 


\section{LESSON XXXVII}

\section{EXERCISE FOR WRITTEN TRANSLATION}

Put the following into indirect discourse after Ambiorix i.d hunc modum locūtus est :

I confess that $I$ owe much to Caesar in return for his rindness to me, because (it was) by his help (that) I was reed from the taxes which I had been in the habit of payng to my neighbors, and because both my son and my orother's son, whom the Aduatuci kept with them in slavery, have been returned to me by Caesar. That which I did concerning the storming of the Roman camp I did, not according to my own judgment and desire, but at the command of the state. My power is such that the people have no less control over me than I have over the people. So far as the state is concerned, ${ }^{1}$ the cause of the war is that they could not hold-out-against a sudden conspiracy. I am not so ignorant as to think that the Roman people can be subdued by my forces, but all Gaul has a fixed plan (of action); this day has been set for attacking all Caesar's winter quarters, so that no legion may be able to come as reinforcement to another legion. Gauls cannot easily refuse Gauls, ${ }^{2}$ especially when a plan regarding the liberty of all seems to have been adopted. Since by attacking the Roman camp I have done my duty for the Gauls, I now remember Caesar's kindness. And so I warn the Roman legatus to look out for his own safety and that of his legion; to lead his troops out of winter quarters and to take them either to Cicero or Labienus, one of whom is

1 "so far... concerned," express by using the dative of civitās. Cf. 87.

2 Cf. 78. 
about fifty miles away, the other a little farther. I promise to grant a safe journey through my territory. In that I am giving the Romans this warning I am both looking out for my own state and returning thanks to Caesar and the Romans for their services.

\section{LESSON XXXVIII}

\section{EXERCISE FOR WRITTEN TRANSLATION}

(EXPlanation: The army of Caesar, commanded by Curio, and the army of Pompey, commanded by Attius, were drawn up on opposite sides of a valley. On the previous day Curio had addressed his soldiers and had rebuked them for the spirit of fear and mutiny which he had observed among them. They had been greatly moved by his words, and had promised to obey without question whenever he might order them to fight.)

Between the two lines, as I have said above, was a valley, not so (very) large, but the ascent (from it) was very difficult. ${ }^{1}$ Each leader waited (to see) whether ${ }^{2}$ the forces of the enemy would try to cross it, in order that he might begin battle in a more favorable position. Soon all the cavalry of Attius on the left wing, and along with them many light-armed soldiers, were observed descending into the valley. Against these Curio sent his cavalry and two cohorts of infantry. The cavalry of the enemy did not hold-out-against the first attack of these troops, but fled back to their comrades with their horses at full speed, (and) the light-armed soldiers, abandoned by those who had run forward with them, ${ }^{3}$ were surrounded and killed by Curio's forces. The whole line of Attius, looking

1 " but . . . difficult," express by using an ablative of description.

${ }^{2}$ Cf. page 294 , footnote.

${ }^{3}$ Express by the adverb ūnā. 
ack, saw their men fleeing and being killed. Then a ;ertain legatus of Caesar whom Curio had taken with him 'rom Sicily, because he knew that he had much experience n war, said, "You observe that the enemy is thoroughly rightened, Curio; why do you hesitate to use your opporjunity?"

Curio, ${ }^{1}$ after urging the soldiers to remember what they aad promised him on the preceding day, ordered them to follow him, and ran forward before all. The sides of the valley were so steep that in the ascent the first could not go forward except when assisted by their comrades. But the soldiers of Attius, terrified by the flight and slaughter of their comrades, did not think about resisting, and all believed that they were being surrounded by the cavalry. And so, before a weapon could be hurled or our soldiers could come nearer, all Attius's line turned and retreated to camp.

\section{LESSON XXXIX}

\section{EXERCISE FOR WRITTEN TRANSLATION}

(Explanation: Murena, the consul elect, is being tried for having employed bribery at the elections when he was chosen consul. During the trial he is also charged with having devoted himself to pleasure instead of duty when in charge of the war with Mithridates. Cicero replies to this charge.)

Cato says that my client, Murena, devoted himself to pleasure and luxury while he was in command of our army in Asia. I should like to say that a general cannot devote himself to pleasure without being defeated, unless 
the enemy is (such as) to be despised. We all know that Murena was not defeated. It remains for us to consider whether Mithridates was an enemy to be despised. This I assert: If this war, if this enemy, if that king, had been (such as) to be despised, the senate and the Roman people would not have thought that the war ought to be undertaken, nor would Lucullus have waged it for so many years with so much glory, nor would the Roman people with such zeal have intrusted the task of finishing it to Pompey.

Of all Pompey's battles that which he fought with the king seems to have been the most severe. When he ${ }^{1}$ had escaped from this battle and fled to the Bosporus, where our army could not go, even in this extremity he still retained the name of king. And so when Pompey had seized the kingdom and expelled the enemy from all his well-known dwelling places, and because of his victory was in possession of everything, yet he did not consider the war finished until he had deprived him ${ }^{1}$ of life. Do you, then, jurors, despise this enemy whom so many generals have waged war with for so many years - (an enemy) whose life, (even) when he was defeated and exiled, was considered of such moment that ${ }^{2}$ only upon the announcement of his death was the war considered finished?

Can any one, then, believe that Murena, who waged war with so great an enemy without being defeated, was at the same time devoting himself to pleasure rather than duty?

\section{Mithridates.}

2 "'that, his death having been announced, the war.was finally considered finished." 


\section{LESSON XL}

\section{EXERCISE FOR WRITTEN TRANSLATION}

(Explanation: Murena, one of the consuls elected t. succeed Cicero, was accused of having secured his elecon by bribery. If convicted, he could not enter on the luties of consulship on January first. ${ }^{1}$ Cicero, who was (: $)$ nsul at the time of the trial, defended Murena. During his speech he made the point that it would be unwise to (2xclude from the consulship a general of so much experience as Murena, when a great conspiracy was on foot. ${ }^{2}$ )

In this crisis of the state it is of the greatest importance that there should be two consuls on the first of January. T.wo have been elected, but you, who are accusing my client, are trying to deprive the state of one of them. Do you not see, Cato, that this is the very thing that Catiline and the conspirators desire? Do you not see the danger? All the evils which have been stirred up throughout these three years, from that time when the plan of killing the senate was adopted by Catiline, are bursting forth in ${ }^{3}$ these days (and) in this time. What place is there, jurors, what time, what day, what night, when I am not being rescued from the swords of these men, not by my foresight, but by the wisdom of the gods? Those conspirators do not desire to kill me on my own account, but to remove a diligent consul from his guardianship of the state. Not less, Cato, would they like to make way with you, a diligent tribune, if they could - a thing

1 On January first the newly elected consuls were inaugurated.

2 This speech was delivered in December of the year of Cicero's consulship, before the fear aroused by Catiline's conspiracy had subsided.

3 " into." 
which they are now plotting and setting about. They see how much protection to the state there is in you. They believe that if you are deprived of the aid of the consul, they will then more easily crush you when thus unarmed and weakened. For they do not fear that, if Murena is expelled from the consulship, any one will be chosen in his place. They hope that Silanus ${ }^{1}$ without a colleague, and you without a consul, and the republic without protection, can be destroyed.

In the midst of perils so great as these 2 it is your duty, Cato, since you were not born for yourself but for your country, to observe what is going on, to keep as a defender, as an ally in the republic, my client, Murena, a consul experienced in military affairs, a consul who can defend us from the attacks of these conspirators.

1 Silanus, along with Murena, was one of the consuls elect.

2 "so great as these" = " these so great." 


\section{SPECIAL VOCABULARIES}

\section{PART III}

\section{LESSON I}

Learn carefully the word list n 3. ıddūcō, -dūcere, -dūxī, -ductum, lead on, induce, influence. auctōritās, -tātis, f., influence, prestige.

causa, -ae, f., cause, case; causam

dīcō, plead a cause, plead a case. cōgō, -ere, coēgī, coāctum, collect, gather; force, compel.

commoveō, -ēre, -mōvī, -mōtum, move, alarm, disturb.

coniūrātiō, -ōnis, f., conspiracy; coniūrātiōnem faciō, form a conspiracy.

cōnstituō, -ere, -stituĩ, -stitūtum, establish, determine, appoint, fix.

contineō, -ēre, -tinuī, -tentum, hold in, hem in, bound.

èripiō, ere, -ripuī, -reptum, snatch away, rescue.

fidēs, fideī, f., promise, pledge, faith; fidès et iūs iūrandum, oath-bound pledge.

fīnis, fīnis, m., end, boundary; fīnēs, fīnium, m. pl., territory, country.

incolō, -ere, -coluī, - inhabit, live, dwell (in), with acc. inter nōs damus, inter vōs datis, etc., we (you, etc.) interchange, exchange.

iūdicium, iūdicī, n., trial, judgment. mulier, mulieris, f., woman.

parătus, -a, -um (p. p. of parō), prepared, ready; parātus ad . . ., ready for . . .

pars, partis, f., part, direction.

rēgnum, -ī, n., kingdom, royal power, throne.

vehementer (adv.), greatly, strongly, exceedingly, very, severely.

vinculum, $-\overline{1}, \mathrm{n} .$, bond, chain; ex vinculis, in chains.

\section{LESSON II}

agō, -ere, ēgī, āctum, drive; do, act; treat, discuss.

castra, -ōrum, n. pl., camp; castra pōnō, pitch camp; castra moveō, break camp.

cōnor, -ārī, -ātus sum, try, attempt. cōnsuēscō, -ere, -suēvī, ssuētum, become accustomed; in the perfect system, be accustomed, be used. Cf. 209-210.

interclūdō, -ere, -clūsī, -clūsum, block, cut off, shut off. ita (adv.), thus, so; as follows. iter, itineris, n., way, road, route, passage. 
maneō, -ēre, mānsī, mānsūrus, remain, stay, abide.

memoria, -ae,f., memory; memoriā teneō, remember. (memoriā, abl. of means.)

mūnītiō, -ōnis, f., fortification. perveniō, -īre, -vēnī, -ventum, arrive; . . . ad . . ., reach.

posterus, -a, -um, following. prīmus, -a, -um, adj., first; prīmō, adv., first; primum, adv., at first, in the first place.

pristinus, -a, -um, former, of olden time.

prohibeō, -ēre, -hibuī, -hibitum, prevent, keep off, keep out.

satisfaciō, -ere, -fēcī, -factum, make amends, render satisfaction.

vāstō, -āre, -āvī, -ātum, devastate, lay waste, ravage.

\section{LESSON III}

Learn carefully the lists of words in 70,72 .

apertus, -a, -um, open.

campus, $-\overline{1}, \mathrm{~m} .$, plain, level ground. cēlō; -āre, -āvī, -ātum, conceal, hide. Cf. 70 .

certus, -a, -um, determined, fixed, certain; certiōrem faciō, inform; certior fīo, be informed.

circumdō, -are, -dedī, -datum, surround, place around. circumveniō, -ïre, -vēnī, -ventum, surround, gather around. Cf. 62 . explōrātor, -tōris, m., scout.

instruō, -ere, -strūxī, -structum, draw up, array, build.

mille (indecl. adj.), a thousand; mĩlia, mīlium, n. pl., thousands. moneō, -ēre, monuī, monitum, warn, advise.

passus, -ūs, m., a pace; mille passūs, $a$ (Roman) mile; mîlia passuum, (Roman) miles. polliceor, -èrī, pollicitus sum, promise.

potēns, potentis, powerful.

plūs possum (valeō), be more powerful. Study carefully 66 . quaerō, -ere, quaesīvĩ, quaesītum, ask (for), seek. Cf. 70-72.

respondeō, -ēre, -spondī, -spōnsum, answer, reply.

retineō, -ēre, -tinuī, -tentum, hold back, keep, retain.

rogō, -āre, -āvī, -ātum, ask (for) beg. Cf. 70-72.

sentiō, -īre, sēnsī, sēnsum, know, think, entertain an opinion.

sub (prep.) with acc., to the foot of; with abl., at the foot of.

summus, -a, -um, highest, top of. Cf. 108.

tandem (adv.), finally, at last.

\section{LESSON IV}

Learn carefully the list of words in 221.

centūriō, -ōnis, m., centurion.

concilium, concili, n., meeting, council.

cornū, -ūs, n., horn, wing (of an army); à dextrō cornū, on the right wing; à sinistrō cornū, on the left wing.

crūdēlitās, -tātis, f., cruelty.

dēligō, -ere, -lēgī, -lēctum, choose, select.

dolus, -ī, m., trickery, strategy, cunning. 
f .llō, -ere, fefellī, falsum, de-|cōnsequor, -sequī, -secūtus sum, ceive, trick.

$g$ znus, generis, n., race, nation, tribe.

i nperō, -āre, -āvī, -ātum, command, rule. Cf. 79-82.

1 )quor, loquī, locūtus sum, speak, talk, say.

r.ūntius, nūntī, m., messenger, message, report.

( fficium, officī, n., duty, sense of duty, loyalty.

l'atior, patī, passus sum, permit, allow, suffer, endure.

praecipiō, -ere, -cēpī, -ceptum, direct, instruct, order.

proelium, proelī, n., battle; proelium committō, begin battle, join battle.

quotiēns, how many times? how often?

redintegrō, -āre, -āvī, -ātum, renew. redūcō, -ere, -dūxī, -ductum, lead back.

quō modō, how? Used especially to modify verbs.

quam, how? Used especially to modify adjectives and adverbs.

\section{LESSON V}

Learn carefully the list of words in 263.

ācer, ācris, ācre, fierce, sharp, eager, keen.

arcessō, -ere, -īvī, -ìtum, summon, send for.

barbarus, -a, -um, barbarous. colloquium, colloquī, n., conference.

commeātus, -ūs, m., supplies. Commonly used in the singular. overtake.

crūdēlis, -e, cruel.

effugiō, -ere, -fūgī, -fugitum, escape, flee.

fīnitimus, -a, -um, neighboring, next; fīnitimī, -ōrum, m. pl., neighbors.

inferō, -ferre, intulī, inlātum (illātum), inflict, bring upon. obiciō, -ere, -iēci, -iectum, expose. reddō, -ere, reddidī, redditum, return, give back.

redeō, -īre, -ī̄, -itum, return, go back.

revertor, revertī, revertī or reversus sum, reversum, return, go back, come back.

reiciō, -ere, -iēcī, -iectum, hurl back, throw back.

statim (adv.), at once, immediately, straightway.

sustineō, -ēre, -tinuī, -tentum, withstand, sustain.

tūtus, -a, -um, safe; tūtō, adv., safely.

vigilia, -ae, f., watch. Cf. 175.

\section{LESSON VI}

Learn carefully the list of words in 81.

appropinquō , -āre, -āvī, -ātum, approach, draw near.

comparō, -āre, -āvī, -ātum, prepare, raise (an army).

complūrēs, complūra (complūria), several.

imperium, imperī, n., control, command, rule.

inquam, I say; inquit, he says; inquiunt, they say. Cf, 412,3 . 
lūx, lūcis, f., daylight; prīmã lūce, at daybreak.

māgnopere (adv.), greatly, much, very.

novae rēs, novārum rērum, f. pl., nova imperia, novōrum imperiōrum, n. pl., a revolution, a change of government.

oppūgnātiō, -ōnis, f., siege, attack. perterreō, -ēre, -terruī, -territum, alarm, disturb. petō; -ere, -īvì, -ïtum, seek, sue for, ask for.

profectiō, -ōnis, f., departure, $a$ setting out. tumultus, -ūs, m., disorder, disturbance.

ūsus, -ūs, m., use, advantage. ùtilis, -e, useful, advantageous.

\section{LESSON VII}

Learn carefully the lists of words in $275,1-4$.

coniungō, -ere, -iūnxī, -iūnctum, join.

cōnspiciō, -ere, -spēxī, -spectum, see, catch sight of.

cotīdiē (adv.), each day, daily. dignus, -a, -um, worthy. Cf. 145, 275.

dubitō, -āre, -āvī, -ātum, hesitate; doubt. Cf. 272-273.

fuga, -ae, f., flight, escape; in fugam dō, put to flight. idōneus, -a, -um, suitable, fit. Cf. $92,275$.

impediō, -ïre, -īvī, -ītum, prevent, hinder. Cf. 269-270.

dēterreō, -ēre, -terruī, -territum, prevent, deter. Cf. 269-270. prohibeō, -ēre, -uī, -itum, prevent. Cf. 271.

metuō, -ere, metuĩ, - fear, be afraid. Cf. 266-268.

timeō, -ēre, -ū̄, -itum, fear, be afraid. Cf. 266-268.

vereor, -ērī, veritus sum, fear, be afraid. Cf. 266-268.

metus, -ūs, m., fear.

timor, -ōris, m., fear.

mūniō, -īre, -īvì, -ìtum, fortify.

nē . . . quidem with the emphatic

word between, not even.

prōgredior, prōgredī, prōgressus sum, advance, proceed.

recūsō, -āre, -āvī, -ātum, refuse.

Cf. 269-270.

repellō, -ere, reppulī, repulsum, drive back.

sequor, sequī, secūtus sum, follow, pursue.

\section{LESSON VIII}

Learn carefully the list of words in 382 .

aedificō, -āre, -āvī, -ātum, build. collocō, -āre, -āvī, -ātum, station, place.

cōnficiō, -ere, -fēcī, -fectum, accomplish, finish.

cōnfectus, -a, -um; exhausted, worn out.

cōnsilium, cōnsilī, n., plan; cōnsilium capiō, adopt a plan. cūrō, -āre, -āvī, -ātum, care for, arrange, attend to. Cf. 382 .

dēdō, -ere, dēdidī, dēditum, give up, surrender. The object must be expressed.

discēdō, -ere, -cessī, -cessum, withdraw, depart. 
acultās, -tātis, f., chance, opportunity.

atrā (prep. with acc.), inside, within.

ıāvālis, -e, naval.

ıāvigō, -āre, -āvī, -ātum, navigate, sail.

sfferō, offerre, obtulī, oblātum, offer.

spprimō, -ere, -pressī, -pressum, crush.

palūs, palūdis, f., marsh, swamp.

prope (adv. and prep. with acc.), near, nearly, almost.

prōvideō, -ēre, -vīdī, -vīsum, look after, look out for. Cf. 382.

recipiō, -ere, -cēpī, -ceptum, take back, recover; mē recipiō, I retreat, retire.

relinquō, -ere, -līquī, -lictum, leave, abandon.

rēs frūmentāria, reī frūmentāriae,

f., grain supply.

\section{LESSON ix}

Learn the list of words in 109.

aliēnus -a, -um, of another, of others, another's, others'.

98.

āmentia, -ae, f., madness. armō, -āre, -āvī, -ātum, arm; armātus, -a, -um, armed. circiter (adv.), about. $\left.\begin{array}{l}\text { cōnsuētūdō, -dinis, f., } \\ \text { mōs, mōris, m., }\end{array}\right\}$ custom. cotīdiānus, -a, -um, daily.

dēfendō, -ere, -fendī, -fēnsum, defend, protect.

tueor, tuērī, (tūtus sum), defend, protect, watch, guard. dēleō, -ēre, -ēvī, -ètum, destroy. exercitātiō, -ōnis, f., training, practice, experience.

inferō, -ferre, intulī, inlātum (illātum), bring in, import.

importō, -āre, -āvī, -ātum, bring in, import.

iterum (adv.), again, a second time. rūrsus (adv.), again, back again. lacessō, -ere, -īvī, -ìtum, harass, attack.

longē (adv.), by far, far.

negōtium, negōtī, n., business, task, undertaking.

quotannis (adv.), yearly, every year.

\section{LESSON $X$}

Learn carefully the lists of words in 117, 118, 122.

accūsō, -āre, -āvī, -ātum, accuse,

blame, charge. Cf. 121.

admoneō, -ēre, -uī, -itum, warn,

remind. Cf. 117.

causa, -ae, f., cause, case, reason. damnō, -āre, -āvī, -ātum, condemn.

Cf. 121.

dēditiō, -ōnis, f., surrender.

ègredior, ēgredī, ēgressus sum, go forth; (nāvī) ēgredior, disembark. exīstimō, -āre, -āvī, -ātum, consider, think.

dūcō, -ere, dūxī, ductum, lead; consider.

factum, -ī, n., act, deed.

interest, interesse, interfuit, it is to the interest (advantage) of. Cf. 124-125.

lïtus, littoris, n., shore.

memini, remember. Cf. 116 and 209. 
miseret, miserēre, miseruit, it pities. Cf. 118.

$\operatorname{mox}(\mathrm{adv}$.$) ,$ brevi tempore, soon.

oblivisiscor, oblīvīscī, oblītus sum, forget. Cf. 116.

paenitet, paenitēre, paenituit, it repents, it regrets. Cf. 118.

portus, -ūs, m., harbor. pudet, pudēre, puduit, it shames.

Cf. 118.

recordor, -ārī, -ātum, recall. 116 .

remittō, -ere, -mīsī, -missum, send back, return.

\section{LESSON XI}

audācia, -ae, f., daring, audacity. cōgitō, -āre, -āvī, -ātum, plan, plot. With acc., or dē + abl. coniūrātus, -ī, m., conspirator. cōnsilium, cōnsilī, n., plan, deliberations.

dētrimentum, -ī, n., harm, loss. dīvidō, -ēre, -vīsī, -vīsum, divide, separate.

ēmittō, -ere, -mīsī, -missum, send forth, let go.

exitium, -ī, n., destruction. exsilium, exsilī, n., exile.

famēs, -is, f., hunger.

grātia, -ae, f., gratitude, good will. influence; grātiam habeō, be thankful; grātiās agō, thank, render thanks; grātiam referō, requite.

impendeō, -ēre, -, 一, hang over, threaten.

inopia, -ae, f., want, need. invidia, -ae, f., envy, hatred, unpopularity. miser, misera, miserum, unfortunate, wretched, poor.

molior, -īrī, -ītus sum, plan, plot, contrive.

ostentō, -āre, -āvī, -ātum, show, display.

particeps, participis, participant, sharer. Cf. 113, 114.

perniciēs, -èì, f., destruction.

\section{LESSON XII}

acsī,

velutsī, as if. Cf. 313. tamquamsi,

adhūc (adv.), hitherto, up to this time, still.

alloquor, -loquī, -locūtus sum, address, speak to.

cōnfïrmō, -āre, -āvī, -ātum, strengthen, affirm, assure, assert. exeō, -īre, -iī, -itum, | forth, go discēdō, -ere, -cessī;, out, leave. -cessum,

ègredior, ēgredī, ègressus sum, With ex + abl.

gerō, -ere, gessī, gestum, carry on; mē gerō, act, conduct-self, behave.

improbus, -a, -um, wicked, base. incendō, -ere, -cendī, -cēnsum, set fire to, burn.

inveniō, -īre, -vēnī, -ventum, find, discover.

potius (adv.), rather, preferably.

prūdentia, -ae, f., foresight, wisdom.

sevēritās, -tātis, f., severity. socius, -ī, m., associate, comrade, ally, follower, accomplice. supersum, -esse, -fuī, -futūrus, be left, survive. 
su icipiō, -ere, -cēpī, -ceptum, undertake, incur.

te tis, -is, m., witness.

to : (indecl. adj.), so many.

to lō, -ere, sustulī, sublātum, remove, make way with.

vix (adv.), scarcely, barely, with difficulty.

\section{LESSON XIII}

a jiciō, -ere, -iēcī, -iectum, cast aside, give up.

caedēs, -is, f., slaughter, murder, death.

comparō, -āre, -āvī, -ātum, gather, prepare.

cōnferō, -ferre, -tulī, -lātum, gather together; mē cōnferō, betake - self.

coniūrō, -āre, -āvī, -ātum, conspire. cōnsilium, cōnsilī, n., plan, design. dēsinō, -ere, -sīvī, -situm, cease, stop, leave off.

dēsistō, -ere, -stitī, -, cease, leave off, desist.

frūstrā (adv.), in vain, unsuccessfully.

genus, generis, n., class. gaudeō, -ēre, gāvīsus ) sum, rejoice. laetor, -ārī, -ātus sum, item (adv.), likewise.

mereor, -ērī, -itus sum, deserve. Also active, mereō, -ēre, -uī, -itum.

mūtō, -āre, -āvī, -ātum, change. nisi, unless, except. Cf. 299, 2. nōlī (sing.), $\left\{\begin{array}{l}d o \text { not, don't. Im- } \\ \text { perative of nōlōe (plur.), } \\ \text { followed by the in- } \\ \text { finitive. Cf. 240: }\end{array}\right.$ oppōnō, -ere, -posuī, -positum, oppose. The object must be expressed.

poena, -ae, f., punishment, penalty; poenãs pendō, pay the penálty; poenās persolvō, pay the penalty; poenas dō, pay the penalty.

Quīīiēs, -ium, m., pl., citizens. fellow-citizens.

ut, as (with indic.).

quem ad modum, as.

verbum, -ī, n., word, term.

\section{LESSON XIV}

adsequor, -sequī, -secūtus sum, accomplish, attain.

aes, aeris, n., brass, money; aes aliēnum, debt.

audeō, -ēre, ausus sum, dare.

comprimō, -ere, -pressī, -pressum, crush, overwhelm, suppress.

cōnātus, -ūs, m., attempt.

cōnficiō, -ere, -fēcī, $\left.\begin{array}{c}\text {-fectum, } \\ \text { cōnsequor, -sequī, } \\ \text {-secūtus sum, }\end{array}\right\} \begin{gathered}\text { carry out, ac- } \\ \text { complish. }\end{gathered}$ dēficiō, -ere, -fēcī, -fectum, fail. discō, -ere, didicī, - learn. flōs, flōris, m., flower.

gerō, carry on; geritur, go on, happen.

implōrō, -āre, -āvī, -ātum, implore, beg.

improbus, -ī, m., scoundrel, wicked man.

opprimō, -ere, -pressī, -pressum, check.

ostendō, -ere, ostendī, ostentum, show, explain.

plācō, -āre, -āvī, -ātum, appease, win over, conciliate. 
quiētus, -a, -um, quiet, undisturbed.

rēs, rē̄, f., fact.

rōbur, roboris, n., strength, power. scelerātus, -ī, n., criminal.

studium, -ī, n., zeal, effort.

ulcīscor, ulcīscī, ultus sum, punish, avenge.

\section{LESSON XV}

Learn carefully the list of words in 336 .

abdicō, -āre, -āvī, -ātum, with reflexive, resign; mē abdicō, I resign. Cf. 149.

aperiō, -īre, aperuī, apertum, open.

aspiciō, -ere, aspēxī, aspectum, look at, regard, look upon.

comperiō, -ìre, -perī, -pertum, find out, discover.

comprehendō, -ere, -prehendī, -prehēnsum, arrest.

cōnfiteor, ērī, -fessus sum, confess, acknowledge.

cūstōdia, -ae, f., custody; in cūstōdiam dō, put in prison, imprison.

dēcernō, -ere, -crēvī, -crētum, decree, pass a decree. èdō, -ere, ēdidī, èditum, give forth. indicium, indicī, n., testimony, evidence.

legō, -ere, lēgī, lēctum, read.

litterae, -ārum, f. pl., letter, dispatch. Cf. letter in EnglishLatin Vocabulary.

magistrătus, -ūs, 'm., office, magistracy, magistrate.

mandātum, -ī, n., instruction, order. multō, -āre, -āvī, -ātum, punish; morte multō, punish with death, inflict the death penalty on.

ōrātiō, -ōnis, f., speech; ōrātiōnem habeō, deliver a speech.

prīnceps, prīncipis, m., leading man, prominent man.

prōpōnō, -ere, -posuī, -positum, set forth, tell, declare.

\section{LESSON XVI}

animus, -ì, m., mind, disposition, intention; bonō (amīcō) animō, well disposed; inimīcō animō, ill disposed, hostile.

calamitās, -tātis, f., loss, disaster. cāsus, -ūs, m., chance, misfortune. collocō, -āre, -āvī, -ātum, place, set up, station.

condō, -ere, -didī, -ditum, found. cōnficiō, -ere, -fēcī, -fectum, settle. dēprehendō, -ere, -prehendī, -prehēnsum, discover, catch.

dissēnsiō, -ōnis, f., disturbance, dissension.

ergã (prep. with acc. case), for, toward.

gaudium, gaudī, n., pleasure, joy. lēx, lēgis, f., law, principle.

patefaciō, -ere, -fēcī, -factum, lay open, disclose.

ratiō, -ōnis, f., way, means, manner, plan, scheme.

sapiēns, -entis, wise; as a noun, m., a wise man, a philosopher. sententia, -ae, f., opinion, advice, motion.

suā sponte, of his own accord; meà sponte, of my own accord. supplicātiō, -ōnis, f., thanksgiving. uxor, -ōris, f., wife. 


\section{LESSON XVII}

Learn carefully the lists of words in $148-149 ; 159,165$.

( arcer, carceris, m., prison. ( areō, -ēre, -, 一, lack, be without, go without. Cf. 153. $\left.\begin{array}{l}\text { :ausa, -ae, f., } \\ \text { iès, reī, f., }\end{array}\right\}$ case. :ēnseō, -ēre, cēnsuī, cēnsum, be of the opinion, give one's opinion, decree.

fruor, fruī, frūctus sum, enjoy. Cf. 165.

fungor, fungī, fūnctus sum, perform. Cf. 165.

hūmānitäs, -tātis, f., kindness, human feeling, refinement, culture. insidiae, -ārum, f. pl., plot, stratagem, treachery, ambuscade. lēnis, -e, lenient, mild, kindhearted.

lēnitãs, -tätis, f., leniency, mildness, kind-heartedness.

lïber, lībera, lïberum, free, free from. Cf. 149.

mitis, -e, mild, gentle, compassionate.

nefärius, -a, -um, wicked, infamous.

opus (indecl. noun), need. Cf. 155. prīvō, -āre, -āvī, -ātum, deprive. Cf. 149.

profectō (adv.), surely, certainly, to be sure.

sevērus, -a, -um, severe, harsh, stern.

singulāris, -e, extraordinary, unusual.

spoliō, -āre, -āvī, -ātum, despoil, rob. supplicium, -ī, n., punishment; supplicium dē aliquō sūmō (-ere, sūmsī, sūmptum), inflict punishment on any one.

ūtor, ūtī, ūsus sum, use, employ, show. Cf. 165.

vacuus, -a, -um, free from, unoccupied, destitute of. Cf. 149.

vehemēns, -entis, severe, forcible, harsh.

virtūs, -tūtis, f., manliness, virtue, courage, noble conduct.

\section{LESSON XVIII}

comes, comitis, m. or f., companion.

crūdēlis, -e, cruel.

dignus, -a, -um, worthy; dignus sum quī + subjunctive, deserve. Cf. 145 and 275, 1.

patrēs cōnscrīptī, patrum cōnscrīptōrum, m. pl., senators. sententia, -ae, f., advice, opinion.

\section{LESSON XIX}

Learn carefully the list of words in 283.

ad (prep. with acc. case), to, near, before.

adferō, -ferre, attulī, adlātum (allātum), bring to.

adhūc (adv.), hitherto, up to this time, still.

adsequor, -sequī, -secūtus sum, accomplish, secure.

āvertō, -ere, -vertī, -versum, avert, ward off, turn aside.

cōnstituō, -ere, -stituī, -stitūtum, decide. Cf. 329.

cōnsulātūs, -ūs, m., consulship, the office of consul. 
crēber, crēbra, crēbrum, frequent, numerous.

creō, -āre, -āvī, -ātum, elect, choose. Cf. 68.

cum (conj.), when, whenever. 277-282.

cum . . . tum, not only . . . but also, both . . and. Cf. 280, note.

ērumpō, -ere, -rūpī, -ruptum, burst forth.

ira, -ae, f., anger, wrath.

obstō, -stāre, -stitī, -, oppose, thwart, resist.

rēs pūblica, reī pūblicae, $f$., the public interests, the state, the government.

simulac or simulatque, as soon as. Cf. 283.

vis (vīs), f., force, violence; per vim, by force, by violence, forcibly.

voluntās, -tātis, f., good will, wish, consint.

\section{LESSON $X X$}

Learn carefully the lists of words in 285, 288, 290.

abhorreō, -ēre, -uī, - , shrink from, be at variance with, be inconsistent with.

caput, capitis, n., head, death cēnseō, -ēre, cēnsuī, cēnsum, decree, enjoin.

cōnstituō, -ere, -stituī, -stitūtum, lay down, pass (a law). domicilium, $-\mathbf{i}, \mathrm{n}$., home, residence. dum, while; as long as; until; provided that. Cf. 285-288, 290.

familiāris, -e, friendly, intimate; as a noun, a friend, an intimate friend.

fīnis, -is, m., end; fīnem faciō, make an end, finish.

iūdicō, -āre, -āvī, -ātum, decide.

labor, labōris, m., toil, hardship, effort.

mōs, mōris, m., custom, habit:

ōrdō, ōrdinis, m., rank, grade, class.

pariō, -ere, peperī, partum, procure, acquire, gain.

praeter (prep. with acc. case.), except, beside.

prōpōnō, -ere, -posuī, -positum, set forth, offer.

$\left.\begin{array}{l}\text { rēs, reī, f., } \\ \text { causa, -ae, f., }\end{array}\right\}$ question.

sententia, -ae, f., opinion; sententiam ferō, express an opinion, vote.

subeō, -īre, -iī, -itum, endure, undergo, submit to.

suscipiō, -ere, -cēpī, -ceptum, undertake, incur, make (an enemy).

teneō, -ēre, -uī, tentum, hold, retain.

\section{LESSON XXI}

accipiō, -ere, -cēpī, -ceptum, take, receive, welcome.

adficiō, -ere, -fēcī, -fectum, treat. ascrībō, -ere, -scrīpsī, ascrīptum, enroll.

cohortor, -ārī, -ātus sum, encourage, address.

doctrina, -ae, f., learning.

doctus, -a, -um, learned.

èdūcō, -ere, -dūxī, -ductum, lead out, draw (a sword). 
' rrō, -āre, -āvī, -ātum, wander, go astray, be mistaken, make a mistake.

( xerceō, -ēre, -uī, -itum, train, practice; iūdicium exerceō, conduct a trial, preside over a trial. t rūctus, -ūs, m., fruit, enjoyment. (enus, generis, n., race, kind, class, style.

ingenium, $-\overline{1}, \mathrm{n} .$, talent, genius, inborn quality.

lēgem ferō, pass a law.

litterae, -ārum, f. pl., letter, letters, literature.

novus, -a, -um, new, strange, unusual.

inūsitātus, -a, -um, unusual, extraordinary.

petō, -ere, -īvī, -ìtum, seek, attack. poēta, -ae, m., poet.

praecipiō, -ere, -cẹpī, -ceptum, instruct, teach.

rēs gestae, rērum gestārum, f. pl., achievements, exploits.

sanciō, -īre, sānxi, sānctum, decree, ordain, provide.

\section{LESSON XXII}

Learn carefully the lists of words in 189, 196, 194. celeber, -bris, -bre, crowded, populous; famous.

cīvitās, -tātis, f., state, citizenship. cōnferō, -ferre, -tulī, -lātum

(collātum), bring together; devote; mē ad aliquid cōnferō,

I devote myself to something. contineō, -ēre, -uī, -tentum, hold together, hold in, confine, hold in restraint.

corpus, corporis, n., body. dōnō, -āre, -āvī, -ātum, present, give. Cf. 78, $a$.

exiguus, -a, -um, narrow, small, meager.

foris (adv.), out of doors, abroad. iūdex, iūdicis, m., judge, juror; iūdicēs, gentlemen of the jury. locus, $-\overline{1}, \mathrm{~m}$. (n. in pl.), spot, place, station.

militiae (loc. of militia), in war, abroad, in the field (of war). nōbilis, -e, noble, high (station), of high station.

occurrō, -ere, -cucurrī, -cursum, go to meet, meet.

orbis, -is, m., circle; orbis terrae or orbis terrārum, the world, the earth.

rūs, rūris, n., country (as opposed to the city). Cf. 194.

terrā marīque, on land and sea. versus, -ūs, m., verse. vulnus, vulneris, n., wound.

\section{LESSON XXIII}

Learn the lists of words in 291, 314.

addō, -ere, addidī, additum, add. aliēnus, -a, -um, of another; aliēnus, $-\overline{\mathbf{1}}, \mathrm{m} .$, a foreigner. aptus, -a, -um, suited, fit. Cf. 9293.

contineō, -ēre, -uī, -tentum, hold together, connect.

fortūnātus, -a, -um, fortunate. iniūriā (adv.), unjustly. Cf. 132. iūre (adv.), justly, legally. Cf. 132. pertineō, -ēre, -uī, ${ }^{\wedge}$-tentum, concern, pertain, have to do with; with ad and the accusative. praesertim (adv.), especially. 
quamvis (conj.), however much, although. Cf. 319.

rem agō, conduct a trial, conduct a case.

tabula, -ae, f., record, document. tantum (adv.), only, merely. vērō (adv.), really, truly. Cf. 412. vērum (conj.), but.

\section{LESSON XXIV}

Learn the lists of words in 176 , 177.

ante Chrīstum nātum, before the birth of Christ, B.c. Cf. 184. celerō, -āre, -āvī, -ātum, hurry, hasten.

clārus, -a, -um, famous, renowned. commoveō, -ēre, -mōvī, -mōtum, move; mē commoveō, I make a move (reflexive).

cōnferō, -ferre, -tulī, -lātum (collātum), postpone.

cōnsūmō, -ere, -sūmpsī, -sūmptum, spend.

İdūs, -uum, f. pl., the Ides. Cf. $177,179,180$.

inlūstrō (illūstrō), -āre, -āvī, -ātum, bring to light, disclose.

Kalendae, -ārum, f. pl., the Kalends. Cf. 177, 179, 180.

mēnsis, -is, m., month.

nāscor, nāscī, nātus sum, be born. Nōnae, -ārum, f. pl., the Nones.

Cf. 177.

påcō, -āre, -āvī, -ātum, subjugate.

praeclärus, -a, -um, famous, renowned, distinguished, splendid. prìdiē (adv.), the day before.

$179,2$.

prōcōnsul, -is, m., governor. vesper, vesperī, m., evening.

\section{LESSON XXV}

abeō, -īre, -ī̄, -itum, go away, leave.

aetās, -tātis, f., age.

amplus, -a, -um, large, great; verba amplissima, the strongest terms.

arbitror, -ārī, -ātus sum, consider, think.

causa, -ae, f., cause, case, question, subject.

conveniō, -ìre, -vēnī, -ventum, assemble, come together.

frequēns, frequentis, crowded, in great numbers, numerous.

frētus, -a, -um, relying on, trusting in. With abl. Cf. 137.

gerō, -ere, gessī, gestum, accomplish, geritur, take place, happen.

impetrō, -āre, -āvī, -ātum, gain a point, gain one's request. ineō, -īre, -īi, -itum, enter, go in; cōnsilium ineō, adopt a plan; iniēns aetās, early manhood.

iūcundus, -a, -um, pleasing, pleasant; iūcundissimum est, it is a very great pleasure.

māiōrēs, -um, m. pl., ancestors. Cf. 3.

mandō, -āre, -āvī, -ātum, intrust, instruct, order. Cf. 262. occupō, -āre, -āvī, -ātum, seize, occupy, keep busy.

populäris, -e, of the people, popular, democratic.

praemium, -ī, n., reward, prize, tribute.

ratiō, ratiōnis, f., plan, method, means, manner, scheme. 
I gius, -a, -um, of a king, with a (the) king, royal. Cf. 98. aiversus, -a, -um, whole, all, entire. v rtūs, virtūtis, f., manliness, courage, virtue, ability.

\section{LESSON XXVI}

a bhinc (adv.), ago. Cf. 173. adorior, -orīīi, -ortus sum, attack. aggredior (adgredior), -gredī, -gres-

sus sum, approach, attack. agō, -ere, ēgī, āctum; aliquid agitur, something is at stake; agitur dē aliquā rē, it is a question of something.

attribuō, -ere, tribuī, -tribūtum, assign, intrust.

bona, -ōrum, n. pl., goods, property. Cf. 3.

commūnis, -e, common, of all.

ferē (adv.), almost, nearly, 411.

paene (adv.), almost, nearly. 411.

gravis, -e, heavy, oppressive.

imperium, -ī, a., power, command, supremacy.

interest, -esse, -fuit, -, it is to the interest, it concerns, it is of importance. Cf. 124-125.

minor, -ārī, -ātus sum, threaten. modus, kind, character, means, manner; èius modi, of such a character, such.

nōndum (adv.), not yet.

quantopere, quam vehementer, $\}$ how greatly. rēgnō, -āre, -āvī, -ātum, reign, be king.

studium, -ī, n., zeal, enthusiasm, eagerness, study. triumphō, -āre, -āvī, -ātum, celebrate a triumph; . . over, dē . . . vectigal, -ālis, n., revenue.

vehementer (adv.), very, exceedingly, very much.

\section{LESSON XXVII}

adsum, -esse, -fuī, -futūrus, $b \epsilon$ present, be at hand, aid. adventus, -ūs, m., arrival, approach. audāx, audācis, bold, daring .

colō, -ere, coluī, cultum, till, cultivate, cherish.

cūnctus, -a, -um, all, whole. Cf. 189.

cūra, -ae, f., care, concern; cūrae est alicui, it concerns some one. Cf. 90-91.

forte (adv.), perhaps, by chance. ignnōrō, -āre, -āvī,

-ātum, not know, be nesciō, -īre, -īvī, ignorant. -ìtum,

inimicus, -a, -um, hostile; inimīcus, $-\bar{i}, \mathrm{~m}$., (personal) enemy. Cf. hostis.

ita . . ut . . . nōn, so . . that .. . not, without. Cf. 259, a. mercātor, -ōris, m., merchant, trader.

minuō, -ere, minuī, minūtum, lessen, diminish, make less. minuitur, lessen, grow less.

nauta, -ae, m., sailor. nāvigō, -āre, -āvī, -ātum, sail. solvō, -ere, solvī, solūtum, loose; (nāvem) solvō, set sail, sail. pendō, -ere, pependī, pēnsum, weigh out, pay.

plēnus, -a, -um, full. Cf. 113114. 
refertus, -a, -um, full, crowded. Cf.' 115.

quaestus, -ūs, m., gain, profit, business.

turpis, -e, base, disgraceful.

\section{LESSON XXVIII}

appetēns, -entis, desirous, eager for, covetous, greedy. Cf. 113114.

argentum, -ī, n., silver.

aurum, -i, n., gold.

avidus, -a, -um, eager, desirous, greedy. Cf. 113-114.

brevis, -e, short; brevī tempore, soon.

colligō, -ere, -lēgī, -lēctum, collect, gather.

effugiō, -ere, -fūgī, -fugitum, flee, escape, slip from.

èlābor, -lābī, -lapsus sum, slip out, escape, slip from.

exemplum, -ī, n., precedent, example.

iuvō, -āre, iūvī, (iūtum), help, aid, assist. Cf. 81.

manus, -ūs, f., hand, band.

mox (adv.), soon.

nimis (adv.), too.

nimium (adv. and indecl. noun), too much. Cf. 105.

obsideõ, -ēre, -sēdī, -sessum, besiege.

ōdī, (ōdisse), ōsūrus, hate.

oppūgnō, -āre, -āvī, -ātum, attack, besiege.

patrius, -a, -um, ancestral, of a father, paternal; patria, -ae, f., fatherland.

praeda, -ae, f., booty.

subsidium, $-\overline{\mathrm{i}}, \mathrm{n}$., aid, rë̈nforcement. tantus, -a, -um, so, so great, so large, so important, such, such important.

tempus, temporis, n., time; difficile tempus, crisis.

trādō, -ere, -didīi, -ditum, hand over, give over, surrender.

vetus, veteris, old, ancient, of old. vīs, (vīs), f., force, power, amount, quantity.

\section{LESSON XXIX}

absum, -esse, āfuī, āfutūrus, be away, be absent, be distant.

adferō, -ferre, attulī, adlātum (allātum), bring to.

adulēscentia, -ae, f., youth, manhood.

auctōritās, -tātis, f., prestige, influence, authority.

classis, -is, f., fleet.

commemorō, -āre, -āvī, -ātum, recall, speak of, mention.

commūtātiō, -ōnis, f., change.

dīgnitās, -tātis, f., worth, dignity, prestige.

extrēmus, -a, -um, end of, farthest, last. Cf. 108.

fēlīcitās, -tātis, f., luck, good fortune, success.

in aliquō est, some one possesses (used of traits of character). insignis, -e, marked, conspicuous, distinguished, remarkable.

nūper (adv.), lately, recently, not long ago.

pār, paris, equal, like, alike, on a par with, a match for. Cf. 92.

praedō, -ōnis, m., robber, pirate, plunderer. 
I ropter (prep. with acc. case),

, b (prep. with acc. case),

؛ cientia, -ae, f., knowledge, acquaintance with.

؛ ingulāris, -e, special, extraordinary, unusual, remarkable. :ummus, -a, -um, highest, greatest, (in the) highest (degree). Cf. 108.

rictor, -ōris, m., victor, conqueror; as an adj., victorious.

\section{LESSON XXX}

aspiciō, -ere, aspēxī, aspectum, look upon, regard, look at. avāritia, -ae, f., greed.

commendō, -āre, -āvī, -ātum, intrust.

cōnferō, -ferre, -tulī, -lātum (col-

lātum), bring together, compare. dēvocō, -āre,' -āvī, -ātum, call aside.

dīripiō, -ere, -uī, -reptum, seize, plunder, pillage.

ēgregius, -a, -um, extraordinary, exceptional.

fidēs, -eī, f., trustworthiness, honesty.

fortūnae, -ārum, f. pl., fortunes. rēs, rērum, f. pl., fortunes, property.

innocentia, -ae, f., blamelessness, integrity, blameless conduct.

invitus, -a, -um, unwilling; frequently to be rendered as an adv., unwillingly, against one's will.

më gerō, act, behave, conduct myself, act. memor, memoris, mindful, remembering. Cf. 113-114.

neglegō, -ere, -lēxī, -lēctum, neglect, disregard, pass over.

serviō, -īre, -īvī, -ìtum, serve, be a slave to.

temperantia, -ae, f., self-control, self-restraint, moderation, temperance.

\section{LESSON XXXI}

administrō, -āre, -āvī, -ātum, manage, carry on, conduct.

āmittō, -ere, -mīsī, -missum, lose. commemorō, -āre, -āvī, -ātum, recall, recount.

contemnō, -ere, -tempsī, -temptum, despise, disregard, hold in contempt.

diversus, -a, -um, separate, distant, various, different.

exter(us), -a, -um, outer, outside, foreign.

maritimus, -a, -um, of the sea, sea-, naval.

unde (adv.), whence, from which. valet, valēre, val-

uit, valitūrus, be of imporpotest, posse, tance. Cf. 66 . potuit, -

\section{LESSON XXXII}

amāns, amantis (partic. of amō), loving; amāns patriae, or amāns reì pūblicae, patriotic.

concēdō, -ere, -cessī, -cessum, allow, grant, assign, yield. dēferō, -ferre, -tulī, -lātum, carry away, report, confer, devote. tribuō, -ere, tribuī, tribūtum, grant, assign, confer, bestow. 
doceō, -ēre, -uī, doctum, teach, show, inform.

dēmōnstrō, -āre, -āvī, -ātum, point out, show, state, mention, indicate.

ostendō, -ere, ostendī, ostentum, show, declare, indicate.

ōra, -ae, f., shore, coast; ōra maritima, sea coast.

praeditus, -a, -um, endowed, furnished, supplied, possessing. With abl.

\section{LESSON XXXIII}

fäma, -ae, f., reputation, fame, glory.

fruor, fruī, frūctus sum, enjoy. Cf. 165.

glōria, -ae, f., fame, glory, renown.

quantō ....tantō, $\left\{\begin{array}{l}\text { with compara- } \\ \text { tives, the } \\ \ldots \text { hōc, }\end{array}\right\}$ the ... mägnopere (adv.), very much, greatly.

particeps, -cipis, participant, sharer, associate.

vehementer (adv.), severely, strongly, very, very much, exceedingly, greatly.

\section{LESSON XXXIV}

avāritia, -ae, f., greed, avarice. cupiditās, -tātis, f., desire, eagerness, greed.

libenter (adv.), gladly, freely. laetē (adv.), gladly, joyfully. militāris, -e, of the soldiers, military; rēs mīlitāris (sing.), military affairs, the art of war. minae, -ārum, f. pl., threats; vis et minae, threats of force. plūs (noun), more.

magis (adv.), more.

quisquis, quicquid, whoever, whosoever.

quīcumque, quiccumque, whichsoever, whosoever, whatsoever.

\section{LESSON XXXV}

abiciō, -ere, -iēcī, -iectum, throw away, throw down, lay down. aegrē (adv.), with difficulty, scarcely, hardly.

vix (adv.), with difficulty, hardly, scarcely.

colloquor, -loquī, -locūtus sum, speak with, confer, talk together. conclāmō, -āre, -āvī, -ātum, cry out, shout.

condiciō, -ōnis, f., terms, conditions.

dìmittō, -ere, -mīsī, -missum, let go away, let slip, neglect, abandon.

efferō, -ferre, extulī, èlātum, carry away, elate.

èlābor, èlābí, èlapsus sum, slip out, escape.

fidēs, -eī, f., trustworthiness, word (of honor).

impetrō, -āre, -āvī, -ātum, obtain (a request), be successful (in obtaining something); impetrō ab aliquō, prevail upon any one. .

interpōnō, -ere, -posuī, -positum, interpose, introduce, pledge.

occāsiō, -ōnis, f., opportunity, chance.

ōrdō, ōrdinis, m., rank. 
pı rmoveō, -ēre, -mōvī, -mōtum, move, affect, alarm.

pirpetuus, -a, -um, permanent, everlasting; in perpetuum, forever.

pi rturbō, -āre, -āvī, -ātum, disturb, throw into confusion.

procul (adv.), at a distance, from a distance, far away.

\section{LESSON XXXVI}

a jsum, -esse, āfuī, āfutūrus, be absent; absēns, absentis (partic. of absum), absent; mē absente, in my absence.

a:cessō, -ere, -īvī, -ītum, summon. māgnum iter, māgnī itineris, n., a forced march.

impellō, -ere, -pulī, -pulsum, drive on, impel, influence.

praestat, -āre, -stitit, -, it is better.

peragō, -ere, -ēgī, -āctum, conduct through, carry through, finish, accomplish.

recuperō, -āre, -āvī, -ātum, get back, recover, regain.

umor, -ōris, m., rumor, story, report, account.

subiciō, -ere, -iēcī, -iectum, place under, subject.

\section{LESSON XXXVII}

adeō (adv.), so, so much. amplius (adv., comp. of amplē), farther, longer, more, farther away. Cf. 159.

beneficium, -ī, n., a kindness, a favor, a service.

certus, -a, -um, fixed, appointed, certain. cōnfiteor, -ērī, -fessus sum, confess, acknowledge.

dēbeō, -ēre, -uī, -itum, owe, ought; in passive, be due.

dēdūcō, -ere, -dūxī, -ductum, lead away, conduct off.

èdūcō, -ere, -dūxī, -ductum, lead out.

imperītus, -a, -um, unacquainted with; imperītus rērum, ignorant. iūs, iūris, n., right, rights, control. multitūdō, -dinis, f., the multitude, the people.

$\left.\begin{array}{l}\text { opera, -ae, f., } \\ \text { auxilium, -i, n., }\end{array}\right\}$ help, aid.

praesertim (adv.), especially.

recūsō, -āre, -āvī, -ātum, refuse. Cf. 269-270. With dat. of the person.

referō, -ferre, rettulī, relātum, bring back, return; grātiam referō, return thanks, make a grateful return, requite.

remittō, -ere, -mīsī, -missum, send back, return.

resistō, -ere, -stitī, -, resist, hold out against. Cf. 79-80. servitūs, -tūtis, f., slavery, servitude.

stipendium, -ī, n., tax, tribute.

superō, -āre, -āvī, -ātum, overcome, subdue.

\section{LESSON XXXVIII}

abiciō, -ere, -iēcī, -iectum, hurl (away), cast aside.

aciēs, -ēī, f., line (of battle).

admittō, -ere, -mīsī, -missum, let go; equō admissō, with horse at full speed.

aequus, -a, -um, equal, favorable. 
iniqquus, -a, -um, unequal, unfavorable.

appetō, -ere, -īvī, -ìtum, seek for, aim at, thrust at.

arduus, $-\mathrm{a},-\mathrm{um}$, steep.

ascēnsus, -ūs, m., ascent.

cernō, -ere, crēvī, crētum, dis-

tinguish, see, descry.

cōnspiciō, -ere, -spēxī, -spectum, catch sight of, espy, see.

concīdō, -ere, -cīdī, -cīsum, kill, slay, cut down.

convertō, -ere, -vertī, -versum, turn about; mē convertō, face about.

expeditus, -a, -um, light armed, unencumbered.

levis, -e, light.

prōcurrō, -ere, -cucurrī or -currī, -cursum, run forward, charge. praecurrō, -ere, -cucurrī or -currī, -cursum, run on before, hasten in advance.

sublevō, -āre, -āvī, -ātum, assist, help.

tergum, -ī, n., back; terga vertō, turn and flee; à tergō, in the rear.

tollō, -ere, sustulī, sublātum, raise, remove, destroy, make way with.

umerus, -ī, m., shoulder.

ūnā (adv.), along, together; ūnā cum, along with. uterque, utraque, utrumque, either, both.

vallēs, -is, f., valley.

vìtō, -āre, -āvī, -ātum, avoid, escape.

vertō, -ere, vertī, versum, turn, change.

\section{LESSON XXXIX}

adeō, -īre, -īi, -itum, go to, $a p$ proach.

aestimō, -āre, -āvī, -ātum, value, estimate, consider. Cf. 122.

cōnfugiō, -ere, -fūgī, -fugitum, flee (for refuge).

extrēma fortūna, extremity (of danger).

hic, hūius, this man $=$ my client.

luxūria, -ae, f., luxury, extravagance.

negōtium, -ī, n., undertaking, task, business.

possideō, -ēre, -sēdī, -sessum, occupy, possess, be in possession of.

restō, stāre, -stitī, - remain, be left; restat ut . ., it remains for . . . Cf. 264 .

sēdēs, -is, f., abode, seat, dwelling place.

domicilium, -ī, n., dwelling place, abode, residence.

voluptās, -tātis, f., pleasure.

\section{LESSON XL}

agitō, -āre, -āvī, -ātum, stir up, arouse, agitate, incite.

ago or gerō; in the passive, go on, happen.

collēga, -ae, m., colleague.

cupiō, -ere, -īvī, -ītum, desire.

dēbilitātus, -a, -um, weakene. weak.

dēfēnsor, -ōris, m., defender, protector.

dēmoveō, -ēre, -mōvī, -mōtum, move away, remove.

inermis, -e, unarmed, without arms. malum, -ī, n., evil, misfortune. 
nu lior, -īrī, -ìtus sum, plan, con-|prīoō, -āre, -āvī, -ātum, deprive. rive, attempt, undertake, set about. . Cf. 149.

ni men, nōminis, n., name; meō spoliō, -āre, -āvī, -ātum, deprive, nōmine, in my name, on my account, in my honor.

ol iciō, -ere, -iēcī, -iectum, throw up against, expose.

pr aesidium, -ī, n., protection, guard, guardianship. rob, despoil. Cf. 149.

triennium, -ī, n., three years, a period of three years. videō, -ēre, vīdī, vīsum, see, observe. 


\section{REFERENCES TO GRAMMARS}

\section{PART III}

Note. All the constructions employed in the lessons are explained fully in the Elements of Syntax which comprises the first portion of this book. The following references are for use in connection with the grammars of Gildersleeve and Lodge (G.), Allen and Greenough (A.), Bennett (B.), and Harkness (H.), where such reference is desired. The references in parentheses are to the older edition of Allen and Greenough.

\section{Lesson I. Pronouns; Agreement}

Pronouns, Personal: G. 304; A. 295 (194); B. 242; H. 500, 4.

Demonstrative: G. 305-308, 310-311; A. 296-298 (195); B. 246-249; H. 505-509.

Reflexive: G. $309,520-521$; A. 300-301 (196, $a, 1,2)$; B. 244245 ; H. 502-504.

Relative: G. $610-613,618$; A. 304-308 (198-201); B. 250-251; H. $510,1,6$.

Indefinite: G. 313-319; A. 309-315 (202-203); B. 252-253; H. $512-516$.

Possessive: G. 312 ; A. 302 (197); B. 243; H. 501.

Adjective Agreement: G. 286, 1; A. 286, $a, 287,1-4$ (186-189); B. 235, A, 1, 2, B, 1, 2, $a, b$; H. 395, 1-3.

Relative, Agreement of: G. 614, R. 1, 2, 5; A. 305, a, 306, 307, $d, 308, a, f(198,199,200, e, 201, a, e)$; B. $250,1-3,251,2-5$; H. 396, 1, 398, 1, 2.

Verb, Agreement of: G. 285, 1-3, 287; A. 316, 317, $a-d$ (204, $205, a)$; B. 255, 1-5; H. 392, 1, 2, 4, 5. 


\section{Lesson II. Tenses of the Indicative}

Present: G. 230 ; A. $466(276, a)$; B. 259,4 ; H. 533, 1.

Imperfect: G. 231, 233, 234; A. 470, N. 471, $a-c(277, a-c)$; B. ' $; 0,1-4 ;$ H. 530, 534, 1-3, 535, 1.

Future and Future Perfect: G. 242, R. 1, 244, 2; A. 472, b, 478, $(278, b, 281$, R. $)$; B. $261,2,264, a$; H. 540, 2.

Perfect: G. 235, 236, R., 239; A. $473-476(279, e) ;$ B. $262 ;$ H. .j $37,538,4$.

Pluperfect: G. 241 ; A. 477 (280); B. 263 ; H. 539.

\section{Lesson III. The Accusative Case}

Direct Object: G. 330 , R. ; A. $388, a(237, b)$; B. $175,2, b$; H. 105, 1.

With Compound Verbs: G. 331, R. 1, 2; A. 388, b, 395 (237, d, $239,2, b)$; B. 175, 2, a, 179, 1-3; H. 406, 413.

Cognate Accusative: G. $333,1,2$; A. $390, c(238, a-b)$; B. 176, 2,$4 ;$ H. 409, 1.

Extent: G. $334-336$, R. 1; A. $425, b, 423,2(257,256,2)$; B. 181 ; H. 417, $1,3$.

Limit of Motion; G. 416, 1, 418, 1, a, 337; A. 426, 2, 427, 2 (258, $2, b)$; B. $182,1-2$; H. $418,3,419,1$, N.

Double Accusative: G. 339, R. 1-3, 340, R. 1; A. 393, a, 396. $a-c(239,1,2, c-d)$; B. $177,1-3,178,1, a-e, 2$; H. 410, 1, 2, 411, $1-4$.

Exclamations: G. 343,1 ; A. $397, d(240, d)$; B. 183 ; H. $421,1$.

Lesson IV. Questions: Direct and Indirect; Sequence of Tenses

Direct Questions: G. 454, R. 1, 455, 456; A. 331, 332, $a, b$ (210$211)$; B. $162,1,2, a-d$; H. 378, 1-2.

Answers: G. 471; A. 336 (212); B. 162, 5, $a-b$; H. 379, 1.

Moods in Direct Questions: G. 463, 259, 265; A. 157, a, 444, a $(112, a, 268)$; B. 277,271 ; H. 557, 559, 4 .

Indirect Questions: G. 467 ; A. 573, $574(334, a, f)$; B. 300, 1, 3; H. 649, II.

Double Questions: G. 458, 459, 460, $a, b$; A. 334, 335, N. $a, d$ (211); B. $162,4,300,4, a$; H. 380, 1, 650, 1, 2.

Sequence of Tenses: G. 509, 510, 514, 515; A. 482, 1, 2, 483, $484, a-c, 485, a-b, 575, a(283-287)$; B. 258, 267, $1-3,268,1$, $269,1-3$; H. $198,543,544,545$, I, II. 
Lesson V. Purpose Clauses and Result Clauses

Purpose Clauses: G. 545, 1-3, 630; A. 530, 531, 1, 2, a (317-318); B. $282,1, a, d, 2$; H. 568, 6,7 .

Substantive Clauses of Purpose: G. 546, 1, 2, 532; A. 563, $a-b$ $(331, a-e)$; B. $294,295,1, a, 2,4,5,296,1$; H. 564, I-III.

Result Clauses: G. 552, 1, 2, R. 1; A. 537, 1, 2, $538(319,1-3)$; B. $284,1,2$; H. $570,2$.

Substantive Clauses of Result: G. 553, 1-4; A. 567-569, 1-3, $571, b(332, a-c)$; B. 297, 1-3; H. 571, 1-4, 566.

\section{Lesson Vi. The Dative Case}

Indirect Object: G. 345 ; A. $361,362,364,365(224,225, a, d, e)$; B. $187, \mathrm{I}$; H. 424 .

With Special Verbs: G. 346, R. 1 ; A. $367, a, 372(227, a, c, f)$; B. $187, \mathrm{II} ;$ H. 426, 1-3.

With Compound Verbs: G. 347 ; A. $370, a, b, 371(228,230)$; B. 187 , III, 1,2 ; H. $429,1$.

Possessor: G. 349 , R. $2-4$; A. $373, b(231, a)$; B. 190 ; H. 430. Reference: G. 352 ; A. 376 (235) ; B. 188, 1; H. 425, 1, 2, 4.

Agent: G. 355 , R., A. $374, a$, N. 1 (232); B. 189, 1, $a$; H. 431, 1. Purpose: G. 356; A. 382, $1(233, a)$; B. 191, 1, 2; H. 433, 425, 3. With Adjectives: G. 359 ; A. $384(234, a-e)$; B. 192, 1, 2; H. 434, 2.

Lesson Vit. Verbs of Fearing; Verbs of Preventing, etc.; Verbs of Doubting; Characteristic Clauses

Verbs of Fearing: G. 550, 1, 2; A. $564(331 f)$; B. 296, 2, $a$; H. $567,1-4$.

Verbs of Preventing, etc.: G. 548, 549, 554; A. 558, $b$ (331, e, 2, $332, g)$; B. $295,3, a$; H. $568,8,595,2,3$.

Verbs of Doubting: G. 555, 2 ; A. 558, $a$ (332, $g$, R. N.); B. 298; H. 595, 1.

Characteristic Clauses: G. $624,631,1,2$; A. $535, a, b, f(320$, $a, b, f)$; B. 283, 1, 2, 282, 3; H. 591, 1, 4, 5, 7.

Lesson Vili. Gerund; Gerundive; Passive Periphrastic ConJUGATION; SUPINE

Gerund: G. $424-426$; A. 501,502 , N. $(295$, R.); B. $338,1-5$; H. 624, 210, 2.

Gerundive؛ G. 427 ; A. $503, a(294,296$, N.); B. $339,1-3$; H. 623. 
Jses of Gerund and Gerundive: G. 428, R. 1, 2, 429, N. 1, 2, 4304 ; ; A. 504, $b, c, 505, a, 506,507,500,4$ (297, 298, $a, c, 299-301)$; B. 338 entire, $339,5,337,8, b, 2$; H. $622,625,626,3,627-630$.

Passive Periphrastic: G. 251, 1, 2, 355; A. 194, $b, 372,374, a$, ‥ $1,500,2(129,230,232$, N. $294, b)$; B. $115,337,8, a), b), 1,189$, 1. $a ;$ H. $237,302,6,7,431,1,621,1,2$.

Supines: G. $434-436$; A. 509-510 (302-303); B. $340,1, a, 2, b$; I $[633,635$.

\section{Lesson IX. The Genitive with Nouns and Adjectives}

Possession: G. 362 , R. 1,2 ; A. 343 , N. $1, a \cdot(214,2, a-b)$; B. 1 ( 8,199 ; H. 440, 1, N. 2 .

Description: G. 365 , R. 2 ; A. 345 , N. $a, b,(215$, N. $a)$; B. 203 , 1,2 ; H. 440, 3.

Partitive: G. 367-369; R. 1, 370, 372, R. 2; A. 346, $a, 1-4, c$, $d, e(216, a, 1-4, a, d, e)$; B. 201, 1, $a, b, 2, a, b, 3$; H. 440, 5, N. $441,442,2,4,5,443,444,1$.

Objective Genitive with Nouns: G. $363,1,2$; A. $348, c(218, c)$; 33. 200,1 ; H. 440,2 , N. 1 .

With Adjectives: G. 374,375 ; A. $349, a-c(218, a-b)$; B. 204, 1 ; H. 450, 451, 1-3, 453, 1.

Predicate Genitive: G. 366 , R. 2; A. $343, b(214,1, c-d)$; B. $198,3,203,5$; H. 447, 439, 3, 4 .

With causã: G. 373, R. 1, 2; A. $359, b(223, e)$; B. 198, 1; H. 475, 2.

\section{Lesson X. Genitive with Verbs}

Verbs of Memory, etc.: G. 376, R. 1, 2; A. 350, $a, b, d, 351$, N. $(219, a, b, c$, N.) ; B. 206, 1, 2, $a, 207, a, b ;$ H. $454,1,2,455$.

Verbs of Émotion: G. 377 ; R. 3 ; A. $354, a-c(221, a-d)$; B. 209 , $1, a, 2$; H. 457, $2,3$.

Verbs of Accusing, etc.: G. 378, R. 3 ; A. $352,353,1(220, a-d)$; B. $208,1,2, a, b$; H. 456, 1,3 .

Interest and rēfert: G. 381 , N. $1,382,1,2$; A. $355, a(222, a)$; B. 210,211 ; H. $449,1,3$.

Verbs of Rating, etc.: G. $379,380,1$, R. 2 ; A. $417, c(252, a, d)$; B. $203,3,4$; H. $448,1,2,4,5$.

\section{Lesson XI. Conditions}

General Statement: G. 589, 594; A. 512, 514, A-C $(304,305, a-c)$; B. $301 ;$ H. $572,573$.

Logical Conditions: G. 595; A. 515, $a, 516,1, a, c, d(306, a, 307$, $1, a, c, d)$; B. $302,1,4 ;$ H. 574, 2. 
Ideal Conditions: G. 596, 1; A. 516, 2, $b, c(307,2, b, c)$; B. 303; H. 576,1 .

Unreal Conditions: G. 597, R. 3; A. 517, $c, d(308, c, d)$; B. $304,1-3, a, b$; H. 579, 1, 583.

Protasis Implied: G. 600,1 ; A. $521, a, b(310, a, b)$; B. 305,1 ; H. $575,9$.

Lesson XII. Wishes; Potential Subjunctive; Conditional Clauses of Comparison

Wishes: G. 260,261 , R.; A. $441,442, b(267, b, c)$; B. $279,1,2$; H. $558,1,2,4$.

Potential Subjunctive: G. 257, 258, 600, 2; A. 446, 447, 1, 2, 3, N. $(311, a)$; B. $280,1, a, 2-4$; H. 552, 553, 1, 2, 554-556.

Conditional Clauses of Comparison: G. 602; A. 524 (312); B. 307, 1,2 ; H. 584, $1,2$.

Lesson XIII. Commands; Entreaties; Prohibitions

Commands: G. 267, R., 268, 1-2; A. 448, 449, $a$ (269); B. 281, 1 ; H. 522, 560, 2.

Entreaties: G. 263, 1, 3; A. 439 (266); B. 274, 275, 1; H. 559, 1-2.

Prohibitions: G. 270 , R. 2 ; A. $450(269, a, 2)$; B. $276, a, c ; \mathrm{H}$. $561,1,2$.

\section{Lesson XIV. The Infinitive}

Infinitive as Subject: G. $422,424,535$; A. 452, 1-3, 454 (270, $1-3, a-b)$; B. $327,1,2,330$; H. $615,616,1,2$.

Infinitive as Object and Complementary Infinitive: G. 423, 1, 2, 532,533 ; A. 456, 458, 563, $a-d(271, b, c, 331, a-d)$; B. $328,1,2$, 331 , II-V; H. 607, 1, 2, 614, 565, 2, 3, 5.

Lesson XV. The Infinitive (Concluded): Indirect Discourse

Infinitive in Indirect Discourse: G. 527, R. 4, 5; A. 459, 579, $580, b, c, 581(272,336,1,2, a)$; B. $331,314,1,2$; H. $613,1-3$, $642,1$.

Tenses of the Infinitive: G. 529-531, N. 4; A. 486, $a$, 584, $a$ (288, $a, 336$, A) ; B. $270,1, a-c, 2$; H. $617,618,2,619,1$.

Impersonal Construction: G. 528, 1, 2; A. 582, $a(336,1, a, 2)$; B. $332, a)-d)$, N; H. $611,1,2$, N. $1,2$.

Indirect Discourse: G. $648,650,653-655$, R. 1 ; A. 580, 588, a (336); B. 313, 314, 1, 3, 318; H. 641, 643, 3, 644, 2. 


\section{Lesson XVi. The Ablative Case}

Means or Instrument: G. 401 ; A. $409(248, c)$; B. 218 , H. 476. Agent: G. 401 ; A. 405 (246); B. 216; H. 468.

Manner: G. 399 , N. 1 ; A. $412, a, b$ (248); B. 220,1 ; H. 473 , 3, N. Accompaniment: G. 392 ; A. $413(248, a-b)$; B. 222 ; H. 473, I.

Cause: G. 408 ; A. 404 (245); B. 219 ; H. 475.

Description (Quality): G. 400 ; A. 415,345 , N. $a, b$ (251, 215, N.); I3. $224,1,3$; H. 473,2 , N. 1,2 .

Specification (Respect): G. 397 ; A. 418 (253); B. 226 ; H. 480.

\section{Lesson XViI. Ablative Case (Continued)}

Time: G. 393 ; A. 423,1 (256); B. 230-231; H. 486, 487.

Place Where: G. 385 ; A. 426,3 (254); B. 228 ; H. 483.

Place Whence: G. 390,1 ; A. 426, $1(258,1)$; B. 229 ; H. 491, I, 2. Separation: G. $390,2,3,405$; A. 400-402, $a, 356$, N. $(243, a, b$, $(l, f)$; B. 214, 1, a)-d), 2 ; H. 462, 1, 463, 465, 1.

Origin and Material: G. 395-396; A. 403, 1, 2, $a(244, a-d)$; B. 215 ; H. 467.

Comparison: G. 398 ; A. $406,407, a-c(247, a-c)$; B. $217,1-3$; H. $471,1,3,4$.

Degree of Difference: G. 403; A. 414 (250); B. 223; H. 479.

Price: G. 404 ; A. 416 (252); B. 225 ; H. 478, 1.

Ūtor, etc.: G. 407, N. $2(d) ;$ A. $410, a(249, a) ;$ B. 218,$1 ;$ H. 477 , I.

Opus and $\bar{U}_{\text {sus: }}$ G. 406, s. 2 ; A. $411, a(243, e) ;$ B. 218,$2 ;$ H. 477 , III, N.

Lesson XVIII. Conditions in Indirect Discourse; Dependent UNREAL Conditions

Conditions in Indirect Discourse: G. 650, R., 653, 654, 597, R. 4; A. $589,1,2, a, b, 1-4,485, h(337,287, f)$; B. $314,1,319, \mathrm{~A}, \mathrm{~B}, a$, 320, A, B, 321 entire; H. 646, 1, 647, 2, 3 .

Dependent Unreal Conditions: G. 597, r. 5; A. 517, $d$, examples 3-4 (308, $d$, examples 3-4); B. 322 entire; H. 648 entire.

Lesson XiX. Temporal Clauses: Cum-Temporal; Postquam, ETC.

Clauses with cum:

a. Indicative: G. 580,583 ; A. 545,547 (325); B. 288,1, A, 289 ; H. $600, \mathrm{I}, 601$.

b. Subjunctive: G. 585 ; A. 546 , N. 1 (325); B. 288,1, B; H. 600 , II. 
c. Exceptions to $b$ : G. 581, 584; A. 548, 546, $a, 545, a(325, a-c)$; B. 288, B, $a, 2,3$; H. 600 , I, 1, 601, 2, 4 .

Postquam, etc.: G. $561,563,2$; A. 543 (324); B. $287,1,3$; H. $602,1$.

Lesson XX. Temporal Clauses (Continued): Dum-Cuauses, Priusquam, etc.: Proviso

Dum, while - Incomplete Coextension: G. 570; A. $556(328, a)$; B. 293, I; H. 604, 603, I.

Dum, while - Complete Coextension: G. 569 ; A. 555 examples (328); B. 293, II; H. 603, I.

Dum, until: G. 571, 572; A. 553, 554 (328); B. 293, III, 1, 2; H. 603, II, 1, 2.

Proviso: G. 573; A. 528 (314); B. 310,1 , II; H. 587.

Priusquam, etc.: G. 574, 577; A. 551, $a, b(327, a)$; B. 291, 292, $1, a)-c) ;$ H. 605, I.

\section{Lesson XXI. Participles; Ablative Absolute}

Tenses of Participles: G. 282, 283; A. 489-493 $(290, a-d)$; B. 336, 1-5; H. 640, 1.

Participles as Nouns or Adjectives: G. 437, 438; A. 488, 494, a (291, $a-b, 293)$; B. 337, 1 ; H. 636, 640, 1, 494, 495.

Ablative Absolute: G. 409, 410, R. 1, 3; A. 419, a, 493, 1, 2 (255, $a-c)$; B. 227, 1, 2, 4; H. 489, 1, 3, 640, 4 .

Participles for Clauses: G. 664-668; A. 490, 1, 2, 496, ‥ 1, 2, 420, 1-5, $497(292, a, 255, d)$; B. 337, 2, a-f; H. 637, 638, 1, 2, 639.

\section{Lesson XXII. Expressions of Place}

1. Place Where:

a. General Rule: G. 385 ; A. $426,3(258, c, 1)$; B. 228 ; H. 483.

b. Special Uses: G. 385,3 , N. 1,386, R. 2,411 , R. $1-4$; A. 427 , $3,428, b, d(258, c, 2, d-f)$; B. $228,1, a)-c)$; H. 483, 2, 484, 1, 2, N. $1,2,485,2$.

2. Place Whence:

a. General Rule: G. 390, 1; A. 426, $1(258,1)$; B. 229; H. 491, I, 2.

b. Special Uses: G. 390, 2, line 3, 391, r. 1, line 5; A. 427, 1, $428, a-d(258, a$, N. 1$)$; B. $229,1, a), b), 2$; H. 491, II $, 2,462,3,4$.

3. Place Whither:

a. General Rule: G. 345 , R. 2, 416, 1, 418, 1; A. 426, 2 (258, $2)$; B. 182,2 ; H. 418 .

b. Special Uses: G. 337 , R. 2, 4; A. 427, 2, 428, $c, k(258,2, b$, N. $1-3)$; B. $182,1, a), b)$; H. $418,4,419,1$, N. 2. 


\section{Lesson XXIII. Causal and Concessive Clauses}

Causal Clauses. G. 586, 633, 541, 542, 540; A. 540, $a-d(321,1-2)$; I. 286, 1-2, 283, 3, a); H. 588, 598, 592 .

Concessive Clauses: G. 603-609, 587, 634; A. 527 entire, 549, j35, $e(313, a-f, h)$; B. 308,309 entire, $283,3, b$; H. 585, 586, I, II, $1-3,598$.

\section{Lesson XXIV. Expressions and Constructions of Time}

Time When and Within Which: G. 393, R. 1, 2, 5; A. 423, 424, a $(256,259, a)$; B. $230,1,2,231$; H. 486, 1, 487, $1,2$.

Duration of Time: G. 336, R. 1, 2, 4; A. 423, 2, 424, a (256); B. $181,1,2 ;$ H. 417,1 .

"Before" and "After": G. 403, N. 4. $a-c$; A. 424, $f(259, d)$; B. 357,1 ; H. 488, $1,2$.

Dates: G. pp. 491-492; A. $630-631,424, g(376,259, e)$; B. 371-372; H. 754-755. 



\section{ENGLISH-LATIN VOCABULARY}

\section{(The numbers refer to sections.)}

A

a bandon, leave behind, relinquō, -ere, -līquī, -līetum; dēserō, -ere, -seruī, -sertum; give up, throw away, abiciō, -ere, -iēcî, -iectum.

abide, maneō, -ēre, mānsī, mānsūrus; abide by something, in aliquā rē maneō.

ability, mental ability, ingenium, $-\overline{1}, \quad n$.; ability, excellence, virtūs, -tūtis, $f$.

able (be), possum, posse, potuī, -. With infin.

about, concerning, dē, prep. with abl. case. around, circum, prep. with acc. case; apud, prep. with acc. case; nearly, circiter, $a d v$., used with numerals.

above, suprā, adv. and prep. with acc. case.

abroad, forìs, $a d v$.

absence (in one's), absēns, absentis, adj.; in my absence, mē absente.

absent, absēns, absentis.

absent (be), absum, -esse, āfuī, āfutūrus; . . . ab aliquā rē, from something.

abuse, abūtor, -ūtī, -ūsus sum. Cf. 165. accomplish, cōnficiō, -ere, -fēcī, -fectum; gerō, -ere, gessī, gestum; adsequor, -sequī, -secūtus sum.

accord (of my own, etc.), meā sponte. Cf. 38 .

accordance with (in), dē or ex with the abl., or the abl. alone. Cf. 138-139.

according to, expressed by the abl., with or without dē or ex. Cf. 138-139.

accordingly, itaque; igitur. Cf. 412; quā rē.

account of (on), propter, prep. with acc. case; ob, prep. with acc. case. Cf. 135-136; on my account, meō nōmine; meā sponte.

accuse, accūsō, -āre, -āvī, -ātum. Cf. 121.

accustomed (be), soleō, -ēre, solitus sum; cōnsuēvī. Cf. 209. Also sometimes expressed by the imperfect tense. Cf. 203.

accustomed (become), cōnsuēscō, -ere, -suēvī, -suētum. Cf. 209. achievements, rēs gestae, rērum gestārum, $f . p l$.

Achilles, Achillēs, -is, $m$.

across, trāns, prep. with acc. case. 
across (lead), trādūcō, -ere, -dūxī, -ductum. Cf. 62-63.

act (noun), factum, $-\overline{\mathbf{1}}, n_{\text {.; }}$ gestum, $-\overline{1}, n$.

act (verb), mē gerō. Reflexive verb.

actuate, moveō, -ēre, mōvī, mōtum.

add, addō, -ere, addidī, additum. added to this is the fact that .... accēdit (-ere, accessit) ut ... Cf. 264.

address, speak to, adloquor, -loquī -locūtus sum; appellō, -āre, -āvī, -ātum; address (soldiers, etc.), cohortor, -ārī, -ātus sum. Adiatunnus, Adiatunnus, $-\overline{1}, m$. admire, mīror, -ārī, -ātus sum; admīror, -ārī, -ātus sum. adopt, capiō, -ere, cēpī, captum; ineō, -īre, -ī̄, -itum; cōnstituō, -ere, -stitūi, -stitūtum; adopt a plan, cōnsilium capiō; cōnsilium ineō.

Aduatuci, Aduātucī, -ōrum, m. pl., a tribe of the Belgians.

advance, prōgredior, -gredī, -gressus sum; prōcēdō, -ere, -cessī, -cessum; advance to the attack, sīgna inferō, -ferre, intulī, illātum.

advantage, ūsus, -ūs, $m$.

advantage (be of), interest, -esse, -fuit, -futūrus; rēfert, -ferre, -tulit. Cf. 124-125.

advantageous, dat. of ūsus according to 90 . Cf. also 483, 2. advice, sententia, -ae, $f_{\text {.; }}$ cōnsilium, $-\overline{\mathbf{1}}, n$.

advice (ask), cōnsulō, -ere, -uī, -sultum, with acc. case. Cf, 80. advise, moneō, -ēre, monuī, monitum. Cf. 262, 117.

Aeduan, Aeduus, -a, -um; Aeduus, -ī, m., an Aeduan.

affair, rēs, rēi, $f$.

afraid (be), timeō, -ēre, -uī, vereor, -ērī, veritus sum; metuō, -ere, metuī, -. Cf. 266-268.

Africa, Africa, -ae, $f$.

after, post, adv. and prep. with acc. case; postquam, conj. Cf. 283-284. cum (cf. 284), posteā, $a d v$.

afterward, posteā, $a d v$.

again, a second time, iterum; (back) again, rūrsus.

against, contrā, prep. with acc. case; in, prep. with acc. case. ago, ante; abhinc. Cf. 173-174. two days ago, nūdius tertius. (Indeclinable.)

agree, cōnsentiō, -īre, -sēnsī, -sēnsum; . . . with some one, ... cum aliquō.

ahead (send), praemittō, -ere, -mīsī, -missum.

aid (noun), auxilium, -ī, n.; opera, -ae, $f$.; subsidium, -ī, $n$.

aid (verb), iuvō, -āre, iūvī, (ịūtum); adiuvō, -āre, -iūvī, (-iūtum); adsum, -esse, -fuī, -futūrus. Cf. $80-81$.

Alabama, Alabāma, -ae, $f$.

alarm, commoveō, -ēre, -mōvī, -mōtum; permoveō, -ēre, -mōvī, -mōtum.

Alexander, Alexander, -drī, $m$. alike, similis, -e. Cf. $92,96$.

all, every, omnis, -e; all, the whole, tōtus, -a, -um; ūniversus, -a, -um; cūnctus, -a, -ụm, 
a. (of), commūnis, -e.

a). (not at), nihil, adv. Cf. 74 . A lobroges, Allobrogēs, -um, $m$. pl., a tribe of the Gauls.

a. low, patior, patī, passus sum; sinō, -ere, sīvī, situm. Cf. 329. permittō, -ere, -mīsī, -missum. Cf. 262.

a lowed (it is), licet, licēre, licuit. Cf. $325,3$.

ally, socius, $-\overline{1}, m$.

almost, paene; ferē. Cf. 411. alone, sōlus, -a, -um; ūnus, -a, -um.

along with, ūnā cum, with abl. A.lps, Alpēs, -ium, $f . p l$.

already, iam, $a d v$.

also, etiam; quoque; not only

... but also, nōn modo (sōlum)

.... sed (vērum) etiam.

although, cum ; quamquam ; tametsī, etsī, etiamsī; quamvīs; licet. Cf. 314-322.

altogether, omnīnō, adv.

always, - semper, $a d v$.

ambassador, lēgātus, $-\overline{\mathbf{i}}, m$.

Ambiorix, Ambiorix, -īgis, m., a prince of the Eburones. among, apud, prep. with acc. case; in, prep. with acc. or abl. Cf. in. amount, great number, multitūdō, -dinis, $f$.

ample, amplus, -a, -um.

ancestors, māiōrēs, -um, m. pl. ancestral, patrius, -a, -um. anchor, ancora, -ae, $f$.; at anchor, in ancorā or in ancorīs. ancient, vetus, veteris; antīquus, -a, -um.

and, et; -que; atque, ac. Cf. 394. and so, itaque, igitur. Cf. 412, 1. anger, ira, -ae, $f$.

announce, nüntiō, -āre, -āvī, -ātum.

another, alius, -a, -ud. Cf. 56.

answer (noun), respōnsum, -ī, n.; make answer, respondeō, -ēre, -spondī, -spōnsum.

answer (verb), respondeō, -ēre, -spondī, -spōnsum.

Antioch, Antiochīa, -ae, $f$.

Antonius, Antōnius, $-\overline{1}, m$.

any, ūllus, -a, -um; aliquī, -qua, -quod; quī, qua, quod; any ... however great, quantusvĩs, quanta-, quantum-. Cf. 4656.

any one, anything, aliquis, aliquid; quis, quid; any one at all, anything at all, quisquam, quicquam. Cf. 47-49.

appease, plācō, -āre, -āvī, ātum. appoint, dēligō, -ere, -lēgī, -lēctum; creō, -āre, -āvī, -ātum; cōnstituō, -ere, -stitū̄, -stitūtum; choose as lēgãtus, lēgō, -āre, -āvī, -ātum. Cf. 67-69.

approach (noun), adventus, -ūs, $m$;; aditus, -ūs, $m$.

approach (verb), appropinquō, -āre, -āvī, -ātum; adeō, -īre, -ì̄, -itum.

approve, probō, -āre, -āvī, -ātum. Aquitania, Aquītānia, -ae, $f$.

Aquitanians, Aquītānī, -ōrum, $m$. $p l$.

Archias, Archiās, -ae, $m$.

Archelaus, Archelāus, $-\overline{\mathbf{1}}, m$.

argument, ōrātiō, -ōnis, $f$.

Ariobarzanes, Ariobarzānēs, -is, $m$. 
Ariovistus, Ariovistus, $-\overline{\mathbf{1}}, m$. arise, orior, -īrī, ortus sum; coörior, -īrī, -ortus sum. arm, armō, -āre, -āvī, -ātum; armed men, armātī, -ōrum, m. pl.; light armed, expeditus, -a, -um. Armenia, Armenia, -ae, $f$. arms, arma, -ōrum, $n$. $p l$. army, exercitus, -ūs, m.; the general term; army on the march, āgmen, āgminis, n.; army drawn up in line of battle, aciēs, -ēè, $f$.

around, circum, prep. with acc. case; apud, prep. with acc. case. arouse, commoveō, -ēre, -mōvī, -mōtum; excitō, -āre, -āvī, -ātum; incitō, -āre, -āvī, -ātum. arrange, cūrō, -āre, -āvī, -ātum. Cf. 382 .

arrest, comprehendō, -ere, -hendī, -hēnsum.

arrival, adventus, -ūs, $m$.

arrive, perveniō, -īre, -vēnī, -ventum; adveniō, -īre, -vēnī, -ventum; . . . at, . . . in or ad with acc. case.

art, ars, artis, $f$.

Arverni, Arvernī, -ōrum, m. pl., a tribe of the Gauls.

as, ut, conj. with the indicative; quem ad modum.

as ... as, tam ... quam.

as follows, ita.

as great, tantus, -a, -um; as great as, tantus... quantus.

as (the same), idem qui. Cf. 43. as if, tamquam sī; velutsī; acsī; quasi. Cf. 313.

as long as, dum. Cf. 285 .

as much as, tantus ... quantus. as ... as possible, quam with the superlative.

as soon as, simulatque, simulac; cum prīmum; ut prīmum. Cf. 283.

as soon as possible, quam prīmum. ascend, ascendō, -ere, ascendī, ascēnsum.

ascent, ascēnsus, -ūs, $m$.

Asia, Asia, -ae, f.; of or in Asia, adj., Asiāticus, -a, -um.

Asiatic, Asiāticus, -a, -um.

ask, quaerō, -ere, quaesīvī, quaesītum; rogō, -āre, -āvī, -ātum; petō, -ere, -īvī, -ītum; postulō, -āre, -āvī, -ātum; pōscō, -ere, popōscī, - Cf. 70-72.

ask advice, cōnsulō, -ere, -uī, cōnsultum.

ask for, rogō, -āre, -āvī, -ātum; postulō, -āre, -āvī, -ātum; flāgitō, -āre, -āvī, -ātum. Cf. 70-72.

assassinate, occīdō, -ere, -cīdī, -cīsum; interficiō, -ere, -fēcī, -fectum.

assemble, come together, conveniō, -īre, =vēnī, -ventum; assemble, bring together, comparō, -āre, -āvì, -ātum; condūcō, -ere, -dūxī, -ductum.

assert, praedicō, -āre, -āvī, -ātum; dīcō, -ere, dīxī, dictum; cōnfīrmō, -āre, -āvī, -ātum.

assign, commendō, -āre, -āvī, -ātum; attribuō, -ere, -tribuī, -tribūtum.

assist, iuvō, -āre, iūvī, (iūtum); adiuvō, -āre, -iūvī, (-iūtum); adsum, -esse, -fuī, -futūrus; sublevō, -āre, -āvī, -ātum. 
as: ociate, socius, -ī, m.; comes, omitis, $m$.

as: ure, cōnfīrmō, -āre, -āvī, -ātum. at. Cf. 167, $194 a$.

at all (not at), nihil.

at daybreak, prīmā lūce.

at first, prīmum.

at hand (be), adsum, -esse, -fuī, -futūrus.

Athens, Athēnae, -ārum, $f . p l$.

Atlanta, Atlanta, -ae, $f$. :

at last, tandem; dēmum.

at length, tandem; dēmum.

at once, statim.

Atrebates, Atrebātēs, -um, m. pl. at stake (be), passive of agō, -ere, ēgī, āctum.

attack (noun), impetus, -ūs, m.; oppūgnātiō, -ōnis, $f_{\text {.; }}$ make an attack on some one, in aliquem impetum faciō.

attack (verb), of towns, etc., oppūgnō, -āre, -āvī, -ātum; of persons, petō, -ere, -īvī, -ītum; adgredior, -gredī, -gressus sum; adorior, -īrī, -ortus sum; lacessō, -ere, -īvī, -ītum; impetum in aliquem faciō.

attempt (noun), cōnātus, -ūs, m.; make an attempt, cōnor, -ārī, -ātus sum; temptō, -āre, -āvī, -ātum.

attempt (verb), cōnor, -ārī, -ātus sum; temptō, -āre, -āvī, -ātum. at the foot of, sub, prep. with abl. case.

at the same time, simul; ūnō tempore.

at the time when, tum cum. Cf. 280.

Attius, Attius, $-\overline{1}, m$. attribute, tribuō, -ere, tribuī, tribūtum; dō, dare, dedī, datum. audacity, audācia, -ae, $f$.

Aulus, Aulus, $-\overline{1}, m$. authority, auctōritās, -tātis, $f$. avenge, ulcīscor, ulcīscī, ultus sum.

avert, dēpellō, -ere, -pulī, -pulsum; āvertō, -ere, āvertī, āversum. avoid, vītō, -āre, -āvī, -ātum. await, exspectō, -āre, -āvī, -ātum. aware, cōnscius, -a, -um; aware of something, alicūius reī cōnscius.

away (be), absum, esse, āfuī, āfutūrus; . . . from anything, ... ab aliquā rē.

Axona, Axona, -ae, f., a river of Gaul.

\section{B}

back, tergum, -ī, $n$.

back (get), regain, recuperō, -āre, -āvī, -ātum.

baggage, impedīmenta, -ōrum, $n$. $p l$.

band, manus, -ūs, $f$.

bank, rīpa, -ae, $f$.

barbarian, barbarus, $-\overline{1}, m$.

barbarous, barbarus, -a, -um.

barely, vix, $a d v$.; parvō discrīmine. battle, proelium, -ī, n.; pūgna, -ae, $f$.; begin battle, join battle, engage in battle, proelium committō, -ere, -mīsì, -missum.

battle (field of), aciēs, -ēì, $f$. battle (line of), aciēs, -ēī, $f$.

B.C., ante Chrīstum nātum. Cf. 183-184.

be, sum, esse, fuī, futūrus.

be able, possum, posse, potuī, - 
be absent, absum, -esse, āfuī, āfutūrus.

be accustomed, soleō, -ēre, solitus sum; cōnsuēvī. Cf. 209-210. be afraid, timeō, -ēre, -uī, -; vereor, -ērī, -itus sum; metuō, -ere, metuī, - Cf. 266-268.

be at hand, adsum, -esse, -fuì, -futūrus.

be at the head of, praesum, -esse, -fuī, -futūrus. With dat. case.

be away, absum, -esse, -fuī, āfutūrus.

be distant, absum, -esse, āfuī, āfutūrus.

be dons, fīō, fierī, factus sum.

be eager, cupiō, -ere, -īvī, -ītum. be ignorant of, ignnōrō, -āre, -āvī, -ātum; nesciō, -īre, -īvī (-iī), -ītum.

be in command of, be in charge of, praesum, -esse, -fūi, -futūrus. With dat. case.

be informed, certior fīō, fiẹī, factus sum.

be lacking, dēsum, -esse, -fuī, -futūrus.

be left, supersum, -esse, -fuī, -futūrus.

be made, fīō, fierī, factus sum.

be near, adsum, -esse, -fuī, -futūrus.

be of advantage, prōsum, prōdesse, prōfuī, prōfutūrus.

be present, adsum, -esse, -fuī, -futūrus.

be silent, taceō, -ēre, -uī, -itum.

be to the interest of, interest, -esse, -fuit; rēfert, -ferre, -tulit. Cf. 124-125.

be willing, nōlō, nōlle, nōluī, - - l beginning, initium, -ī, $n$. caritūrus. Cf. 153. be willing, volō, velle, voluī, be without, careō, -ēre, caruī,

beat, vincō, -ere, vīcī, victum.

beautiful, pulcher, pulchra, pulchrum.

because, quod; cum; quoniam; quia. Cf. 291-297.

because of, propter, prep. with acc. case; ob, prep. with acc. case; abl. case. Cf. 135-136. become, fīō, fierī, factus sum.

become accustomed, cōnsuēscō, -ere, cōnsuēvī, cōnsuētum. Cf. 209.

become master of the situation, rërum potior, -īrī, -ìtus sum. Cf. 166.

befall, accidō, -ere, -cidī, -

before, priusquam, conj.; antequam, conj. Cf. 289. ante, adv. and prep. with acc. case. anteā, $a d v$.; ad populum loquor, speak before the people. before (on the day), prīdiē. Cf. $179,2,181$.

before this, anteă, adv.

beg, ōrō, -āre, -āvī, -ātum; rogō, -āre, -āvī, -ātum; petō, -ere, -īvì, -ītum; implōrō, -āre, -āvī, -ātum. Cf. 70-72, 262.

begin, incipiō, -ere, -cēpī, -ceptum; coepī, coeptum. Coepī is found only in the perfect system. When a complementary infinitive dependent on coepi is passive, the passive forms of coepi should be used.

begin battle, proelium committō, -ere, -mīsī, -missum. 
be lalf of (in or on), prō, prep. with abl. case.

be lind, post, prep. with acc. ase.

be 1old, aspiciō, -ere, aspēxī, aspectum.

$\mathrm{B}$ l lgian, Belga, -ae, $m$.

Bi lgium, Belgium, $-\overline{1}, n$.

b $\in$ lieve, crēdō, -ere, crēdidī, crēditum. Cf. 79-80.

Błllovaci, Bellovacī, -ōrum, m. pl.

be sides (this), praetereā, $a d v$.

bı siege, oppūgnō, -āre, -āvī, -ātum; obsideō, -ēre, -sēdī, -sessum.

bestow, mandō, -āre, -āvī, -ātum; dō, dare, dedī, datum.

bestowal. Cf. 368 .

hetake one's self, mē cōnferō, -ferre, -tulī, -lātum.

betake one's self to flight, mē in fugam dō.

better (it is), praestat, -stāre, -stitit.

between, inter, prep. with acc. case.

Bibrax, Bibrax, Bibractis, $f$., $a$ town of the Remi.

bidding, imperātum, $-\overline{1}, n$.

ijirth, nātus, -ūs, $m$.; before the birth of Christ, ante Chrīstum nātum. Cf. 183-184.

jitter, acerbus, -a, -um.

slame, culpa, -ae, $f$.

slock, interclūdō, ere, -clūsī, bring in, īnferō, -ferre, intulī, -clūsum.

soat, nāvis, -is, $f$.

sody, corpus, corporis, $m$.

Boii, Boiī, -ōrum, m. $p l$.

sold, audāx, audācis; fortis, -e.

soldly, audācter, $a d v$.

joldness, audācia, -ae, $f$. book, liber, librī, $m$.

booty, praeda, -ae, $f$.

born (be), nāscor, nāscī, nātus sum.

Bosporus, Bosporus, -ī, m.; people of the Bosporus, Bosporānī, -ōrum, m. pl.

both, uterque, utraque, utrumque. Cf. 55 .

both ... . and, et . . . et; cum ... tum. Cf. $399,280$.

bound, contineō, -ēre, -uī, -tentum. boundary, fīnis, -is, $m$.

boy, puer, puerī, $m$.

boyhood, pueritia, -ae, $f$.

brave, fortis, -e.

bravely, fortiter.

bravery, virtūs, -tūtis, $f$.

break camp, castra moveō, -ēre, mōvī, mōtum.

break out, arise, orior, -īrī, ortus sum; coörior, -īrī, -ortus sum. break up, disiciō, -ere, -iēcī, -iectum.

bribe, sollicitō, -āre, -āvī, -ātum. bridge, pōns, pontis, $m$.

bring, ferō, ferre, tul̄̄, lātum; portō, -āre, -āvī, -ātum.

bring about, efficiō, -ere, -fēcī, -fectum; adsequor, -sequi, -secūtus sum. Cf. 264.

bring forth, bring out, prōferō, -ferre, -tulī, -lātum.

inlātum (illātum); importō, -āre, -āvī, -ātum.

bring to, adferō, -ferre, attulī, adlātum (allātum).

bring to a finish, bring to a conclusion. Cf. finish.

bring to light, illūstrō, -āre, -āvī, 
-ātum; patefaciō, -ere, -fēcī, -factum.

bring together, cōnferō, -ferre, -tulī, -lātum (collātum); comportō, -āre, -āvī, -ātum.

Britain, Britannia, -ae, $f$. , England.

Briton, Britannus, $-\overline{1}, m$.

broad, lātus, -a, -um.

brother, frāter, frātris, $m$.

Brundisium, Brundisium, $-\overline{1}$, n., a city of Italy.

build, aedificō, -āre, -āvī, -ātum; faciō, -re, fēcī, factum.

building, aedificium, $-\overline{\mathrm{i}}, \boldsymbol{n}$.

burn, incendō, -ere, incendĩ, incēnsum.

burning, incendium, $-\overline{\mathbf{l}}, n$. Cf. also 368 .

burst forth, ērumpō, -ere, -rūpī, -ruptum.

business, negōtium, -ī, $n$.

busy (keep), occupō, -āre, -āvī, -ātum.

but, sed; autem. Cf. 397, 412. at; but also, sed (vērum) etiam. but if, sīn. Cf. 299, 3 .

by, of a person, $\overline{\mathrm{a}}$ or ab with abl. case; otherwise the abl. without a prep. Cf. 127-130.

by far, longē, $a d v$.

\section{C}

Caesar, Caesar, Caesaris, $m$. calamity, calamitās, -tātis, $f$. call, call by name, appellō, -āre, -āvī, -ātum; nōminō, -āre, -āvī, -ātum; summon, call, vocō, -āre, -āvī, -ātum. Cf. 58, 67-69. call aside, dēvocō, -āre, -āvī, -ātum. call together, convocō, -āre, -āvī, -ātum.

camp, castra, -ōrum, n. $p l$; pitch camp, castra pōnö, -ere, posuī, positum; castra locō, -āre, -āvī, -ātum; break camp, castra moveō, -ēre, mōvī, mōtum.

can, possum, posse, potuī, -

cancellation of debts, novae tabulae, novārum tabulārum, $f . p l$. captive, captĩvus, $-\overline{1}, m$.

capture, of towns, etc., expūgnō, -āre, -āvī, -ātum; general term, capiō, -ere, cēpì, captum.

Carbo, Carbō, -ōnis, $m$.

care, cūra, -ae, $f$; dīligentia, -ae, f.; foresight, prūdentia, -ae, $f$.

careful, dīligēns, -gentis.

carefully, dìligenter.

carry, ferō, ferre, tulī, lātum; portō, -āre, -āvī, -ātum; carry (to), adferō, -ferre, attulī, adlātum (allātum).

carry on, gerō, -ere, gessī, gestum. carry out, cōnficiō, -ere, -fēcī, -fectum; cōnsequor, -sequī, -secūtus sum; carry out commands, iūssa (imperāta) faciō.

Carthage, Carthāgō, -ginis, $f ., a$ city of Africa.

Carthaginian, Carthāginiēnsis, -is, m., a citizen of Carthage.

case, causa, -ae, $f_{\text {.; }}$ rēs, reī, $f$.; plead a case ; causam dīcō.

case (this being the), quae cum ita sint.

Cassius, Cassius, $-\overline{1}, m$.

cast out, èiciō, -ere, èiēcī, èiectum.

Casticus, Casticus, $-\mathbf{i}, m$. 
c tch, capiō, -ere, cēpī, captum.

c ıtch sight of, cōnspiciō, -ere, -spēxī, -spectum; cōnspicor, -ārī, -ātus sum.

(atiline, Catilina, -ae, $m$.

(ato, Catō, -ōnis, $m$.

( atulus, Catulus, $-\overline{1}, m$. (ause, causa, -ae, $f$.; plead one's cause, causam dīcō.

( avalry, equitātus, -ūs, $m$.; equitēs, -um, m. pl.

(ease, dēsistō, -ere, -stitī, -; dēsinō, -ere, -sīvī, -situm.

celebrate, celebrō, -āre, -āvī, -ātum; celebrate a triumph over some one, dē aliquō triumphō, -āre, -āvī, -ātum.

Celts, Celtae, -ārum, m. pl.

censor, cēnsor, -ōris, $m$.

centurion, centūriō, -ōnis, $m$.

certain, a certain, quīdam, quae-

dam, quiddam. Cf. 51. certain, fixed, certus, -a, -um.

Cethegus, Cethēgus, $-\overline{\mathbf{1}}, m$. chain, vinculum, $-\overline{1}, n . ;$ in chains, ex vinculiss.

chance, opportunity, facultās, -tātis, f.; chance, fortune, cāsus, -ūs, $m$.

change (noun), commūtātiō, -ōnis, $f$.

change (verb), mūtō, -āre, -āvī, -ātứm; commūtō, -āre, -āvī, -ātum; convertō, -ere, -vertī, -versum.

character (of such a), ēius modī. Cf. 102, 275, 4 .

charge (be in), praesum, -esse, -fuī, -futūrus. With dat. case. Cf. 83.

charge (place or put in), prae-l cohort, cohors, cohortis, $f$. ficiō, -ere, -fēcī, -fectum. Cf. 84.

check, reprimō, -ere, -pressī, -pressum; opprimō, -ere, -pressī, -pressum; retardō, -āre, -āvī, -àtum.

check (hold in), coerceō, -ēre, -uī, -itum.

chief, prīnceps, prīncipis, $m$. children, līberī, -ōrum, m. pl.; puerī, -ōrum, m. pl.

choice. Use the verb choose.

choose, dēligō, -ere, -lēgī, -lēctum.

Christ, Christus, -ī, m.; before the birth of Christ, ante Chrīstum nātum. Cf. 182-184.

Cicero, Cicerō, -önis, $m$.

Cilicia, Cilicia, -ae, $f .$, a country of Asia Minor.

Cincinnati, Cincinnātī, -ōrum, $m$. $p l$.

circumstances (under these), quae cum ita sint.

citizen, civis, -is, $m$. and $f$.

citizens (fellow-), Quīrītēs, -ium, $m$. pl.; my fellow-citizens, meì' cìvēs.

citizenship, cīvitās, -tātis, $f$. city, urbs, urbis, $f$.

city-, of the city, in the city, adj., urbānus, -a, -um.

civil, cīvilis, -e; domesticus, -a, -um.

class, genus, generis, n.; ōrdō, ördinis, $m$.

clear, clārus, -a, -um; manifēstus, -a, -um.

client (my), use hīc.

coast, öra, -ae, $f_{\text {.; }}$ o ora maritima, sea coast. 
colleague, collēga, -ae, $m$.

collect, cōgō, -ere, coēgī, coāctum; colligō, -ere, -lēgī, -lēctum; collect an army, exercitum comparō, -āre, -āvī, -ātum; collect revenues, vectīgālia exigō, -ere, exēgī, exāctum. come, veniō, -īre, vēnī, ventum. come forth, prōgredior, -gredī, -gressus sum.

come on, approach, adeō, -îre, -iī, -itum.

come together, conveniō, -īre, -vēnī, -ventum.

come (up) to, accēdō, -ere, -cessī, -cessum; perveniō, -īre, -vēnī, -ventum.

come up, succēdō, -ere, -cessī, -cessum.

coming, adventus, -ūs, $m$.

command (noun), imperium, -ī, n.; iūssus, -ūs, m.; iūssum, -ī, n.; mandātum, $-\overline{1}, n . ;$ at the command, iūssū; without the command, iniūssū. Cf. 139.

command (verb), imperō,- āre, -āvī, -ātum. Cf. 79-82, 262; iubēō, -ēre, iūssī, iūssum. Cf. 81, 263, 332. mandō, -āre, -āvī, -ātum. Cf. 262.

command (be in), praesum, -esse, -fuī, -futūrus. With dat. case. Cf. 83.

command (place or put in), praeficiō, -ere, -fēcī, -fectum. Cf. 84.

commander, imperātor, -ōris, $m$. commence battle, proelium committō, -ere, -mīsī, -missum.

commit, committō, -ere, -mīsī, -missum.
Commius, Commius, $-\bar{i}, m$.

common, commūnis, -e.

companion, comes, comitis, m.; socius, $-\overline{1}, m$.

compare, cōnferō, -ferre, -tulī, -lātum (collātum).

compel, cōgō, -ere, coēgī, coāctum.

complain, queror, querī, questus sum.

complete, peragō, -ere, ēgī, -āctum; perficiō, -ere, -fēcī, -fectum.

comrade, socius, $-\bar{i}, m$.

conceal, cēlō, -āre, -āvĩ, -ātum. Cf. 70 .

concern, cūrae est. Cf. 90-91; pertineō, -ēre, -tinuī, -tentum, with ad and acc.

concerning, dē, prep. with abl. case.

concerns (it), interest, -esse, -fuit; rēfert, -ferre, -tulit. Cf. 124125 .

condemn, damnō, -āre, -āvī, ātum. Cf. 121 .

condition, condiciō, -ōnis, $f$.

conduct (noble), virtūs, -tūtis, $f$. conduct, manage, administrō, -āre, -āvī, -ātum; gerō, -ere, gessī, gestum.

conduct a trial, iūdicium exerceō, -ēre, -uī, -itum.

conduct one's self, act, mē gerō, -ere, gessī, gestum.

confer, bestow, tribuō, -ere, tribuī, tribūtum; dēferō, -ferre, -tulī, -lātum; concēdō, -ere, -cessī, -cessum.

confer, talk with, colloquor, -loquī, -locūtus sum. 
cor ference, colloquium, -ī, n.; ( oncilium, $-\bar{i}, n$.

co1 fess, cōnfiteor, -ērī, -fessus : um; fateor, -ērī, fassus sum. cor fine, contineō, -ēre, -tinuī, tentum.

cos fusion (throw into), perturbō, āre, -āvī, -ātum.

co: unect, hold together, contineō, ēre, -tinuī, -tentum.

co aquer, vincō, -ere, vīcī, victum; superō, -āre -āvī, -ātum.

conqueror, victor, -ōris, $m$.

conscious, cōnscius, -a, -um. With gen. case. Cf. 113-114.

conscript fathers, patrēs cōnscrīptī, patrum cōnscrīptōrum, m. $p l$.

consent, voluntās, -tātis, $f$.; without my consent, mē invitō: consider, judge, iūdicō, -āre, -āvī, -ātum; habeō, -ēre, -uī, -itum; dūcō, -ere, dūxī, ductum; exīstimō, -āre, -āvī, -ātum; putō, -āre, -āvī, -ātum; consider, deliberate, cōnsīderō, -āre, -āvī, -ātum; dèlīberō, -āre, -āvī, -ātum.

zonsideration (a matter for), cūra, -ae, $f$.

consideration (leave out of), omittō, -ere, -mīsī, -missum.

Considius, Cōnsidius, $-\overline{1}, m$.

conspiracy, coniūrātiō, -ōnis, f.; form a conspiracy, coniūrātiōnem faciō.

conspirator, coniūrātus, $-\overline{\mathbf{1}}, m$. conspire, coniūrō, -āre, -āvī, -ātum. construct, faciō, -ere, fēcī, factum; aedificō, -āre, -āvī, -ātum. consul, cōnsul, -is, $m$. consulship, cōnsulātus, -ūs, m.; in the consulship of ... Cf. $370,371$.

consult, cōnsulō, -ere, -uī, -tum. With acc. Cf. 80.

consult the interest of, consult for, cōnsulō, -ere, -uī, -tum. With dat. Cf. 79-80.

contend, contendō, -ere, -tendī, -tentum.

contest, certāmen, certāminis, $n$. contrary to, contrā, prep. with acc. case.

contribute, cōnferō, -ferre, -tulī, -lātum (collātum).

control (noun), imperium, $-\overline{1}, n$. ; iūs, iūris, $n$.; potestās, -tātis, $f$. control (verb), contineō, -ēre, -tinuī, -tentum; coerceō, -ēre, -uī, -itum; regō, -ere, rēxī, rēctum.

control (get), potior, -īrī, -îtus sum. Cf. 165-166, 125.

Corinth, Corinthus, $-\overline{1}, f$.

Cornelius, Cornēlius, $-\overline{1}, m$.

Cotta, Cotta, -ae, $m$.

council, concilium, -ī, n.; conventus, -ūs, $m$.

country, the general term, terra, -ae, $f$.; country, land, territory, fīnēs, -ium, m. pl.; as opposed to the city, rūs, rūris, $n$. Cf. 194. native land, patria, -ae, $f$. courage, virtūs, -tūtis, $f$.

courageous, fortis, -e. court, iūdicium, $-\overline{1}, n$.

cover, compleō, -ēre, -ēvī, -ētum. Crassus, Crassus, $-\overline{1}, m$.

Cretan, Crētēnsis, -e; a Cretan, a citizen of Crete, Crētēnsis, -is, $m$. 
crime, scelus, sceleris, $n$.; facinus, facinoris, $n$.

criminal, scelerātus, -ī, m.; facinorōsus, $-\overline{1}, m$.

crisis, difficile tempus, difficilis

temporis, $n$.

cross, trānseō, -īre, -ī̄, -itum.

crowded together, cōnfertus, $-a$, -um.

cruel, crūdēlis, -e.

cruelly, crūdēliter.

cruelty, crūdēlitās, -tātis, $f$.

crush, opprimō, -ere, -pressī,

-pressum; comprimō, -ere, -pressī, -pressum.

cry, clāmor, -ōris, $m$.

culture, hūmānitās, -tātis, $f$.

Cumae, Cūmae, -ārum, $f . p l$., a city of Italy.

Cures, Cūrēs, -ium, $f \cdot p l$., a town of the Sabines.

Curio, Cūriō, -ōnis, $m$.

custody, cūstōdia, -ae, $f$.

custom, mōs, mōris, m.; cōn-

suētūdō, -dinis, $f$.

cut down, concīdō, -ere, -cīdī, -cīsum; occīdō, -ere, -cīdī,

-cīsum.

cut off, interclūdō, -ere, -clūsī, -clūsum.

\section{D}

daily ( $a d v$.$) , cotīdiē; in diēs.$ daily ( $a d j$. ), cotīdiānus, -a, -um. danger, perīculum, $-\overline{1}, n$. dangerous, perīculōsus, -a, -um. dare, audēo, -ēre, ausus sum. daring (noun), audācia, -ae, $f$. daring (adj.), audāx, audācis. daughter, fīlia, -ae, $f$. day, diēs, diēī, $m$. and $f$. day (each), cotīdiē; in diēs.

day (on the preceding), prīdiē. Cf. $179,2,181$.

day before (on the), prīdiē. Cf. $179,2,181$.

day before yesterday (on the), nūdius tertius (indecl.).

daybreak, daylight, prīma lūx;

at daybreak, prīmā lūce.

dead, mortuus, -a, -um.

dear, cārus, -a, -um.

death, mors, mortis, $f_{\text {.; }}$ caedēs, -is, $f$.

death (punish with), morte multō, -āre, -āvī, -ātum.

death (put to), interficiō, -ere, -fēcī, -fectum. Cf. kill.

death penalty, caput, capitis, $n$. debt, aes aliēnum, aeris aliēnī, $n$. deceive, fallō, -ere, fefellī, falsum. decide, cōnstituō, -ere, -stituī, -stitūtum; statuō, -ere, statuī, statūtum; iūdicō, -āre, -āvī, -ātum.

decision, iūdicium, $-\overline{1}, n$.

declare, cōnfīrmō, -āre, -āvī, -ātum; dīcō, -ere, dīxī, dictum.

decree (noun), cōnsultum, -ī, n.; dēcrētum, $-\overline{1}, n$; decree of the senate, senātūs cōnsultum. decree (verb), dēcernō, -ere, -crēvī, -crētum; cēnseō, -ēre, -uī, cēnsum. Cf. 262.

decree (pass a), dēcernō, -ere, -crēvī, -crētum.

deed, factum, $-\overline{1}, n$.

deep, altus, -a, -um.

deeply (how), quam vehementer; quantopere.

defeat, vincō, -ere, vīcī, victum; superō, -āre, -āvī, -ātum. 
d sfend, dēfendō, -ere, -fendī, -fēnsum; tueor, -ērì, tūtus sum. d sfender, dēfēnsor, -ōris, $m$. $\mathrm{d}$ zfense of (in), prō, prep. with abl. case.

$c$ egree (in the highest), summus, -a, -um.

celay (noun), mora, -ae, $f$. celay (verb), moror, -ārī, -ātus sum; cunctor, -ārī, -ātus sum. celiberation(s), cōnsilium, -ī, n. c elight, dēlectō, -āre, -āvī, -ātum. celiver a speech, ōrātiōnem habeō, -ère, -uĩ, -itum.

clemand, postulō, -āre, -āvī, -ātum; pōscō, -ere, popōscī, -; flāgitō, -āre, -āvī, -ātum; demand, make requisition on, imperō, -āre, -āvī, -ātum. Cf. 80. deny, negō, -āre, -āvī, -ātum. 335 .

depart, proficīscor, -ī, profectus sum; discēdō, -ere, -cessī, -cessum; excēdō, -ere, -cessī, -cessum; exeō, -īre, -iī, -itum; abeō, -īre, -īi, -itum; ēgredior, ēgredī, ēgressus sum.

departure, profectiō, -ōnis, $f$.; discessus, -ūs; $m$. deplore, doleō -ēre, -uī, -itum. deprive, prīvō, -āre, -āvī, -ātum; spoliō, -āre, -āvī, -ātum. Cf. 149. deprived (be), careō, -ēre, - - prīvor, -ārī, -ātus. Cf. 149, 153. depth, altitūdō, -dinis, $f$.

descend, dēscendō, -ere, -scendī, -scēnsum.

deserve, mereor, -ērī, -itus sum; mereō, -ère, -uī, -itum; he is worthy to, dīgnus est quī .... Cf. $275,1,569$. deservedly, meritō, adv. deserving, dignus, -a, -um. design, cōnsilium, $-\overline{\mathbf{1}}, \dot{n}$. desire (noun), cupiditās, -tātis, $f$.; studium; $-\overline{1}, \quad n$. ; voluntãs, -tātis, $f$.

desire (verb), volō, velle, voluī, - ; cupiō, -ere, -īvī, -ītum; studeō, -ēre, -uĩ, 一.

desirous, cupidus, -a, -um; appetēns, -entis. Cf. 113-114. be desirous. Cf. desire.

desist, dēsinō, -ere, -sīvī, -situm; dēsistō, -ere, -stitī, - Cf. $148,329$.

despair, dēspērō, -āre, -āvī, -ātum. desperate, perditus, -a, -um; dèspērātus, -a, -um.

despise, contemnō, -ere, -tempsī, -temptum.

despoil, spoliō, -āre, -āvī, -ātum. Cf. 149.

destroy, dēleō, -ēre, -ēvī, -ētum; of persons, interficiō, -ere, -fēcī, -fectum; tollō, -ere, sustulī, sublātum.

destruction, perniciēs, -ēî, $f$.; exitium, $-\overline{1}, n$. ; interitus, -ūs, $m$. deter, dēterreō, -ēre, -uĩ, -itum. Cf. 269-271.

determine, determine on, cōnstituō, -ere, -stitūi, -stitūtum.

devastate, vāstō, -āre, -āvī, -ātum. devote, cōnferō, -ferre, -tulī,-lātum. die, morior, morī, mortuus sum. differ, differō, -ferre, distulī, dīlātum.

different, alius, -a, -ud.

difficult, difficilis, -e.

difficulty, difficultās, -tātis, $f_{\text {.; }}$; with difficulty, aegrē, vix. 
dignity, dīgnitās, -tātis, $f$. diligence, dïligentia, -ae, $f$. diligent, vigilāns, -antis; dīligēns, -entis.

diligently, dīligenter.

diminish, minuō, -ere, minuī, minūtum. For the intransitive use minuo in the pass.

direct, praecipiō, -ere, -cēpī, -ceptum.

direction, pars, partis, $f$. disagree, dissentiō, -îre, -sēnsī, -sēnsum.

disaster, calamitās, -tātis, $f$.

discover, comperiō, -īre, comperī, -pertum; reperiō, -īre, repperī, -pertum; dēprehendō, -ere, -prehendī, -prehēnsum.

discuss, colloquor, -loquī, -locūtus sum; agō, -ere, ègī, āctum.

disembark, (nāvī) ēgredior, ègredī, ēgressus sum.

disgrace, turpitūdō, -dinis, $f_{\text {. }}$; dēdecus, -oris, $n$.

disgraceful, turpis, -e. disgracefully, turpiter. disgust, taedet, taedēre, taeduit. Cf. 118.

dismiss, dīmittō, -ere, -mīsī, -missum.

disorder, tumultus, -ūs, $m$.

disorder (throw into), perturbō, -āre, -āvī, -ātum.

dispatch, a letter, litterae, -ārum, f. $p l$.

dispatch, speed, celeritās, -tātis, $f$. display, ostendō, -ere, -tendī, -tentum.

disposed (ill-), inimīcō animō. disposed (well-), bonō animō. Cf. 140.

dispute, contrōversia, -ae, $f$.

disregard, neglegō, -ere, -lēxī, -lēctum.

distance (at a, from a), procul, $a d v$. distance (be at a), $\left\{\begin{array}{c}\text { absum, -esse, } \\ \bar{a} f u \overline{,}, \overline{a f u}\end{array}\right.$ distant (be),

distinction, honor, -ōris, $m$.; beneficium, $-\overline{1}, n$.

distinguished, īnsīgnis, -e.

district, regiō, -ōnis, $f$.

disturb, perturbō, -āre, -āvī, -ātum.

disturbance, tumultus, -ūs, m.; mōtus, -ūs, m.; dissēnsiō. -ōnis, $f$.

ditch, fossa, -ae, $f$.

Diviciacus, Dīviciācus, $-\overline{\mathbf{1}}, m$.

Divico, Dīvicō, -ōnis, $m$.

do, faciō, -ere, fēcī, factum; agō, -ere, ēgī, āctum.

do harm, noceō, -ēre, -ū, -itum. do not, don't in prohibitions, nōli (sing.); nōlīte ( $p l$.$) . Cf. 240-$ 241.

do one's duty, satisfaciō, -ere, -fēcī, -factum.

doubt (noun), dubium, -ī, $n$. ; be in doubt, dubitō, -āre, -āvī, -ātum. Cf. 272 . be in great doubt, māgnopere dubitō.

doubt (verb), dubitō, -āre, -à̀vī, -ātum. Cf. 272.

down from, dē, prep. with abl. case. draw a sword, gladium ēdūcō, -ere, -dūxī, -ductum; gladium dēstringō, -ere, -strīnxī, -strīctum.

draw up, instruō, -ere, -strū $\bar{i}$, -strūctum. 
d ead, metus, -ūs, $m$.

d ive, pellō, -ere, pepulī, pulsum.

đ:ive back, repellō, -ere, -pulī, -pulsum.

$\mathrm{d}$ rive forth, drive out, drive from, expellō, -ere, -pulī, -pulsum; èiciō, -ere, -iēcī, -iectum.

I umnorix, Dumnorix, -igis, $m$. c uring, expressed by the acc. or the abl. according to 168-169. c.uty, officium, $-\overline{1}, \quad n . ;$ mūnus, mūneris, n.; perform or do one's duty, satisfaciō, -ere, -fēcī, -factum; officiō fungor, fungī, fūnctus sum.

dwell, habitō, -āre, -āvī, -ātum; incolō, -ere, -coluī, -. Cf. live.

dwelling, aedificium, $-\overline{\mathbf{1}}, n$.

dwelling-place, domicilium, $-\overline{1}, n$. sēdēs, -is, $f$.

\section{$\mathrm{E}$}

each, quisque, quaeque, quidque. Cf. 53-55. uterque, utraque, utrumque. Cf. 55 .

each day, cotīdiē; in diēs.

each one, quisque, quaeque, quidque. Cf. 53-55.

each other. Cf. 26.

eager, cupidus, -a, -um; appetēns, -entis. Cf. 113-114. eager (be), cupiō, -ere, -īvī, -ītum. eagerness, studium, $-\overline{\mathbf{i}}, n$.

early, mātūrus, -a, -um.

early (in the morning), māne, $a d v$.

early manhood, aetās inita, aetātis initae, $f$.

early summer, prīma aestās, prīmae aestātis, $f$. earth (the), orbis terrae, orbis terrārum. (Orbis, -is, m.)

easily, facile.

easy, facilis, -e.

effort, labor, -ōris, m.; studium, $-\bar{i}, n$.

eight, octō, indecl. numeral.

eight hundred, octingentī, -ae, $-a, p l$.

eighteenth, duodēvīcēsimus, -a, -um.

eighth, octāvus, -a, -um.

either, aut; vel; either . . . or, aut ... aut; vel ... vel. Cf. 398399.

elapse, passive of intermittō, -ere, -mīsī; -missum.

elate, efferō, efferre, extulī, èlātum; elated, èlātus, -a, -um.

elect, creō, -āre, -āvī, -ātum; dēligō, -ere, -lēgī, -lēctum. Cf. $58,67-68$.

else, alius, $-\mathrm{a},{ }^{\circ}-\mathrm{ud}$.

embassy, lēgātiō, -ōnis, $f$. .

empire, imperium, $-\overline{1}, n$.

employ, negōtium dō, dare, dedī, datum; ūtor, ūtī, ūsus sum. enable, make it possible, efficiō, -ere, -fēcī, -fectum ut... Cf. 264.

encamp, castra pōnō, -ere, posuī, positum.

enclose, inclūdō, -ere, -clūsī, -clūsum.

encourage, cohortor, -ārī, -ātus sum.

end, fīnis, -is, $m$.

end of, extrēmus, -a, -um. Cf. 108.

endowed, praeditus, -a, -um.

endurable, ferendus, $-a,-u m$. 
endure, subeō, -īre, -iī, -itum; perferō, -ferre, -tulī, -lātum; ferō, ferre, tulī, lātum.

enemy, public enemy, hostis, -is, $m$.; personal enemy, inimīcus, $-\overline{1}, m$. energy, zeal, studium, $-\overline{\mathbf{i}}, \boldsymbol{n}$. engage in, gerō, -ere, gessī, gestum; engage in battle, proelium committō, -ere, -mīsī, -missum.

engaged (be), versor, -ārī, -ātus sum.

enjoin, sanciō, -īre, sānxī, sānctum. Cf. 262.

enjoy, fruor, fruī, frūctus sum; ūtor, ūtī, ūsus sum. Cf. 165. enjoyment, frūctus, -ūs, m.; dēlectātiō, -ōnis, $f$.

enmity, inimīcitia, -ae, $f$.; invidia, -ae, $f$.

enough, satis, adv. and indecl. noun. Cf. 104-105.

enroll, of soldiers, cōnscrībō, -ere, -scrīpsī, -scrīptum; enroll as a citizen, ascrībō, -ere, ascrīpsī, ascrīptum; enroll in the census list, cēnseō, -ēre, cēnsuī, cēnsum enter, ineō, -īre, -iī, -itum; intrō, -āre, -āvī, -ātum.

enter upon, take up, suscipiō, -ere, -cēpī, -ceptum.

entertain an opinion or sentiment, sentiō, -īre, sēnsī, sēnsum.

entire, tōtus, -a, -um; ūniversus, -a, -um; cūnctus, -a, -um.

entrust, mandō, -āre, -āvī, -ātum; commendō, -āre, -āvī, -ātum; committō, -ere, -mīsī, -missum; permittō, -ere, -mīsī, -missum; attribuō, -ere, -tribuī, -tribūtum; dēferō, -ferre, -tulī, -lātum. envoy, lēgātus, $-\overline{1}, m$.

equal, pār, paris; aequus, -a, -um. Cf. 92.

equip (a ship), armō, -āre, -āvī, -ātum; ōrnō, -āre, -āvī, -ātum. escape, effugiō, -ere, -fūgī, -fugitum; mē ēripiō, -ere, -ripuī, -reptum; vītō, -āre, -āvī, -ātum. escape the notice, lateō, -ēre, -uī, - With acc. of the person.

especially, praesertim; māximē; ante omnēs; potissimum.

establish, cōnstituō, -ere, -stituī, -stitūtum.

Etruria, Etrūria, -ae, f., district of Italy.

even, $a d v$., etiam; intensive pron., ipse, -a, -um. Cf. 38.

even (not), nē . . quidem. Cf. 412,2 .

even if, etiamsī; etsī; tametsī. Cf. 322 .

even though, etsī; etiamsī, tametsī. Cf. 322.

even up to, ùsque ad with acc. case. evening, vesper, vesperī (or vesperis), $m$.

ever, umquam.

every, all, omnis, -e; quisque, quaeque, quidque. Cf. 53-55. every day, cotīdiè; in diēs.

every one, omnēs, -ium, $m$. and f. $p l$.

every year, quotannīs, $a d v$. everything, omnia, -ium, n. $p l$. evidence, indicium, $-\overline{1}, n$. evil, adj., malus, -a, -um; nefārius, -a, -um; improbus, -a, -um.

evil (noun), malum, -ī, $n$. Cf. 3 . maleficium, $-\mathbf{i}, n$. 
c: il deed, facinus, -oris, $n . ;$ maleficium, $-\overline{1}, n$.

e :cel, antecellō, -ere, -, 一; excellō, -ere, (excelluī), excelsum; superō, -āre, -āvī, -ātum. e icept, praeter, prep. with acc. case; nisi.

e sceptional, ēgregius, -a, -um.

e schange, inter nōs damus, etc. Cf. 26.

execute, administrō, -āre, -āvī, -ātum; faciō, -ere, fēcī, factum. exhausted, cōnfectus, -a, -um. exhort, cohortor, -ārī, -ātus sum. exile (verb), expellō, -ere, -pulī,

-pulsum; ēiciō, -ere, èiēcī, èiectum.

exile, a man banished, exsul, -is, $m$. exile, banishment, exsilium, $-\bar{i}, n$. expect, exspectō, -āre, -āvī, -ātum;

spērō, -āre, -āvī, -ātum. expel, expellō, -ere, -pulī, -pulsum; ēiciō, -ere, èiēcī, èiectum. Cf. drive out.

experience, ūsus, - $\bar{s}, m$.

experienced, perītus, $-\mathrm{a},-\mathrm{um}$. 113.

explain, prōpōnō, -ere, -posuī, -positum; doceō, -ēre, -ūi, doctum; expōnō, -ere, -posuī, -positum.

exploits, rēs geståe, rērum gestārum, $f . p l$.

explore, explōrō, -āre, -āvī, -ātum. expose, obiciō, -ere, -iēcī, -iectum. express an opinion, sententiam

ferō, ferre, tulī, lātum. extemporaneously, ex tempore. extend, pateō, -ēre, -uĩ, extend thanks, grātiās agō, -ere, ēgī, āctum. extol, tollō, -ere, sustulī, sublātum. extraordinary, singulāris, -e; însīgnis, -e.

extremity, extrēma fortūna, extrēmae fortūnae, $f$;; extrēmus cāsus, extrēmī cāsūs, $m$.

eye, oculus, $-\overline{1}, m$.

\section{F}

face about (of an army), signa convertō, -ere, -vertī, -versum; of persons, mē convertō, -ere, -vertī, -versum.

facing, adversus, -a, -um. Cf. 92. fact, rēs, reī, $f$.

fail, dēficiō, -ere, -fēcī, -fectum. With acc. dēsum, -esse, -fuī, -futūrus. With dat.

fall, cadō, -ere, cecidī, cāsum.

fall back, retreat, pedem referō, -ferre, rettulī, relātum.

familiar (with), perītus, -a, -um.

Cf. 113-114.

famous, praeclārus, $-a,-u m$; that famous, ille, -a, -ud. Cf. 34.

far, by far, longē; multō.

farm the taxes, exerceō, -ère, -uī, -itum.

farther (away), amplius; longius. Cf. 159.

farther, adj., ulterior, -ius.

fate, fātum, $-\overline{\mathbf{1}}, n$.

father, pater, patris, $m$.

favor (noun), grātia, -ae, $f . ; \quad$ a kindly act, beneficium, $-\overline{1}, n$.

favor (verb), faveō, -ēre, fãvī, fautum. Cf. 79-80.

favor of (in), prō, prep. with abl. case.

favorable, aequus, -a, -um; secundus, $-a,-u m$. 
fear (noun), metus, -ūs, m.; timor, -ōris, $m$.

fear, verb, timeō, ēre, uī, vereor, -ērī, -itus sum; metuō, -ere, metuī, - C. Cf. 266-267.

feel grateful, grātiam habeō, -ēre, -uĩ, -itum. With dat. case.

fellow-citizens, Quīrītēs, -ium, $m$. $p l . ;$ my fellow-citizens, meī cīvēs.

fertility, fertilitās, -tātis, $f$.

few, paucī, -ae, -a, $p l$.

field, ager, agrī, $m$.

field of battle, aciēs, -ēì, $f$.

field of war (in the), militiae. Cf. 196.

fierce, ācer, ācris, ācre; ferus, $-a,-u m$.

fiercely, ācriter.

fifteen, quīndecim, indecl. numeral. fifth, quīntus, -a, -um.

fifty, quīnquāgintā, indecl. $n u-$ meral.

fight (noun), pūgna, -ae, $f$.; proelium, $-\overline{1}, n$.

fight (verb), pūgnō, -āre, -āvī, -ātum; dīmicō, -āre, -āvī, -ātum.

fight it out, dēcertō, -āre, -āvì, -ātum.

fill, compleō, -ēre, -ēvì, -ètum.

finally, tandem; dēmum; postrēmō; ad extrēmum, dēnique. find, inveniō, -îre, -vēnī, -ventum; reperiō, -ire, repperī, repertum. find out, cōgnōscō, -ere, cōgnōvī, cōgnitum; reperiō, -îre, repperī, repertum.

finish, bring to a finish, cōnficiō, -ere, -fêcī, -fectum; peragō, -ere, -ēgī, -āctum; perficiō, -ere, -fēcī, -fectum; fīnem faciō, -ere, fēcī, factum. fire, ignis, -is, m.; incendium, $-\bar{i}, n$.

fire brand, fax, facis, $f$.

first, $a d j$. , prīmus, -a, -um; adv., prīmum; at first, prīmō; in the first place, primum; principiō; for the first time, prīmum; first part of, prīmus, -a, -um. Cf. 108.

fit, idōneus, -a, -um; fit, ready, parātus, -a, -um.

five, quīnque, indecl. numeral.

fix, locō, -āre, -āvī, -ātum; fix, settle, decide on, cōnstituō, -ere, -stituī, -stitūtum.

fixed, certus, $-a,-u m$.

Flaccus, Flaccus, $-\overline{1}, m$.

flee, fugiō, -ere, fūgī, fugitum.

flee back, refugiō, -ere, -fūgī, -fugitum.

flee (for refugt), cōnfugiō, -ere, -fūgī, -fugitum.

fleet, classis, -is, $f$.

flight, fuga, -ae, $f$.

flight (put to), fugō, -āre, -āvī, -ātum; in fugam dō, dare, dedī, datum; in fugam coniciō, -ere, -iēcīi, -iectum.

flower, flōs, flōris, $m$.

fluency, cōpia, -ae, $f$.

follow, sequor, sequī, secūtus sum.

follower, socius, -ī, m.; comes, comitis, $m$.

following, posterus, -a, -um; proximus, -a, -um; on the following day, posterō diē; proximō diē; postrīdiē ēius diēie.

follows (as), ita; he spoke as follows, haec dixit. Cf. 65 . folly, àmentia, -ae, $f$; the height of folly, summa āmentia. 
fı nd, cupidus, -a, -um; studiōsus -a, -um. Cf. 113-114.

f. od, cibus, $-\overline{1}, m$.

f olish, stultus, -a, -um.

f ot, pēs, pedis, m.; at the foot of, sub, prep. with abl.; to the foot of, sub, prep. with acc. f sothold (get a), īnsistō, -ere, -stitī, -; get a firm foothold, fīrmiter insistō.

foot-soldier, pedes, peditis, $m$. for (conj.), nam; enim. Cf. 412, 1. for (prep.), ad, prep. with acc. case; dat. case; acc. of extent (cf. $169,199)$; in behalf of, in defense of, prō, prep. with abl. case; with verbs of feeling, ergā or in, preps. with acc. case. Cf. 112. for my part, etc., equidem, adv., emphasizing the subject.

for some time, iam diū. Cf. 202, 205.

for the purpose of, for the sake of, causā, following its genitive. Cf. 126.

for this reason, quā rē; quam ob rem; quā dē causā.

forbid, vetō, -āre, vetuī, vetitum. force (noun), vīs, (vīs), $f$; ; threats of force, vis et minae.

force (verb), cōgō, -ere, coēgī, coāctum. Cf. 329,332 .

forced march, māgnum iter, māgnī itineris, $n$.

forces, troops, cōpiae, -ārum, $f . p l$. ford, vadum, $-\overline{1}, n$.

foreign, exterus, -a, -um.

foreigner, aliēnus, $-\overline{1}, m$.

foresight, prūdentia, -ae, f.; cōnsilium, $-\overline{1}, n$.

forest, silva, -ae, $f$. forget, . oblīvīscor, oblīvīscī, oblitus sum. Cf. 116, 1. forgetful, oblītus, -a, -um. Cf. 113-114.

form a conspiracy, coniūrātiōnem faciō, -ere, fēcī, factum.

former, pristinus, -a, -um; vetus, veteris; superior, -ius; prior, prius.

former (the) ... the latter, ille ... hìc. Cf. 35 .

formerly, quondam.

fortieth, quadrāgēsimus, -a, -um. fortification, mūnītiō, -ōnis, $f$. fortify, mūniō, -īre, -īvī, -ītum. fortunate, fortūnātus, -a, -um; fēlīx, -īcis.

fortune, fortūna, -ae, $f$.; good fortune, success, fēlīcitās, -tātis, $f$.; fortune, property, rēs, rērum, $f$. $p l$;; fortūnae, -ārum, f. $p l$.

fortune (have the good), contingit, -re, -tigit. With dat. of person and a complementary infinitive.

forty, quadrāgintā, indecl. numeral.

forum, forum, $-\overline{1}, n$.

forward (go), prōgredior, -gredī, -gressus sum; prōcēdō, -ere, -cessī, -cessum.

foss, fossa, -ae, $f$.

found, condō, -ere, condidī, conditum.

founding of the city, urbs condita, urbis conditae, $f$. Cf. 368. four, quattuor, indecl. numeral. four hundredth, quadringentēsimus, -a, -um.

fourteenth, quārtus decimus. 
fourth, quārtus, -a, -um.

free, lïber, libera, lỉberum; vacuus, -a, -um. Cf. 149.

free $(v e r b)$, līberō, -āre, -āvì, -ātum.

Cf. 149.

freely, liberē.

friend, amīcus, -ī, m.; intimate

friend, familiāris, -is, $m$.

friendly, amīcus, -a, -um. Cf. 92. friendship, amīcitia, -ae, $f$.

fright (take), pertimēscō, -ere, -timuī, -.

frighten, terreō, -ēre, -uī, -itum.

frighten (thoroughly), perterreō, -ēre, -uī, -itum.

from, $\overline{\mathrm{a}}, \mathrm{ab}$; $\overline{\mathrm{e}}, \mathrm{ex}$; dē; abl. case. Cf. 146-149.

from, with verbs of hindering, etc. Cf. 269-271.

from all sides, undique; ab omnibus partibus.

from the vicinity of, $\bar{a}, a b$. Cf. 198 . from which, unde, $a d v$.

front, frōns, frontis, $f$; in front, $\bar{a}$ fronte.

fugitive, fugiēns, -entis, $m$.

full, plēnus, -a, -um; refertus, -a, -um. Cf. 113-115.

furnish, praebeō, -ēre, -uī, -itum. further, amplius, $a d v . ;$ longius, $a d v$. ; of time, diūtius, $a d v$.

furthermore, autem. Cf. 412 . praetereā.

\section{G}

Gabinian law, lēx Gabīnia, lēgis Gabīniae, $f$.

Gabinius, Gabīnius, $-\overline{1}, m$.

gain (noun), quaestus, -ūs, $m$.

gain (verb), adsequor, -sequī, -se-

cūtus sum; cōnsequor, -sequī, -secūtus sum; pariō, -ere, peperī, partum.

gain a desire or a request, impetrō, -āre, -āvī, -ātum.

gain possession, potior, -īrī, -ītus sum; occupō, -äre, -āvī, -ātum.

Gaius, Gāius, $-\overline{1}, m$.

Galba, Galba, -ae, $m$.

galley (war), nävis longa, nāvis longae, $f$.

Gallic, Gallicus, -a, -um.

garrison, praesidium, $-\overline{1}, n$.

gate, porta, -ae, $f$.

gather, bring together, cōgō, -ere, coēgī, coāctum; comparō, -āre, -āvī, -ātum; colligō, -ere, -lēgī, -lēctum.

gather, come together, conveniō, -ĩre, -vēnī, -ventum.

Gaul, the country, Gallia, -ae, $f$.

Gaul, an inhabitant of Gaul, Gallus, $-\overline{1}, m$.

Gaul (of or in), Gauls (of or with) Gallicus, -a, -um.

general, imperätor, -ōris, $m$.

Geneva, Genāva, -ae, $f$.; Lake Geneva, lacus Lemannus, lacūs Lemannī, $m$.

genius, ingenium, $-\overline{\mathbf{1}}, n$.

German (noun), Germānus, -ī, $n$. German (adj.), Germānicus, -a, -um.

Germany, Germānia, -ae, $f$.

get a firm foothold, fïrmiter insistō, -ere, -stitī, -

get back, regain, recuperō, -āre, -āvì, -ātum; recipiō, -ere, -cēpī, -ceptum.

get control, get possession, potior, -īrī, -ìtus sum. Cf. 165-166.

give, dō, dare, dedī, datum; give 
evidence, indicium ēdō, -ere, -didī, -ditum.

\{ ive over, give up, trādō, -ere, -didī, -ditum.

\, ive warning, moneō, -ēre, -uī, -itum.

'slabrio, Glabriō, -ōnis, $m$.

ilad, laetus, -a, -um.

: lad (be), laetor, -ārī, -ātus sum;

gaudeō, -ēre, gāvīsus sum.

rladiator, gladiātor, -ōris, $m$. sladly, libenter; laetē; laetus,

-a, -um, adj.

glory, glōria, -ae, $f$; fāma, -ae,

$f . ;$ laus, laudis, $f$.

Gnaeus, Gnaeus, $-\overline{1}, m$.

go, eō, îre, iī (īvī), itum.

go away, abeō, -īre, -iī, -itum.

go back, redeō, -īre, -īi, -itum;

revertor, revertī, revertī or reversus sum.

go forth, exeō, -īre, -ī̄, -itum; ègredior, ēgredī, ègressus sum; proficīscor, -ī, profectus sum; excēdō, -ere, -cessī, -cessum; discēdō, -ere, -cessī, -cessum. go forward, prōgredior, -gredī, -gressus sum; prōcēdō, -ere, -cessī, -cessum.

go on, passive of agō, -ere, ēgī, āctum; passive of gerō, -ere, gessī, gestum.

go out. Cf. go forth.

go to, adeō, -îre, -iī, -itum.

go to meet, obviam eō; obvius (-a, -um) eō; mē obvium (-am) ferō; occurrō, -ere, -currī, -cursum. With dat. case.

god, deus, deī, $m$.

going to, expressed by the active periphrastic conjugation. gold, aurum, -ī, $n$.

gold (of), aureus, -a, -um.

good, bonus, -a, -um.

good fortune, fēlīcitās, -tātis, $f$.; fortūna, -ae, $f$.

good luck, fēlīcitās, -tātis, $f$. good will, voluntās, -tātis, $f$; grātia, -ae, $f$.

government, rēs pūblica, rēi pūblicae, $f$.

governor, prōcōnsul, -is, $m$.

Gracchus, Gracchus, -ĩ, $m$.

grade, gradus, -ūs, $m$.

grain, frūmentum, $-\overline{1}, n$.

grain supply, rēs frūmentāria, reī frūmentāriae, $f$.

grant, dō, dare, dedī, datum; concēdō, -ere, -cessĩ, -cessum; permittō, -ere, -mīsī, -missum. granted that, ut; negative, nē. Cf. 321.

grateful (feel), grātiam habeō, -ēre, -uī, -itum.

gratitude, grātia, -ae, $f$.

Gratius, Grātius, $-\overline{1}, m$.

great, māgnus, -a, -um; ingēns, -entis; very great, summus, -a, -um; māximus, -a, -um.

great (as), tantus, -a, -um; as great as, tantus ... quantus. great (how), quantus, -a, -um. great numbers (in), frequēns, -entis.

great (so), tantus, -a, -um.

greater (the) . . the greater, quantō māior . . . tantō māior; quō māior . . . hōe (eō) māior. Cf. 160-162.

greatest importance (be of), māximī interest. Cf. 122-124. greatly, vehementer; māgnopere. 
greatness, māgnitūdō, -dinis, $f$.

Greece, Graecia, -ae, $f$. greed, avāritia, -ae, $f$.; cupiditās, -tātis, $f$.

greedy, avidus, -a, -um.

Greek, Graecus, -a, -um.

grieve, doleō, -ēre, -uī, -

grieve at, doleō, -ēre, -uī, -

60.

ground, humus, -ī, m.; on the ground, humi. Cf. 196.

guard (noun), praesidium, -ī, n.;

guard, sentinel, cūstōs, -ōdis,

$m$.; watch, vigilia, -ae, $f$.

guard (verb), tueor, -ērī, tūtus

sum; dēfendō, -ere, -fendī, -fēnsum.

guardianship, praesidium, $-\overline{1}, n$. guidance of (under the). Use the

ablative absolute. Cf. 370 .

guide, dux, ducis, $m$.

$\mathrm{H}$

habit, mōs, mōris, m.; cōnsuētūdō, -dinis, $f$.

habit of (be in the), soleō, -ēre, solitus sum; cōnsuēvì. Cf. 209. Imperfect tense. Cf. 203. halt, cōnsistō, -ere, -stitī, - . hampered, impedîtus, -a, -um. hand, manus, -ūs, $f$.

hand (be at), adsum, -esse, -fuī, -futūrus.

hand (on the other), autem. Cf. $412,1$.

hand down, hand over, trādō, -ere, -didī, -ditum.

hang over, impendeō, -ēre,,-- . happen, it happens, accidit, -ere, accidit, especially of bad fortune; contingit, -ere, -tigit, especially of good fortune; fit, fierì, factum est. Cf. 264 .

happen, go on, passive of gerō, -ere, gessī, gestum; passive of agō, -ere, ēgī, āctum.

harass, lacessō, -ere, -īvī, -ītum; vexō, -āre, -āvī, -ātum.

harbor, portus, -ūs, $m$.

hardship, labor, -ōris, $m$.

harm (noun), iniūria, -ae, $f$.; dētrìmentum, $-\overline{\mathbf{l}}, n . ;$ do harm. Cf. harm, verb.

harm (verb), noceō, -ēre, -ūi, -itum. Cf. 79-82.

harmony, concordia, -ae, $f$.

hasten, properō, -āre, -āvī, -ātum; contendō, -ere, -tendī, -tentum; mātūrō, -āre, -āvī, -ātum.

hate, ōdī, ōsūrus. Cf. 209-210. be hated, in odiō sum. With dat. case.

hatred, invidia, -ae, $f_{\text {.; }}$ odium, $-\overline{1}, n$.

haughty, superbus, -a, -um.

have, habeō, -ēre, -uī, -itum.

have influence, possum, posse,

potuī, -; valeō, -ēre, -uī, -itūrus. Cf. 66.

have to do with, pertineō, -ēre, -uī, -tentum. With ad and acc. case.

he, is; hic; ille. Usually not expressed as subject of a finite verb. Cf. 16, 20, 33.

head, caput, capitis, $n$.

hear, hear of, audiō, -īre, -īvī, -itum.

height, altitūdō, -dinis, $f$.

heights, superiōra loca, superiōrum locōrum, $n . p l$.

help (noun), auxilium, -ī, .n.; 
opera, -ae, $f_{.}$; by the help of, /hold an opinion, sentiō, -ĩre, sēnsī, per, prep. with acc.

ıelp (verb), iuvō; -āre, -iūvī, (iūtum); adiuvō, -āre, -iūvī, (-iūtum); adsum, -esse, -fuī, -futūrus.

felvetian (adj.), Helvēticus, -a, -um.

Helvetian (noun), Helvētius, $-\overline{1}, m$. Heraclea, Hēraclīa, -ae, $f$. Heraclean, a citizen of Heraclea, Hēraclīensis, -is, $m$.

here, hīc, $a d v$.

hereafter, posthāc, adv.

heretofore, anteā; adhūc.

hesitate, dubitō, -āre, -āvī, -ātum.

With infinitive. Cf. 328-329, 273.

hiding places, latebrae, -ārum, $f$. $p l$.

high, altus, -a, -um; of high birth, nōbilis, -e.

highest, greatest, summus, -a, -um. highly, māgnī. Cf. 122.

hill, collis, -is, $m$.

himself, - , sui; reflexive; ipse, ipsīus, intensive. Cf. 19-25, 38.

hinder, impediō, -īre, -īvī, -ītum; prohibeō, -ère, -uī, -itum. Cf. 269-271.

hindrance, impedīmentum, $-\overline{\mathbf{i}}, n$. his, suus, -a, -um, reflexive; èius.

Cf. 20-25.

hither ( $a d j$.$) , citerior, -ius.$

hitherto, adhūc.

hold, teneō, -ēre, -uī, tentum; habeō, -ēre, -uī, -itum; obtineō, -ēre, -ūī, -tentum.

hold a trial, iūdicium agō, -ere, $\bar{e} \bar{i} \bar{i}$ āctum. sēnsum.

hold back, retineō, -ēre, -uī, -tentum; contineō, -ēre, -uī, -tentum.

hold in check, coerceō, -ēre, -uī, -itum. Cf. hold back.

hold out, sustineō, -ēre, -uī, -tentum.

hold out against, resistō, -ere, -stitī, -; sustineō, -ēre, -uīi. -tentum.

home, domus, -ūs, $f$. Cf. 194 . 197. tēctum, -ī, n.; domicilium, $-\overline{1}, n$.

Homer, Homērus, $-\overline{1}, m$.

honesty, fidēs, -ē̄, $f$.

honor (noun), integrity, fidēs, -eī, $f$.; honor, respect, honor, -ōris, $m$.

honor (verb), honōrō, -āre, -āvī, -ātum.

honorable, honestus, -a, -um.

hope (noun), spēs, speī, $f$.; have hope, in spem veniō, -īre, vēnī, ventum. Cf. hope, verb. hope (verb), spērō, -āre, -āvī, -ātum. horse, equus, $-\overline{1}, m$.

horseback (on), in equō or in equīs.

horpeman, eques, equitis, $m$.

Hortensius, Hortēnsius, $-\overline{1}, m$.

hostage, obses, obsidis, $m$.

hostile, inimīcus, -a, -um; infēstus, -a, -um.

hour, hōra, -ae, $f$.

house, domus, -ūs, $f$. Cf. 194197. tēctum, -ī, n.; aedēs, -ium, f. pl.; at the house of, apud, prep. with acc. Cf. French chez. 
how, quō modō; quā ratiōne; if only, dum modo; tantum modo. quem. ad modum; with adj. or adv., quam.

how great, how large, quantus, -a, -um.

how many, quot, indecl. noun or adj.; quam multī, -ae, -a.

how many times, quotiēns, $a d v$. how much, quantus, -a, -um.

As a noun, quantum, $-\overline{\mathrm{I}}, n$.

how often, quotiēns, $a d v$.

however, tamen; autem. 412.

however much, quamvis, adv. Cf. 319 .

huge, ingēns, -entis.

hundred, centum, indecl. numeral. hundred and sixth, centēsimus sextus.

hundredth, centēsimus, -a, -um. hunger, famēs, -is, $f$.

hurl, iaciō, -ere, iēcī, iactum; coniciō,-ere, coniēcī, coniectum; hurl at any one, in aliquem iaciō.

hurl away, abiciō, -ere, -iēcĩ, -iectum.

hurl back, reiciō, -ere, reiēcī, reiectum.

hurry, accelerō, -āre, -āvī, -ātum.

\section{I}

I, ego, meĩ. Usually not expressed. Cf. 16.

I would that, utinam; velim. Cf. 226-231.

Iccius, Iccius, $-\mathbf{1}, m$.

Ides, İdūs, -uum, $f . p l$. Cf. 177180.

if, sĩ; but if, sĩn. Cf. 299.

if not, nisi; sī nōn. Cf. 299.

ignorant, ignārus, -a, -um; imperītus, -a, -um (rērum). Cf. 113-114.

ignorant (be), īgnōrō, -āre, -āvī, -ātum; nesciō, -īre, -ĩvī, -ītum. ill disposed, inimīcō animō. Cf. 140-141.

Illyricum, Īllyricum, -ī, $n$. image, imāgō, -ginis, $f$. ; simulācrum, $-\overline{1}, n$ :

immediately, statim.

immortal, immortālis, -e.

implore, implōrō, -āre, -āvī, -ātum. importance (be of), interest, -esse, -fuit. Cf. 124 . be of little (great, so great) importance, parvī (māgnī, tantī) est. Cf. 122.

important (so), tantus, -a, -um. imprison, in cūstōdiam dō, dare, dedī, datum.

imprisonment, cūstōdia, -ae, $f$.; (chains), vincula, -ōrum, $n . p l$. in, in, prep. with abl. and acc. cases.

in accordance with, ex or dē, with the abl. case. Cf. 138-139.

in as much as, quod; cum; quoniam; quia. Cf. 294, 297.

in behalf of, prō, prep. with abl. case.

in defense of, prō, prep. with abl. case.

in order to, ut. Cf. 253-254.

in return for, prō, prep. with abl. case.

in that, quod; relative clause. Cf. 293.

in vain, frūștrā, nēquĩquam. 
activity, inertia, -ae, $f$. cite, sollicitō, -āre, -āvī, -ātum; excitō, -āre, -āvī, -ātum.

c. consistent (be), abhorreō, -ēre, -uī, - With ab and abl. case. i: ıcrease, make larger, augeō, -ēre, auxī, auctum. Transitive verb. i ıcrease, grow larger, crēscō, -ere, crēvī, crētum. Intransitive verb. i ıdeed, quidem; vērō; sānē; certē; then indeed, tum vērō. iafantry, peditātus, -ūs, m.; peditēs, -um, m. pl. inflict, īnferō, -ferre, -tulī, inlātum (illātum).

inflict punishment on some one, supplicium dē aliquō sūmō, -ere, sūmpsī, sūmptum; in aliquem animadvertō, -ere, -vertī, -versum; aliquem suppliciō afficiō, -ere, -fēcī, -fectum. influence (noun), political influence, auctōritās, -tātis, f.; personal influence, grātia, -ae, $f$. influence (verb), addūcō, -ere, -dūxī, -ductum; indūcō, -ere, -dūxī, -ductum; moveō, -ēre, mōvī, mōtum; impellō, -ere, -pulī, -pulsum.

influence (have), be of influence, possum, posse, potuī, - ; valeō, -ēre, -ūi, valitūrus. Cf. 66 .

inform, certiōrem faciō, -ere, fēcī, factum. Certior agrees with the object.

informed (be), certior fīō, fierī, factus sum. Certior agrees with the subject.

inhabit, incolō, -ere, -coluī, injure, nocēo, -ēre, -uī, -itum. Cf. $79-80,82$. injury, iniūria, -ae, $f$.

inland, interior, -ius.

innocent, innocēns, -entis.

inquire, quaerō, -ere, quaesīvī, quaesītum; rogō, -āre, -āvī, -ātum. Cf. 72 .

inquiry (make), quaerō, -ere, quaesīvī, quaesītum. Cf. 72, 65. inside (prep.), intrā, prep. with acc. case; $a d v$., intus.

inspire dread or fear in any one, alicuī metum iniciō, -ere, -iēcī, -iectum.

instruct, praecipiō, -ere, -cēpī, -ceptum; mandō, -āre, -āvī, -ātum.

instructions, mandāta, -ōrum, $n$. $p l$.

integrity, innocentia, -ae, $f$.; fidēs, fidēi, $f$.

intend, expressed by the active periphrastic conjugation. Cf. 252. in animō habeō, -ère, -uī, -itum.

intent, intention, animus, $-\overline{1}, m$. ; cōnsilium, -ī, m.; mēns, mentis, $f$.; sententia, -ae, $f$.

interchange, inter nōs damus, etc. Cf. 26.

interest (be to the), interest, -esse, -fuit; rēfert, -ferre, -tulit. Cf. 124.

interests, rēs, rērum, $f \cdot p l$.

interests of any one (look out for the), alicuī cōnsulō, -ere, -uĩ, cōnsultum. Cf. 79-80.

interval, intervāllum, -ī, $n$.; spatium, $-\overline{1}, n$.

into, in, prep. with acc. case.

invest, collocō, -āre, -āvī, -ātum. invite, invītō, -āre, -āvī, -ātum; 
send for, arcessō, -ere, -īvī, -ēre, -uī, -itum; interclūdō, -îtum.

island, insula, -ae, $f$.

it, is, ea, id. Cf. 36 .

it may be that, licet. Cf. 320 .

Italian, Ittalicus, -a, -um.

Italy, İtalia, -ae, $f$.

\section{J}

January, Iānuārius, -a, -um, adj. Cf. 176.

javelin, pìlum, $-\overline{\mathbf{1}}, n . ;$ tēlum, $-\overline{\mathbf{l}}, n$. join, coniungō, -ere, -iūnxī, -iūnc-

tum. Transitive verb.

journey, iter, itineris, $n$.

joy, gaudium, $-\overline{\mathrm{i}}, n$.; laetitia, -ae, $f$. judge (noun), jūdex, iūdicis, $-m$. judge (verb), iūdicō, -āre, -āvī, -ātum.

judgment, iūdicium, $-\overline{\mathbf{l}}, n$.

Julius, Iūlius, $-\overline{1}, m$.

Jupiter, Iuppiter, Iovis, $m$.

juror, iūdex, iūdicis, $m$.

just, aequus, -a, -um; iūstus,

-a, -um.

just as, ita ut; sicut.

just as if, velutsī; tamquamsī; acsī; quasi. Cf. 313.

just now, paulō ante; modo. justice, iūstitia, -ae, $f_{\text {.; }}$ aequitās, -tātis, $f$.

justly, iūre.

K

Kalends, Kalendae, -ārum, $f$. pl. $\quad$ Cf. 177.

keep, retain, teneō, -ēre, -uī,

tentura; retineō, -ēre, -uĩ, -tentum; contineō, -ère, -uī, -tentum.

keep away, keep from, prohibeō,

keep busy, occupō, -āre, -āvī, -ātum.

keep in mind, memoriā teneō, -ēre, -uī, tentum.

keep watch, vigilō, -āre, -āvī, -ātum.

kill, interficiō, -ere, -fēcī, -fectum; occīdō, -ere, -cīdī, -cīsum.

kind, sort, genus, generis, $n$.; modus, $-\bar{i}, m$.; of this kind, èius modī. Cf. 102.

kind, kind-hearted, lēnis, -e; mītis, -e; misericors, -cordis.

kindness, an act of kindness, beneficium, $-\overline{\mathbf{1}}, \quad n$.; feeling of kindness, hūmānitā̀s, -tātis, $f$.; lēnitās, -tātis, $f$.

king, rēx, rēgis, m.; of a (the) king, with a (the) king, rēgius, -a, -um, adj.

kingdom, rēgnum, $-\overline{1}, n$.

kinsman, propinquus, -i, $\quad m$.; cōnsanguineus, $-\overline{\mathbf{1}}, m$.

knight, eques, equitis, ' $m$.

know, sciō, -īre, -īvī, -îtum; sentiō, -īre, sēnsī, sēnsum; cōgnōvī. Cf. 209-210; intellegõ, -ere, -lēxī, -lēctum.

know (not), nesciō, -īre, -īvī, -ìtum; ìgnōrō, -āre, -āvī, -ātum. knowledge, scientia, -ae, $f$. known, nōtus, -a, -um.

L

Labienus, Labiēnus, $-\mathbf{i}, m$.

labor, labor, -ōris, $m$.

lack (noun), inopia, -ae, $f$.

lack (verb), careō, -ēre, carūī, caritūrus. Cf. 153. 
aeca, Laeca, -ae, $m$. and, general term, terra, -ae, $f$; territory, fīnēs, -ium, $m$. $p l$., ager, agrī, m.; native land, patria, -ae, $f . ;$ on land and sea, terrā marīque. Cf. 189. anguage, lingua, -ae, $f$. arge, māgnus, -a, -um; ingēns, -entis.

large (how), quantus, -a, -um. last, proximus, -a, -um. last (at), tandem; dēmum; dēnique.

lasting, aeternus, -a, -um; sempiternus, -a, -um; perpetuus, -a, -um.

late in the day, multō diē; late at night, multā nocte; until late at night, ad multam noctem.

later, posteā; post.

Latin, Latīnus, -a, -um; in Latin, Latīnē, $a d v$.

Latium, Latium, $-\overline{1}, n$. latter (the), hīc, haec, hōc. Cf. 35 .

laugh at, rīdeō, -ēre, rīsī, rīsum. Cf. 60.

law, a law, lēx, lēgis, f.; law, justice, iūs, iūris, $n$.

lay bare, patefaciō, -ere, -fēcī, -factum.

lay down (arms), abiciō, -ere, -iēcī, -iectum.

lay open, patefaciō, -ere, -fēcī, -factum.

lay waste, vāstō, -āre, -āvī, -ātum; populor, -ārī, -ātus sum.

lead, dūcō, -ere, dūx̄i, ductum̀.

lead across, trādūcō, -ere, -dūxī, -ductum. Cf. 62-63. lead back, redūcō, -ere, -dūxī, -ductum.

lead forth, ēdūcō, -ere, -dūxī, -ductum.

lead in, intrōdūcō, -ere, -dūxī, -ductum.

lead on, addūcō, -ere, -dūxī, -ductum; indūcō, -ere, -dūxī, -ductum.

lead out, ēdūcō, -ere, -dūxī, -ductum.

leader, dux, ducis, $m$.

leadership, prīncipātus, -ūs, m.; under the leadership of some one, aliquō duce. Cf. 370, 515.

leading man, prominent man, prīnceps, prīncipis, $m$.

learn, cōgnōscō, -ere, cōgnōvī, cōgnitum; reperiō, -īre, repperī, repertum; dīscō, dīscere, didicī, -

learned, doctus, -a, -um.

learning, doctrīna, -ae, $f$.

least powerful (be), have the least power, minimum possum (valeō). Cf. 66 .

leave, leave behind, relinquō, -ere, -līquī, -līctum; leave, go away from, go out of, exē, -ire, -iī, -itum, with ex and the $a b l$.; discēdō, -ere, -cessī, -cessum, with ex and abl.; ēgredior, ēgredī, ēgressus sum, with ex and abl.; excēdō, -ere, -cessī, -cessum, with ex and the abl. leave out of consideration, omittō, -ere, -mīsī, -missum.

left, sinister, -tra, -trum; on the left wing, $\bar{a}$ sinistrō cornū. legally, iūre.

legion, legiō, -ōnis, $f$. 
length (at), tandem; dēmum; dēnique; postrēmō; ad extrēmum.

leniency, lēnitās, -tātis, $f_{\text {.; }}$ clēmentia, -ae, $f$.

lenient, lēnis, -e; clēmēns, -entis. Lentulus, Lentulus, $-\overline{\mathbf{1}}, m$.

Lepidus, Lepidus, $-\overline{1}, m$.

less (adj.), minor, minus; as a noun, minus, minōris, $n$. Cf. 105.

less ( $a d v$.$) , minus. Cf. 159$.

less (none the), nec minus.

let. Cf. permit or allow. In exhortations expressed by the hortatory subjunct.

let loose upon, immittō, -ere, -mīsì, -missum, with in and the acc. case.

letter, littera, -ae, $f$., a letter of the alphabet; litterae, -ārum, $f . p l$., a letter, a dispatch; epistula, -ae, $f$., a personal letter. on private matters.

lēx Pāpia, lēgis Pāpiae, $f$., a law passed in 65 B.c. providing that all men not possessing Roman citizenship should be expelled from Rome.

liberty, lībertās, -tātis, $f$. lieutenant, lēgātus, $-\bar{i}, m$. life, vìta, -ae, $f$.

light, lūx, lūcis, $f$.

light (bring to), inlūstrō (illūstrō), -āre, -āvī, -ātum; patefaciō, -ere, -fēcī,-factum; dēprehendō, -ere, -prehendī, -prehēnsum.

light armed, expeditus, -a, -um. like ( $a d j$.), similis, -e. Cf. 92, 96. like (verb), volō, velle, voluī, -;

I should like, velim. Cf. 234, b, 230 . likely to, expressed by the active periphrastic conjugation. Cf. 252.

likewise, item.

line of battle, aciēs, -ēī, $f$.

line of march, army on the march, āgmen, āgminis, $n$.

Liscus, Liscus, $-\overline{\mathbf{1}}, m$.

listen to, audiō, -îre, -īvī, -ītum.

literary pursuits, studium litterārum.

literature, litterae, -ārum, $f . p l$.

little (adj.), parvus, -a, -um.

little ( $a d v$.), paulō. Cf. 160-161. little importance (of), of little value, parvi. Cf. 122.

live, vīvō, -ere, vīxī, vīctum, live; dwell, habitō, -āre, -āvī, -ātum; live, inhabit, incolō, -ere, -uī, live on, vēscor, vēscī, - With abl. case. Cf. 165.

long, of space, $a d j$., longus, -a, -um.

long, of time ( $a d v$.$) , diū.$

long time (for a), for a long while, diū, $a d v$.

longer (no), nōn diūtius; nōn iam.

look, videō, -ēre, vīdī, vīsum.

look after, prōvideō, -ēre, -vīdī, -vīsum. With dat. case.

look at, aspiciō, -ere, -spexī, -spectum; look at each other, inter sē aspicere. Cf. 26.

look out for (the interests of some one), prōvideō, -ere, -vīdī, -vīsum; cōnsulō, -ere, -uĩ, consultum. Cf. 79-80.

lose, āmittō, -ere, -mīsī, -missum. loss, calamitās, -tātis, $f$.; dētrīmentum, $-\overline{1}, n$. 
lo e (noun), amor, -ōris, $m$.

1o e (verb), amō, -āre, -āvī, -ātum.

10 $v$, inferus, -a, -um; lowest, infimus, -a, -um or ìmus, -a, -um. lo 'alty, voluntās, -tātis, $f$.

L. cullus, Lucullus, $-\overline{\mathbf{i}}, m$.

lu sury, lūxuria, -ae, $f$.

\section{M}

nlad, āmēns, āmentis; dēmēns, dēmentis.

ruadness, āmentia, -ae, f.; dēmentia, -ae, $f$.

magistracy, magistrātus, -ūs, $m$. magistrate, magistrātus, -ūs, $m$. rake, faciō, -ere, fēcī, factum; efficiō, -ere, -fēcī, -fectum.

make a move, mē commoveō, -ēre, -mōvī, -mōtum.

make a promise, polliceor, -ērī, pollicitus sum.

make a reply, make answer, respondeō, -ēre, -spondī, -spōnsum.

make an attempt, cōnor, -ārī, -ātus sum.

make an attack on some one, in aliquem impetum faciō, -ere, fēcī, factum.

make an enemy, inimīcum suscipiō, -ere, -cēpī, -ceptum.

make an inquiry, quaerō, -ere, quaesīvī, quaesītum.

make war on some one, alicuī bellum inferō, -ferre, intulī, inlātum (illātum).

make way with, tollō, -ere, sustulī, sublātum.

man, the general term, homō, hominis, m.; with reference to a man of high qualities, vir, virī, m.; a man who, is quī. Cf. 36 .

manage, administrō, -āre, -āvī, -ātum; gerō, -ere, gessī, gestum. manhood (early), aetās inita, aetātis initae, $f$.

Manilian law, lēx Mānīlia, lēgis Mānìliae, $f$., a law designed to place Pompey in charge of the Third Mithridatic War.

Manius, Mānius, -ī, $m$.

Manlius, Mānlius, -ī, m.; of Manlius, Manlian, Mānliānus, -a, -um.

manner, ratiō, -ōnis, $f . ;$ modus, -ī, m.; ōrdō, ōrdinis, $m$.

many, multī, -ae, -a; complūrēs, complūra (-ia).

many (as), tot; as many as, tot ... quot.

many as possible (as), quam plūrimī, -ae, -a.

many (how), quot, indecl. noun and adj.

march (noun), iter, itineris, n.; on the march, in itinere; ex itinere.

march (verb), iter faciō, -ere, fēcī, factum.

march (forced), māgnum iter, māgnī itineris, $n$.

march forward, prōgredior, -gredī, -gressus sum; prōcēdō, -ere, -cessī, -cessum.

March, the month of March, Mārtius, -a, -um, adj. Cf. 176. Marcus, Mārcus, -ĩ, $m$. maritime, maritimus, -a, -um. mark out, select, cōnstituō, -ere, -stituī, -stitūtum.

Marseilles, Massilia, -ae, $f$. 
match, pār, paris. Cf. 92 . matter, affair, rēs, reī, $f$. may, expressed by the subjunctive. Cf. $227,253,254$.

may, it is permitted, licet, licēre, licuit. Cf. $325,3$.

meantime, meanwhile, interim; intereā.

meet, occurrō, -ere, -currī, -cursum; obviam eō, īre, ī̄ (īvī), itum. With dat.

meet (in conflict), congredior, -gredī, -gressus sum. With cum and the abl.

meeting, concilium, -ī, n.; conventus, -ūs, $m$.

memorial, monumentum, $-\overline{1}, m$. memory, memoria, -ae, $f$; within the memory of man, post hominum memoriam.

Menapii, Menapiī, -ōrum, m. pl. mention, commemorō, -āre, -āvī, -ātum.

merchant, mercātor, -ōris, $m$.

mere, ipse, -a, -um.

message, nūntius, $-\overline{\mathbf{1}}, m$.

messenger, nūntius, $-\bar{i}, m$.

Metellus, Metellus, $-\bar{i}, m$.

method of attack, oppūgnātiō, -ōnis, $f$.

Mettius, Mettius, -ī, $m$.

middle, midst, medius, $-\mathrm{a},-\mathrm{um}$, adj. Cf. 108.

midnight, media nox, mediae noctis, $f$.

might. Cf. may.

mild, mītis, -e; lēnis, -e.

mildness, lēnitās, -tātis.

mile, mīlle passūs, mïlle passuum,

m. $p l$.; miles, mìlia passuum, $n$. pl. Cf. 494, 3 . military, mīlitāris, -e; military affairs. (matters), rēs mīlitāris, rēi mīlitāris, $f_{\text {.; }}$ military tribune, tribūnus mīlitum.

mind, of mental qualities, mēns, mentis, $f$.; of emotional qualities, animus, $-\overline{1}, m$.

mindful, memor, memoris. Cf. 113-114.

mine, meus, -a, -um.

misdeed, iniūria, -ae, $f_{\text {.; }}$ maleficium, $-\overline{\mathbf{1}}, n$.

misfortune, calamitās, -tātis, $f$.

Mississippi, Mississippī, -ōrum, $m$. $p l$.

mistake (make a), be mistaken, errō, -āre, -āivi, -ātum.

Mithridates, Mithridātēs, -is, $m$.

Mithridatic, Mithridāticus, -a, -um. moderation, modus, -ì, m.; temperantia, -ae, $f$.

moment (of such), tantī. Cf. 122. money, pecūnia, -ae, $f$.

month, mēnsis, -is, $m$.

more (noun), plūs, plūris, n., with partitive gen. Cf. 105 .

more (adj.), plūrēs, plūra, $p l$. Not used as adj. in the sing. more (adv.), of degree, magis; of amount, plūs, adv.; amplius, $a d v$.

moreover, autem. Cf. 412. praetereā.

Morini, Morinī, -ōrum, m. pl.

morning (early in the), māne; this morning, hodiernō diē māne.

motion, recommendation, sententia, -ae, $f$.

mountain, mōns, montis, $m$.

mournful, trīstis, -e. 
aor ə, moveō, -ēre, mōvī, mōtum; " mmoveō, -ēre, -mōvī, -mōtum. aore (make a), mē commoveō, -i re, -mōvī, -mōtum.

aur h (adj.), multus, -a, -um.

au h (adv.), multum; māgnopere; in ultō.

aul h as (as or so), tantus... 'juantus.

aul :h (how), quantus, -a, -um.

ati 'h (so), tantus, -a, -um.

au titude, multitūdō, -dinis, $f$.

aulder (noun), caedēs, -is, $f$.

Commit murder. Cf. murder, verb.

aurder (verb), interficiō, -ere, -fēcī, -fectum; occīdōं, -ere, -cīdī, -cīsum; trucīdō, -āre, -āvī, -ātum; necō, -āre, -āvī, -ātum. Iurena, Mūrēna, -ae, $m$.

aust, necesse est. Cf. 325, 3. Expressed by the periphrastic conjugation. Cf. 383-389.

ay, meus, -a, -um.

ayself, ego, meì.

\section{$\mathrm{N}$}

lame (noun), nōmen, nōminis, $n$. i ame (verb), nōminō, -āre, -āvī, -ātum. Cf. 58, 67-69.

amed, by name, nōmine. Cf. 142-143.

arrow, angustus, -a, -um; narrow, restricted, exiguus, -a, -um.

ution, gēns, gentis, $f . ; \quad$ nātiō, -ōnis, $f$.

ative land, patria, -ae, $f$.

ature, nātūra, -ae, f.; character, genus, generis, $n$.

aval, nāvālis, -e.

avigate, nāvigō, -āre, -āvī, -ātum. near, prope, adv. and prep. with acc. case.

nearby, proximus, -a, -um, adj.

nearest, proximus, -a, -um; fīnitimus, -a, -um. Cf. 92, 94.

necessary (it is), necesse est. Cf. $325,3$.

necessity, ūtilitās, -tātis, $f$.; necessitās, -tātis, $f$.

need (noun), opus, indecl. noun. Cf. 155-156.

need (I), mihi opus est, with abl. of the thing needed. Cf. 155- . 156.

needless (it is), nōn necesse est. Cf. $325,3$.

neglect, neglegō, -ere, -lēxī, -lēctum.

neighbor, fīnitimus, $-\overline{\mathbf{1}}, m$.

neighboring, fīnitimus, -a, -um; vicinus, -a, -um.

neither (adj. and pron.), neuter, -tra, -trum.

neither (conj.), neque (nec); neither ... nor, neque (nec) ... neque (nec).

Nervii, Nerviī, -ōrum, m. $p l$.

never, numquam.

nevertheless, tamen.

new, novus, -a, -um.

next, next to, proximus, -a, -um. Cf. 92,94 . on the next day, posterō diē; proximō diē; postrīdiē ēius diēī.

night, nox, noctis, $f_{\text {.; }}$ by night, noctū; midnight, media nox, mediae noctis, $f$.

nine, novem, indecl. numeral. ninth, nonus, -a, -um.

no (adv.), nōn; negative answer. Cf. 225. 
no (adj.), nūllus, -a, -um. nihil, with partitive genitive. Cf. 105. no longer, nōn iam; nōn diūtius. no one, nēmō, - $m$. and $f$.; nē quis. Cf. 265. noble, nōbilis, -e. noble conduct, virtūs, -tūtis, $f$. none, nūllus, -a, -um.

none the less, nihilo minus; nec minus.

Nones, Nōnae, -ārum, f. pl. Cf. 177.

nor, neque (nec). Cf. 394, 399. not, nōn, nē; after verbs of fearing, ut. Cf. 266, 267.

not at all, nihil, adv.

not even, nē ... quidem.

$412,2$.

not know, be ignorant, nesciō, -īre, -ĩvī, -ītum; ìgnōrō, -āre, -āvī, -ātum.

not only . . but also, nōn modo (sōlum) . . . sed (vērum) etiam; cum . . . tum. Cf. 399.

not worthy, indignnus, -a, -um.

Cf. 145, 274-275, 569.

not yet, nōndum.

nothing, nihil, indecl. noun.

notice, videō, -ēre, vīdī, vīsum; animadvertō, -ere, -vertī, -versum.

November, November, -bris, -bre. Cf. 176.

Noviodunum, Noviodūnum, -ī, $n$. now, nunc; iam; now for a long time, iam diū; iam dūdum; iam prīdem. Cf. 202, 205.

number, numerus, -ī, m.; a great number, multitūdō, -dinis, $f$.; in great numbers, frequēns, -entis, adj. numerous, multī, -ae, -a; crēber, -bra, -brum.

\section{O}

oath, iūs iūrandum, iūris iūrandī, n.; oath-bound pledge, fidēs et iūs iūrandum.

obey, pāreō, -ēre, -uī, - Cf. 79-82.

object, rēs, reī, $f$.

observe, cernō, -ere, crēvī, crētum; videō, -ēre, vīdī, vīsum.

obtain, cōnsequor, -sequī, -secūtus sum.

obtain a request, impetrō, -āre, -āvì, -ātum.

occasion, circumstance, locus, $-\overline{1}$, $m$.; on many occasions, saepe, $a d v$.

o'clock, hōra. Cf. 175.

October, Octōber, -bris, -bre, adj. Cf. 176.

of, usually expressed by the genitive case; of, concerning, dē, prep. with abl.

offer, offerō, -ferre, obtulī, oblātum; prōpōnō, -ere, -posuī, -positum.

office, magistrātus, -ūs, $m$. often, saepe.

old, of olden time, of old, vetus, veteris.

omen, ōmen, ōminis, $n$.

on, in, prep. with acc. and abl. cases. Cf. also 167 . on, concerning, dē, prep. with abl. case.

on account of, propter, prep. with acc.; ob, prep. with acc.; abl. case. Cf. 135-136. 
on all sides, undique.

on both sides, ab utrōque latere; b utrāque parte.

on land and sea, terrā marīque. (f. 189.

on the right (left) wing, $\bar{a}$ dextrō (sinistrō) cornū.

on the other hand, autem, adv. (f). $412,1$.

once (at), statim.

ons:, ūnus, -a, -um; one ... another, alius ... alius; the one ... the other, alter ... ilter. Cf. 56.

me (no), nēmō,-, $m$. and $f$.

one at a time, one by one, singuli, -ae, -a, adj.

oilly (adj.), sōlus, -a, -um; ūnus, -a, -um.

only (adv.), tantum; not only . . . but also, nōn modo (sōlum) ... sed (vērum) etiam; cum .. . tum. Cf. 280, note.

pen ( $a d j$.$) , apertus, -a, -um.$

pen (verb), aperiō, -īre, aperuī, apertum.

pen up, patefaciō, -ere, -fēcī, -factum.

pinion, sententia, -ae, $f$; opīniō, -ōnis, $f_{\text {.; }}$ animus, -ī, $m$.

pinion (entertain or hold an), sentiō, -īre, sēnsī, sēnsum.

pportunity, occāsiō, -ōnis, f.; facultās, -tātis, $f_{\text {; }}$; opportūnitās, -tātis, $f$.

ppose, oppōnō, -ere, -posuī, -positum; obstō, -āre, -stitī, -; resistō, -ere, -stitī, -

'pposite, contrārius, -a, -um; adversus, -a, -um. Cf. 92.

sppressive, gravis, -e. or, aut; vel; sīve; an. Cf. 398399, 221.

or not, annōn; necne. Cf. 222. oration, ōrātiō, -ōnis, $f_{\text {; ; }}$ deliver an oration, ōrātiōnem habeō, -ēre, -uī, -itum.

orator, ōrātor, -ōris, $m$.

order (noun), arrangement, ōrdō, ōrdinis, $m$.

order (noun), command, iūssus, -ūs, m.; iūssum, -ī, n.; imperātum, -ī, n.; mandātum, $-\bar{i}, n$.

order (verb), iubeō, -ēre, iūssī, iūssum; imperō, -āre, -āvī, -ātum. Cf. 79-82, 262-263. mandō, -āre, -āvī, -ātum.

order to (in), ut. Cf. 253-254. Orgetorix, Orgetorix, -igis, $m$. other, alius, -a, -ud; other of two, alter, altera, alterum. Cf. 56. other (the), of two, alter, altera, alterum; of more than two, reliquus, -a, -um; the other, the others, cēterī, -ae, -a; reliquī, -ae, -a.

other's, of another, of others, aliēnus, -a, -um, adj.

ought, dēbeō, -ēre, -uī, -itum; oportet, oportēre, oportuit. Cf. 325, 2. Expressed by the passive periphrastic conjugation. Cf. 383.

our, noster, nostra, nostrum. out of, ex, prep. with abl. case. outcome is (the), ēvenit, ēvenīre, ēvēnit. Cf. 264.

outside, extrā, prep. with acc. case. over, super, prep. with acc. and abl. cases; in, prep. with acc. and abl. cases. 
overcome, superō, -āre, -āvī, -ātum; vincō, -ere, vīcī, victum. overlook, neglegō, -ere, -lēxī, -lēetum; praemittō, -ere, -mīsī, -missum.

overtake, cōnsequor, -sequĩ, -se-

cūtus sum; cōnsector, -ārī, -ātus sum.

overthrow, èvertō, -ere, -vertī, -versum.

overturn, dēiciō, -ere, -iēcī, -iectum.

overwhelm, comprimō, -ere, -pressī, -pressum.

owe, dēbeō, -ēre, -uī, -itum.

own. Cf. my, your, his, her, etc.

$\mathrm{P}$

pace, passus, -ūs, $m$.

pacify, pācō, -āre, -āvī, -ātum.

Paphlagonia, Paphlagonia, -ae; $f$.

pardon, ìgnōscō, -ere, īgnōvi, īgnōtum. Cf. 79-80.

part, pars, partis, $f$.

participant, socius, -ī, m.; particeps, participis, $m$.

pass, of time, exigō, -ere, -ēgī, -āctum.

pass a law, lēgem ferō, ferre, tulī, lātum; lēgem cōnstituō, -ere, -stituī, -stitūtum.

pass a decree, dēcernō, -ere, -crēvī, -crētum.

passage, iter, itineris, $n$. past years (these), hī annī. past (in the), anteā; ante id tempus.

patience, patientia, -ae, $f$. patriotic, amāns patriae; amāns reī pūblicae. patriotism, amor patriae; amo reĩ pūblicae.

pay, pendō, -ere, pependī, pēn sum; pay the penalty, poenā: pendō, poenās dō; poenās per solvō, -ere, -solvī, -solūtum.

peace, pāx, pācis, $f$.

Pedius, Pedius, $-\overline{\mathbf{1}}, \mathrm{m}$.

people (a), gēns, gentis, $f$; nātiō -ōnis, $\quad f$.; populus, -ī, $m$. the Roman people, populus Rōmānus; people, men hominēs, -um, m. pl.; the people, the common people plēbs, plēbis, $f . ;$ multitūdō -dinis, $f$.

people (of the), populäris, -e. perform, fungor, fungī, fūnctus sum. Cf. 165.

perhaps, forte, fortasse.

peril, perīculum, -ī, $n$.

perish, pereō, -ïre, -iī, -itum.

permit, patior, patī, passus sum

Cf. 329. sinō, -ere, sīvī, situm

Cf. 329. permittō, -ere, -mīsī -missum. Cf. 262.

persuade, persuādeō, -ēre, -suāsī -suāsum. Cf. 79-82, 262.

phalanx, phalanx, phalangis, $f$.

pirate, praedō, -ōnis, $m$.

pitch camp, castra pōnō, -ere -posuī, -positum; castra locō, -āre, -āvī, -ātum.

pity, miseret, miserēre, miseruit. Cf. 118-119. misereor, ērī, -itus sum. Cf. 120.

Pius, Pius, -ī, $m$.

placate, plācō, -āre, -āvī, -ātum. place (noun), locus, $-\overline{1}, m$. (n. in $p l$.); pars, partis, $f$.

place (verb), pōnō, -ere, posūi, 
ssitum; locō, -āre, -āvī, -ātum; llocō, -āre, -āvī, -ātum; place .t intervals), dispōnō, -ere, ısuī, -positum.

plate of (in), prō, prep. with abl. c tse.

dis (in the second), deinde, $a d v$. la :e in charge, place in command, | raeficiō, -ere, -fēcī, -fectum. ('f. 83-84.

la zue, pestis, -is, $f$.

olain, campus, -ī, m.; plānitiēs, - èì, $f$.

lan (noun), cōnsilium, -ī, n.; ratiō, -ōnis, $f_{\text {.; }}$ adopt a plan, (ōnsilium capiō; cōnsilium neō.

Jlan (verb), cōgitō, -āre, -āvī, -ātum; mōlior, -īrī, -ītus sum. lead a case, causam dīcō, -ere, dīxī, dictum.

leasant, iūcundus, -a, -um; grātus, -a, -um. Cf. 113-114.

lease, placeō, -ēre, -uī, -itum. Cf. 79-82. dēlectō, -āre, -āvī, -ātum. Cf. 81.

leasing, grātus, -a, -um; iūcundus, -a, -um. Cf. 92.

leasure, voluptās, -tātis, f.; it is a very great pleasure, iūcundissimum est.

ledge (noun), fidēs, fidē.

ledge one's word, fidem interpōnō, -ere, -posuī, -positum.

lot (noun), īnsidiae, -ārum, $f . p l$.; cōnsilium, $-\overline{\mathrm{i}}, n$.

lot (verb), cōgitō, -āre, -āvī, -ātum; mōlior, -īrī, -ītus sum. lunder (noun), praeda, -ae, $f$. lunder (verb), dīripiō, -ere, -ripuī, -reptum. poet, poēta, -ae, $m$. point (at this), hice, $a d v$. Pompey, Pompēius, -ī, $m$. Pomptinus, Pomptinus, $-\overline{1}, m$. Pontus, Pontus, -ī, $m$. poor, miser, misera, miserum. popularity, grātia, -ae, $f$. popular, of the people, populāris, -e. populous, celeber, -bris, -bre. portent, mōnstrum, -ī, $n$. position, locus, $-\bar{i}, m$.

possess, of concrete objects, habeō, -ēre, -uī, -itum; teneō, -ēre, -uī, tentum; of abstract qualities, in aliquō est aliqua rēs. Cf. also Dative of the Possessor, 85-86.

possession, possessiō, -ōnis, $f$. possession of (be in), possideō, -ēre, -sēdī, -sessum. Cf. possess. possession of (gain or get), potior, -īrī, -ītus sum. Cf. 165-166.

possible (as ... as), quam, with the superlative; as soon as possible, quam prīmum. postpone, cōnferō, -ferre, contulī, conlātum (collātum).

power, military power. imperium, -ī, n.; civil authority, potestās, -tātis, $f$.; royal power, rēgnum, $-\overline{\mathbf{1}}, n$.; ability in general, facultās, -tātis, $f$.

power (have), possum, posse, potuī, -; valeō, -ēre, -uī, -itūrus. Cf. 66 .

powerful, potēns, -entis.

powerful (be), possum, posse, potuī, -; valeō, -ēre, -uī, -itūrus. Cf. 66. 
practice, exercitātiō, -ōnis, $f$. praetor, praetor, -ōris, $m$. praetorship, praetūra, -ae, $f$. praise (noun), laus, laudis, $f$. praise (verb), laudō, -āre, -āvī, -ātum.

precedent, exemplum, $-\overline{1}, n$. preceding day (on the), prīdiē, $a d v$.

prefer, mālō, mālle, māluī, prepare, parō, -āre, -āvī, -ātum; comparō, -āre, -āvī, -ātum.

presence of (in the), use the abl. abs. of praesēns. Cf. 370 .

present (verb), dōnō, -āre, -āvī, -ātum. Cf. 78, a. dō, dare, dedī, datum.

present (be), adsum, -esse, -fuī, -futūrus.

preserve, servō, -āre, -āvī, -ātum; cōnservō, -āre, -āvī, -ātum.

press hard, premō, -ere, pressī,

pressum; urgeō, -ēre, ursī, press on, instō, -āre, -stitī, -stātum. prestige, auctōritās, -tātis, $f$. prevail, prove stronger, plūs valeō, -ēre, -ū̄, -itūrus; superō, -āre, -āvī, -ātum.

prevail on some one, ab aliquō impetrō, -āre, -āvī, -ātum. prevent, prohibeō, -ēre, -uī, -itum.

Cf. 271. impediō, -īre, -īvī, -itum. Cf. 269-270. dēterreō, -ēre, -uī, -itum. Cf. 269270.

principle, lēx, lēgis, $f$. prison, carcer, carceris, $m$. private, prīvātus, -a, -um. privilege, venia, -ae, $f_{\text {.; }}$ iūs, iūris, n.; lībertās, -tātis, $f$. proceed, prōcēdō, -ere, -cessīi, -cessum; prōgredior, -gredī, -gressus sum.

product, frūctus, -ūs, $m$.

prominence (of), summus, -a, -um, adj.

promise, make a promise, polliceor, èrī, pollicitus sum.

proof, indicium, $-\overline{\mathbf{1}}, n$.

property, bona, -ōrum, n. $p l$; fortūnae, -ārum, $f . p l$.

propose a law, lēgem rogō, -āre, -āvī, -ātum.

proposal, sententia, -ae, $f$.

prosecute, persequor, -sequī, -secūtus sum.

protect, dēfendō, -ere, -fendī, -fēnsum; tueor, -ērī, tūtus sum; mūniō, -īre, -īvī, -îtum.

protection, praesidium, -ī, n.; mūnītiō, -ōnis, $f$. proof, indicium, $-\overline{1}, \mathrm{n}$. prove, doceō, -ēre, -uī, doctum. provide, decree, sanciō, -ĩre, sānxī, sānctum. Of a law.

provide for, prōvideō, -ēre, -vīdī, -vīsum.

provided only, dum modo, tantum modo. Cf. 290.

province, prōvincia, -ae, $f$.

provoke, lacessō, -ere, -īvī, -ìtum. public, pūblicus, -a, -um.

punish, ulcīscor, ulcīscī, ultus sum; punish with death, morte multō, -āre, -āvī, -ātum. Cf. inflict and punishment.

punishment, poena, -ae, $f_{\text {; }}$; supplicium, $-\overline{\mathbf{I}}, n$.

punishment on some one (inflict), dē aliquō supplicium sūmō, -ere, sūmpsī, sūmptum; in aliquem animadvertō, ere, 
rertī, -versum; aliquem supliciō afficiō, -ere, -fēcī, -fectum. pu pose, cōnsilium, -ī, n.; mēns, 1 lentis, $f$.

ptis pose of (for the), causā or ' ratiā preceded by the genitive. ('). 126. ad, prep. with acc. , ase.

put pose (to no), in vain, frūstrā; iēquīquam.

pu:sue, sequor, sequī, secūtus ;um; subsequor; innsequor. pursuit, vocation, studium, $-\overline{1}, n$. put, pōnō, -ere, posuī, positum. put an end to, fīnem faciō, with the gen.

put aside, dēpōnō, -ere, -posuī, -positum.

put in charge of, put in command of, praeficiō, -ere, -fēcī, -fectum. Cf. 83-84.

put to death, interficiō, -ere, -fēcī, -fectum.

put to flight, in fugam dō, dare, dedī, datum; in fugam coniciō, -ere, -iēcī, -iectum; fugō, -āre, -āvī, -ātum.

\section{Q}

( uaestor, quaestor, -ōris, $m$. cuality (good), virtūs, -tūtis, $f$. (uantity, vīs, (vis), $f$.

(uarters (winter), hïberna, -ōrum, n. $p l$.

'(uestion, rēs, reī, $f$; causa, -ae, $f$. '[uestion of something (be a), dē aliquā rē agitur. [uick, celer, celeris, celere. juickly, celeriter; as quickly as possible, quam celerrimē. Quintus, Quintus, $-\bar{i}, m$.
R

race, genus, generis, n.; gēns, gentis, $f . ;$ nātiō, -ōnis, $f$.

raise, tollō, -ere, sustulī, sublātum.

rampart, vāllum, $-\overline{1}, n$.

rank, ōrdō, ōrdinis, $m$.

ransom, redimō, -ere, -ēmī, -ēmptum.

rashly, temerē.

rather, potius; magis.

reach, arrive at, perveniō, -īre, -vēnī, -ventum, with ad or in; adveniō, -īre, -vēnī, -ventum, with ad or in; reach (a harbor, etc.), capiō, -ere, cēpī, captum.

read, legō, -ere, lēgī, lēctum.

ready, parātus, -a, -um.

realize, sentiō, -īre, sēnsī, sēnsum. really, vērē; rē vērā.

rear (from the or in the), ā tergō;

$\bar{a}$ novissimō āgmine.

rear of the army, novissimum āgmen; those in the rear, novissimī, -ōrum, $m$. pl.

reason, causa, -ae, $f . ;$ for this reason, quā dē causā; quā rē; quam ob rem.

recall, call back, revocō, -āre, -āvī, -ātum.

recall, recollect, recordor, -ārī, -ātus sum. Cf. 116, 4.

receipt of this news (on) $=$ this thing having been announced. Cf. 369 .

receive, accipiō, -ere, -cēpī, -ceptum; recipiō, -ere, -cēpī, -ceptum.

recently, nūper.

recognize, āgnōscō, -ere, āgnōvi, āgnitum. 
records, tabulae, -ārum, $f . p l$. recount, mention, commemorō, -āre, -āvī, -ātum.

recover one's self, mē recipiō, -ere, -cēpī, -ceptum.

reënforcement, subsidium, -ĩ, $n$.; auxilium, $\overline{\mathbf{i}}, n$.

refer, referō, -ferre, rettulī, re-

lātum; dēferō, -ferre, -tulī, -lātum.

refuse, recūsō, -āre, -āvī, -ātum.

Cf. 269-270. say . . not, negō, -āre, -āvī, -ātum. Cf. 335 . regard, aspiciō, -ere, aspexī, aspectum.

regarding, dē, prep. with abl. case. region, regiō, -ōnis, $f_{\text {; }}$ loca, -ōrum, $n . p l$.

reign, rēgnō, -āre, -āvī, -ātum. rejoice, gaudeō, -ēre, gāvīsus sum; laetor, -ārī, -ātus sum. relief, subsidium, $-\overline{\mathbf{1}}, n$. ; auxilium, $-\overline{1}, n$.

relieve, levō, -āre, -āvī, -ātum. relying on, frētus, $-a,-u m$. Cf. 137.

remain, maneō, -ēre, mānsī, mānsūrus; remaneō; resistō, -ere, -stitī, -

remains (it), restat, -stāre, -stitit

ut; reliquum est ut. Cf. 264 . remember, meminī, - Cf. 116.

memoriā teneō, -ēre, -uĩ, tentum. Remi, Rēmī, -ōrum, m. pl.

remind, moneō, -ēre, -uī, -itum; admoneō; commonefaciō, -ere, -fēcī, -factum. Cf. 117.

remove, dēmoveō, -ēre, -mōvī, -mōtum.

render satisfaction, satisfaciō, -ere, -fēcī, -factum. renew, redintegrō, -āre, -āvī, -ātum; renovō, -āre, -āvī, -ātum. repair, reficiō, -ere, -fēcī,-fectum. repent, paenitet, paenitēre, paenituit. Cf. 118-119.

reply (noun), respōnsum, -ī, n.; make a reply, respondē, -ēre, -spondī, -spōnsum.

reply (verb), respondeō, -ēre, -spondī, -spōnsum. With dat. case.

report (noun), nūntius, -ī, $m$. report (verb), nūntiō, -āre, -āvī, -ātum; referō, -ferre, rettulī, relātum.

republic, rēs pūblica, rē̄ pūblicae, $f$.

repulse, repel, repellō, -ere, -pulī, -pulsum; reiciō, -ere, -iēcī, -iectum.

reputation, opīniō, -ōnis, f.; fāma, -ae, $f$.

rescue, ēripiō, -ere, -ripuī,-reptum. residence, domicilium, $-\overline{1}, n$. resign, mē abdic j, -āre, -āvī, -ātum. Cf. 149.

resist, resistō, -ere, -stitī, resolve, cēnseō, -ēre, cēnsuī, cēnsum.

response, respōnsum, -ī, $n$.

rest (the), cēterī, -ōrum, m. pl.; reliquĩ, -ōrum, m. pl.

rest of (the), reliquus, $-a,-u m$. Cf. 108. cēterī, -ae, -a, $p l$. restore, restituō, -ere, -stituī, -stitūtum.

restrain, retineō, -ere, -uī, -tentum; coerceō, -ēre, -uī, -itum; prohibeō, -ēre, -uī, -itum; dēterreō, -ēre, -uī, -itum. Cf. 269-270. 
$r$ sult is (the), fit, fierī, factum est. Cf. 264.

I t tain, teneō, -ēre, -ūī, tentum; retineō, -ēre, -uī, -tentum.

I' tire, retreat, mē recipiō, -ere, -cēpi, -ceptum; pedem referō, -ferre, rettulī, relātum.

r :turn, give back, reddō, -ere, reddidī, redditum.

turn, go back, come back, redeō, -īre, -iī, -itum; revertor, revertī, revertī or reversus sum. r sturn, send back, remittō, -ere, -mīsī, -missum.

return for (in), prō, prep. with abl. case.

reveal, patefaciō, -ere, -fēcī, -factum; inlūstrō (illūstrō), -āre, -āvī, -ātum.

revenue, vectīgal, -ālis, $n$.

revolution, novae rēs, novārum rērum, f. $p l$; nova imperia, novōrum imperiōrum, $n$. $p l$.

reward, praemium, -ī, n.; frūctus, -ūs, $m$.

Rhine, Rhēnus, $-\overline{1}, m$.

Rhegium, Rhēgium, $-\overline{1}, n$.

Rhone, Rhodanus, $-\overline{1}, m$.

rich, dīves, dīvitis; locuplēs, locuplētis.

right (adj.), dexter, dextra, dextrum; on the right wing, $\bar{a}$ dextrō cornū.

right (noun), iūs, iūris, $n$.

rightly, iūre.

rise, surgō,-ere, surrēxī, surrēctum. risk, perīculum, -ī, $n$.

river, flūmen, flūminis, $n$. road, via, -ae, $f . ;$ iter, itineris, $n$. Roman, Rōmānus, -a, -um; as a noun, Rōmānus, $-\overline{1}, m$.
Rome, Rōma, -ae, $f$.

Romulus, Rōmulus, $-\bar{i}, m$.

route, iter, itineris, $m$.

royal, rēgius, -a, -um.

royal power, rēgnum, -ī, $n$.

ruin, ruina, -ae, $f$.

rule (noun), imperium, -ī, $n$.

rule (verb), imperō, -āre, -āvī, -ātum. Cf. 79-82. rēgnō, -āre, -āvī, -ātum; regō, -ere, rēxī, rēctum.

rumor, rūmor, -ōris, $m$.

run, currō, -ere, cucurrī, cursum.

run forward, prōcurrō, -ere, -currī, -cursum; praecurrō.

\section{$\mathrm{S}$}

Sabinus, Sabīnus, $-\bar{i}, m$.

Sabis, Sabis, -is, m., the river Sambre.

sacred, sānctus, -a, -um.

safe, tūtus, -a, -um; incolumis, -e; salvus, -a, -um.

safely, tūtō. safety, salūs, -ūtis, $f$.

sail, set sail, (nāvem) solvō, -ere, solvī, solūtum; nāvigō, -āre, -āvì, -ātum.

sailor, nauta, -ae, $m$. sake of (for the), causā or gratiā preceded by its genitive. Cf. 126. sally, ēruptiō, -ōnis, $f$.

same, idem, eadem, idem. Cf. $37,43$.

satisfaction (render), satisfaciō, -ere, -fēcī, -factum.

save, servō, -āre, -āvī, -ātum; cōnservō, -āre, -āvī, -ātum; ēripiō, -ere, -uī, -reptum.

say, dīcō, -ere, dĩxī, dictum; say . . . not, negō, -āre, -āvĩ, -ātụm. 
Cf. 335. With direct quotations, I say, inquam; he says, inquit; they say, inquiunt. Cf. 412,3 . scarcely, vix; ferē.

scheme, cōnsilium, -ī, n.; insidiae, -ārum, $f . p l$.

Scipio, Scīpiō, -ōnis, $m$. scoundrel, improbus, -ī, m.; scelerātus, -ī, m.; that scoundrel, iste, istius. Cf. 32 .

scout, explōrātor, -ōris, $m$. sea, mare, maris, $n$.; on land and sea, terrā marīque. Cf. 189. seacoast, ōra maritima, ōrae maritimae, $f$.

second, alter, altera, alterum; secundus, -a, -um. secretly, occultō; sēcrētō. secure, adsequor, -sequī, -secūtus sum; nancīscor, -ī, nāctus (nānctus) sum.

Seduni, Sedūnī, -ōrum, m. pl . see, videō, -ēre, vīdī, vīsum; catch sight of, cōnspiciō, -ere, -spexī, -spectum.

see to it, prōvideō, -ēre, -vīdī, -vīsum.

seek, petō, -ere, -īvī, -ītum; seek for, quaerō, -ere, quaesīvī, quaesītum.

seem, videor, -ērī, vīsus sum.

seems best (it), vidētur, vidērī, vīsum est. Cf. 325, 1.

seize, occupō,- āre, -āvī, -ātum; of persons, capiō, ere, cēpī, captum; comprehendō, -ere, -prehendī, -prehēnsum.

self (intensive pron.), ipse, -a -um. Cf. 38. reflexive pron. Cf. 19-25. self-restraint, temperantia, -ae, $f$.; continentia, -ae, $f$.
Sempronian, Semprōnius, -a, -um. senate, senātus, -ūs, $m$.

senator, senātor, -ōris, m.; senators, patrēs cōnscrīptī, patrum cōnscrīptōrum, $m . p l$, the regular term employed in addressing the senators.

send, mittō, -ere, mīsī, missum; send as lieutenant or legate, lēgō, -āre, -āvī, -ātum.

send ahead, praemittō, -ere, -mīsī, -missum.

send away, dīmittō, -ere, -mīsī, -missum.

send back, remittō, -ere, -mīsī, -missum.

send for, summon, arcessō, -ere, -ivì, -itum.

send forth, send out, ēmittō, -ere, -mīsī, -missum; èiciō, -ere, èiēcī, ēiectum.

send forward, praemittō, -ere, -mīsī, -missum.

Senones, Senonēs, -um, m. pl.

sentiment, sententia, -ae, $f$.; entertain a sentiment, sentiō, -īre, sēnsī, sēnsum.

separate, dīvidō, -ere, -vīsī, -vīsum.

Sequanian, Sēquanus, -i, $m$.

serious, gravis, -e.

Sertorius, Sertōrius, -ī, m.; of or with Sertorius, Sertōriānus, -a, -um.

serve, serviō, -īre, -īvī, -ītum. Cf. 79-82.

service, beneficium, -ī, n.; officium, $-\overline{1}, n$.

set (a day, etc.), dīcō, -ere, dīxī, dictum; cōnstituō, -ere, -stituī, -stitūtum.

set about, mōlior, -īrī, -ītus sum. 
s t before, prōpōnō, -ere, -posuĩ, -positum; expōnō, -ere, -posuī, -positum.

§ st forth, start out, set out, proficīscor, -ī, profectus sum; set forth, relate, expōnō, -ere, -posui, -positum.

set free, lỉberō, -āre, -āvī, -ātum. set sail, (nāvem) solvō, -ere, solvī, solūtum; nāvigō, -āre, -āvī, -ātum.

set up, collocō, -āre, -āvī, -ātum; cōnstituō, -ere, -stituī, -stitūtum.

settle, encamp, cōnsīdō, -ere, -sēdī, -sessum.

settle, put an end to, cōnficiō, -ere, -fēcī, -fectum.

seven, septem, indecl. numeral. seventh, septimus, -a, -um. seventy, septuāgintā, indecl. numeral.

several, complūrēs, -plūra (-ia); multī, -ae, -a; aliquot, indecl. adj.

severe, sevērus -a, -um; vehemēns, -entis; ācer, ācris, ācre; gravis, $-\mathrm{e}$.

sevérity, sevēritās, -tātis, $f$. sharer, socius, -ī, m.; particeps, participis, $m$. Cf. 113-114.

sharp, ācer, ācris, ācre.

sharply, ācriter.

shield, scūtum, -ī, $n$.

ship, nāvis, -is, $f$.; ship of war, nāvis longa, $f$.

shore, litus, litoris, n.; shore (of the sea), ōra, -ae, $f$.

short, brief, of time, brevis, -e. should, oportet, oportēre, oportuit. Cf. 325, 2. dēbeō, -ēre, -uĩ, -itum. Expressed by the passive periphrastic. $\quad$ Cf. 383. In conditions. Cf. 309-310, 356.

shoulder, umerus, $-\overline{1}, m$.

shout, (noun), clāmor, -ōris, $m$.

shout, (verb), clāmō, -āre, -āvī, -ātum; conclāmō, -āre, -āvī, -ātum.

shouting, clāmor, -ōris, $m$.

show, employ, ūtor, ūtī, ūsus sum. Cf. 165.

show, teach, doceō, -ēre, -uī, doctum; dēmōnstrō, -āre, -āvī, -ātum; ostendō, -ere, ostendī, ostentum; display, ostentō, -āre, -āvī, -ātum.

show gratitude, grātiam referō, -ferre, rettulī, relātum.

shudder at, horreō, -ēre, -uī, - . Cf. 60.

shut in, hem in, contineō, -ēre, $-u \bar{i}, \quad$-tentum; inclūdō, -ere, -clūsī, -clūsum.

shut off, interclūdō, -ere, -clūsī, -clūsum; prohibeō, -ēre, -uī, -itum. Cf. 147-148.

Sicily, Sicilia, -ae, $f$. side, latus, lateris, n.; on both sides, ab utrōque latere; from or on all sides, undique; omnibus ex partibus

siege, oppūgnātiō, -ōnis, f.; obsidiō, -ōnis, $f$.

sight, cōnspectus, -ūs, m.; aspectus, -ūs, $m$.

sight of (catch), cōnspiciō, -ere, -spexī, -spectum; cōnspicor, -ārī, -ātus sum.

signal, signum $-\overline{1}, n$.

Silanus, Sīlānus, $-\overline{1}, m$. 
silent (be), sileō, -ēre, -uī, -; keep silent, taceō, -ēre, -uī, -itum.

Silvanus, Silvānus, $-\bar{i}, m$. silver, argentum, $-\overline{1}, n$. since, cum. Cf. 292. not long since, paulō ante; nūper. single, ūnus, -a, -um. situated, positus, -a, -um. six, sex, indecl. numeral. six hundred sixth, sēscentēsimus sextus.

six hundred tenth, sēscentēsimus decimus.

sixteenth, sextus decimus. sixth, sextus, -a, -um. sixtieth, sexāgēsimus, -a, -um. size, māgnitūdō, -dinis, $f$. skilled, skillful, perītus, -a, -um. Cf. 113-114.

slaughter (noun), caedēs, -is, $f$. slaughter (verb), trucīdō, -āre, -āvī, -ātum; occīdō, -ere, -cīdī, -cīsum.

slave, servus, $-\overline{\mathbf{i}}, m$.

slavery, servitūs, -tūtis, $f$. slay, occīdō, -ere, -cīdī, -cīsum.

Cf. kill.

slip away or from, èlābor, -lābī, -lāpsus sum; effugiō, -ere, -fūgī, -fugitum.

small, parvus, $-\mathrm{a},-u m$.

snatch from, ēripiō, -ere, -uī, -reptum.

so, ita; tam; sīc.

so (and), itaque.

so great, tantus, -a, -um.

so many, tot, indecl. noun and adj.; tam multī, -ae, -a.

so many times, totiēns, $a d v$.

so much, tantus, -a, -um. soldier, mīles, mīlitis, $m$.

some, aliquis (-quī), -qua, -quid

(-quod); quis, qua, quid (quod); nōnnüllī, -ae, a; some ... others, alīi . . . alīi. Cf. 56 .

some one, aliquis; quis; quispiam.

Cf. $47-48,50$.

something, aliquid, quid. Cf. 4748.

sometimes, nōnnumquam, $a d v$.

son, fîlius, $-\bar{i}, m$.

soon, mox; brevī tempore.

soon as (as), cum prïum; ut prīmum.

soon as possible (as), quam prïmum.

sorrow, dolor, -ōris, $m$.

sort, modus, -ī, m.; genus, generis, $n$.; of this sort, eius modī.

Sotiates, Sotiātēs, -um, m. pl.

source of revenue, frūctus, -ūs, $m$.

Spain, Hispānia, -ae, f.; of Spain,

in Spain, of the Spaniards, with the Spaniards, Hispāniēnsis, -e, adj.

spare, parcō, -ere, pepercī, 一. Cf. 79-82.

speak, loquor, loquī, locūtus sum; dīcō, -ere, dīxī, dictum.

speech, ōrātiō, -ōnis, $f_{\text {; ; }}$ deliver a speech, ōrātiōnem habeō, -ēre, -uī, -itum.

speed, celeritās, -tātis, f.; with

horse at full speed, equō admissō (incitātō).

spend, use up, cōnsūmō, -ere, -sūmpsī, -sūmptum.

spend, pass, of time, exigō, -ere, -ēgì, -āctum.

spite of the fact that (in), quamquam; cum. Cf. $315,317$. 
s lendid, pulcherrimus, $-\mathrm{a},-\mathrm{um}$.

$\S$ sonsor, auctor, -ōris, $m$.

s pot, locus, $-\overline{\mathbf{1}}, m$. (n. in pl.).

؟ pring up, orior, -îrī, ortus sum; coörior, -īrī, -ortus sum.

? take (be at), passive of agō, -ere, ēgī, āctum.

tand around, circumsistō, -ere, -stetī, -

'tandard, sīgnum, -ī, n.; aquila, -ae, $f$., (eagle).

standard bearer, aquilifer, -ī, m.; is quī aquilam fert; sīgnifer, $-\bar{i}, m$.

start, set out, proficīscor, $-\overline{\mathrm{i}}$, profectus sum.

state (noun), cīvitās, -tātis, f.; the Roman state, rēs pūblica, reī pūblicae, $f$.

state (verb), dīcō, -ere, dīxī, dictum; cōnfīrmō, -āre, -āvì, -ātum.

statement, ōrātiō, -ōnis, $f$. station (noun), locus, $-\overline{1}, m$. (n. in $p l$.$) .$

station (verb), collocō, -āre, -āvī, -ātum.

statue, simulācrum, -ī, n.; sīgnum, $-\overline{1}, n$.

stay, maneō, ēre, mānsī, mānsūrus; remaneō.

steep, arduus, -a, -um.

still, nevertheless, tamen.

still, up to this time, adhūc, etiam nunc; up to that time, etiam tunc.

stir up, agitō, -āre, -āvī, -ātum; incitō, -āre, -āvī, -ātum; concitō. stone, saxum, -ī, n.; lapis, lapidis, $m$.

stop, halt, resistō, -ere, -stitī, - ; cōnsistō, -ere, -stitī, - store up, condō, -ere, condidī, conditum.

storm (noun), tempestās, -tātis, $f$.; hiems, hiemis, $f$.

storm (verb), take by storm, expūgnō, -āre, -āvī, -ātum.

storming, oppūgnātiō, -ōnis, $f$. strategy, dolus, -ī, m.; insidiae, -ārum, $f . p l$.

strength, rōbur, rōboris, $m$.

strengthen, cōnfīrmō, -āre, -āvī, -àtum.

strip, spoliō, -āre, -āvī, -ātum; nūdō, -āre, -āvī, -ātum. Cf. 149.

strong, fïrmus, -a, -um.

strong (be), valeō, -ēre, -uī, -itūrus; possum, posse, potuī, - Cf. 66 . strongly fortified, mūnïtissimus, -a, -um.

study, studium, $-\overline{\mathrm{i}}, n$. style, genus, generis, $n$.

Suabians, Suēvī, -ōrum, m. pl. subdue, pācō, -āre, -āvī, -ātum; superō, -āre, -āvī, -ātum.

subject (noun), rēs, reī, f.; causa, -ae, $f$.

subject (verb), subiciō, -ere, -iēcī, -iectum.

subjugate, pācō, -āre, -āvī, -ātum. success, fēlīcitās, -tātis, $f$.

successful, of things, secundus, -a, -um; of persons, fēlīx, fēlīcis. successfully, fēlīciter; bene; cum fēlīcitāte.

succession (in), continuus, -a, -um, adj.

such, is, ea, id. Cf. 274-275, 569. such, of such a character, tālis, -e; ēius modī. Cf. 102. such, so great, tantus, -a, -um; 
such . . . as, tālis . . . quālis; tantus... quantus.

such important, tantus, -a, -um. sudden, subitus, -a, -um; repentīnus, -a, -um.

suddenly, subitō; repente. sue for, petō, -ere, -īvī, -îtum.

Suessiones, Suessiōnēs, -um, $m$. $p l$.

suffer, ferō, ferre, tulī, lātum; perferō, -ferre, -tulī, -lātum; patior, patī, passus sum.

suffer harm, dētrīmentum capiō, -ere, cēpī, captum.

suffer punishment, suppliciō afficior, afficī, affectus sum; poenās dō, dare, dedī, datum; poenās pendō, -ere, pependī, pēnsum; poenās persolvō, -ere, -solvī, -solūtum.

sufficient, satis, indecl. noun. 105.

sufficiently, satis, $a d v$.

Sugambri, Sugambrī, -ōrum, m. pl. suitable, suited, aptus, -a, -um; accommodātus, -a, -um. Cf. 92-93.

Sulla, Sulla, -ae, $m$.

summer, aestās, -tātis, $f$.

summon, vocō, -āre, -āvī, -ātum; convocō, -āre, -āvī, -ātum; arcessō, -ere, -īvī, -ìtum. sun, sōl, sōlis, $m$.

sunset, occāsus sōlis (occāsus, -ūs, $m$.).

suppliant, supplex, -plicis, $m$. or $f$. supply, cōpia, -ae, $f_{\text {.; }}$ supplies, commeātus, -ūs, m., commonly used in the sing.; grain supply, rēs frūmentāria, reī frūmentāriae, $f$. suppose, crēdō, -ere, crēdidī, crē. ditum; putō, -āre, -āvī, -ātum. suppress, opprimō, -ere, -pressī, -pressum; comprimō, -ere, -pressī, -pressum.

supremacy, imperium, $-\mathbf{i}, \mathrm{n}$. supreme, summus, -a, -um.

surely, prōfectō; certē; quidem; sānē.

surpass, superō, -āre, -āvī, -ātum; excellō, -ere, -, -celsum. With dat.

surrender (noun), dēditiō, -ōnis, $f$. surrender (verb), dēdō, -ere, dē, didī, dēditum; trādō, -ere, -didī, -ditum.

surround, come around, circumveniō, -īre, -vēnī, -ventum. Cf. 62 .

surround, place around, circumdō, -dare,-dedī,-datum. Cf. 78, $a$. surround, stand around, circumsistō, -ere, -stetī, -. Cf. 62. survive, supersum, -esse, -fuī, -futūrus.

suspicion, suspiciō, -ōnis, $f$.

sustain, sustineō, -ēre, -ūi, -tentum. swamp, palūs, palūdis, $f$.

sway, imperium, -î, $n$.

swiftness, celeritās, -tātis, $f$. sword, gladius, $-\overline{1}, m$.

Syracuse, Syrācūsae, -ārum, $f . p l$.

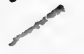

\section{$\mathrm{T}$}

take, of animate beings, dūcō, -ere, dūxī, dućcum; of things, ferō, ferre, tulī, lātum; portō, -āre, -āvī, -ātum; receive, capiō, -ere, cēpī, captum; accipiō.

take away, ēripiō, -ere, -uī, -reptum. 
ake fright, pertimēscō, -ere, that (conj.), ut. Cf. 254, 257, 262, -timui, -

ake place, passive of gerō, -ere, gessī, gestum.

ake up, suscipiō, -ere, -cēpī, -ceptum.

ake vengeance on, ulcīscor, -i, ultus sum.

talent, ingenium, $-\overline{\mathbf{l}}, n$.

Tarentum, Tarentum, -ī, $n$.

task, negōtium, -i, n.; opus, operis, n.; rēs, rē̄, $f$.

tax, stīpendium, $-\overline{1}, n$.

teach, doceō, -ēre, -uī, doctum; praecipiō, -ere, -cēpī, -ceptum. Cf. 70, 72 .

tell, dīcō, -ere, dīxī, dictum; with dat.; nārrō, -āre, -āvī, -ātum; tell, explain, expōnō, -ere, -posuī, -positum.

ten, decem, indecl. numeral.

Tencteri, Tencterī, -ōrum, m. pl. tenth, decimus, -a, -um.

term, verbum, -ī, n.; terms, conditions, condiciō, -ōnis, $f$. terrify, terreō, -ēre, -uī, -itum; perterreō.

territory, fīnēs, -ium, m. $p l$. testimony, indicium, $-\overline{1}, n$. than, quam. Cf. 157-159. thank, grātiās agō, -ere, ēgī, āctum. With dat.

thankful (be), grātiam habeō, -ēre, -uī, -itum. With dat.

thanks (render), grātiās agō, -ere, ègī, āctum. With dat.

thanksgiving, supplicātiō, -ōnis, $f$. that (pron.), ille, -a, -ud. Cf. 33. is, ea, is. Cf. 36 . that of yours, iste, -a, -ud. Cf. 31 . that is, hōc est.

264, 265. nē. Cf. 266. quīn. Cf. 272. would that, utinam. Cf. 226-231.

that not, nē. Cf. 254, 262, 265. ut nōn. Cf. 259, 264, 265. ut. Cf. 266, 267.

the ... the, with comparatives, quantō ... tantō; quō ... hōc (eō). Cf. 162 .

their (reflexive adj.), suus, -a, -um; when not reflexive, eōrum, or eārum. Cf. 19-25.

themselves (intensive pron.), ipsī, -ae, -a; reflexive pron., - , suĩ. Cf. 19-25.

then, at the time, tum; tunc; eō tempore; then, resumptive, igitur. Cf. 412. In enumerations, then, next, in the second place, deinde.

thence, then, inde.

there, in that place, ibi; there, to that place, thither, eō. There, the expletive, is not expressed.

therefore, itaque; igitur. Cf. 412. quā rē; quam ob rem; quae cum ita sint.

thing, rēs, reī, $f$.

think, putō, -āre, -āvī, -ātum; arbitror, -ārī, -ātus sum; existimō, -āre, -āvī, -ātum.

think of, cōgitō, -āre, -āvī, -ātum. third, tertius, -a, -um.

thirteenth, tertius decimus. thirty, trīgintā, indecl. numeral. this, hīc, haec, hōc; is, ea, id. thoroughly frighten, perterreō, -ēre, -uĩ, -itum.

though. Cf. although.

thousand (a), mille, indecl. nu- 
meral; (more than one) thou-| to, ad or in, preps. with acc.; sand, milia, -ium, n. pl. With partitive gen. Cf. 494, 3.

thousands, milia, -ium, n. $p l$. With partitive gen. Cf. 494, 3 . threaten, minor, -ārī, -ātus sum; immineō, -ēre, -uī, -; impendeō, -ēre, -, - C. Cf. 79-80. threats, minae, -ārum, f. pl.; threats of force, vīs et minae. three, trēs, tria.

three hundred, trecentī, -ae, -a. three years, a period of three years, triennium, $-\overline{\mathbf{1}}, n$. through, throughout, per, prep. with acc. case.

throw, iaciō, -ere, iēcī, iactum; coniciō, -ere, -iēcī, -iectum.

throw into confusion, perturbō, -āre, -āvī, -ātum.

thrust at, appetō, -ere, -īvī, -ìtum. thus, ita; sīc.

thwart, obstō, -āre, -stitī, - .

tide, aestus, -ūs, $m$.

till (verb), colō, -ere, coluī, cultum. till, úntil (prep.), (ūsque) ad;

in, prep. with acc. case. till, until, conj., dum. Cf. 288. time, tempus, temporis, n.; at that time, tum; tunc; eō tempore; for a long time, for some time, iam diū; iam dūdum; iam prīdem; for the first time, primum; a second time, iterum; up to this time, adhūc, ad id tempus. times (how many), quotiēns, $a d v$. times (so many), totiēns, $a d v$. timid, timidus, -a, -um. tire, be tired of, piget, pigēre, piguit. Cf. 118.

Titurius, Titūrius, $-\overline{1}, m$. expressed by the dat.

to, sign of the infinitive.

to no purpose, frūstrā, $a d v$.; nēquĩquam, $a d v$.

to-day ( $a d v$.$) , hodiē.$

to-day (noun), hodiernus diēs, $m$. together. Cf. 26.

together with, ūnā cum with the abl.

toil, labor, -ōris, $m$.

too, also, etiam; quoque. Cf. 412. too, excessively, $a d v$., nimis.

too great, nimius, -a, -um.

too much (noun), nimium, $-\overline{1}, n$. too much (adj.), nimius, -a, -um. top of, summus, -a, -um, adj. Cf. 108.

toward, of space, ad or in, prep. with acc. case; of feeling, ergā or in, preps. with acc. case.

tower, turris, -is, $f$.

town, oppidum, $-\overline{\mathbf{i}}, n$.

training, exercitātiō, -ōnis, $f$.

transport (noun), freight ship, nāvis onerāria, $f$.

transport (verb), trānsportō, -āre, -āvī, -ātum. Cf. 62-63.

treachery, insidiae, -ārum, $f . p l$.

treat, discuss, agō, -re, ēgī, āctum.

tremble at, tremō, -ere, -uī, With acc. Cf. 60.

trial, court trial, iūdicium, $\overline{\mathbf{i}}, n$.; case under trial, rēs, reī, $f$; causa, -ae, $f$.

trial, test, perīculum, $-\overline{\mathbf{1}}, n$.

tribe, gēns, gentis, $f$.

tribune, tribūnus, $-\overline{1}, m$.

tributary, vectīgālis, -e; as a noun, vectīgālis, -is, $m$. 
t: ibute, tax, vectīgal, -ālis, $\boldsymbol{n}$. ibute, reward, praemium, -ī, $n$.

t iumph (celebrate a), triumphō, -āre, -āvī, -ātum; . . over some one, ... dē aliquō. t:oops, cōpiae, -ārum, f. pl.; mīlitēs, -um, m. pl.

true, Qērus, -a, -um.

truly, vêrō; certē; sānē; quidem. trust, cōnfīdō, -ere, cōnfīsus sum. Cf. 79-82.

1ruth, vērum, -ī, n.; vēritās, -tātis, $f$.

ry, cōnor, -ārī, -ātus sum; temptō, -āre, -āvī, -ātum.

Tulingi, Tulingī, -ōrum, m. pl. Tullius, Tullius, $-\overline{\mathbf{1}}, m$. turn, vertō, -ere, vertī, versum; convertō, -ere, -vertī, -versum; turn, face about, tergum vertō. turn aside, āvertō, -ere, -vertī, -versum.

twelfth, duodecimus, -a, -um. twelve, duodecim, indecl. numeral. twenty, vīgintī, indecl. numeral. twenty-three, trēs et vīgintī or vīgintī trēs. Trēs must be declined. Cf. three.

twenty-five, quīnque et vīgintī or vīgintī quīnque, indecl. numeral.

two, duo, duae, duo; the other of two, alter, altera, alterum; which of two, uter, utra, utrum. Cf. 45 .

tyrant, tyrannus, $-\bar{i}, m$.

\section{U}

Ubii, Ubīi, -ōrum, $m . p l$. unable (be), nōn possum, posse, potuī, - unarmed, inermis, -e. uncertain, incertus, -a, -um. under, sub, prep. with acc. and abl. cases.

under the leadership of, use the abl. abs. Cf. 370 .

under these circumstances, quae cum ita sint.

undergo, subeō, -īre, -iī, -itum.

understand, intellegō, -ere, -lēxi, -lēctum.

undertake, suscipiō, -ere, -cēpī, -ceptum.

undisturbed, quiētus, -a, -um.

unfavorable, inīquus, $-a,-u m$; aliēnus, -a, -um.

unfortunate, miser, misera, miserum.

unfortunately it happens, accidit accidere, accidit. Cf. 264.

unfriendly, inimīcus, -a, -um. Cf. $92,95$.

unharmed, incolumis, -e; tūtus, -a, -um; salvus, -a, -um; integer, -gra, -grum.

united (be), be in harmony, cōnsentiō, -īre, -sēnsī, -sēnsum; passive of coniungō, -ere, -iūnxī, -iūnctum.

unjustly, iniūriā, $a d v$. unless, nisi. Cf. 299, 2. unlike, dissimilis, -e. Cf. 92. unpopularity, invidia, -ae, $f$.

unprotected, open, exposed, apertus, -a, -um.

unskilled, imperïtus, -a, -um.

Cf. 113-114.

until (prep.) ad or in with acc. case. until, (conj.), dum; dōnec; quoad.

Cf. 288.

unusual, novus, -a, -um; in- 
ūsitātus, -a, -um; singulāris, -e; ègregius, -a, -um.

unwilling (be), nōlō, nōlle, nōluī,

unwillingly, use the adj., invitus, $-a,-u m$.

unworthy, indignnus, -a, -um. Cf. 145.

up to, üsque ad, prep. with acc.

case; up to this time, adhūc; ad id tempus.

upon, in, prep. with acc. and abl. cases. Time when, abl. case. Cf. 167.

uprightness, innocentia, -ae, $f$. urge, hortor, -ārī, -ātus sum.

Cf. 262 .

use (noun), ūsus, -ūs, $m$. use (verb), ūtor, ūtī, ūsus sum.

Cf. 165.

used to. Cf. accustomed. useful, ūtilis, -e. Cf. 92-93. Usipetes, Usipetēs, -um, m. $p l$. utmost, summus, -a, -um.

\section{V}

vacant (be), vacō, -āre, -āvī, ātum.

vain (in), frūstrā; nēquĩquam. valley, vāllēs, -is, $f$. valor, virtūs, -tūtis, $f$. value (of great, etc.). Cf. 122. value (verb), habeō, -ere, -uī, -itum; dūcō, -ere, dūxī, ductum. Cf. 122.

variety, varietās, -tātis, $f$. various, diversus, -a, -um.

Venelli, Venellī, -ōrum, $m . p l$. Veneti, Venetī, -ōrum, m. pl. vengeance on (take), ulcīscor, $-\overline{1}$, ultus sum. With acc. case.
Vercingetorix, Vercingetorix, -igis, $m$.

verse, versus, -ūs, $m$.

very, of adj. and adv. use the superlative; intensive pron., ipse, -a, -um.. Cf. 38.

Vesontio, Vesontiō, -ōnis, $f$;, a town of Gaul. vice, vitium, $-\overline{1}, n$.

vicinity of (in the), ad, prep. with acc. case; to or from the vicinity of. Cf. 198.

victor, victor, -ōris, $m$.

victorious, victor, -ōris.

victory, victōria, -ae, $f$.

village, vīcus, $-\overline{1}, m$.

violence, vīs, (vīs), $f$.; by violence, per vim.

voice, vōx, vōcis, $f$.

Volturcius, Volturcius, $-\mathbf{i}, m$.

vote thanks, grātiās agō, -ere, ēgī, āctum.

\section{W}

wage, gerō, -ere, gessī, gestum.

wait, exspectō, -āre, -āvī, -ātum; moror, -ārī, -ātus sum.

wait for, exspectō, -āre, -āvī, -ātum. Cf. 61.

wall, mūrus, -ī, m.; walls of a city, moenia, -ium, n. pl.

want (noun), inopia, -ae, $f$.

want (verb), volō, velle, voluī, - ; cupiō, -ere, -īvī, -ìtum.

war, bellum, -ī, n.; make war on some one, bellum alicuī inferō, -ferre, intulī, inlātum (illātum); bellum alịcuī faciō, -ere, fēcī, factum; in war, militiae, Cf. 196. warfare, bellum, -ī, n.; rēs mìlitāris, reī mīlitāris, $f$. 
W rn, moneō, -ēre, -uī, -itum; admoneō. Cf. 117.

$\mathrm{W}$ urning (give). Cf. warn.

vv ıste (lay), vāstō, -āre, -āvī, -ātum; populor, -ārī, -ātus sum. watch (noun), vigilia, -ae, $f . ; a$ division of the night. Cf. 175. watch, keep watch (verb), vigilō, -āre, -āvī, -ātum; watch out for, vigilō ad with acc. case. watchful, vigilāns, -antis, dīligēns, -ęntis.

watchfulness, prūdentia, -ae, $f$. ; dìligentia, -ae, $f$.

water, aqua, -ae, $f$. wave, flūctus, -ũs, $m$.

way (in this, such, etc.), ita; sīc. way, manner, modus, -ī, m.; ratiō, -ōnis, $f$.

way, road, via, -ae, $f$.; iter, itineris, $n$.

way with (make), tollō, -ere, sustulī, sublātum. Cf. kill.

weaken, dēbilitō, -āre, -āvī, -ātum. weapon, tēlum, -ī, $n$.

weather, tempestās, -tātis, f.; hiems, hiemis, $f$.

weep, fleō, -ēre, -ēvī, -ètum. weight, onus, oneris, n.; pondus, ponderis, $n$.

weight (have), valeō, -ēre, -uī, -itūrus.

welcome, accipiō, -ere, -cēpī, -ceptum.

welfare, salūs, -ūtis, $f$.

well, bene.

well disposed, bonō animō. Cf. 140.

well known, nōtus, -a, -um.

what (adj.), quī, quae, quod; pron., quid. what sort of, quālis, -e. whatever, whatsoever, pron., quicquid; adj., quĩcumque, quae-, quod-.

when, cum. Cf. 277-282. ubi.

Cf. 283.

whence, unde.

whenever, cum. Cf. 282.

where, in what place, ubi; where,

to what place, quō.

whether, in single questions, num; -ne; in double questions, utrum; -ne. Cf. 221. whether... or, utrum (-ne)... an. Cf. 221. whether . . . or not, utrum . . annōn; utrum ... necne. Cf. 222. whether, to see if, sī. Cf. 251.

which (relative pron. and adj.), quī, quae, quod.

which (interrogative pron.), quis, quid; interrogative adj., quī (quis), quae, quod; which of two, uter, utra, utrum, interrogative pron. and adj. Cf. 45.

while, dum. Cf. 285-287.

while, on the other hand, autem.

Cf. 412.

while (for a long), diū.

while (it is worth), tantī est. Cf.

122. operae pretium est. whither, quō.

who (relative pron.), quī, quae; interrogative pron., quis.

whole, tōtus, -a, -um; ūniversus,

-a, -um; cūnctus, -a, -um; as

a whole, ūniversus, -a, -um. why, cūr; quid; quā rē; quam ob rem.

wicked, improbus, -a, -um; scele- 
rātus, -a, -um; malus -a, -um; nefārius, -a, -um.

wide, lātus, -a, -um.

widely, lātē.

width, lātitūdō, -dinis, $f$; am-

plitūdō, -dinis, $f$.

wife, uxor, -ōris, $f$.; cōniūnx,

cōniugis, $f$.

will (against one's), use invitus,

-a, -um, adj. Cf. 370 .

will, be willing, volō, velle, voluī,

will (good), voluntās, -tātis, $f$.

win over, conciliate, plācō, ,-āre, -āvī, -ātum.

wind, ventus, $-\overline{1}, m$.

wine, vīnum, $-\mathbf{1}, n$.

wing (of an army), cornū, -ūs, $n$.;

on the right (left) wing, $\bar{a}$ dextrē (sinistrō) cornū.

winter (noun), hiems, hiemis, $f$.

winter (verb), hiemō, -āre, -āvī, -ātum.

winter quarters, hīberna, -ōrum, n. $p l$.

wisdom, sapientia, -ae, $f_{. ;}$cōnsilium, -ĩ, $n_{\mathfrak{t}} ;$ prūdentia, -ae, $f$. wise, sapiēns, -entis; a wise man, sapiēns, -entis, $m$.

wish, volō, velle, voluī, -; cupiō, -ere, -ivvì, -itum; not wish, nōlō, nōlle, nōluī, -

with, cum, prep. with abl.; apud, prep. with acc.; abl. of means. Cf. 127. along with, together with, ūnā cum, with abl.

withdraw, discēdō, -ere, -cessī, -cessum; excēdō, -ere, -cessī, -cessum; mē recipiō, -ere, -cēpī, -ceptum.

within, of place, intrā, prep. with acc. case; within, of time, abl. of time. Cf. 167-168.

without, sine, prep. with abl. case; with clauses, ut . . . nōn. Cf. $259, a$.

withstand, sustineō, -ēre, -uĩ, -tentum.

witness, testis, -is, $m$. and $f$. woman, mulier, mulieris, $f$.

wonder, wonder at, mīror, -ārī, -ātus'sum. Cf. 60.

wonderful, mīrābilis, -e.

woods, silva, -ae, $f$.

word, verbum, -ī, $n$.

word of honor, fidēs, -ēi, $f$.

world, orbis terrae or orbis terrārum (orbis, -is, m., circle).

worth while (it is), tanti est;

operae pretium est. Cf. 122.

worthy, dīgnus, -a, -um. Cf. 145, 275,1 .

would that, utinam. Cf. 226231.

wound (noun), vulnus, vulneris, $n$. wound (verb), vulnerō, -āre, -āvī, -ātum.

write, scrībō, -ere, -scrīpsī, scrīptum.

wrong, iniūria, -ae, $f$.

wrong (be), be mistaken, errō, -āre, -āvī, -ātum.

wrongdoer, nocēns, -entis, $m$.

wrongdoing, maleficium, -ī, $n$.

\section{Y}

year, annus, -î, m.; every year, yearly, quotannīs, $a d v$.

yes. Cf. 223-224.

yet, nevertheless, tamen; autem.

Cf. $412,1$.

yet, up to this time, adhūc; etiam 
nunc; up to that time, etiam |your, of one person, tuus, -a, -um; tunc.

yet (not), nōndum.

of more than one person, yield, cēdō, -ere, cessī, cessum.

Cf. 79-82.

you, tū, tuī; vōs, vestrum (vestrī). young man, adulēscēns, -entis, $m$.; iuvenis, -is, $m$. vester, vestra, vestrum.

\section{Z}

zeal, studium, -ī, $n$.

zealous, studiōsus, -a, -um. 



\section{INDEX}

(The numbers refer to sections.)

\section{A}

Ablative absolute, 369-374.

Ablative case, 127-168, 463.

absolute, 369-374.

of accompaniment, 133-134, 463.

of accordance, 138-139, 463 .

of agent, 128-130, 463.

of cause, 135-137, 463 .

of comparison, 157-159.

of degree of difference, 160$162,174,200$.

of description, 140-141.

of manner, 131-132, 463.

of material, 152.

of means or instrument, 127, $129,463$.

of measure or difference, 160162, 174, 200.

of origin, 150-151.

of place whence, 188, 192-194.

of place where, 186, 189.

of price, 163-164.

of respect, 142-145.

of separation, 146-149.

of source, 150-151.

of specification, 142-145, 463 .

of time, 167-168, 170.

with dìgnus and indīgnus, 145. with opus and üsus, 155-156. with ütor, etc., 165-166. with verbs of plenty, etc., 153154.

Abstaining, verbs of, 147-148.

abstineō, 147-148.

absum, construction, 200 .

accēdit ut, 264.

accidit ut, 264 .

accommodātus, 92-93.

Accompaniment, ablative of, 133134, 463.

Accordance, ablative of, 138-139, 463.

Accusative case, 60-77.

cognate accusative, 64 .

direct object, 60-61.

exclamations, 77 .

extent of time and space, 169, 199-200, 452; of degree,

74.

inner object, 65-66.

limit of motion, place to which, 187, 190, 194, 195, 198.

subject of infinitive, 324-325, $333 \mathrm{ff}$.

with compounds of trāns, etc., 62-63.

with verbs of asking, etc., 7072.

with verbs of naming, etc., 6768.

Accusing, verbs of, 121.

accūsō, 121. 
Acquitting, verbs of, 121 . acsī, 313 .

ad-, compounds of, with acc., 62; with dat., 83 .

additur ut, 264.

Adjectives, agreement, 1-3; attributive, 1, $a$; predicate, 1 , $b ; 430$.

as substantives, 3 .

indefinite, 46-56.

reflexive, 19-25.

position of, 402, 407 .

possessive, 27-29.

with dat., 92-96.

with gen., 113-115.

adiuvō, 81 .

admoneō, 117; admoneō ut, 262.

Adverbial acc., 74.

Adverbs, position of, 411 .

Adversative conjunctions, 397.

adversus, 92 .

aequus, 92 .

aestimō, 122 .

Agent, ablative of, 89, 128-130, 388 ; dative of, $88-89,384$, 388.

Agreement of adjectives, 1-3. of nouns, 4-7.

of relative pronoun, 12-15.

of verbs, 8-11.

aliquis, $46-48$.

alius, 56, 494, 4 .

alter, $56,494,4$.

amīcus, 92, 95.

amplius, 159 .

an in questions, 221-222, 398399.

annōn, 222.

Answers, 223-225.

ante-, in compounds, with dat., 83 . antequam, 289.
Apodosis, 298.

of unreal conditions with indicative, 309-310.

appellō, 58, 67-68.

Appointing, verbs of, 67-68.

Apposition, 4-6.

Appositives, 4-6; position of, 408. aptus, 92-93.

Asking, verbs of, 70-72.

attingit ut, 264.

attribuō with gerunđive, 382 .

audeõ, 329. "

autem, postpositive, 412 .

avidus, 113-114.

B

Believing, verbs of, 79-82.

belli, loc., 196.

\section{C}

Cardinal numerals, position of, 406.

cārus, 92 .

Cases. Cf. Ablative, etc.

cāsū, 132 .

causā, 126, 381 .

Causal clauses, 291-297.

Cause, ablative of, 135-137, 463. cēdō, 79-82.

cêlō, 70 .

cēnseō, 262.

Characteristic clauses, 274-276, 569.

circum, in compounds, with acc., 62 ; with dat., 83.

Cities, construction with names of, 193-194, 198.

coepī, 329.

Cognate accusative, 64 .

cõgnōvī, 209-210.

cōgō, 332, 329. 
C. llective nouns, verb agreement, 9.

C mmanding, verbs of, 79-82.

C Immands, 237-241; in indirect discourse, 349 .

(' mmonefaciō, commonefīō, 117.

cr mmoneō, 117.

C smparison, ablative of, 157-159.

C smparison, conditional clauses of, 313 .

Complementary infinitive, 328330 ; position of, 419 .

Complex sentences in indirect discourse, 346-358.

Complex sentences, order of words in, 420-425.

Compound sentences, order of words in, 420-425.

Compound verbs, with acc., 6263 ; with dat., 83-84, 475. con, in compounds, 83. concēdō, 382.

Concessive clauses, 314-322; position of, 422 .

Condemning, verbs of, 121.

Conditional clauses of comparison, 313.

Conditions, 298-312.

logical, 301.

ideal, 303.

unreal, 305-310.

mixed, 308.

in indirect discourse, 351-358. expressed by participle, 312, 371.

cōnferō, 475.

cōnfīdō, 79-82.

Conjunctions, 394-399.

conlocō, 191.

cönor, $329,471$.

cōnscius, 113-114. cōnsequitur ut, 264. cōnsiliō, 139.

cōnstituō, 191, 329.

cōnsuēscō, 329.

cōnsuētūdine, 139.

cōnsuēvī, 209-210.

cōnsulō, 79-82, footnote, p. 15.

contendō, 329 .

contentus, 137.

contineō, 475 .

contingit ut, 264 .

contrārius, 92.

Contrary to fact conditions. Cf. Unreal.

conveniō, 475 .

Convicting, verbs of, 121 .

convocō, 475.

Copulative conjunctions, 394-396.

Correlative conjunctions, 399 .

crēdō, 79-82.

creō, 57-58, 67-69.

cum, causal, 292.

concessive, 315 .

temporal, 277-282.

inversum, 281.

iterative, 282.

cum . . tum, 280, note.

tum, cum, 280.

cunctor, 329 .

cūnctus, 189.

cupidus, 113-114.

cupiō, 332, 262, 329.

cūrō, 382; cūrō ut, 262.

D

Dates, 176-185.

Dative case, 78-96.

of agent, 88-89, 384, 388 .

of indirect object, 78 .

of interest, 87.

of possessor, 85-86. 
Dative case, of purpose, 90-91, 483. of reference, 87.

of service, 90-91.

with adjectives, 92-96.

with compound verbs, 83-84.

with special verbs, $79-82$.

Day, divisions of the, 175 .

dēbeō, 329,585 ; in unreal conditions, 309-310.

dēcernō, 262 .

Definite value or cost, 123.

Degree of difference, ablative of, 160-162, 200.

dēlectō, 81 .

Deliberative subjunctive, 218 . dēligō, 58, 67 .

Demanding, verbs of, 70-72.

Demonstrative pronouns and adjectives, 30-38; position of, 403.

Deponent verbs, participles of, 361 ; periphrastic of, 519 .

Description, genitive of, 101-103, 109; ablative of, 140-141.

dēsinō, 329, 147-148.

Desire, adjectives of, 113-114.

dēsistō, 329, 147-148.

dēspērō, 60 .

dēterreō, 269-270.

dextrā, 189 .

dīcō, 58, 67-68, 329.

dictū, 391 .

Difference, Degree or Measure of, 160-162.

diffĩdō, 79-82.

dignus, 145; dīgnus est quī, 275.

Direct discourse, 467.

Direct object, 60-63.

Direct questions, 214-222.

Direct and indirect reflexives, 2125.
Disjunctive conjunctions, 398. dissimilis, 92 .

Distance, how expressed, 200. distō, 200.

dō, with gerundive, 382 .

doceō, 70-72.

doleō, with acc., 60; with quod, 296 ; with infinitive, 336 .

dolō, 132.

domus, 194.

dōnec, 288.

Double dative, 91.

Double questions, 221-222.

Doubting, verbs of, 272-273.

dūcō, 122.

Dubitative subjunctive, 218 .

dubitō, 272-273, 329.

dum, while, 285-287; until, 288; in proviso, 290.

Duration of time, $169,452$.

E

efficiō, 264.

egeō, 154.

ègredior, 147-148.

èius modi, $275,4$.

Emotion, verbs of, miseret, etc., 118-120; with indirect discourse, 336.

Emphasis, 401.

Enclitics, 413.

enim, postpositive, 412.

Entreaty, 236; in indirect discourse, 349 .

Envy, verbs of, 79-82.

eō, degree of difference, 161 .

ergā, 112.

et, 394-396.

etiamsī, 322 .

etsī, 322.

excēdō, 147-148. 
E :ceptional sequence, 247-250.

E : clamations, 77.

e: pellō, 147-148.

e? pers, 113-114.

e) spectō, 61 .

E stent, of degree, 74; of space, 199-200; of time, 169.

es.trēmus, 108.

\section{F}

$f=c i \overline{0}$, with double acc., 67-69 ; with gen., 122 .

fáciō ut, 264 .

fє.ctū, 391 .

fє.veō, 79-82.

Favor, verbs of, 79-82.

Fearing, verbs of, 266-268.

ferē, position of, 411 .

fĩdō, 79-82.

Final clauses. Cf. Purpose.

fīnitimus, $92,95$.

fīō, 58 .

fit ut, 264.

fitness, adjectives of, 92-95.

fore ut, 341-342.

Forgetting, verbs of, 116.

:oris, 196.

trētus, 137.

Friendliness, adjectives of, 9295.

Eruor, 165.

Fullness, adjectives of, 113-114. fungor, 165.

Future tense, indicative, 212 ; infinitive, 340-343; participle, 365 .

Future perfect, 213; when changed into subjunctive, 250.

futūrum esse ut, 341-342.

futūrum fuisse ut, 354,3 .
G

gaudeō, 336 .

Gender. Cf. Agreement.

Genitive case, 97-126. description, 101-103.

indefinite value, 122-123.

objective, with nouns, 110-112;

with adjectives, 113-115.

partitive, 104-108.

possession, 97-100.

predicate, 109.

quality, 101-103.

with interest, 124.

with potior, 125.

with similis, etc., 95-96.

with verbs of accusing, etc., 121.

with verbs of emotion, 118-120. with verbs of memory, etc., 116. with verbs of reminding, etc., 117 .

with verbs of rating, 122-123. position of, 409.

Gerund, 376, 378-379, 381, 501.

Gerundive, 377-382, 501.

grātus, 92 .

\section{$\mathrm{H}$}

habeō, with pred. noun, 58; with double acc., 67-69; with gen., 122 .

Helping, verbs of, 79-82.

hīc, haec, hōc, $30,35$.

Hindering, verbs of, 269-271.

Historical perfect, 207.

Historical tenses, 242.

hōc, abl. of degree of difference, 161.

Hoping, verbs of, 334 .

horreō, 60 . 
Hortatory subjunctive, 236, 241; in-, in compounds, with dat., in indirect discourse, 349 ; in conditions, 311.

hortātū, 139.

hortor, 262.

humi, 196.

\section{I}

iam diū, etc., 202, 205.

Ideal conditions, 303-304; in indirect discourse, 353 .

idem, 37.

Ides, 177.

idōneus, 92; idōneus est quī, 275. igitur, 412.

ignōscō, 79-82.

ille, 33-35.

immemor, 113-114.

impediō, 269-270.

Imperative, 237-241; in indirect discourse, 349 ; in conditions, 311.

Imperfect tense, indicative, 203205. subjunctive, 245 .

in wishes, 228.

in conditions, 306 . sequence after, 249.

imperītus, 113-114.

Impersonal construction with verbs of saying, 344-345.

Impersonal use of verbs taking the dative, 82 .

Impersonal verbs, miseret, etc.; 118-119.

imperō, with dat., 79-82; imperō ut, 262.

Implied indirect discourse, 295296.

importō, 475 .

imus, 108.

83 ; with acc., 62 .

incipiō, 329.

Indefinite pronouns and adjectives, 47-56.

Indefinite value, genitive of, 122123.

indigeō, 154.

indignus, 145; indīgnus est, 275, 1.

Indirect discourse, 333-358, 467. commands in, 349.

complex sentences in, 346-358. conditions in, 351-358.

declarative sentences in, 333347.

entreaty in, 349 .

tenses of infinitive in, 337-343. implied or partial, 295-296.

Indirect object, 78-84.

Indirect questions, 251-252;

double, 222; position of, 423.

Indirect reflexive, $21-25,487,541$.

indulgeō, 79-82.

Indulging, verbs of, 79-82.

inferō, 475 .

infēstus, 92.

infimus, 108.

Infinitives, 323-345.

complementary, 329-330.

in indirect discourse, 333-336.

modified by gen. or adj., 100 .

objective, 331-332.

personal and impersonal constructions, 344-345.

subjective, 323-327.

tenses, 337-343, 467.

inimicus, 92,95 .

iniquus, 92.

iniūria, 132.

iniussū, 139.

Inner object, 65-66, 117, 471. 
inops, 113-114.

inter-, in compounds, 83.

interclūdō, 147-148.

Interest, dative of, 87, 91 .

interest, 124.

interficiō, 475 .

Interrogative pronouns, and adjectives, 44-45; position of, 415.

inūtilis, 92-93.

invideō, 79-82.

ipse, 38, 25.

îrāscor, 79-82.

is, ea, id, $36,20,459$.

iste, $31-32$.

iubeō, 332, 263, 81.

iūre, 132.

iūs est ut, 264.

iussū, 139.

iuvō, 81 .

\section{J}

Jussive subjunctive, 236, 241.

\section{K}

Kalends, 177.

Knowing, verbs of, 333 .

Knowledge, adjectives of, 113-114.

L

laetor, with quod, 296; with infinitive, 336 .

laetus, 137.

laevā (parte), 189.

lēge, lēgibus, 132.

Less vivid conditions. Cf. Ideal conditions.

liber, 149.

lïberō, 149.

licet, may, 325, 3, 326; in unreal conditions, 309-310. licet, although, 320 .

Likeness, adjectives of, 92-96.

Limit of motion, 75, 187, 190, 194, 195, 198.

Locative case, 193-198.

locō, locīs, 189.

locō, verb, with in and abl., 191; with gerundive, 382 .

Logical conditions, 301-302; in indirect discourse, 352 .

longius, 159.

lūgeō, with acc., 60; with infinitive, 336 .

\section{M}

maereō, 60.

Making, verbs of, 67-68.

mälim, māllem, 231.

mālō, 329, 332 .

mandō, 262.

manēo, 58.

Manner, ablative of, 131, 463.

Material, ablative of, 152 .

mātūrō, 329.

Means or instrument, ablative of, $127,129,463$.

Measure, genitive of, 102 .

Measure of difference, 160, 162, 200.

medius, 108.

mementō, 239.

meminī, 209-210, 116.

memor, 113-114.

Memory, adjectives of, 113-114; verbs of, 116.

meritō, 132.

metuō, 266-268, 329.

militiae, 196.

mille, mīlia, 494, 3 .

minitor, 79-82.

minor, verb, 79-82. 
minus, adverb, 159. mīror, with acc., 60; with infinitive, 336.

misereor, 120.

miseret, 118-119.

miseror, 120.

Mixed conditions, 308, 311. moneō, 262, 471.

Months, 176-181. mōre, mōribus, 139.

More vivid conditions, $301-302$; in indirect discourse, 352 .

moror, 329.

mōs est ut, 264.

moveō, 147-148.

muitō, 161.

Must, 585.

\section{$\mathrm{N}$}

Naming, verbs of, 58,67 . nātū, 143.

nātus, 150.

nē, in purpose clauses, 254, 265, 262,479 ; after verbs of fearing, 266-267; after verbs of preventing, etc., 269-271; in hortatory subjunctive, 236 , 241 ; in wishes, 226 ; in concessive clauses, 321 .

nè . . . quidem, 412.

-ne, enclitic, 217, 221-222, 413.

Nearness, adjectives of, 92-95.

necesse est, $325,3,326,585$; in unreal conditions, 309-310.

Necessity, verbs of, 309-310.

necne, 222.

Negatives, 265, 479 .

negō, 335.

negōtium dō ut, 262.

nesciō, 329.

Night, divisions of, 175.

nisi, 299, 2.

noceō, 79-82.

nōlī, nōlìte, 240-241.

nōlō, 329, 332.

Nominative case, 57-58.

nōmine, 143.

nōminō, 67-68, 58 .

Nones, 177.

nōnne, 215.

nostrī and nostrum, 17.

nōvī, 209-210.

nūdō, 149.

nūdus, 149.

num, 216.

Number. Cf. Agreement.

Numerals, position of, 406 .

numerō, 143.

\section{$\mathrm{O}$}

ob-, in compounds, 83 .

Obeying, verbs of, 79-82.

Object, direct, 60-63.

indirect, 78-84.

inner, 65-66, 471 .

Objective genitive, 110-112.

Objective infinitive, 331 .

Obligation, in unreal conditions, 309-310, 356.

oblīīscor, 116.

oblitus, 113-114.

obstō, 269-270.

obtineō, 475.

occupō, 475.

òdi, 209-210.

omnis, 189.

oportet, 309-310, 325, 2, 326, 585.

opprimō, 475.

optō, 262.

opus est, 155-156. 
$O \cdot$ der of words, 400-424.

O dinal numerals, position of, 406 .

o dine, 132.

0 :igin, ablative of, 150 .

$\bar{o} \mathbf{0}, 70-72 ; \quad \bar{o} r \bar{o} u t, 262$.

o tus, 150.

Cught, 585 .

\section{$\mathbf{P}$}

p zene, 411.

p) zenitet, 118-119.

pär, 92, 95.

parcō, 79-82.

Pardoning, verbs of, 79-82.

pāreō, 79-82.

parō, with acc., 61; with infinitive, 329 .

parte, partibus, 189.

particeps, 113-114.

Participles, 359-375, 511.

as adjectives, 366 .

as nouns, 367.

for clauses, 375 .

in ablative absolute, 369-374.

in conditions, 312 .

in $-n s$, with gen., 113.

Particles introducing purpose and result clauses, contrasted, 265.

Partitive genitive, 104-108.

Passive periphrastic conjugation, 383-389; in conditions, 309310 .

passus, 494.

patior, 329, 332.

paulō, 161.

per-, in compounds, 62.

per, through the agency of, 130. Perceiving, verbs of, 333.

Perfect tense, indicative, 206209. subjunctive, 244; sequence of, 248 ; in result clauses, 260. infinitive, 339 ; sequence after, 248.

participle, 364 .

perficiō, 264.

Periphrastic conjunctions.

active in indirect questions, 252 ; in conditions, 309-310. passive, $383-389,519$; in conditions, 309-310.

peritus, 113-114.

permittō, 262.

Person, of verb, 8, 11.

Personal and impersonal constructions with verbs of saying, 344-345.

Personal pronouns, 16-20.

persuādeō, with dat., 79-82; with subjunctive, 262.

Persuading, verbs of, 79-82.

pertaesum est, 118-119.

petō, with $\bar{a}$ and abl., 70-72;

with subjunctive, 262 .

piget, 118-119.

Place, constructions of, 186-200. from which, 188, 192, 194, 198. to which, 187, 190, 191, 194, 198.

where, 186, 189, 193-197.

placeō, 79-82.

placet, 325, $1,326$.

Pleasing, verbs of, 79-82.

Plenty, adjectives of, 113-114; verbs of, 153 .

plēnus, 113-114.

Pluperfect tense, indicative, 210, 211.

subjunctive, 246.

in wishes, 229.

in conditions, $307-308$, 
Pluperfect tense, sequence after, 246.

plüs, 159.

polliceor, 334, 471 .

pōnō, 191.

pōscō, 70-72; pōscōo ut, 262.

Possession, genitive of, 97-100; in predicate, 109.

Possessive adjectives, 18, 27-29, 98; position of, 404 .

Possessor, dative of the, 85-86.

Possibility, verbs of, in unreal conditions, 309-310, 356.

possum, with inner object, 66 ; with infinitive, 329 .

future infinitive lacking, 343 .

in unreal conditions, 309-310, 356.

post-, in compounds, 83 .

postpositives, 412.

postquam, 283-284.

postulō, 70-72, 471; postulō ut, 262.

potēns, 113-114.

Potential subjunctive, 232-235.

potior, 165-166, 125.

Power, adjectives of, 113-114; verbs of, 309-310, 356 .

prae-, in compounds, 83.

praecipiō, 262.

praeficiō, 475 .

praeter-, compounds of, 62 .

Predicate adjectives, $1, b, 327$, $330,430$.

Predicate nominative, 57-58.

Predicate nouns, 57-58, 327, 330.

Predicate genitive, 109.

Prepositions, position of, 414.

Present tense, indicative, 201202 ; with dum, 286. subjunctive, 243. in wishes, 227 .

in conditions, 303.

in hortatory subjunctive, 23 infinitive, 338 .

participle, 363.

Preventing, verbs of, 269-271.

Price, ablative of, 163-164.

Primary tenses, 242.

primus, 108.

Principal tenses, 242.

priusquam, 289.

prīvō, 149.

prō-, in compounds, 83.

prōcēdō, 475.

prohibeō, with abl., 147-14 with infinitive, 271, 332 .

Prohibitions, 240-241.

Promising, verbs of, 334 .

prōmittō, 334 .

Pronouns, 12-56.

demonstrative, 30-38.

indefinite, 46-56.

interrogative, 44-45.

personal, 16-20.

reflexive, 19-26.

relative, 12-15, 39-43.

prope, 411.

propior, 94.

Protasis, 298, 302; implied, 312 prōvideō, 262.

Proviso, clauses of, 290.

proximus, 92, 94, 95.

prūdēns, 113-114.

pudet, 118-119.

Pure perfect, 208-209.

Purpose, clauses of, 253-257, 47

position of, 423 ; substanti

clauses of, 261-263.

Purpose, dative of, 90-91, 483. putō, 67-69; with gen. of valu 122. 


\section{Q}

yuaerō, acc. of the thing, 61; abl. of the person, 70-72; with inner object, 471. quality, genitive of, 101-103; in predicate, 109.

ablative of, 140-141. quam, than, omission of, 157-159. quamdiū, 285.

quamquam, 317-318. quamvis, 319.

quandō, 294-295. quantō . . . tantō, 162. quasi, 313.

-que, 413.

queror, with acc., 60; with quod, 296 ; with infinitive, 336 .

Questions, direct, 214-222.

indirect, 251-252, 222.

double, 221-222.

deliberative or dubitative, 218 . rhetorical, 219-220, 235.

position of verb in, 417 .

quī. Cf. Relative.

quia, 294-295.

quīdam, 46, 51 .

quidem, 412 .

quĩlibet, 46,52 .

quīn, 269-272.

quis, quid, indefinite pronoun, 46,48 ; interrogative pronoun, 44-45.

quispiam, 50.

quisquam, 46, 49 .

quisque, 46,54 .

quiviis, 46,52 .

quō, in purpose clauses, 256.

quō . . . hōc (eō), 162.

quoad, $285,288$.

quoniam, 294-295, 297. quōminus, 269-270.

quoque, 412.

R

Rating, verbs of, 122.

Real conditions. Cf. Logical.

Reciprocal pronouns, 26.

recordor, 116.

recūsō, 269-270.

reddō, 67-69.

Reference, dative of, 87, 91 . rëfert, 124.

refertus, 115.

Reflexive pronouns and adjectives, 19-26, 487, 541.

Refusing,' verbs of, 269-271.

Relative clauses.

characteristic, 275-276.

cause, 293.

concession, 316 .

purpose, 255.

result, 259.

Relative adjective, 39-43; position, 403.

Relative pronoun, 39-43; 12-15; position, 415.

Relieving, verbs of, 147-148.

relinquō, 382 .

reliquum est ut, 264.

reliquus, 108.

Remembering, verbs of, 116.

Reminding, verbs of, 117.

reminiscor, 116.

Removing, 147-148.

Resisting, verbs of, 79-82.

resistō, 79-82.

Respect, ablative of, 142-145.

respondeō, 471 .

restat ut, 264.

Result clauses, 258-260, 479; position of, 423. 
Result clauses, substantive clauses, 264-265.

retineō, 269-270.

Rhetorical questions, 219-220, 235. rīdeō, 60 .

rogātū, 139 .

rogō, 70-72; $\operatorname{rog} \bar{o} u t, 262$.

rūs, 194.

\section{$\mathrm{S}$}

Saying, verbs of, 333 .

sciō, 329.

scitō, 239.

Secondary tenses, 242.

sententiā, 139.

sentiō, 471.

Separation, ablative of, 146-149.

Sequence of tenses, 242-250, 448; in result clauses, 260 .

sequitur ut, 264.

Service, dative of, 90-91.

serving, verbs of, 79-82.

serviō, 79-82.

Sharing, adjectives of, 113-114.

Showing, verbs of, 67-68.

sī, 299, 1.

similis, 92, 95-96.

simulatque (simulac), 283.

Simple conditions. Cf. Logical.

sinn, 299, 3.

sinistrā (parte), 189.

sinō, 329, 332, 263.

socius, 113-114.

soleö, 329 .

sōlus est quī, 275.

solvō, 147-148.

Source, ablative of, 150 .

Sparing, verbs of, 79-82.

Special verbs with dative, 79-82. Specification, ablative of, 142$145,463$. spērō, 334.

spoliō, 149.

statuō, 191.

studeō, with dat., 79-82; with infinitive, 329 .

studiōsus, 113-114.

sub-, in compounds, 62 .

Subject, 57; position of, 400; of infinitive, 333 .

Subjunctive mood.

after priusquam and antequam, 289.

after verbs of doubting, 272 .

after verbs of fearing, 266-267.

after verbs of hindering, etc., 269-27.1.

conditions, 303-308.

deliberative, 218.

hortatory, 236, 241.

in causal clauses, 291-296.

in characteristic clauses, 275276.

in concessive clauses, 314-322.

in conditional clauses of comparison, 313.

in indirect discourse, 347-350.

in proviso clauses, 290.

in purpose clauses, 253-257.

in result clauses, 258-260.

in substantive clauses, 261-266.

indirect question, 251-252.

jussive, 236, 241.

potential, 232-235.

rhetorical, 219.

sequence of tenses, 242-250.

wishes, 226-231.

with cum temporal, 278-280.

with dum, 288.

with the impersonal verbs, licet, etc., 325-326.

Subordinate clauses, order of, 423 . 
jubordinate clauses in indirect discourse, $347,350$.

subordination of clauses, 425 . jubstantive clauses, 261-273.

after verbs of doubting, 272273.

after verbs of fearing, 266-268. after verbs of hindering, etc., 269-271.

of purpose, 261-263.

of result, 264-265.

Substantive infinitive, 323-332; modified by gen. or adj., 100. suī, 19-26.

sum, with pred. noun or adj., 58; with gen. of indefinite value, 122; position of, 418 .

summus, 108.

super-, in compounds, 83.

Supines, 390-393.

suus, 19-26.

\section{$\mathrm{T}$}

Table of conditions in indirect discourse, 355 .

taedet, 118-119.

tametsī, 322 .

tamquamsī, 313.

Teaching, verbs of, 70-72.

Temporal clauses, 277-289; position of, 422.

temptō, 329 .

Tendency, clauses of, 274-276. teneō, 269-270.

Tenses, of the indicative, 120-123. present, 201-202.

imperfect, 203-205.

future, 212.

perfect, 206-209.

pluperfect, 210-211.

future perfect, 213 . sequence of tenses, 242-250, 448.

of infinitive, 337-343, 467. of participle, 362-365, 511 .

terrā marique, 189.

Thinking, verbs of, 333 .

Third personal pronouns, $20 \mathrm{ff}$.

Threatening, verbs of, 79-82.

Time constructions, 167-185, 452.

time when, $167,170,452$.

time within which, 168, 452.

time how long, duration of time, 169, 452.

timeō, with subjunctive, 266268 ; with infinitive, 329.

tōtus, 189.

trādō, 382 .

trāns-, in compounds, 62-63.

Trusting, verbs of, 79-82.

Two accusatives, 67-72.

\section{$\mathrm{U}$}

ubi, when, 283.

Unreal conditions, $305-307$; in indirect discourse, 354-355; in dependent clauses, 357; indicative apodosis, 309-310.

ūnus est quī, 275 .

ũsus est, 155.

ut, in purpose clauses, 253 .

in result clauses, 259.

in substantive clauses, 261265.

after verbs of fearing, 266-267.

temporal, 283.

concessive, 321 .

uter, 45.

ūtilis, 92-93.

utinam, 226-230.

ūtor, 165.

utrum ... an, 221-222. 
vacuus, 149 .

valeō, 66 .

-ve, enclitic, 413.

velim, vellem, 231 .

velutsi, 313.

Verbs, syntax of, 201-393; agreement of, 8-11; position of, 400.

vereor, with subjunctive, 226268 ; with infinitive, 329.

vērō, 412.

vēscor, 165.

vester, 18 .

vestri and vestrum, 17 .

vetō, 332, 263.

vī, 132.

videor, with pred. noun or adj., 58 ; with infinitive, 329. videō ut, 262.

vidètur, $325,1$.

vīsū, 391.

Vocative case, 59.

volō, 329, 332 .

voluntāte, 132 .

vulgō, 132.

W

Want, verbs of, 153 .

Wishes, 226-231.

\section{Y}

Year, method of dating, 182-185. 


\section{FIRST BOOK IN LATIN}

iy . LeXander James Inglis, Instructor in Latin, Horace Mann High School, Teachers College, and Virgil Prettyman, Principal Horace Mann High School, Teachers College. Revised Edition. $12 \mathrm{mo}$. Cloth. 301 pages. 90 cents net.

\ series of sixty-five lessons affording an adequate preparation or he reading of Cæsar. The lessons are carefully graded; the ul :, clear and concise.

Without assuming much knowledge of English grammar on the al $t$ of the student, the general principles of inflection and syntax re zradually developed.

'The selection of words for the vocabulary is based on the latest nil most systematic analysis of the vocabulary of the authors sulilly read in our schools. Words have been chosen with particuar attention to their comparative frequency of occurrence, and with special reference to the vocabulary of Cæsar, so that few words ave been admitted which are not of very common occurrence in hat author.

'The exercises consist of three parts: detached Latin sentences; passage of connected Latin; and sentences for translation from inglish into Latin. The detached Latin sentences are intended or practice in the paradigms and syntax of the lesson, while the a isages of connected Latin afford practice in reading narrative atin and review work in vocabulary and syntax.

4 simple system of reference and cross reference is employed so $h$ it any page, paragraph, or footnote may be quickly found. The a adigms presenting the inflections of the various parts of speech ir: found in Appendix I. A summary of rules is given in Ap) $\operatorname{ldix}$ II.

\section{THE MACMILLAN COMPANY Publishers 64-66 Fifth Avenue New York}




\section{MACMILLAN'S LATIN SERIES}

Prepared under the general editorship of J. C. KIRTLAND, Jr., Professor of Latin in the Phillips-Exeter Academy, Exeter, N.H.

Each volume, I2mo. Cloth.

\section{Cornelius Nepos - Twenty Lives}

Edited by J. E. BARss, Latin Master in the Hotchkiss School, Lakeville, Conn. Maps and Illustrations. xiv +316 pages. 90 cents net.

\section{The Poems of Ovid - Selections}

Edited by C. W. BaIN, Professor of Ancient Languages in South Carolina College, and recently Head-master of the Sewanee Grammar School of the University of the South. Illustrations. xiv +46 I pages. \$1.10 net.

\section{Marcus Tullius Cicero-Ten Orations, with the Letters to his Wife}

Edited by R. A. von Minckwitz, De Witt Clinton High School, New York City. Maps and Illustrations. xii +518 pages. \$1.25 net.

\section{IN PREPARATION}

Cæsar - The Gallic War

Edited by A. L. Hodges, Wadleigh High School, New York City.

Vergil - The Eneid

Edited by D. O. S. Lowell and C. W. Gleason, Roxbury Latin School.

Sallust - The Catiline

Edited by J. C. Kirtland, Jr., Phillips-Exeter Academy.

THE MACMILLAN COMPANY

Publishers 64-66 Fifth Avenue New York 


\section{MACMILLAN'S LATIN SERIES}

\section{GENERAL PLAN OF THE SERIES}

The volumes of this series have been prepared by practical teachers who have had actual experience in teaching Latin in secondary schools.

To furnish material for so-called reading at sight, a portion of the text of each author has been printed with only such brief notes as are absolutely necessary to the understanding of the text.

The notes refer to the grammars of Allen and Greenough, Bennett, Gildersleeve and Lodge, Harkness, and Lane and Morgan.

The type is large and clear, generously spaced and leaded; the paper of a dull tint restful to the eyes; the binding firm, but such as to allow the books to open flat. Maps, plans, and illustrations are numerous, and are chosen not for ornament but for real illustration.

\section{Cornelius Nepos}

This edition contains all of the Lives that any teacher will care to have a class read. The Praefatio and thirteen of the Lives have been edited with full notes, the remaining Lives with footnotes for more rapid reading or for sight reading. The vocabulary covers both divisions of the text, and simple word-groups for the study of word-formation.

\section{The Poems of Ovid}

This edition consists of about three thousand verses, with a complete commentary, and about one thousand verses for rapid reading, with brief notes. The selections from the Metamorphoses, which form the greater part of the book, are put first, and are more fully annotated than the selections from the other writings. A brief summary of the general laws of prosody is given in the Introduction, together with copious exercises, and all long vowels are indicated in the earlier selections.

\section{THE MACMILLAN COMPANY}

Publishers

64-66 Fifth Avenue
New York 


\section{Marcus Tullius Cicero}

Ten orations are here presented - the four against Catiline, those on the Manilian Law, for the poet Archias, and for Milo, the Fourteenth Philippic, and those for Marcellus and for Ligarius. The last two orations, together with the fourteenth book of the Epistulae ad Familiares, have been annotated with a view to sight reading, the notes being brief and placed at the corresponding page of Latin text. The orations selected are such as will satisfy the entrance requirements of any college or university in the United States.

The Introduction treats in a comprehensive, clear, and interesting way of the life and character of Cicero ; of the orations presented in this edition; of the letters ; and finally, of the Roman Constitution, with special reference to its bearing upon the subject-matter of the orations.

The Notes are the result of many years of class-room experience. They represent to some extent the need of explanation, as shown by the questions of students in their daily recitations.

\section{Cæsar: The Gallic War}

\section{(Nearly ready.)}

The text will embrace the whole of Cresar's Gallic War, and will be illustrated by maps and cuts in the text and also by a series of general maps in colors. A feature of the map scheme is the fact that all the maps used to show the principal campaigns are drawn on the same scale as the general map of Gaul. The result is that the student, instead of having a confused notion of the character of Cæsar's campaigns, as is caused by the several maps being drawn on entirely different scales, each one different from the other and all different from the general map, secures a very correct and accurate notion of the real extent of country covered by the individual campaigns in their relation to each other. The text will be supplemented by a comprehensive general introduction and also by notes and vocabulary especially prepared for this edition.

\section{THE MAÇMILLAN COMPANY Publishers 64-66 Fifth Avenue New York}




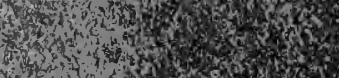

90

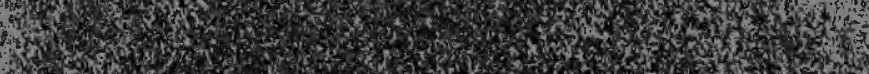

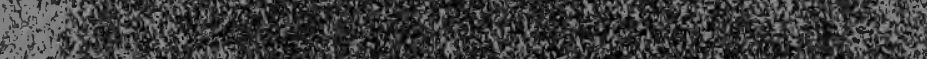
6.

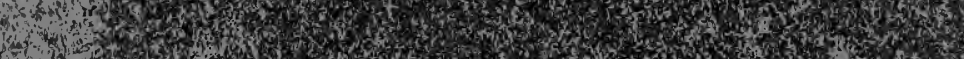

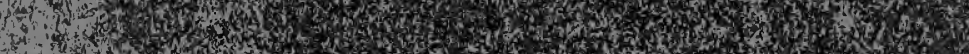

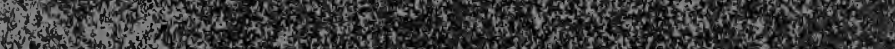
(3) in

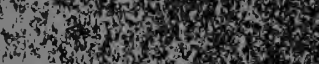

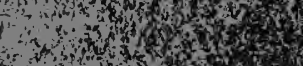

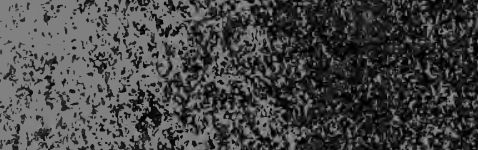

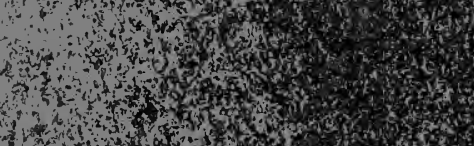

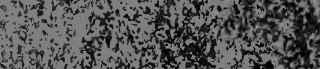

s.

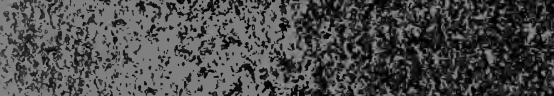

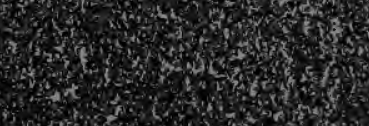

intors

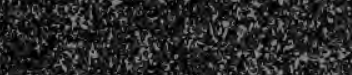

3rof

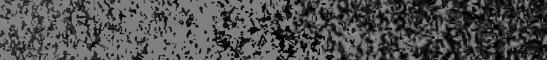

Non

3.

10.8

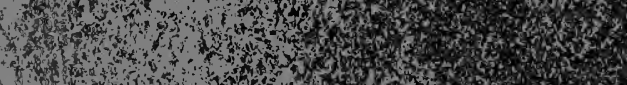

340 .

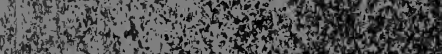

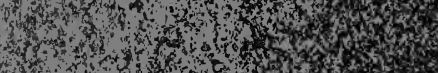

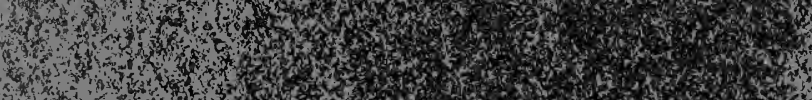

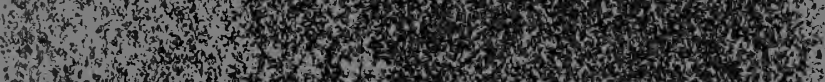

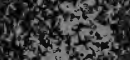

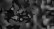
(x) ing fin

3. H.

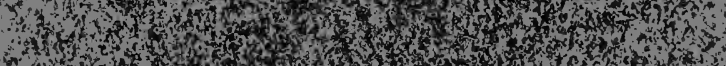

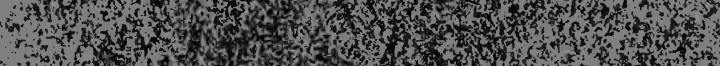

ofis

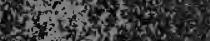
Sintis

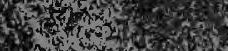

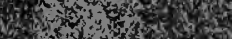

a.

toy $12 x$ wor of
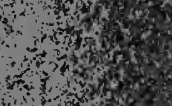

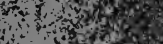

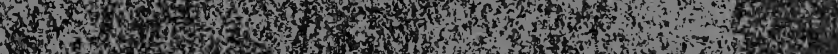

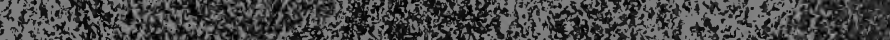

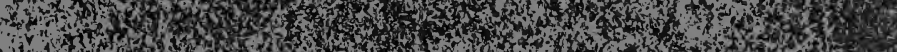

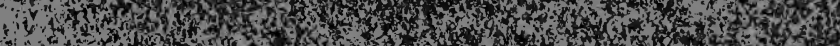

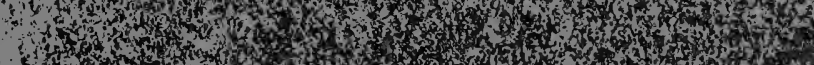

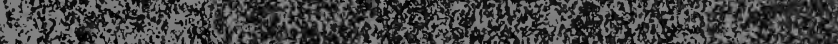

s.

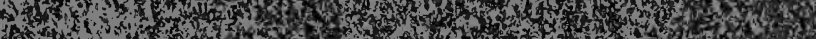

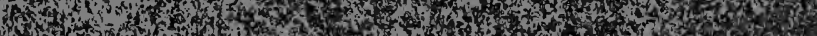

$\because$ Now

0,0 .

-

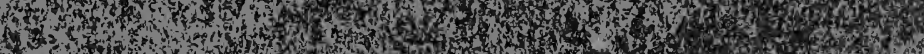

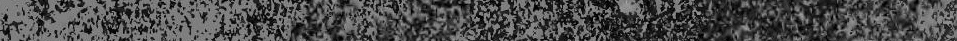

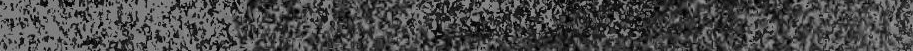

3. In 


\section{UNIVERSITY OF CALIFORNIA LIBRARY}

This book is DUE on the last date stamped below.

Fipeschedale: 25 cents on first day overdue

- 50 cents on fourth day overdue

One dollar on seventh day overdue. 

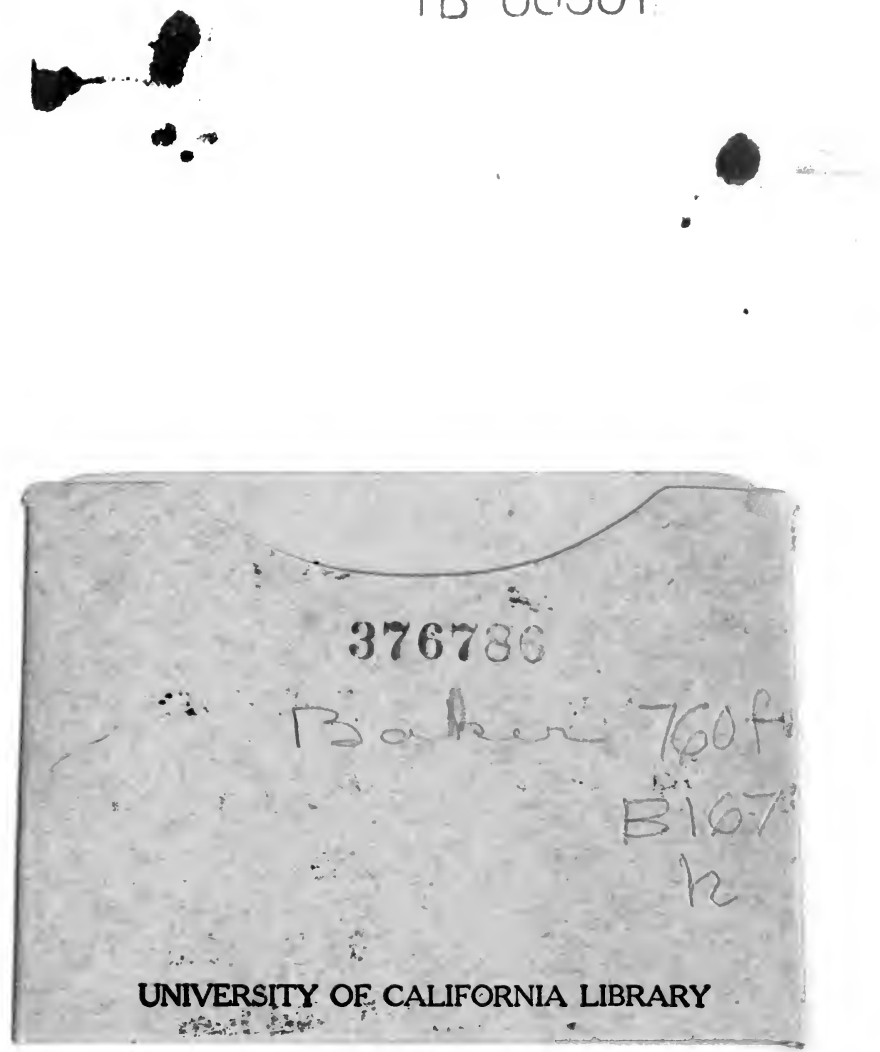
